KLEBERSON RICARDO DE OLIVEIRA PEREIRA

ESTUDO, EM ESCALA DE LABORATÓRIO, DO USO DE ARGILAS DO TIPO BOFE NA OBTENÇÃO DE ARGILAS ORGANOFÍLICAS

E ATIVADAS

São Paulo - SP

2008 
KLEBERSON RICARDO DE OLIVEIRA PEREIRA

\section{ESTUDO, EM ESCALA DE LABORATÓRIO, DO USO DE ARGILAS DO TIPO BOFE NA OBTENÇÃO DE ARGILAS ORGANOFÍLICAS \\ E ATIVADAS}

Tese apresentada à Escola Politécnica da Universidade de São Paulo para obtenção do título de Doutor em Engenharia.

Área de concentração:

Engenharia Metalúrgica e de Materiais

Orientador:

Prof. Dr. Francisco Rolando Valenzuela Díaz

$$
\begin{gathered}
\text { São Paulo - SP } \\
2008
\end{gathered}
$$


Este exemplar foi revisado e alterado em relação à versão original, sob responsabilidade única do autor e com a anuência de seu orientador.

São Paulo, de abril de 2008.

Assinatura do autor

Assinatura do orientador

FICHA CATALOGRÁFICA

Pereira, Kleberson Ricardo de Oliveira

Estudo, em escala de laboratório, do uso de argilas do tipo

Bofe na obtenção de argilas organofílicas e ativadas / K.R.O.

Pereira. -- ed.rev. -- São Paulo, 2008. $139 \mathrm{p}$.

Tese (Doutorado) - Escola Politécnica da Universidade de São Paulo. Departamento de Engenharia Metalúrgica e de Materiais.

1.Argilas (Características; Aplicações 2.Argilas (Tratamento químico) 3.Argilas organofílicas 4. Argilas ativadas I.Universidade de São Paulo. Escola Politécnica. Departamento de Engenharia Metalúrgica e de Materiais II.t. 
A meus pais Ednaldo e Dalva

À minha esposa Zedna

À minha filha Alícia 
"Ser suficiente artista é ter capacidade de desenhar a imaginação. $A$ imaginação é mais importante que o conhecimento. O conhecimento é limitado. A imaginação envolve ao mundo". 
A Deus, por caminhar sempre ao meu lado, por me dar força e perseverança.

Ao meu orientador, Prof. Dr. Francisco Rolando Valenzuela Díaz, pela confiança e incentivo na realização deste trabalho, pela amizade, apoio e compreensão durante toda a fase de desenvolvimento da pesquisa, que além de orientador é um grande amigo.

A Prof. ${ }^{-}$Dr. $\stackrel{a}{ }$ Meiry Gláucia Freire Rodrigues, pelo carinho e amizade, sempre dedicada a ajudar, pelos grandes trabalhos em equipe e sem a qual não estaria onde estou.

Aos professores do Laboratório de Matérias-Primas Particuladas e Sólidos Não Metálicos (LMPSol): Prof. Dr. Antônio Carlos Vieira Coelho, Prof. Dr. Pérsio de Souza Santos, Prof. Dr. Samuel Toffoli, Prof. Dr. Hélio Wiebeck e Prof. Dr. Pedro Maurício Büchler.

Ao anterior e atual coordenador do curso de Pós-Graduação em Engenharia Metalúrgica e de Materiais, Prof. Dr. Jorge Alberto Tenório e Prof. Dr. Douglas Gôuvea e ao secretário Franklin Espíndola, pelo profissionalismo e dedicação aos alunos.

A Comissão de Pós-Graduação da Escola Politécnica da Universidade de São Paulo (EPUSP).

Aos professores do Departamento de Engenharia Metalúrgica e de Materiais (PMT), que transmitiram seus conhecimentos nas disciplinas cursadas.

A minha família: meus pais, Ednaldo e Dalva e meus irmãos, Paula e Tiago, que estão sempre ao meu lado, nunca medindo esforços para me ajudar.

A minha esposa Zedna e minha filha Alícia, pela paciência e por compreenderem os momentos de ausência.

A Zélia, Odílio e Ziane, que dão apoio familiar e torcem pelo meu sucesso. 
Aos eternos amigos, Renato Mariano, Lucimar Pacheco, Andréa Silva, Alfredina Araújo, Rucilana Cabral e tantos outros, que mesmo distantes sempre valorizaram a verdadeira amizade.

Aos amigos aqui conquistados, Carolina Pinto, Alexandre Machado, Marilda Vianna, Ricardo Yoshimitsu, Kelly Nanci, Kilça Tanaka, Claudete Kallas, Adriana Fraiha, Nelma Albanez, Herney Franco, Emerson Barreto, Priscila Anadão, Sérgio Forini, Shirley Cosin e Guillermo Cortés, que sempre serão especiais e já fazem parte da minha vida.

Aos técnicos do LMPSol, Valquíria Kozievitch e Wilson Maia, pela amizade e grande contribuição.

A todos que fazem o Laboratório de Matérias-Primas Particuladas e Sólidos Não Metálicos (LMPSol/PMT/EPUSP), alunos de graduação e pós-graduação, pelo convívio e amizade.

A todos que fazem o Laboratório de Novos Materiais (LABNOV/UAEQ) da Universidade Federal de Campina Grande (UFCG), coordenado pela Prof. ${ }^{a}$ Dr.. a Meiry Gláucia Freire Rodrigues, a Bianca Sousa e a Simone Gallani, pela amizade e trabalhos em equipe e demais alunos de graduação e pós-graduação.

Ao Laboratório de Processos Cerâmicos (LPC/PMT/EPUSP), nas pessoas do Prof. Dr. Douglas Gôuvea e Dr. Gilberto Pereira; Laboratório de Microscopia Eletrônica e de Força Atômica (LabMicro/PMT/EPUSP), nas pessoas do Prof. Dr. André Paulo Tschiptschin, Dr. ํㅡㅁ Marina Magnani e Vinícius Freire; Laboratório de Fotoquímica (PQI/EPUSP), na pessoa do Prof. Dr. Antônio Carlos Silva Costa Teixeira.

Ao CNPq pelo auxílio financeiro.

A todos que direta ou indiretamente contribuíram na realização desta pesquisa. 


\section{RESUMO}

Este trabalho apresenta o desenvolvimento da tese intitulada: Estudo, em escala de laboratório, do uso de argilas do tipo Bofe na obtenção de argilas organofílicas e ativadas. Argilas do tipo esmectítico são as de maior utilização industrial, sendo considerada a mais interessante das argilas industriais. Todavia em diversos casos faz-se necessário submetê-las a tratamentos químicos para desenvolver suas potencialidades. Para o desenvolvimento da tese foram utilizadas quatro amostras de argilas do tipo Bofe, provenientes de jazidas localizadas no município de Boa Vista, PB. Esse tipo de argila, apesar de ser bastante abundante, possui baixo valor econômico dada a dificuldade de obter produtos com propriedades adequadas a partir delas. Neste estudo utilizamos dois tipos de tratamentos, para verificar a potencialidade destas argilas, que foram: ativação ácida e organofilização. Para ativação ácida, foi utilizado o ácido clorídrico com diferentes tempos de reação, variando de uma hora até sete dias e com estas amostras avaliou-se o poder descorante em óleo de soja. Para a organofilização foram utilizados três sais quaternários de amônio e com as argilas organofílicas obtidas realizou-se teste de sorção em solventes orgânicos. Os resultados obtidos indicam que o tratamento ácido em argilas, com tempos de reação muito longos, promove destruição significativa da estrutura do argilomineral esmectítico. As argilas na sua forma natural apresentaram, no descoramento de óleo de soja, comportamento superior ao de argilas industriais ativadas de alto desempenho o que potencializa o uso das argilas tipo Bofe como materiais descorantes naturais (terras fuller). Em relação à organofilização, observou-se a eficiência no tratamento aplicado, visto o aumento do espaçamento interplanar, medido por difração de raios- $X$ e da alta capacidade de sorção de óleo Diesel e Tolueno dos materiais organofílicos obtidos.

Palavras-chave: argila esmectítica, ativação ácida, organofilização. 


\begin{abstract}
This work present the development of the entitled thesis: Study, at laboratory scale, of the use of the Bofe type clay to obtain organophillic and activated clays. Clays of the smectite type are of the bigger industrial use, being considered most interesting of the clay minerals. However, becomes necessary to submit it to chemical treatments for develop its potentialities. For the development of the research four samples of clay from the Bofe type had been used, proceeding from deposits located in areas near to the city of Boa Vista, PB. This type of clays, in spite of they be quite abundant, possess low economic value because the difficulty to obtain products with adequate properties starting from them. In this study to verify the potentiality of these clays we used two types of treatments. Those treatments were: acid activation and organophillic modification. For the acid activation treatment, hydrochloric acid was used with different times of reaction, varying from one hour up to seven days and with the obtained samples the fade power was evaluated in soy oil. To the organophillic modification treatment three quaternary ammonium salts were used. With the samples of the treated clays were made sorption in organic solvents tests. The obtained results indicate that the acid treatment in clays, with very long times of reaction, promotes significant destruction of the structure of the smectite clay mineral. Clays in its natural form presented, in the soy oil fade, superior behavior to the one of industrial activated clays of high performance, that indicates the potential of use of the type Bofe clays as natural bleacher material (fuller's earth). In relation to the organophillic modification, it was observed efficiency in the applied treatment, seen the increase of the interplane spacing, measured by $X$ ray diffraction and the high capacity of sorption of Diesel oil and Toluene of the gotten organophillic materials indicating its potential of use in the sorption of hydrocarbons.
\end{abstract}

Key-Words: smectite clay, acid treatment, organophillic modification. 


\section{SUMÁRIO}

Lista de Tabelas

Lista de Figuras

\section{Capítulo 1 - Introdução}

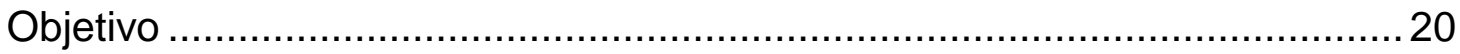

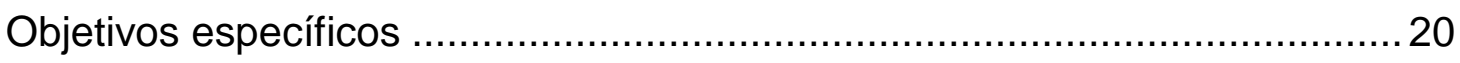

\section{Capítulo 2 - Revisão de literatura}

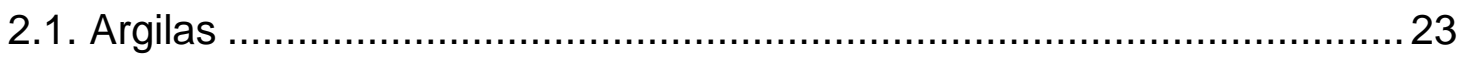

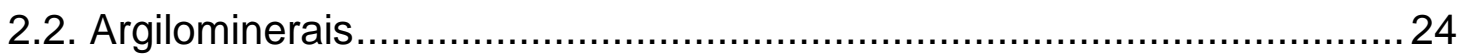

2.2.1. Propriedades dos principais argilominerais ................................... 25

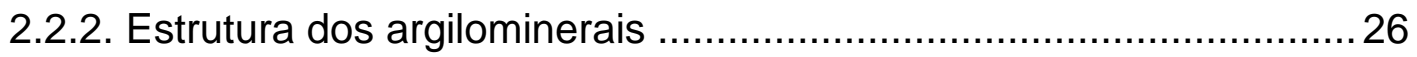

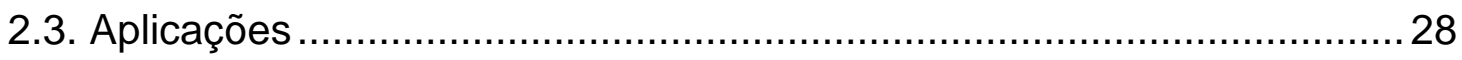

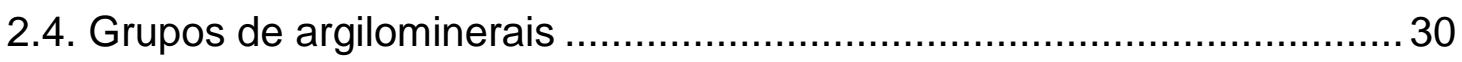

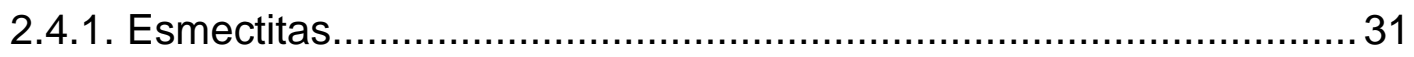

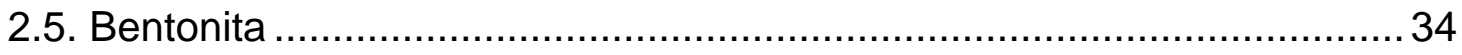

2.5.1. Bentonitas que incham e que não incham em água ........................36

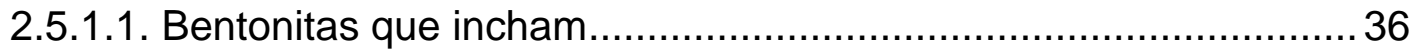

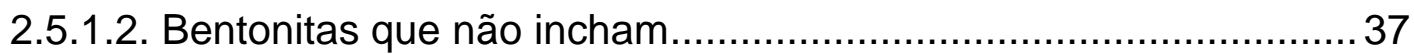

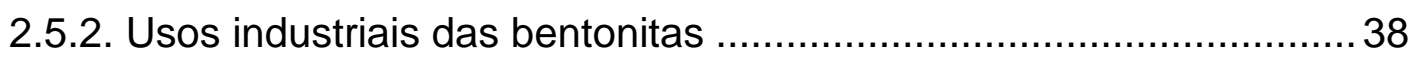

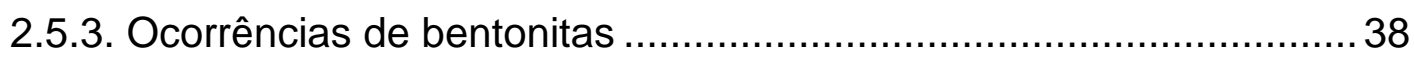

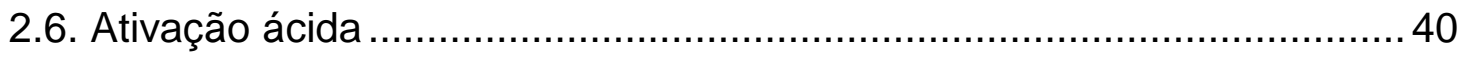

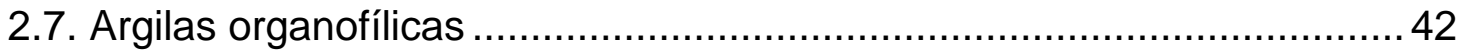

\section{Capítulo 3 - Materiais e Métodos}

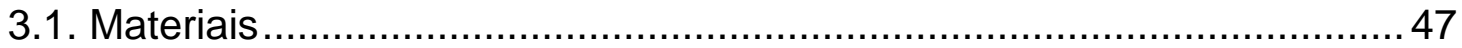

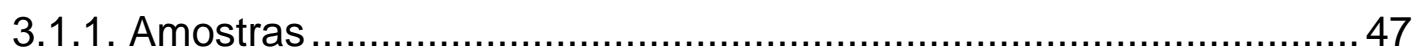

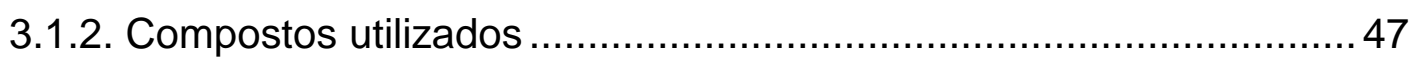

3.2. Determinação da capacidade de troca de cátions (CTC) .......................48

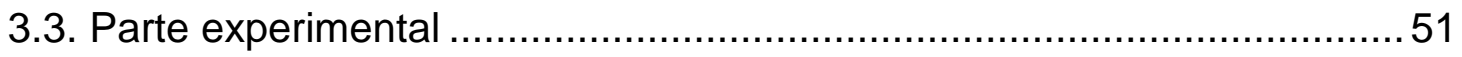

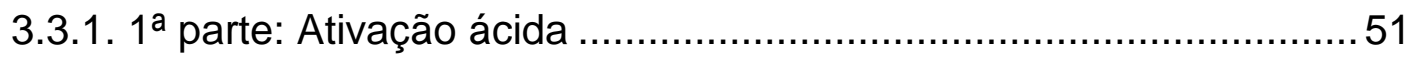

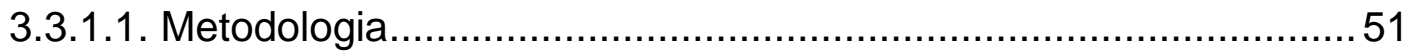

3.3.1.2. Teste de descoramento de óleo................................................53

3.3.2. $2^{a}$ parte: Preparação de argilas organofílicas ...................................54 
3.3.2.1. Metodologia .54

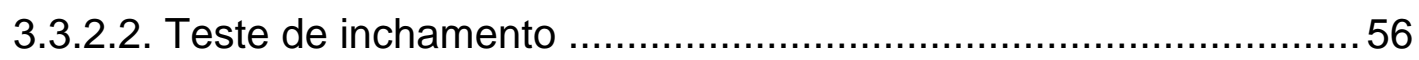

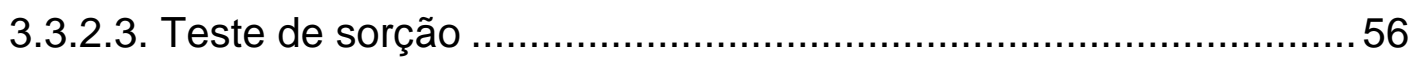

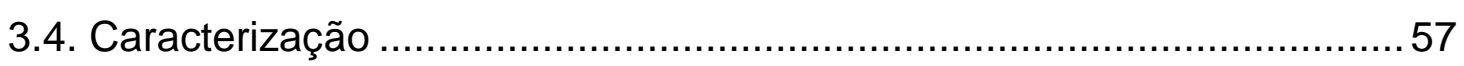

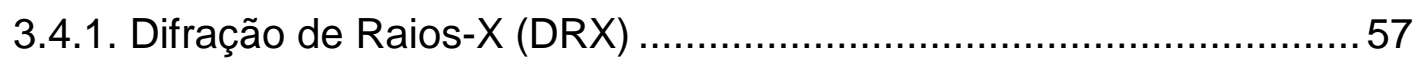

3.4.2. Espectroscopia na Região do Infravermelho (FTIR) ......................58

3.4.3. Análises Térmicas: TG, DTG e DTA ……….................................58

3.4.4. Microscopia Eletrônica de Varredura (MEV) …………………..... 59

\section{Capítulo 4 - Resultados e discussões - Argilas naturais}

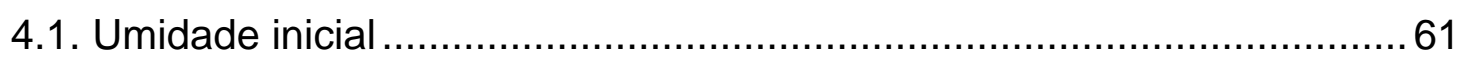

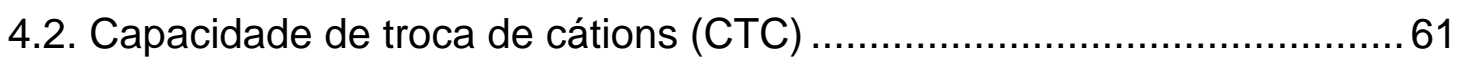

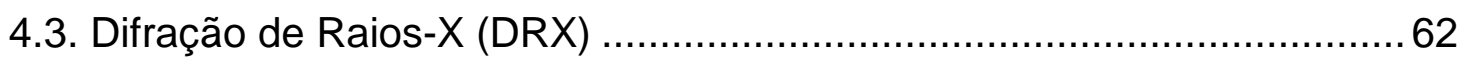

4.4. Espectroscopia na Região do Infravermelho (FTIR) ............................. 65

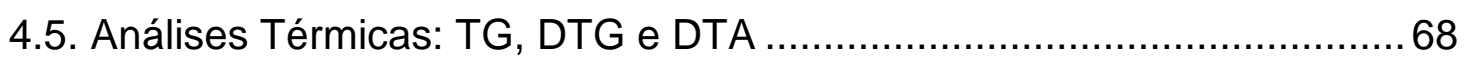

4.6. Microscopia Eletrônica de Varredura (MEV) ……….......................... 71

\section{Capítulo 5 - Resultados e discussões - Ativação ácida}

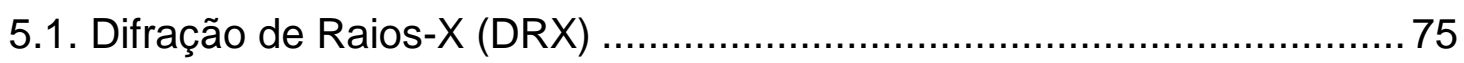

5.2. Espectroscopia na Região do Infravermelho (FTIR) …………............. 80

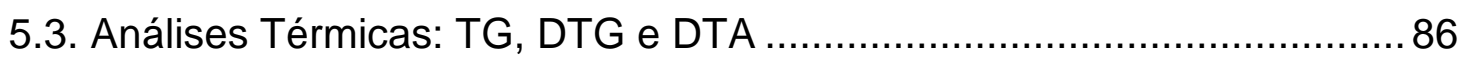

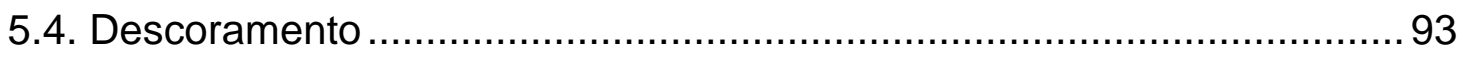

\section{Capítulo 6 - Resultados e discussões - Argilas organofílicas}

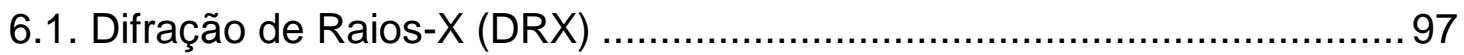

6.2. Espectroscopia na Região do Infravermelho (FTIR) .............................. 101

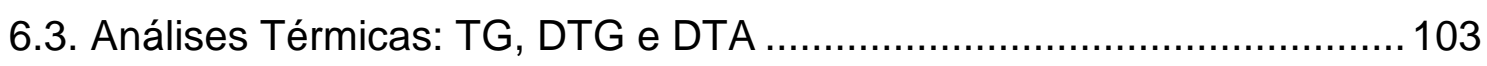

6.4. Microscopia Eletrônica de Varredura (MEV) ………............................ 111

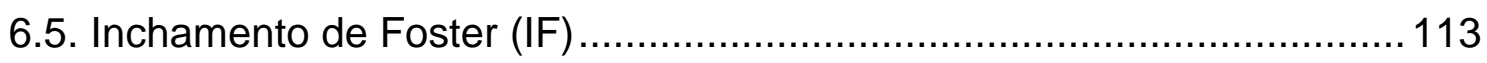

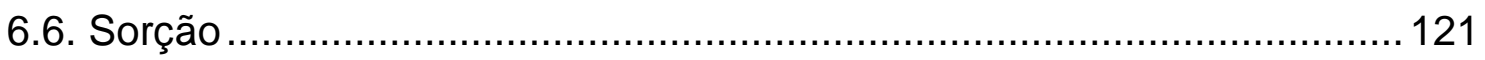

\section{Capítulo 7 - Considerações finais}

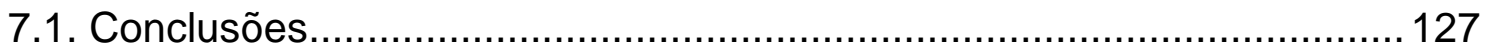

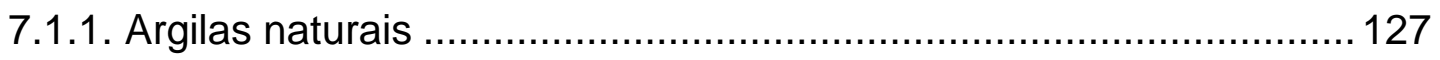

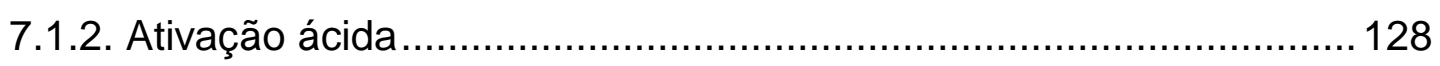

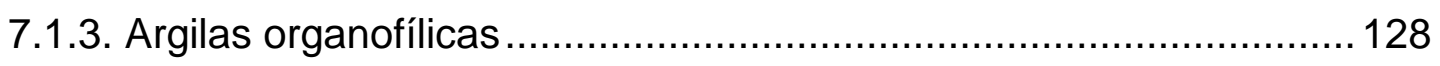

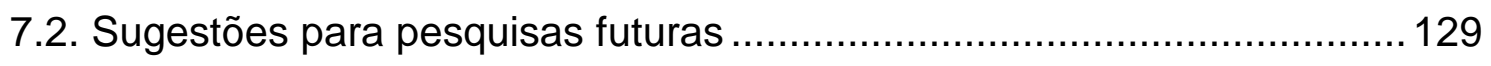

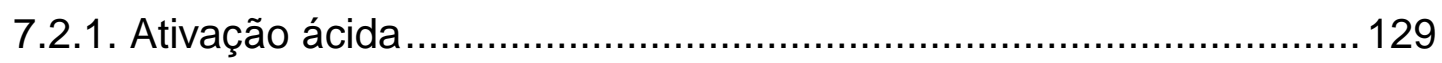


7.2.2. Argilas organofílicas

130

Capítulo 8 - Referências

Referências bibliográficas ................................................................. 132 


\section{LISTA DE TABELAS}

Tabela 2.2.1 - Análise química de argilas típicas ...........................................25

Tabela 2.5.3.1 - Reserva e produção mundial.................................................... 39

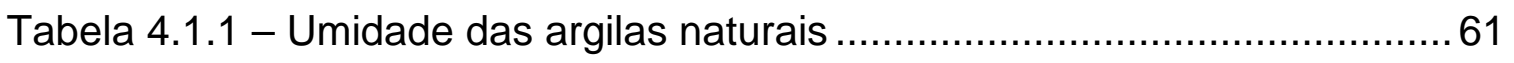

Tabela 4.2.1 - Capacidade de troca de cátions (CTC) das argilas naturais ......62

Tabela 4.5.1 - Perdas de massa total das amostras A, B, C e D ...................... 71

Tabela 5.1.1 - Distâncias interlamelares das amostras A, B, C e D ativadas com tempos de reação de 1, 2 e 3 horas .......................................................

Tabela 5.3.1 - Perdas de massa total das argilas ativadas A, B, C e D, com

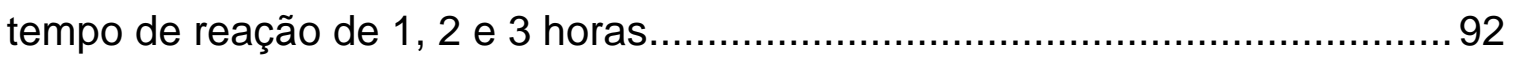

Tabela 5.4.1 - Porcentagem de descoramento de óleo de soja das amostras naturais e comerciais

Tabela 5.4.2 - Porcentagem de descoramento de óleo de soja das amostras A, B, C e D ativadas com os tempos de reação de 1, 2 e 3 horas ......93

Tabela 6.3.1 - Perdas de massa total das argilas organofílicas A, B, C e D obtidas com os sais quaternários 1,2 e 3

Tabela 6.5.1 - Considerações adotadas no LMPSol para o teste de inchamento de Foster. 


\section{LISTA DE FIGURAS}

Figura 1.1 - Localização aproximada da cidade de Boa Vista - PB 20

Figura 2.2.2.1 - a. Tetraedro de $\mathrm{SiO}_{4}$; b. folha de tetraedros (os tetraedros de $\mathrm{SiO}_{4}$ associam-se em arranjos hexagonais); c. octaedro em que o átomo coordenado pode ser Al, Fe ou Mg; d. folha de octaedros.

Figura 2.2.2.2 - Representação esquemática do agrupamento das folhas de tetraedros e octaedros.

Figura 2.4.1.1 - Diagrama esquemático da estrutura cristalina das esmectitas

Figura 2.4.1.2 - Representação do espaço interlamelar e da distância basal das argilas esmectíticas

Figura 2.5.1 - Estrutura cristalina da bentonita

Figura 2.7.1 - Representação do cátion do sal quaternário de amônio na estrutura da bentonita.

Figura 2.7.2 - Arranjo dos cátions orgânicos na região interlamelar das argilas organofílicas: (a) monocamada, (b) bicamada, (c) camada pseudotrimolecular e (d) complexo parafínico ..................................................4 44

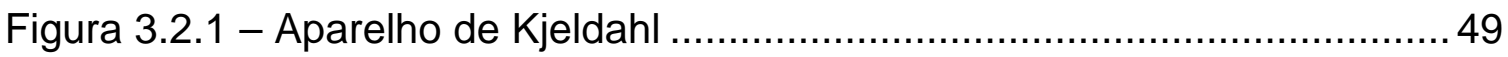

Figura 3.2.2 - Esquema de destilação de Kjeldahl .........................................50

Figura 3.3.1.1.1 - Fluxograma da metodologia da ativação ácida .....................52

Figura 3.3.2.1.1 - Fluxograma de preparação de argilas organofílicas..............55

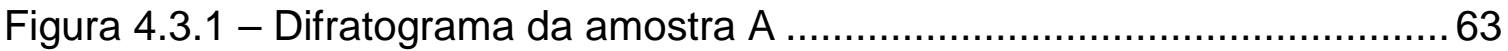

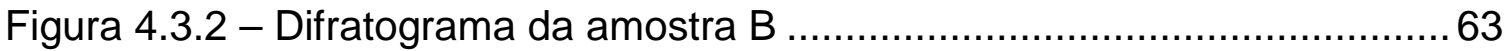

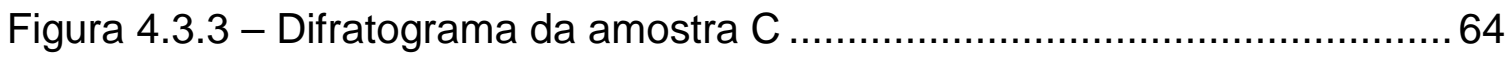

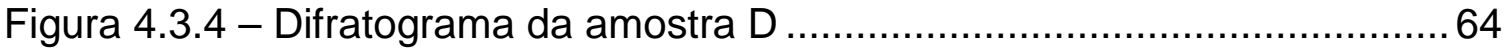

Figura 4.4.1 - Espectroscopia na região do infravermelho da amostra A ..........66

Figura 4.4.2 - Espectroscopia na região do infravermelho da amostra B..........66

Figura 4.4.3 - Espectroscopia na região do infravermelho da amostra C..........67

Figura 4.4.4 - Espectroscopia na região do infravermelho da amostra D..........67 
Figura 4.5.1 - Curvas TG, DTG e DTA da amostra A …..................................

Figura 4.5.2 - Curvas TG, DTG e DTA da amostra B ....................................69

Figura 4.5.3 - Curvas TG, DTG e DTA da amostra C ................................... 70

Figura 4.5.4 - Curvas TG, DTG e DTA da amostra D...................................70

Figura 4.6.1 - Micrografias da amostra A.................................................. 71

Figura 4.6.2 - Micrografias da amostra B................................................. 72

Figura 4.6.3 - Micrografias da amostra C …………….............................. 72

Figura 4.6.4 - Micrografias da amostra D ……………............................... 72

Figura 5.1.1 - Difratogramas das amostras A, B, C e D ativadas com ácido

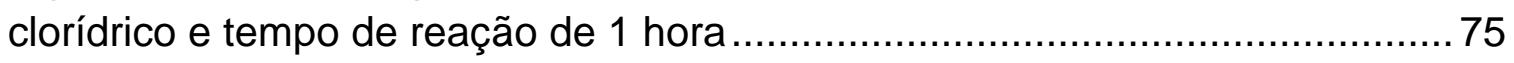

Figura 5.1.2 - Difratogramas das amostras A, B, C e D ativadas com ácido clorídrico e tempo de reação de 2 horas ........................................................... 76

Figura 5.1.3 - Difratogramas das amostras A, B, C e D ativadas com ácido clorídrico e tempo de reação de 3 horas ......................................................... 76

Figura 5.1.4 - Difratogramas da amostra A ativada com ácido clorídrico e tempo de reação de 1, 2, 3, 4, 5, 6 e 7 dias

Figura 5.1.5 - Difratogramas da amostra B ativada com ácido clorídrico e tempo de reação de 1, 2, 3, 4, 5, 6 e 7 dias

Figura 5.1.6 - Difratogramas da amostra $C$ ativada com ácido clorídrico e tempo de reação de $1,2,3,4,5,6$ e 7 dias

Figura 5.1.7 - Difratogramas da amostra D ativada com ácido clorídrico e tempo de reação de 1, 2, 3, 4, 5, 6 e 7 dias

Figura 5.2.1 - Espectroscopia na região do infravermelho das amostras A,

$\mathrm{B}, \mathrm{C}$ e D ativadas com tempo de reação de 1 hora.

Figura 5.2.2 - Espectroscopia na região do infravermelho das amostras A,

$\mathrm{B}, \mathrm{C}$ e D ativadas com tempo de reação de 2 horas

Figura 5.2.3 - Espectroscopia na região do infravermelho das amostras A, $\mathrm{B}, \mathrm{C}$ e D ativadas com tempo de reação de 3 horas

Figura 5.2.4 - Espectroscopia na região do infravermelho das amostras A, B, C e D ativadas com tempo de reação de 1 dia

Figura 5.2.5 - Espectroscopia na região do infravermelho das amostras A,

$\mathrm{B}, \mathrm{C}$ e $\mathrm{D}$ ativadas com tempo de reação de 2 dias 
Figura 5.2.6 - Espectroscopia na região do infravermelho das amostras A, $\mathrm{B}, \mathrm{C}$ e D ativadas com tempo de reação de 3 dias

Figura 5.2.7 - Espectroscopia na região do infravermelho das amostras A, B, C e D ativadas com tempo de reação de 4 dias

Figura 5.2.8 - Espectroscopia na região do infravermelho das amostras A, $\mathrm{B}, \mathrm{C}$ e $\mathrm{D}$ ativadas com tempo de reação de 5 dias

Figura 5.2.9 - Espectroscopia na região do infravermelho das amostras A, B, C e D ativadas com tempo de reação de 6 dias

Figura 5.2.10 - Espectroscopia na região do infravermelho das amostras A,

$\mathrm{B}, \mathrm{C}$ e D ativadas com tempo de reação de 7 dias

Figura 5.3.1 - Curvas TG, DTG e DTA da amostra A, ativada com tempo de reação de 1 hora

Figura 5.3.2 - Curvas TG, DTG e DTA da amostra B, ativada com tempo de reação de 1 hora

Figura 5.3.3 - Curvas TG, DTG e DTA da amostra C, ativada com tempo de reação de 1 hora

Figura 5.3.4 - Curvas TG, DTG e DTA da amostra D, ativada com tempo de reação de 1 hora

Figura 5.3.5 - Curvas TG, DTG e DTA da amostra A, ativada com tempo de reação de 2 horas.

Figura 5.3.6 - Curvas TG, DTG e DTA da amostra B, ativada com tempo de reação de 2 horas.

Figura 5.3.7 - Curvas TG, DTG e DTA da amostra C, ativada com tempo de reação de 2 horas.

Figura 5.3.8 - Curvas TG, DTG e DTA da amostra D, ativada com tempo de reação de 2 horas.

Figura 5.3.9 - Curvas TG, DTG e DTA da amostra A, ativada com tempo de reação de 3 horas.

Figura 5.3.10 - Curvas TG, DTG e DTA da amostra B, ativada com tempo de reação de 3 horas.

Figura 5.3.11 - Curvas TG, DTG e DTA da amostra C, ativada com tempo de reação de 3 horas.

Figura 5.3.12 - Curvas TG, DTG e DTA da amostra D, ativada com tempo de reação de 3 horas 
Figura 6.1.1 - Difratogramas das amostras A, B, C e D tratadas com sal quaternário 1

Figura 6.1.2 - Difratogramas das amostras A, B, C e D tratadas com sal quaternário 2

Figura 6.1.3 - Difratogramas das amostras A, B, C e D tratadas com sal quaternário 3

Figura 6.2.1 - Espectros na região do infravermelho das amostras A, B, C e $\mathrm{D}$ tratadas com sal quaternário 1

Figura 6.2.2 - Espectros na região do infravermelho das amostras A, B, C e

D tratadas com sal quaternário 2 102

Figura 6.2.3 - Espectros na região do infravermelho das amostras A, B, C e D tratadas com sal quaternário 3

Figura 6.3.1 - Curvas TG, DTG e DTA da amostra A tratada com o sal quaternário 1

Figura 6.3.2 - Curvas TG, DTG e DTA da amostra B tratada com o sal quaternário 1

Figura 6.3.3 - Curvas TG, DTG e DTA da amostra C tratada com o sal quaternário 1

Figura 6.3.4 - Curvas TG, DTG e DTA da amostra D tratada com o sal quaternário 1

Figura 6.3.5 - Curvas TG, DTG e DTA da amostra A tratada com o sal quaternário 2

Figura 6.3.6 - Curvas TG, DTG e DTA da amostra B tratada com o sal quaternário 2

Figura 6.3.7 - Curvas TG, DTG e DTA da amostra C tratada com o sal quaternário 2

Figura 6.3.8 - Curvas TG, DTG e DTA da amostra D tratada com o sal quaternário 2

Figura 6.3.9 - Curvas TG, DTG e DTA da amostra A tratada com o sal quaternário 3

Figura 6.3.10 - Curvas TG, DTG e DTA da amostra B tratada com o sal quaternário 3

Figura 6.3.11 - Curvas TG, DTG e DTA da amostra C tratada com o sal quaternário 3 
Figura 6.3.12 - Curvas TG, DTG e DTA da amostra D tratada com o sal quaternário 3

Figura 6.4.1 - Micrografias das amostras A, B, C e D, obtidas com sal quaternário 1

Figura 6.4.2 - Micrografias das amostras A, B, C e D, obtidas com sal quaternário 2

Fig. 6.5.1 - Inchamento de Foster, sem agitação, das amostras A, B, C e D tratadas com o sal quaternário 1

Figura 6.5.2 - Inchamento de Foster, com agitação, das amostras A, B, C e

$\mathrm{D}$ tratadas com o sal quaternário 1

Figura 6.5.3 - Inchamento de Foster, sem agitação, das amostras A, B, C e D tratadas com o sal quaternário 2

Figura 6.5.4 - Inchamento de Foster, com agitação, das amostras A, B, C e $\mathrm{D}$ tratadas com o sal quaternário 2

Figura 6.5.5 - Inchamento de Foster, sem agitação, das amostras A, B, C e $\mathrm{D}$ tratadas com o sal quaternário 3

Figura 6.5.6 - Inchamento de Foster, com agitação, das amostras A, B, C e D tratadas com o sal quaternário 3

Figura 6.6.1 - Sorção das amostras A, B, C e D tratadas com o sal quaternário 1

Figura 6.6.2 - Sorção das amostras A, B, C e D tratadas com o sal quaternário 2

Figura 6.6.3 - Sorção das amostras A, B, C e D tratadas com o sal quaternário 3 
argilasativaçãoquímica organotiliza ãoesmectíticasbentonitasestudoácic adescoramentosorventeshidrocarbs
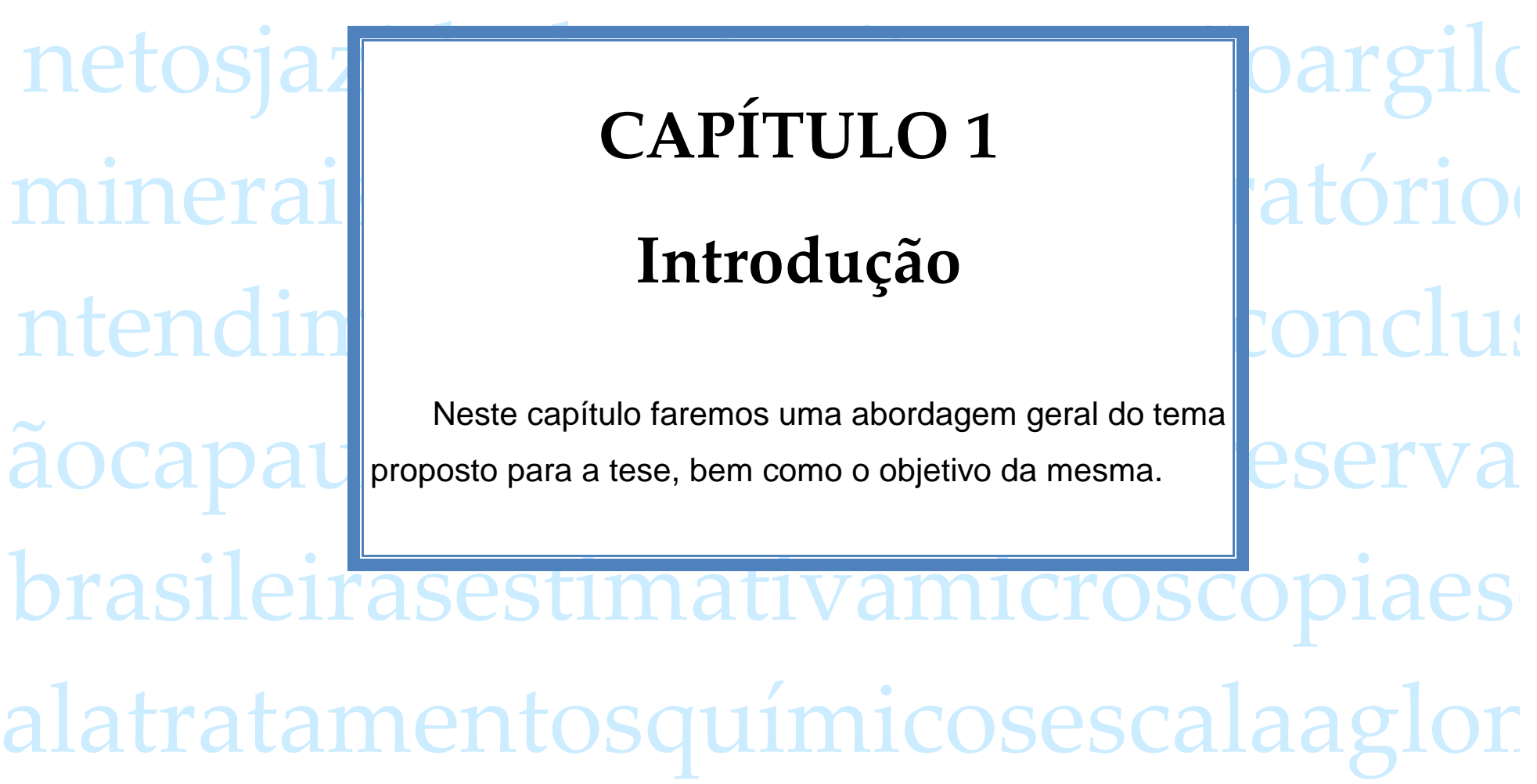
eradoslocalizadasreaçãotempossai: quaternáriosespectroscopiadescorc mentoorganofílicastabelasgráficosin etodologiaresultadosativaçãobofer alizaçãoteseartigosespectrofotomet agasolina clorídricolaboratórioutiliz çãoindústrialcientíficociênciab ofeo 
A evolução humana tem sido limitada ao uso de materiais disponíveis. A argila é um destes materiais e vem sendo utilizada há milhares de anos, principalmente na produção de produtos estruturais como tijolos e telhas. É uma das substâncias naturais de interesse industrial da maior importância e variados produtos se fazem com elas ou com a ajuda delas, assim, a utilização das argilas na indústria é de grande valor econômico.

Bentonitas (argilas esmectíticas) são amplamente utilizadas na indústria, sendo que suas aplicações estão associadas à sua capacidade como adsorventes e espessantes e estas propriedades podem ser incrementadas por tratamentos térmicos e químicos.

A importância destas argilas está refletida no seu largo uso em aplicações industriais e ambientais. Alguns exemplos são: a) como agente tixotrópico para perfuração rotativa de poços; b) agente aglomerante de areia de moldagem para fundição; c) em engenharia civil; d) como agente descorante de óleos vegetais, animais e minerais; e) na obtenção de argilas organofílicas; entre diversas outras aplicações.

A abundância e o baixo custo das argilas naturais, agregados ao potencial que elas representam, principalmente quando modificadas, resultam em atração científica e industrial.

O Estado da Paraíba é um importante produtor de bentonitas. As principais argilas lavradas atualmente são denominadas por cores, sendo as principais a Chocolate e a Verde Lodo. Essas argilas estão com as suas jazidas no início do processo de exaustão, prevendo-se tempos de uso variando de 5 a 10 anos. Associados aos depósitos dessas argilas (camadas adjacentes) há um tipo de argilas denominadas de Bofe, que são provenientes da cidade de Boa Vista-PB (localização aproximada apresentada na Figura 1.1), as quais existem em grandes quantidades e que mesmo tendo sido caracterizadas como argilas esmectíticas não têm encontrado amplo uso industrial, servindo basicamente como inertes de misturas de diversos produtos à base de bentonitas. 


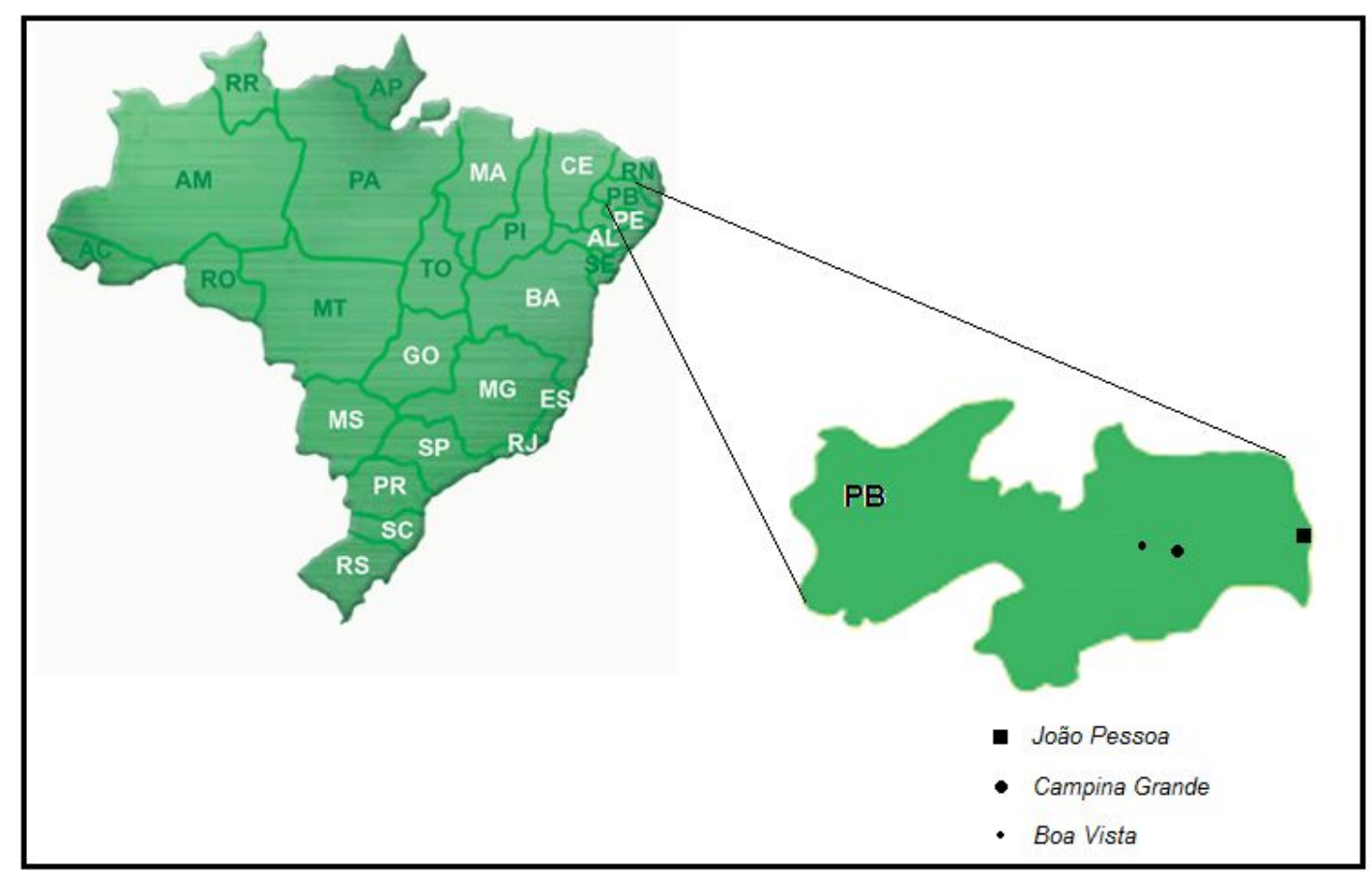

Figura 1.1 - Localização aproximada da cidade de Boa Vista - PB.

Assim a abordagem das argilas do tipo Bofe nesta Tese, mesmo possuindo qualidade inferior a algumas esmectitas habitualmente utilizadas, deve-se ao fato mencionado das argilas esmectíticas de melhor qualidade estarem se exaurindo e as Bofes apresentarem grande abundância.

\section{Objetivo}

Mediante o exposto, esta tese tem como objetivo, avaliar o potencial de uso de argilas do tipo Bofe a partir de 2 tipos de tratamentos: ativação ácida e organofilização.

\section{Objetivos específicos}

1) Caracterizar quatro amostras de argila bentonítica natural proveniente da cidade de Boa Vista - PB do tipo Bofe pelas técnicas de Difração de Raios-X 
(DRX), Espectroscopia na Região do Infravermelho (FTIR), Análise Térmica (TG, DTG e DTA) e Microscopia Eletrônica de Varredura (MEV).

2) Realizar tratamento químico, através da ativação ácida, com ácido clorídrico.

3) Caracterizar as amostras ativadas pelas técnicas de Difração de Raios- $X$ (DRX), Espectroscopia na Região do Infravermelho (FTIR) e Análise Térmica (TG, DTG e DTA).

4) Medir, com as amostras naturais e ativadas o poder descorante em óleo de soja.

5) Obter argilas organofílicas a partir de três sais quaternários de amônio.

6) Caracterizar as amostras organofílicas pelas técnicas de Difração de Raios-X (DRX), Espectroscopia na Região do Infravermelho (FTIR), Análise Térmica (TG, DTG e DTA) e Microscopia Eletrônica de Varredura (MEV).

7) Realizar teste de inchamento de Foster, em diversos solventes orgânicos, com as amostras organofílicas.

8) Testar o uso das argilas organofílicas preparadas como sorvente de hidrocarbonetos: Gasolina, Diesel, Querosene e Tolueno. 
argilasativaçãoquimicaorganofiliza ãoesmectíticasbentonitasestudoáci

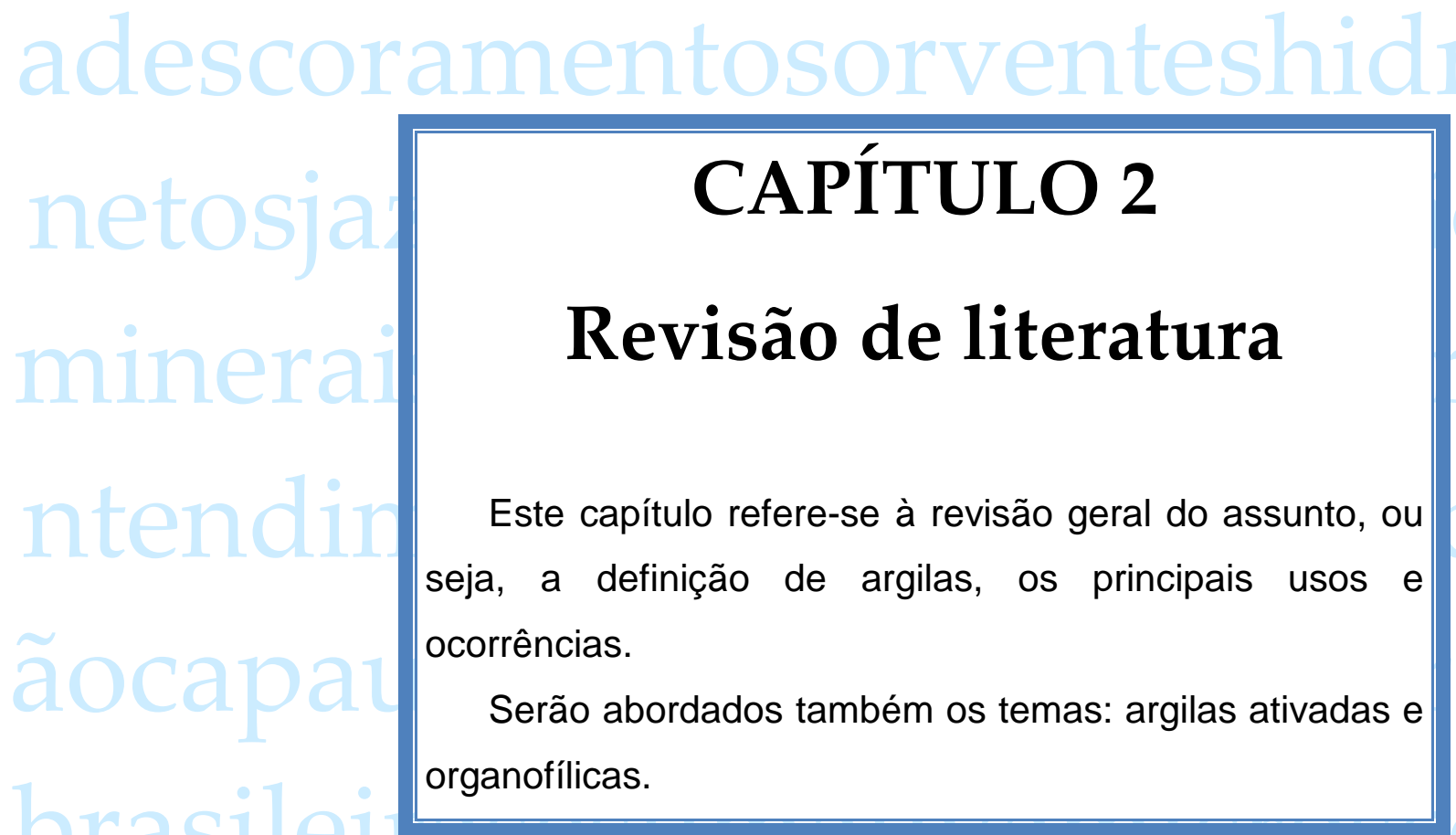

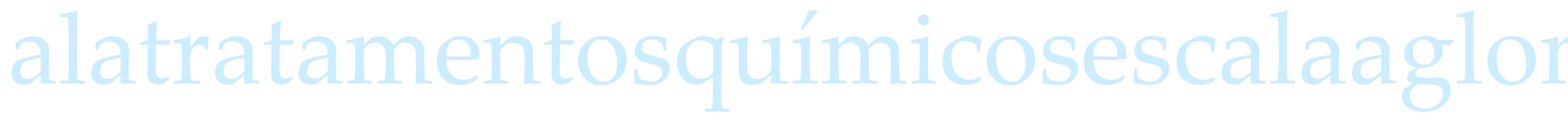

eradoslocalizadasreaçãotempossai
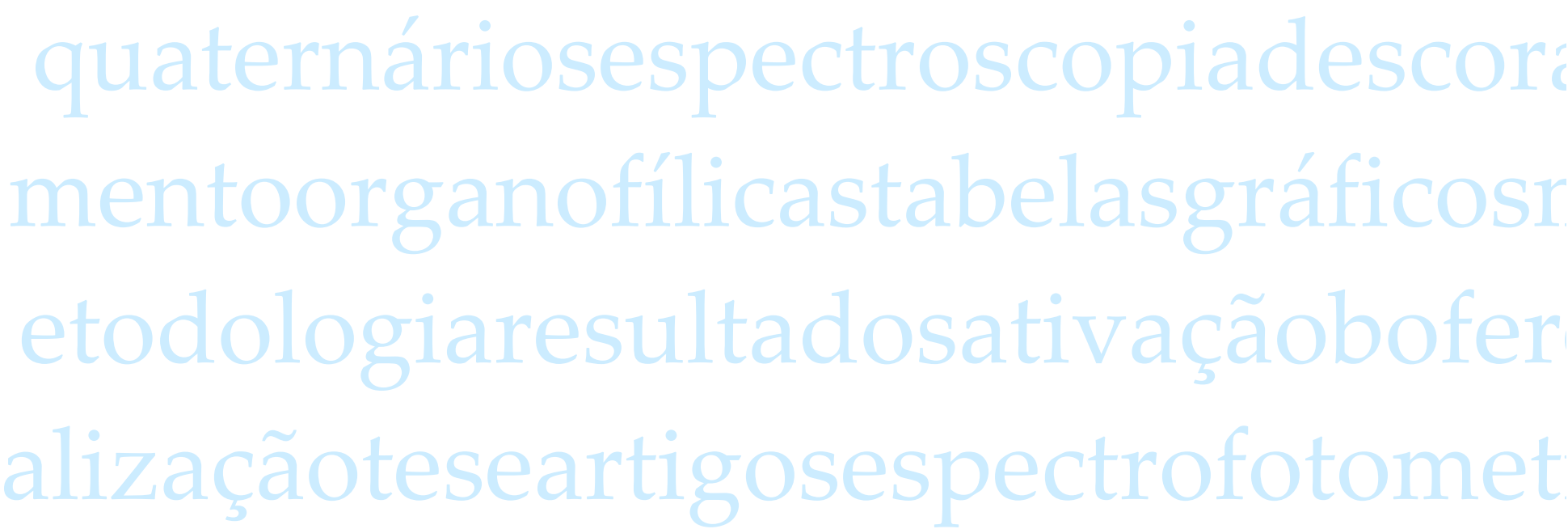


\subsection{Argilas}

As argilas são rochas sedimentares formadas pela alteração dos silicatos de alumínio componentes de rochas, quer de origem magmática, metamórficas ou sedimentares. Os silicatos de alumínio mais abundantes são os feldspatos e as micas. É principalmente da decomposição desses minerais que resultam as grandes massas de argila que cobrem a superfície do solo e enchem as depressões dos terrenos [ABREU, 1973].

Embora não aparente, os minerais específicos das argilas (os argilominerais) são constituídos por minúsculos cristais que, unidos uns aos outros, formam grãos menores que $0,01 \mathrm{~mm}$. Na determinação de sua composição química aparecem como elementos essenciais a sílica $\left(\mathrm{SiO}_{2}\right)$, e a alumina $\left(\mathrm{Al}_{2} \mathrm{O}_{3}\right)$, além de óxidos de ferro $\left(\mathrm{Fe}_{2} \mathrm{O}_{3}\right)$, magnésio $(\mathrm{MgO})$, cálcio $(\mathrm{CaO})$, sódio $\left(\mathrm{Na}_{2} \mathrm{O}\right)$, potássio $\left(\mathrm{K}_{2} \mathrm{O}\right)$ e outros, assim como quantidades variáveis de água de constituição [LIRA FILHO, 1973].

Segundo Gomes [1988] o termo argila é usado atualmente com vários sentidos: para o ceramista, a argila é um material natural que quando misturado com água, em quantidade adequada, se converte numa pasta plástica e que após secagem e queima adquire dureza de aço; para o petrologista, é um agregado de partículas minerais muito finas e não identificáveis ao olho nu; para o mineralogista, a argila designa mineral ou mistura de minerais em que dominam os chamados argilominerais que são silicatos hidratados em que podem participar cátions como $\mathrm{Al}^{3+}, \mathrm{Fe}^{2+}, \mathrm{Mg}^{2+}, \mathrm{K}^{+}$entre outros; apresentam estrutura essencialmente filitosa e granulometria muito fina; para os engenheiros civis são a parte do solo com granulometria inferior a malha ABNT $200(0,075 \mathrm{~mm})$; ou simplesmente para o leigo, que argila ou barro é um material natural, que estando úmido "a bota se enterra e agarra ou onde escorrega".

Segundo Souza Santos [1975] a argila é um material natural (rocha), terroso, de granulometria fina, que geralmente adquire, quando umedecido com água, certa plasticidade, e rigidez depois de submetido a aquecimento adequado.

As argilas são geralmente constituintes de algumas argilas especiais (que recebem nomes específicos como caulim e bentonita), também chamadas "argilas industriais", são matérias-primas para alguns segmentos das Indústrias de Processamento Químico e também são objeto de estudo da Engenharia Química, da 
Química e da Ciência e Tecnologia dos Materiais [VALENZUELA DÍAZ; SOUZA SANTOS; SOUZA SANTOS, 1992].

Souza Santos [1975] caracteriza as argilas por:

> Serem constituídas essencialmente por argilominerais, geralmente cristalinos; podendo conter minerais que não são considerados argilominerais (calcita, dolomita, gibsita, quartzo, aluminita, pirita e outros), matéria orgânica e outras impurezas.

> Possuir elevado teor de partículas de diâmetro equivalente abaixo de $2 \mu \mathrm{m}$;

> Quando pulverizadas e umedecidas, tornam-se plásticas e após secagem são duras e rígidas e após queima (superior a $1000^{\circ} \mathrm{C}$ ) adquirem dureza de aço;

> Possuir capacidade de troca de cátions entre 3 e 150meq $/ 100 \mathrm{~g}$ de argila.

> Ser constituídas por um ou mais argilominerais e de minerais presentes, em maior ou menos proporção, como impurezas.

\subsection{Argilominerais}

Argilominerais são os minerais constituintes das argilas, geralmente cristalinos; quimicamente são silicatos de alumínio hidratados, contendo em certos tipos outros elementos. Após moagem, formam com água uma pasta mais ou menos plástica, que endurece após a secagem ou após a queima [SOUZA SANTOS, 1989].

Num argilomineral, os elementos mais freqüentes: oxigênio, silício, alumínio, ferro, magnésio, potássio e sódio, no estado iônico, assemelham-se a esferas que se arranjam em modelos estruturais tridimensionais. Essas esferas são as unidades construtoras dos minerais argilosos e o seu arranjo pode fazer-se segundo sete modelos diferentes, donde a consideração de sete grupos sistemáticos nos minerais argilosos cristalinos [GOMES, 1988].

A definição mais recente de argilomineral como um filossilicato é a seguinte: argilominerais pertencem à família dos filossilicatos e contêm folhas tetraédricas bidimensionais contínuas de composição $\mathrm{T}_{2} \mathrm{O}_{5}(\mathrm{~T}=\mathrm{Si}, \mathrm{Al}, \mathrm{Be} \ldots)$ com os tetraedros ligados por três vértices comuns e com o quarto vértice apontando para qualquer direção. As folhas tetraédricas estão ligadas, na unidade estrutural, às folhas 
octaédricas ou a grupos de cátions coordenados ou a cátions individuais [VALENZUELA DÍAZ; SOUZA SANTOS, 2001].

Os diferentes minerais constituintes das argilas são caracterizados não só pela composição química, mas também pelas cargas iônicas [ABREU, 1997]. A Tabela 2.2.1 apresenta as composições químicas de minerais argilosos mais representativos.

Tabela 2.2.1 - Análise química de argilas típicas.

\begin{tabular}{lcccccccc}
\hline & $\begin{array}{c}\text { Caolinita } \\
\text { E.U.A }\end{array}$ & $\begin{array}{c}\text { Montmorilo } \\
\text { nita } \\
\text { França }\end{array}$ & $\begin{array}{c}\text { Saponita } \\
\text { E.U.A }\end{array}$ & $\begin{array}{c}\text { Clorita } \\
\text { E.U.A }\end{array}$ & $\begin{array}{c}\text { Vermiculita } \\
\text { Kenia }\end{array}$ & $\begin{array}{c}\text { Sepiolita } \\
\text { E.U.A }\end{array}$ & $\begin{array}{c}\text { Paligorsqui } \\
\text { ta } \\
\text { Rússia }\end{array}$ & $\begin{array}{c}\text { Atalpugita } \\
\text { E.U.A }\end{array}$ \\
\hline $\mathrm{SiO}_{2}$ & 46,90 & 51,14 & 44,00 & 23,68 & 34,04 & 54,83 & 51,17 & 55,03 \\
$\mathrm{Al}_{2} \mathrm{O}_{3}$ & 37,04 & 19,76 & 10,60 & 25,20 & 15,37 & 0,28 & 13,73 & 10,24 \\
$\mathrm{FeO}_{2}$ & 0,65 & 0,83 & tr. & - & 8,01 & 0,45 & 1,55 & 3,53 \\
$\mathrm{FeO}$ & - & - & - & - & - & - & 0,30 & - \\
$\mathrm{MgO}$ & 0,27 & 3,22 & 24,30 & 26,96 & 22,58 & 24,51 & 6,40 & 10,49 \\
$\mathrm{CaO}$ & 0,29 & 1,62 & 2,00 & 0,28 & - & 0,55 & 2,89 & - \\
$\mathrm{K}_{2} \mathrm{O}$ & 0,84 & 0,11 & - & - & - & 0,03 & - & 0,47 \\
$\mathrm{Na}_{2} \mathrm{O}$ & 0,14 & 0,04 & - & - & - & 0,35 & - & - \\
$\mathrm{TiO}_{2}$ & 0,18 & - & - & - & - & - & - & - \\
$\mathrm{H}_{2} \mathrm{O}$ & - & 14,81 & 12,60 & - & & 8,18 & 10,29 & 9,73 \\
$\mathrm{H}_{2} \mathrm{O}+$ & 12,95 & 7,99 & 6,20 & 11,70 & 19,93 & 10,47 & 13,24 & 10,13 \\
$\mathrm{~T}_{+}$ & 99,92 & 99,52 & 99,70 & 99,52 & 99,93 & 99,92 & 99,58 & 99,62 \\
\hline
\end{tabular}

Fonte: Grim [1953].

\subsubsection{Propriedades dos principais argilominerais}

Segundo Abreu [1973], as propriedades dos principais argilominerais são:

Caulinita: mineral branco, de partículas cristalinas em placas hexagonais, corresponde a fórmula química $\mathrm{Al}_{2} \mathrm{O}_{3} \cdot 2 \mathrm{SiO}_{2} \cdot 2 \mathrm{H}_{2} \mathrm{O}$. Estruturalmente é composta de camadas de silicato formada de um folha de tetraedros de silício e oxigênio e outra de octaedros de alumínio e hidroxilas unidos por fracas ligações de hidrogênio.

Montmorilonita: mineral hidratado, de partículas muito finas, de fórmula teórica $4 \mathrm{SiO}_{2} \cdot \mathrm{Al}_{2} \mathrm{O}_{3} \cdot \mathrm{H}_{2} \mathrm{O} \cdot \mathrm{nH}_{2} \mathrm{O}$, entre as várias admitidas, mas apresentando 
composição muito variável pela facilidade de substituição na rede espacial, podendo conter também $\mathrm{FeO}, \mathrm{CaO}, \mathrm{Na}_{2} \mathrm{O}$ e $\mathrm{K}_{2} \mathrm{O}$.

Vermiculita: silicato altamente hidratado de alumínio e de magnésio (podendo conter cálcio e níquel), apresentando-se em placas paralelas hexagonais. A fórmula atribuída à vermiculita é $4 \mathrm{MgO} \cdot \mathrm{Al}_{2} \mathrm{O}_{3} \cdot 4 \mathrm{SiO}_{2} \cdot 6 \quad \frac{1}{12} \mathrm{H}_{2} \mathrm{O}$. Existem na forma microscópica e macroscópica.

Clorita: nome inicialmente usado para indicar um grupo de silicatos hidratados de cor verde. Geralmente não apresentam uso industrial, podendo fazer parte dos argilominerais constituintes das argilas comuns para Cerâmica Vermelha.

Sepiolita: argilomineral magnesiano, é um material terroso ou fibroso, formado de silicato de magnésio hidratado, fórmula química $2 \mathrm{MgO} \cdot 3 \mathrm{SiO}_{2} \cdot 2$ ou $4 \mathrm{H}_{2} \mathrm{O}$.

Paligorsquita: representa uma família de hidrossilicatos de estrutura fibrosa, formando séries isomórficas entre dois membros-limites: um limite aluminoso e outro magnesiano.

\subsubsection{Estrutura dos argilominerais}

As camadas dos argilominerais são constituídas por folhas que estruturalmente são de dois tipos: tetraedros ou octaedros. Na folha de tetraedros, Figura 2.2.2.1b, o cátion dominante é o $\mathrm{Si}^{4+}$, mas $\circ \mathrm{Al}^{3+}$ o substitui freqüentemente $\mathrm{e}$ o $\mathrm{Fe}^{3+}$ ocasionalmente. A folha de octaedros, Figura 2.2.2.1d, pode ser vista como dois planos de oxigênios estreitamente empacotados com cátions ocupando os sítios octaédricos resultantes entre dois planos, esses cátions são usualmente: $\mathrm{Al}^{3+}$, $\mathrm{Mg}^{2+}, \mathrm{Fe}^{2+}$ ou $\mathrm{Fe}^{3+}$ [MOORE; REYNOLDS Jr., 1989]. 


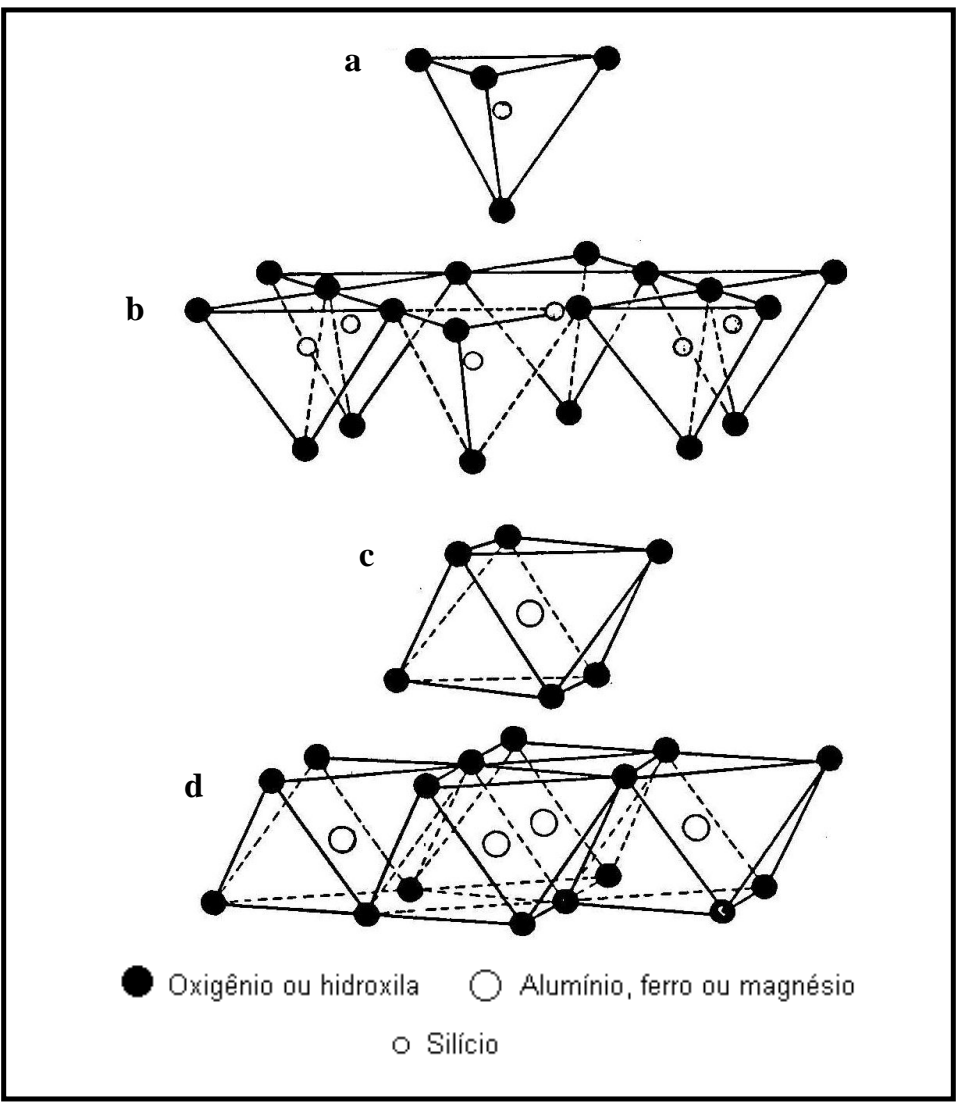

Figura 2.2.2.1 - a. Tetraedro de $\mathrm{SiO}_{4}$; b. folha de tetraedros (os tetraedros de $\mathrm{SiO}_{4}$ associam-se em arranjos hexagonais); c. octaedro em que o átomo coordenado pode ser Al, Fe ou Mg; d. folha de octaedros. Adaptada de Gomes [1988].

O Comitê Internacional para o Estudo de Argilas [MACKENZIE, 1959] recomenda a seguinte subdivisão para os argilominerais cristalinos, em duas classes gerais: a) silicatos cristalinos com estrutura em camadas ou lamelas e b) silicatos cristalinos com estrutura fibrosa. Os silicatos de estrutura lamelar podem ser divididos em dois grupos ou famílias:

a) camadas $1: 1$ ou difórmicos.

b) camadas 2:1 ou trifórmicos.

A nomenclatura 1:1 e 2:1 (Figura 2.2.2.2), se prende ao número de camadas de tetraedros $\mathrm{SiO}_{4}$ e de octaedros de hidróxidos, respectivamente, que entram na constituição da cela unitária da estrutura cristalina do argilomineral [SOUZA SANTOS, 1989]. 
(a)

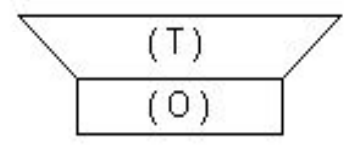

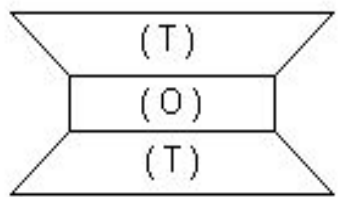

(b)

(a) camada tipo 1:1 - agrupamento de 1 folha de tetraedros (T) e 1 folha de octaedros (O)

(b) camada tipo 2:1 - agrupamento de 2 folhas de tetraedros $(\mathrm{T})$ e 1 folha de octaedros $(\mathrm{O})$

Figura 2.2.2.2 - Representação esquemática do agrupamento das folhas de tetraedros e octaedros. Adaptada de Abreu [1997].

\subsection{Aplicações}

As argilas são substâncias naturais de interesse industrial da maior importância e variados produtos se fazem com elas ou com o auxílio delas [DANA, 1969; TATUM, 1987]. Tem vasto campo de aplicação, desde o barro bruto impuro até as mais finas qualidades fornecidas pelas usinas de beneficiamento com pureza garantida por análises químicas, exames físicos e controles eletrônicos, e/ou com a sua superfície sendo quimicamente modificada, assim, a utilização das argilas na indústria é de grande valor econômico [ABREU, 1973].

O grande número de usos industriais das argilas não é causa e sim a conseqüência de um conjunto de fatores que são específicos para as argilas e que outros minerais não os possuem simultaneamente [SOUZA SANTOS, 1975], esses fatores são:

1. As argilas são constituídas por argilominerais, os quais compreendem vários grupos, que incluem diversas espécies mineralógicas.

2. As diversas espécies mineralógicas apresentam composições químicas diferentes, quer devido às estruturas cristalinas (silicatos de alumínio e/ou magnésio hidratados), quer devido às substituições isomórficas $(A)^{3+}$ substituindo $\mathrm{Si}^{4+}$ e $\mathrm{Fe}^{2+}$ substituindo $\mathrm{Mg}^{2+}$ ), quer devido aos cátions trocáveis $\left(\mathrm{Na}^{+}, \mathrm{K}^{+}, \mathrm{Mg}^{2+}, \mathrm{Ca}^{2+}, \mathrm{H}_{3} \mathrm{O}^{+}, \mathrm{Fe}^{3+}, \mathrm{Al}^{3+}\right)$.

3. As diversas espécies mineralógicas apresentam propriedades físicoquímicas variando numa faixa ampla de valores (capacidade de troca de cátions entre $3 \mathrm{meq} / 100 \mathrm{~g} \mathrm{e} 150 \mathrm{meq} / 100 \mathrm{~g}$ ), baixa granulometria (peneira ABNT 
no 325), de forma anisométrica das partículas (lamelar ou tubular-fibrilar) com a relação diâmetro/espessura ou comprimento/diâmetro variando numa faixa ampla de valores.

4. As argilas são rochas naturalmente divididas, sendo necessário para se obter a individualização das partículas apenas uma desagregação que é muito mais barata que a moagem.

5. São constituintes de sedimentos flúvio-lacustres, por isso estão freqüentemente próximas às comunidades humanas.

6. São facilmente dispersáveis em água (e em outros solventes) podendo dar suspensões instáveis ou estáveis, com uma faixa ampla de propriedades reológicas.

Nenhum material extraído da terra tem tantas e tão variadas aplicações como as argilas. Na verdade, podem considerar-se como um dos minérios principais. Desde há mais de 10.000 anos o homem vem usando as argilas e para ela vai encontrando novas aplicações [GOMES, 1988].

Grim [1953], citado por Valenzuela Díaz; Souza Santos; Souza Santos [1992.a], baseado na definição de que argila é uma rocha constituída essencialmente por argilominerais, estabeleceu o seguinte princípio: "o uso industrial de uma argila, em uma Indústria de Processamento Químico, é conseqüência da natureza e das propriedades do argilomineral que é componente essencial dessa argila, bem como dos cátions trocáveis da mesma".

Segundo Souza Santos [1975] e Gomes [1988], o Brasil possui atualmente indústrias que utilizam argilas de diversos tipos, suas grandes aplicações industriais são mencionadas a seguir:

- Cerâmica: na fabricação de cerâmica vermelha, branca e material refratário. A argila pode ser trabalhada facilmente e, após queima, a forma escolhida permanece e o objeto torna-se resistente, térmica e mecanicamente.

Borracha e plástico: utilizam as argilas como cargas e inertes. Quando incorporadas a borracha conferem propriedades mecânicas superiores às da borracha vulcanizada sem carga.

> Papel: utilizam as argilas como carga e cobertura. Se na composição do papel entrasse só celulose, ele não permitiria boa impressão e reprodução devido à transparência e irregularidade da superfície e, estas deficiências são 
corrigidas pela incorporação de cargas ou enchimentos minerais e a adição de agentes ligantes. Num quilo de papel de revista entram cerca de $200 \mathrm{~g}$ de caulim.

Metalúrgica: aglomerante de areias de moldagem. Para a fundição de metais e para pelotização de minérios de ferro. A função do aglomerante é proporcionar ao molde resistência mecânica.

> Inseticidas: diluente primário e secundário.

Óleos e derivados do petróleo: agente descorante de óleos. Argilas especiais são usadas como componentes de catalisadores para craqueamento de petróleo para produção de gasolina e seu alto poder adsorvente é usado na clarificação de óleos minerais, vegetais e animais.

Sondagem de petróleo: agentes tixotrópicos. Em fluidos para a perfuração de poços.

Agricultura: adsorvente. Os minerais argilosos do solo adsorvem fácil e rapidamente minerais livres que estando debilmente fixados, podem ser facilmente trocados por outros com maior valor para as plantas.

Outros usos: tem ainda largo emprego na fabricação de pigmento e de sulfato de alumínio; como cargas em tintas e diversos produtos calcinados; em fundição; na arte.

Desde os tempos mais antigos, a argila é um dos materiais mais utilizados pelo homem [SILVA SANTOS, et al., 2001]. Atualmente, várias áreas da Ciência têm as argilas como um dos seus objetivos de estudos [VALENZUELA DÍAZ; SOUZA SANTOS; SOUZA SANTOS, 1992.b].

\subsection{Grupos de argilominerais}

Os argilominerais são classificados em grupos [SOUZA SANTOS, 1989], em função quer da composição química, quer das características da estrutura cristalina, isto é, como se organizam as diferentes celas unitárias. Assim, têm-se os seguintes grupos, com alguns exemplos de argilominerais pertencentes aos mesmos:

a) Grupo da caulinita: caulinita e haloisita;

b) Grupo das serpentinas: amianto crisotila, antigorita; 
c) Grupo do talco-pirofilita: talco e pirofilita;

d) Grupo das micas: mica moscovita; sericita e ilita; biotita; lepidolita;

e) Grupo das esmectitas: montmorilonita propriamente dita; saponita; nontronita; hectorita; sauconita; beidelita e volconscoíta

f) Grupo das vermiculitas: macro-vermiculitas;

g) Grupo das cloritas: não tem uso industrial;

h) Grupo da paligorsquita (ex-atapulgita)/sepiolita: ambos argilomineraispaligorsquita e sepiolita;

i) Camadas mistas: ilita-montmorilonita e montmorilonita-vermiculita.

j) Mineralóides: não tem uso industrial.

\subsubsection{Esmectitas}

Esmectita é o nome de um grupo de alumino-silicatos de sódio, cálcio, magnésio, ferro, potássio e lítio, que inclui os argilominerais: montmorilonita, nontronita, saponita, hectorita, sauconita, beidelita e volconscoíta. A rocha na qual esses argilominerais são dominantes é chamada de bentonita [ULLMANN'S, 1986]. É comum encontrar-se esmectitas em mistura com outros argilominerais (ilita, microvermiculita) ou em argilominerais interestratificados como ilita/montmorilonita [SOUZA SANTOS, 1992].

São minerais hidratados, de partículas muito finas, de fórmula teórica para a meia cela unitária $\mathrm{M}_{\mathrm{x}+\mathrm{y}}^{+}\left(\mathrm{Al}_{2-\mathrm{y}} \mathrm{Mg}_{\mathrm{y}}\right)\left(\mathrm{Si}_{4-\mathrm{x}} \mathrm{Al} \mathrm{I}_{\mathrm{x}}\right) \mathrm{O}_{10} \cdot(\mathrm{OH})_{2}$, onde $\mathrm{M}^{+}$é cátion monovalente e $(x-y)$ e $(x+y)$ variam entre 0,3 e 0,5. Apresentam composição muito variável pela facilidade de substituição na rede espacial, tendo-se substituições isomórficas tetraédricas, por exemplo: os $\mathrm{Si}^{4+}$ sendo substituídos por $\mathrm{Al}^{3+}$ ou substituições octaédricas, como por exemplo: $\mathrm{Al}^{3+}$ sendo substituído por $\mathrm{Mg}^{2+}$ [SOUZA SANTOS, 1989].

Essas substituições isomórficas provocam uma densidade de carga negativa na superfície dos argilominerais esmectíticos, a qual é compensada pelos cátions interlamelares, situados entre os cristais (camadas) dos argilominerais esmectíticos (ver Figuras 2.4.1.1, 2.4.1.2, 2.5.1). Os tipos e porcentagens de cada um desses 
cátions que constituem a população catiônica interlamelar ditam, geralmente, as propriedades físico-químicas e tecnológicas das argilas esmectíticas.

Os argilominerais deste grupo são constituídos por duas folhas de tetraedros, com uma folha central de octaedros, unidas entre si por oxigênios comuns às folhas [SOUZA SANTOS, 1975]. A Figura 2.4.1.1 mostra o diagrama esquemático da estrutura cristalina das esmectitas.

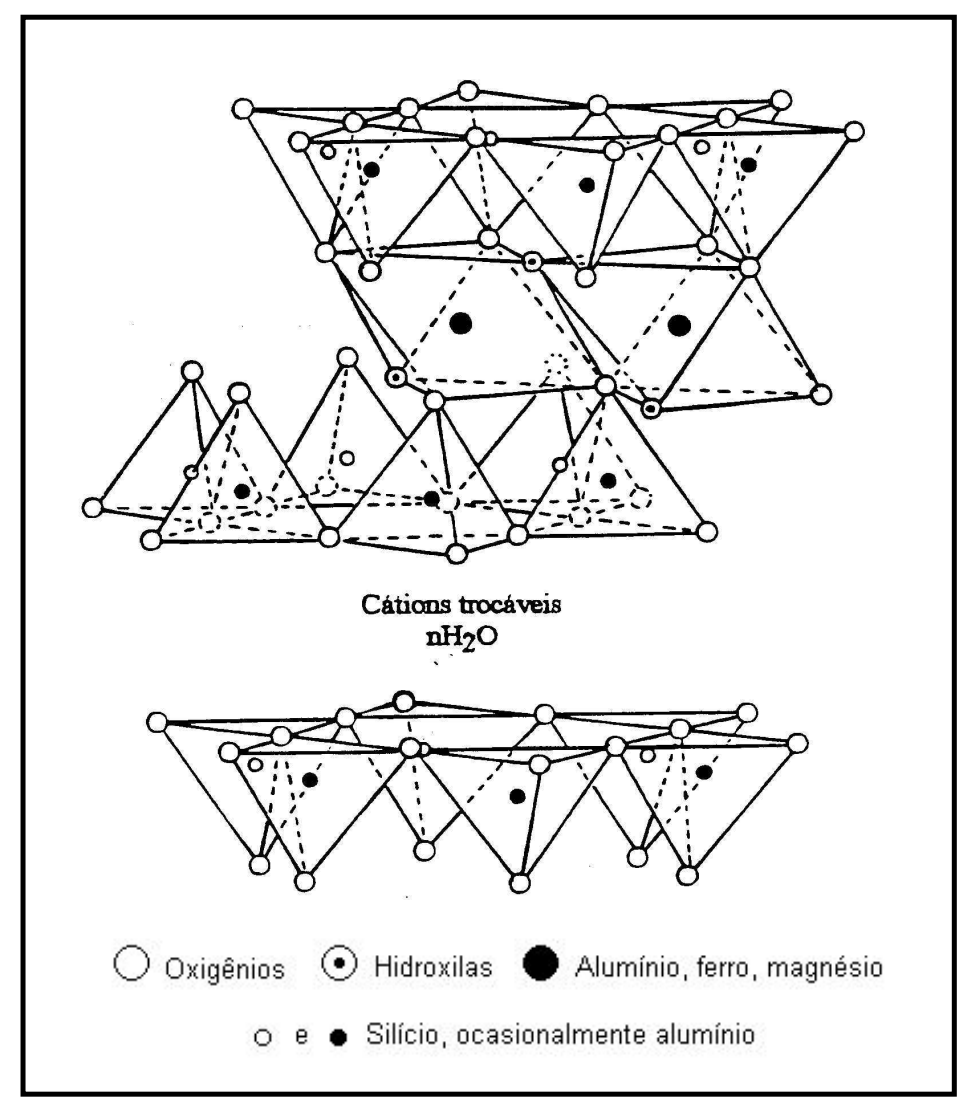

Figura 2.4.1.1 - Diagrama esquemático da estrutura cristalina das esmectitas. Adaptada de Grim [1962].

As esmectitas sódicas e com alto inchamento em água, isto é, contendo o sódio como cátion interlamelar preponderante e aumentando macroscopicamente de volume quando em contato com água, são as de maior utilização industrial. Os usos industriais das argilas dependem dos cátions trocáveis existentes. Por exemplo, para utilização como componentes de fluidos de perfuração em poços de petróleo à base de água, a presença do sódio como cátion predominante é necessária. Quando a argila não é, na sua forma natural, predominantemente sódica (como as bentonitas norte-americanas de Wyoming que são naturalmente sódicas) isso pode ser 
conseguido por meio de reação química de dupla troca, reversível, usando-se o carbonato de sódio [RAMOS, 1985].

Quando estes argilominerais são colocados em água ou em ambientes úmidos, os cátions trocáveis se hidratam, entra água e o espaçamento basal aumenta: nessas condições, os cátions interlamelares são suscetíveis de serem trocados por outros cátions por uma reação química de dupla troca [SOUZA SANTOS, 1975].

O grupo das esmectitas é considerado o mais interessante dos argilominerais. É um grupo de minerais dioctaédricos ou trioctaédricos (por cela unitária existem 6 posições octaédricas passíveis de serem ocupadas, quando todas são ocupadas temos os argilominerais octaédricos, quando 2/3 das posições são ocupadas os dioctaédricos), todos possuindo a capacidade de expandir a sua estrutura (camadas tipo 2:1), aumentando o espaço interlamelar e conseqüentemente a distância basal $\left(\mathrm{d}_{001}\right)$ (Figura 2.4.1.2). A expansão (ou inchamento) ocorre quando a água ou algum composto orgânico como etilenoglicol, penetram no espaço interlamelar [ABREU, 1997].

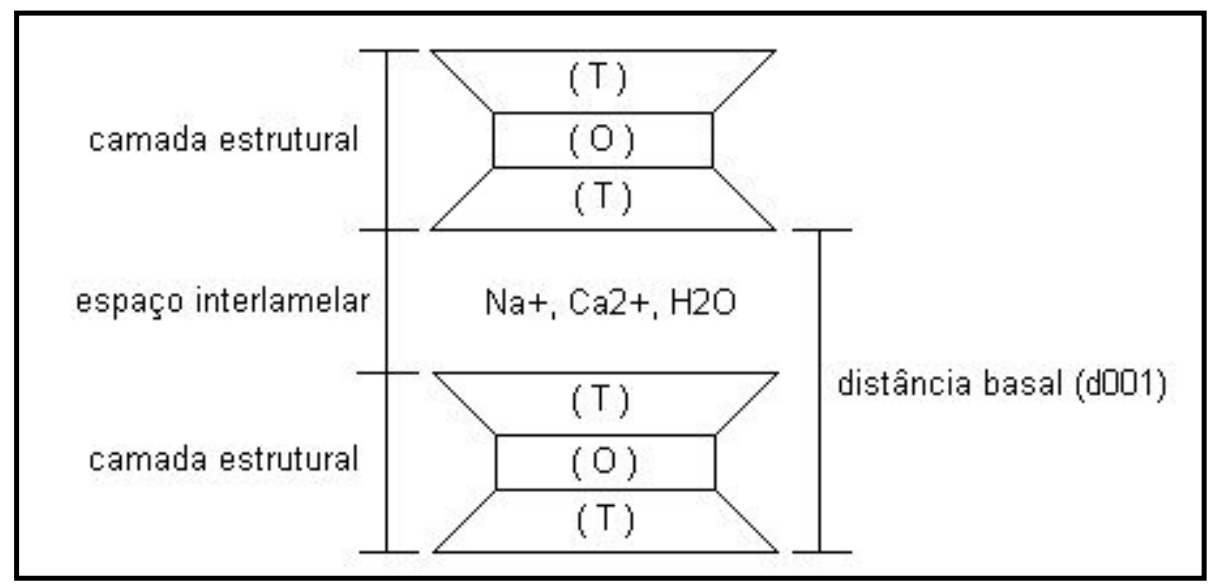

Figura 2.4.1.2 - Representação do espaço interlamelar e da distância basal das argilas esmectíticas. Adaptada de Abreu [1997].

O inchamento ou expansão das esmectitas em contato com água é quase que certo, devido à sua carga da camada relativamente baixa. Talvez a causa principal seja que não exista uma atração grande o suficiente dos cátions interlamelares para manter as camadas juntas. $\mathrm{Na}$ presença de água, o 
comportamento de inchamento é uma função tanto do tamanho quanto da carga dos cátions interlamelares presentes [MOORE; REYNOLDS Jr., 1989].

\subsection{Bentonita}

Os povos antigos aprenderam muito cedo que materiais argilosos não só serviam para fins cerâmicos. Argilas do tipo montmorilonítico foram bastante usadas para confecção de tintas, cosméticos e desengordurantes de utensílios domésticos. Existem referências de vários povos, principalmente egípcios, gregos e romanos que já mineravam argilas para atender a estas finalidades [LIRA FILHO, 1973].

Atualmente, defini-se bentonita como sendo uma argila constituída essencialmente por um ou mais argilominerais do grupo das esmectitas (montmorilonita propriamente dita; beidelita; nontronita; saponita; sauconita; volconscoita; hectorita), não importando qual seja a origem geológica; essa definição substitui a antiga que vinculava à alteração de cinzas vulcânicas ácidas [VALENZUELA DÍAZ; SOUZA SANTOS; SOUZA SANTOS, 1992].

Uma definição mais restrita é fornecida por Souza Santos [1992]: uma argila esmectítica que tenha, ou que nela possa ser desenvolvida propriedades, que a permita ter usos tecnológicos análogos as bentonitas tradicionais estrangeiras (caso da bentonita de Wyoming, EUA) ou, mais precisamente, que já sejam utilizadas comercialmente para essa finalidade, pode ser chamada de bentonita, não importando se é ou não originária de cinzas vulcânicas ácidas.

São argilas de granulação muito fina, compostas por minerais do grupo das esmectitas [SOUZA SANTOS, 1989], dotadas de alto teor de matéria coloidal. O nome abrange um grupo de argilas de propriedades semelhantes, de grande capacidade de adsorção, mas não uma espécie definida [ABREU, 1973]. A Figura 2.5.1 mostra, assim como a Figura 2.4.1.1, a estrutura cristalina dos argilominerais esmectíticos, constituintes essenciais das bentonitas. 


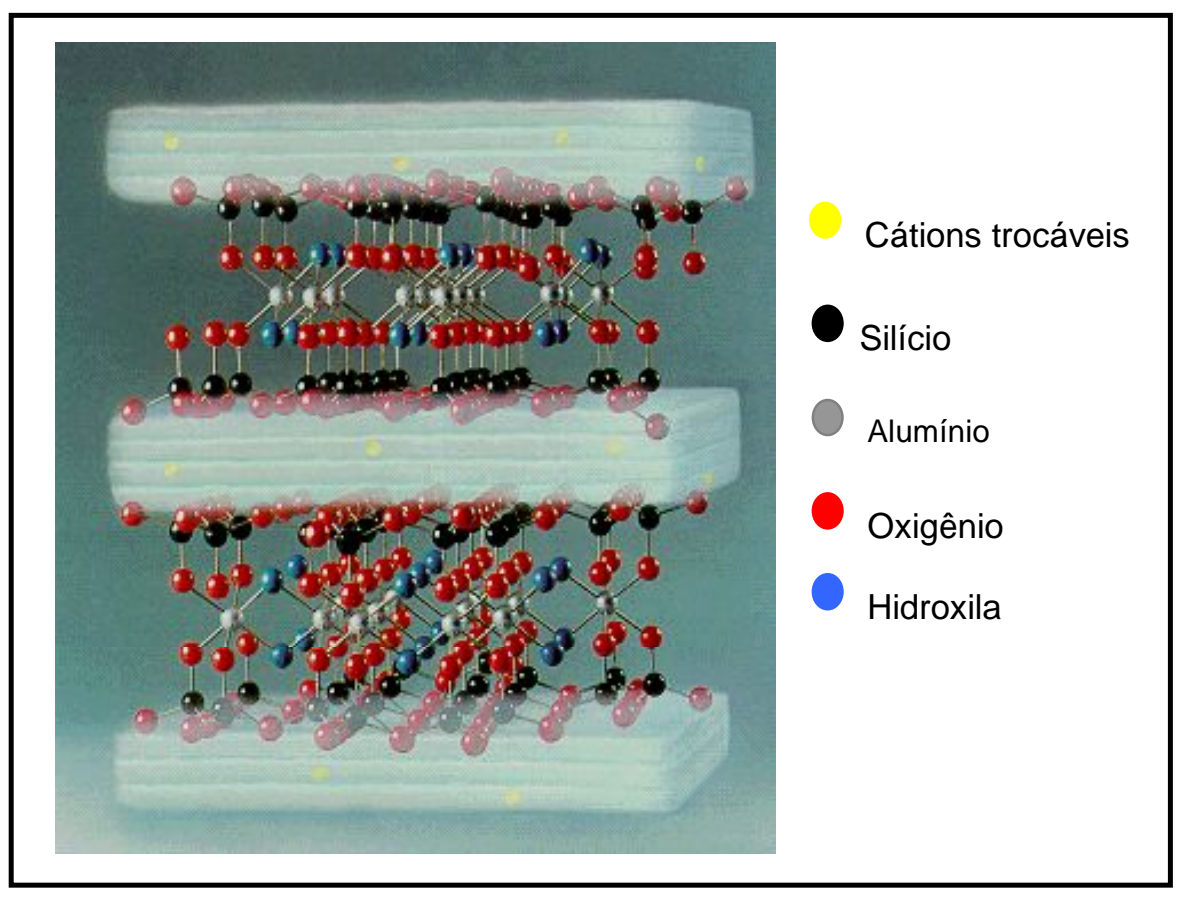

Figura 2.5.1 - Estrutura cristalina da bentonita. Fonte: Catálogo Süd-Chemie.

Seu nome foi dado em função do depósito descoberto em folhelhos argilosos do Fort Benton, Wyoming (EUA), onde essa argila foi pela primeira vez caracterizada como um tipo especial [SOUZA SANTOS, 1975]. Apresentam aspecto de cera, podem ser cortadas em finas fatias; molhadas adquirem características semelhante à do sabão molhado [ABREU, 1973].

Segundo Abreu [1973], as argilas bentoníticas possuem alta capacidade de adsorção e alto teor de matéria coloidal ou, ainda, grande possibilidade de ativação. Tem composição química muito variável e suas aplicações são numerosas. Todos os tipos de bentonita têm alguns ou vários argilominerais do grupo da esmectita, com, geralmente, montmorilonita como argilomineral predominante [SOUZA SANTOS, 1989].

Os minerais do grupo das esmectitas são os componentes principais das chamadas bentonitas e as argilas que os contém são comumente designadas por argilas esmectíticas ou bentoníticas [LIRA FILHO, 1973].

Os tipos de bentonitas mais freqüentes, segundo Valenzuela Díaz; Souza Santos; Souza Santos [1992.a] são:

a) Homocatiônica em sódio (Wyoming, USA)

b) Homocatiônica em cálcio (Mississipi, USA) 
c) Policatiônicas (a maioria das ocorrências, como é o caso Boa Vista/PB).

Essas argilas têm amplo uso industrial na preparação de fluidos de perfuração, como ligante de areias de fundição, na preparação de argilas descorantes de óleos, na manufatura de catalisadores, na indústria de petróleo, na aglomeração de minérios de ferro e manganês, e outros produtos e em outros usos [SOUZA SANTOS, 1975].

Felizmente em relação à mineração e beneficiamento a possibilidade de poluição é praticamente nula, pois, a quase totalidade do material extraído e beneficiado é realmente aproveitada. O material moído, cujos finos poderiam contaminar a atmosfera, é movimentado em tubos fechados, saindo dos silos para os sacos. As suspensões de bentonita sódica, que poderiam contaminar as águas paradas quando do seu uso, floculam e se depositam quando em pequenas quantidades, de forma que grandes concentrações deste tipo de bentonita provavelmente nunca venham a ocorrer em níveis perigosos [LIRA FILHO, 1973].

\subsubsection{Bentonitas que incham e que não incham em água}

Segundo Valenzuela Díaz [1999] e Souza Santos [1975], para uso industrial há dois tipos de argilas esmectíticas: um tipo são as argilas esmectíticas que tem sódio como cátion interlamelar preponderante e a propriedade de inchar em água, apresentando géis tixotrópicos em dispersões aquosas a baixas concentrações de argila; o outro tipo são as argilas esmectíticas que não incham em água, estas são geralmente policatiônicas ou preponderantemente cálcicas, isto é, não contém nenhum cátion interlamelar ou contém cálcio como cátion interlamelar preponderante.

\subsubsection{Bentonitas que incham}

Essas argilas são caracterizadas por sua propriedade específica de inchar até vinte vezes o volume da argila seca, quando imersas em água [SOUZA SANTOS, 
1989]. A bentonita que incha apresenta como cátion de troca o sódio e revela grande tixotropia quando em dispersões aquosas a baixas concentrações de argila (tixotropia entendida aqui como transformação reversível e isotérmica de gel para sol por meio de agitação mecânica), tendo amplo uso industrial [GOMES, 1988].

As argilas esmectíticas que incham em água, quando expostas à umidade atmosférica adsorvem água, apenas até a quantidade correspondente a uma camada monomolecular de água em torno de cada partícula. Em meio aquoso, a argila adsorve continuamente várias camadas de moléculas de água, inchando e aumentando de volume, essa adsorção contínua promove o desfolhamento das partículas proporcionando às argilas esmectíticas, que incham em água, os seus usos tecnológicos exclusivos típicos [VALENZUELA DÍAZ, 1999].

\subsubsection{Bentonitas que não incham}

Podem ter a composição mineralógica das bentonitas que incham, diferindo nos cátions trocáveis [SOUZA SANTOS, 1989], predominantemente $\mathrm{Ca}^{2+}$ e $\mathrm{Mg}^{2+}$, e ainda por não evidenciar tixotropia. Embora haja usos que são comuns a ambos os tipos de bentonita, existe um uso que é específico do tipo que não incha e que parece ser conseqüência do cálcio ou magnésio serem os cátions trocáveis [GOMES, 1988]. Por tratamento com ácidos inorgânicos concentrados, estas bentonitas produzem argilas ativadas, que são utilizadas no descoramento ou branqueamento de óleos e gorduras minerais, vegetais e animais [SOUZA SANTOS, 1989].

A troca do sódio por cálcio ou magnésio em uma bentonita sódica destrói a propriedade de inchar e dispersar espontaneamente em água, além da tixotropia. A argila, em dispersão aquosa, sedimenta e permanece precipitada ou floculada, não formando géis tixotrópicos (isto é, não mais defloculam espontaneamente em água).

As argilas esmectíticas que não incham em água não têm sódio como cátion interlamelar preponderante. As argilas esmectíticas preponderantemente cálcicas (por exemplo), quando expostas à umidade atmosférica adsorvem água até uma quantidade correspondente a três camadas moleculares; em meio aquoso, a adsorção de mais camadas de moléculas de água não ocorre; não se dá o 
desfolhamento acentuado das partículas e estas precipitam rapidamente em dispersões aquosas [VALENZUELA DÍAZ, 1999].

\subsubsection{Usos industriais das bentonitas}

Os principais segmentos consumidores de argila bentonítica, segundo dados do DNPM [2001], no mercado nacional são:

$>$ Indústria petrolífera (agente tixotrópico nas perfurações dos poços de petróleo).

> Indústria siderúrgica (pelotização de minério de ferro).

> Indústria de fundição (aglomerante em sistemas de areia verde demonstrando-se o melhor aglomerante utilizado pelas indústrias de fundição em seus processos de moldagens de peças críticas de ferro fundido, aço e ligas não-ferrosas).

Indústria de tintas e vernizes (espessante).

Indústria vinícola (elemento filtrante e clarificante de vinhos e sucos).

Indústria da construção civil (impermeabilizante de barragens, metrôs, aterros sanitários).

> Perfuração de poços artesianos (estabilizador de solos).

> Indústria alimentícia animal (componente inerte - veículo - para rações).

Indústria farmacêutica e de cosméticos.

\subsubsection{Ocorrências de bentonitas}

A expressiva abundância das reservas mundiais de bentonita dificulta a efetivação da estimativa desses recursos em um contexto global. No Brasil, as reservas (medida + indicada) de bentonita totalizaram aproximadamente 83 milhões de toneladas, das quais $51,4 \%$ são relativas às reservas medidas, distribuídas no Estado do Paraná, Município de Quatro Barras, representando 39,0\% das reservas lavráveis nacionais; no Estado de São Paulo, nos municípios de Pindamonhangaba, 
Taubaté e Tremembé, com 23,4\%; no Estado da Paraíba, no município de Boa Vista com 22,0\% e, no Estado do Piauí, no município Guadalupe com 15,6\% [OLIVEIRA, 2004].

A produção mundial preliminar de bentonita no exercício de 2003 foi de aproximadamente 10,1 milhões de toneladas, destacando-se as produções dos Estados Unidos (3,97 milhões de toneladas/ano); Grécia (1,2 milhões de toneladas/ano); Comunidade dos Estados Independentes - CEl (750 mil toneladas/ano) e Turquia (600 mil toneladas/ano). Não obstante o Brasil figurar entre os dez principais produtores, a produção nacional, nesse contexto, é bastante discreta (199 mil toneladas/ano, representando cerca de $2,0 \%$ da produção mundial) [OLIVEIRA, 2004].

Tabela 2.5.3.1 - Reserva e produção mundial.

\begin{tabular}{l|c|r|r|r|r}
\hline Discriminação & Reservas $(t)$ & \multicolumn{4}{|c}{ Produção $(t)$} \\
\hline Países & $2003^{(p)}$ & $2002^{(r)}$ & $(\%)$ & $2003^{(p)}$ & $(\%)$ \\
\hline Brasil & $82.642 .000^{(1)}$ & 184.909 & 1,8 & 199.212 & 2,0 \\
\hline Estados Unidos & $\ldots$ & 3.970 .000 & 39,7 & 3.970 .000 & 39,3 \\
\hline Grécia & $\ldots$ & 1.150 .000 & 11,5 & 1.200 .00 & 11,9 \\
\hline Alemanha & $\ldots$ & 500.00 & 5,0 & 500.000 & 5,0 \\
\hline República & $\ldots$ & 174.000 & 1,7 & 200.000 & 2,0 \\
Tcheca & $\ldots$ & & & & \\
\hline Turquia & $\ldots$ & 559.000 & 5,6 & 600.000 & 5,9 \\
\hline Outros & $\ldots$ & 2.312 .091 & 23,1 & 2.280 .788 & 22,6 \\
\hline
\end{tabular}

Notas: (1) inclui reservas medidas e indicadas (p) preliminar; $(r)$ revisado; (...) não disponível.

Fonte: OLIVEIRA, 2004.

Dados do DNPM mostram que em 2003, a produção brasileira de bentonita bruta registrou expressivo acréscimo de 38,1\% (319.302t em 2002 para 420.995t em 2003). Em contrapartida, a produção de bentonita beneficiada apresentou um crescimento mais discreto, de 7,7\% em relação ao ano de 2002 (184.909t em 2002 para 199.212t em 2003).

A Paraíba apresenta-se como o principal Estado produtor dessa substância e, atualmente, nove empresas de mineração atuam no estado, concentradas no município de Boa Vista, dentre elas, a principal empresa produtora de bentonita no país, a Bentonit União Nordeste S.A., tendo produzido cerca de 178.200 toneladas de bentonita ativada no ano de 2003. O Estado de São Paulo, segundo maior produtor nacional, possui três empresas em atividade. As empresas Aligra Indústria 
e Comércio de Argila Ltda. e Argos Extração e Beneficiamento de Minerais Ltda. localizam-se no município de Taubaté e, no município de Tremembé, a empresa Sociedade Extrativa Santa Fé Ltda., perfazendo um total de 20.774 toneladas de argila moída seca produzidas no estado de São Paulo durante o exercício de 2003.

\subsection{Ativação ácida}

O processo de ativação é o tratamento químico aplicado a certos tipos de argilas para desenvolver a capacidade para adsorver impurezas em óleos e gorduras vegetais, animais e minerais [BARAÚNA, 1993]. As argilas utilizadas como matéria-prima para a obtenção de argilas ativadas por ácidos são argilas que, no estado natural, têm, geralmente, um poder descorante muito baixo, mas que desenvolvem um elevado poder descorante pelo tratamento com ácido [SOUZA SANTOS, 1992].

Algumas argilas após serem ativadas quimicamente com ácidos, adquirem propriedades catalíticas e adsortivas, e são empregadas industrialmente como catalisadores, suportes catalíticos e adsorventes [PRAKASH; JASRA; BHAT, 1995].

A ativação ácida serve para transformar a montmorilonita em montmorilonita ácida pela substituição do sódio, potássio, cálcio (e talvez magnésio) pelo cátionhidrogênio ou hidroxônio e para reduzir o teor de magnésio, ferro e alumínio. Nessa ativação, parte do hidroxônio é substituído por $\mathrm{Al}^{3+}$ estrutural, com destruição parcial do argilomineral; a ativação ácida serve também para aumentar a área específica, isto é, a área externa total das partículas de argila por unidade de massa e, também, a porosidade aparente das argilas [GRIM, 1962].

A ativação ácida altera a estrutura cristalina, a composição química e as propriedades físicas das argilas, promove uma dissolução parcial dos componentes da esmectita e é caracterizada por uma substituição inicial de cátions interlamelares por $\mathrm{H}^{+}$, seguido pela dissolução das folhas octaédricas e tetraédricas e subseqüente eliminação de cátions estruturais [VALENZUELA DÍAZ; SOUZA SANTOS, 2001, TKAC; KOMADEL, 1994, VALENZUELA DÍAZ; SOUZA SANTOS, 1991].

Ativação das argilas esmectíticas pela ação de ácido é uma técnica muito utilizada na indústria para aumentar tanto a sua capacidade catalítica como 
adsorvente e descorante. Tendo sido observado, que a atividade catalítica dos produtos resultantes eleva-se ao aumentar-se a intensidade do tratamento até um certo limite, o que indica que estes materiais atingem uma transformação ótima em sua composição química e características estruturais, que the conferem a atividade máxima. Este estado ótimo depende de certas variáveis como, natureza e concentração do ácido, tempo de reação, temperatura de processo, relação argila/volume de líquido e tamanho de partícula. Sendo os ácidos sulfúrico e o clorídrico os mais empregados na ativação das esmectitas [SILVA, et al., 2002].

As argilas ativadas com ácidos fortes são largamente usadas em indústrias de papel, óleo mineral, na produção de ácido sulfúrico, indústria de alimentos, na purificação de produtos petroquímicos e também na área de materiais de limpeza [CLARKE, 1985]. Em termos de consumo, o uso mais importante de argilas ativadas é na purificação, branqueamento e estabilização de óleos vegetais [CHRISTIDIS; SCOTT; DUNHAM, 1997].

Dombrowsky e Henderson [1997] mostraram a seguinte lista das mudanças que os cristais das argilas esmectíticas sofrem na ativação com ácidos fortes:

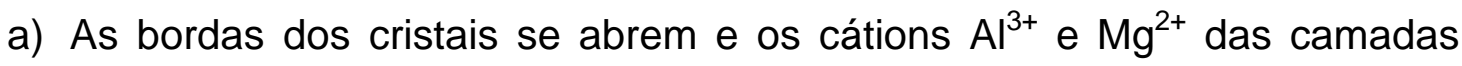
octaédricas ficam expostos ao ácido e se tornam solúveis.

b) A área de superfície, dos poros, aumenta.

c) O grau de cristalinidade do argilomineral, tentativamente avaliado pela intensidade do pico $\left(\mathrm{d}_{001}\right)$, na análise por difração de raios- $\mathrm{X}$, se reduz.

d) A área específica da esmectítica aumenta até um máximo e depois diminui com a continuação do tratamento.

Os seguintes fatos estão experimentalmente bem definidos [DOMBROWSKY; HENDERSON, 1997, GRIM, 1968] para os produtos de esmectitas $\mathrm{Ca} / \mathrm{Mg}$ atacadas com $\mathrm{HCl}$ ou $\mathrm{H}_{2} \mathrm{SO}_{4}$ :

a) Ao aumentar a intensidade do ataque (isto é, aumentando-se a temperatura de reação e/ou o tempo de reação e/ou a relação ácido/argila), a habilidade de descorar um dado óleo ou uma dada gordura, aumenta até obter-se um valor ótimo; após atingir esse máximo, observa-se uma diminuição nessa habilidade. 
b) Aumentando-se a intensidade do tratamento, a área específica, medida por adsorção de $\mathrm{N}_{2}$ (método de BET) aumenta até um máximo; após terse atingido esse máximo, a área específica tende a diminuir de valor.

c) Com o aumento da intensidade do ataque, a intensidade do pico $\left(\mathrm{d}_{001}\right)$ diminui.

d) A diminuição na área específica, após ter-se obtido o máximo pode vir acompanhada pelo aumento da intensidade do pico ( $\left.\mathrm{d}_{001}\right)$, indicando um possível rearranjo das camadas do argilomineral após a produção (e possível precipitação nas plaquetas) de sílica amorfa.

Vários autores têm estudado as mudanças físico-químicas que as argilas sofrem após serem submetidas a tratamentos com ácidos, Valenzuela Díaz e Souza Santos [2001] publicaram uma revisão sobre estudos de ataque ácido em bentonitas brasileiras.

\subsection{Argilas organofílicas}

A quase totalidade dos compostos argilas + substâncias orgânicas foi sintetizada com bentonitas. Dessas argilas, as que continham montmorilonita propriamente foram as mais usadas, estando em primeiro lugar a bentonita de Wyoming [SOUZA SANTOS, 1992].

Souza Santos [1992] afirma que a preferência quanto ao uso de esmectitas nessas sínteses deve-se às pequenas dimensões dos cristais e à elevada capacidade de troca de cátions (CTC) desses argilominerais: isso faz com que as reações de intercalação sejam muito rápidas e que as trocas sejam 100\% completas. Por outro lado, a expansão que ocorre na distância interplanar basal permite seu estudo preciso por difração de raios- $X$ e por espectroscopia no infravermelho. A Figura 2.7.1 apresenta um diagrama esquemático de uma argila organofílica, onde uma molécula de sal quaternário foi introduzida nas camadas interlamelares de uma argila bentonítica. 


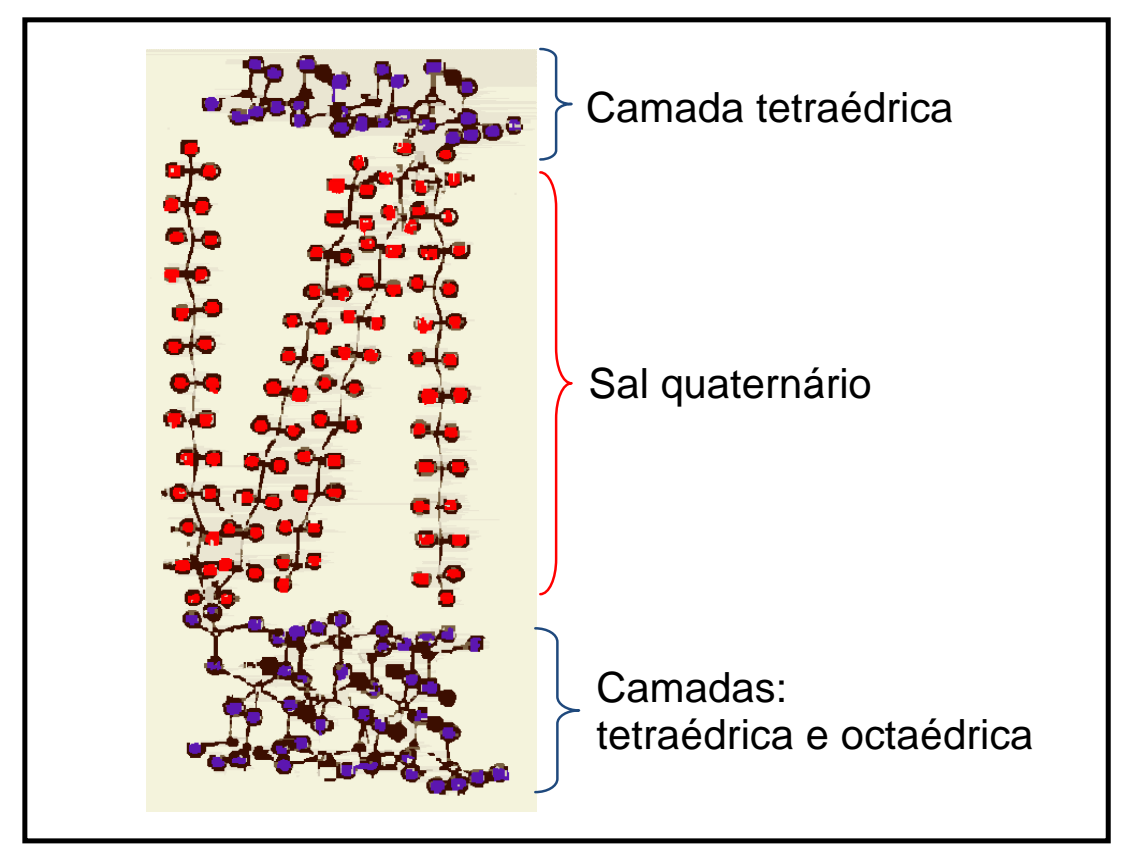

Figura 2.7.1 - Representação do cátion do sal quaternário de amônio na estrutura da bentonita. Adaptada de Vieira José, et al. [2002].

As argilas organofílicas têm sido sintetizadas a partir de bentonita sódica, que é altamente hidrofílica [SHARMASARKAR; JAYNES; VANCE, 2000] e pela adição de sais quaternários de amônio (com ao menos uma cadeia contendo 12 ou mais átomos de carbono) a dispersões aquosas de argilas esmectíticas sódicas. Nestas dispersões aquosas as partículas da argila devem encontrar-se em elevado grau de delaminação, isto é, as partículas elementares da argila, que são lamelas, devem encontrar-se (em maior ou menor grau) umas separadas das outras (e não empilhadas), facilitando a introdução dos compostos orgânicos, que as irão tornar organofílicas [VALENZUELA DÍAZ, 1994, VALENZUELA DÍAZ, 1999, VALENZUELA DÍAZ, 2001]. Nestas dispersões aquosas de bentonitas sódicas, os cátions orgânicos do sal substituem os cátions de sódio da bentonita sódica, passando de hidrofílica para organofílica [VIEIRA JOSÉ, et al., 2002].

Devido à afinidade que possuem por compostos orgânicos, as argilas organofílicas estão sendo largamente estudadas na adsorção e retenção de resíduos perigosos, industriais e contaminantes sólidos [VIEIRA JOSÉ, et al., 2002, RAMOS VIANNA, et al., 2002]. Podendo ser usadas no tratamento de águas contaminadas, sendo ainda indicadas para revestimentos de reservatórios de disposição de resíduos [SHENG; BOYD, 1998], tratamento de efluentes, 
derramamento controlado, em tanques de óleos ou gasolina e em revestimentos de aterros [ZHANG; SPARKS; SCRIVNER, 1993].

Estas argilas organofílicas apresentam a propriedade de inchar em solventes orgânicos específicos [VALENZUELA DÍAZ, 1999] e o comportamento das argilas nesses sistemas é descrito por Laba [1993]: a parte catiônica das moléculas do sal quaternário de amônio ocupa os sítios onde anteriormente estavam os cátions sódio e as longas cadeias orgânicas se situam entre as camadas do argilomineral.

Desfrutam de um grande número de aplicações nas diversas áreas tecnológicas [FRANCA; BÜCHLER, 1998]. Tem grande utilidade como componentes tixotrópicos de fluidos de perfuração de poços de petróleo à base de óleo; nas indústrias de fundição de metais, lubrificantes, tintas, adesivos e cosméticos, e no controle do meio-ambiente [VALENZUELA DÍAZ, 1994, VIEIRA JOSÉ et al., 2002, LABA, 1993, PINTO, 2001, RAMOS VIANNA, 2001].

Segundo Lagaly [1982] e Jaynes e Boyd [1991], dependendo do arranjo do cátion orgânico na região interlamelar das argilas bentoníticas, as argilas organofílicas podem ter espaçamentos basais de $\sim 1,37 \mathrm{~nm}, \sim 1,77 \mathrm{~nm}, \sim 2,17 \mathrm{~nm}$ e $>2,2 \mathrm{~nm}$, conforme um meio orgânico, respectivamente, com monocamada, bicamada, camada pseudotrimolecular e um complexo parafínico, conforme Figura 2.7.2.

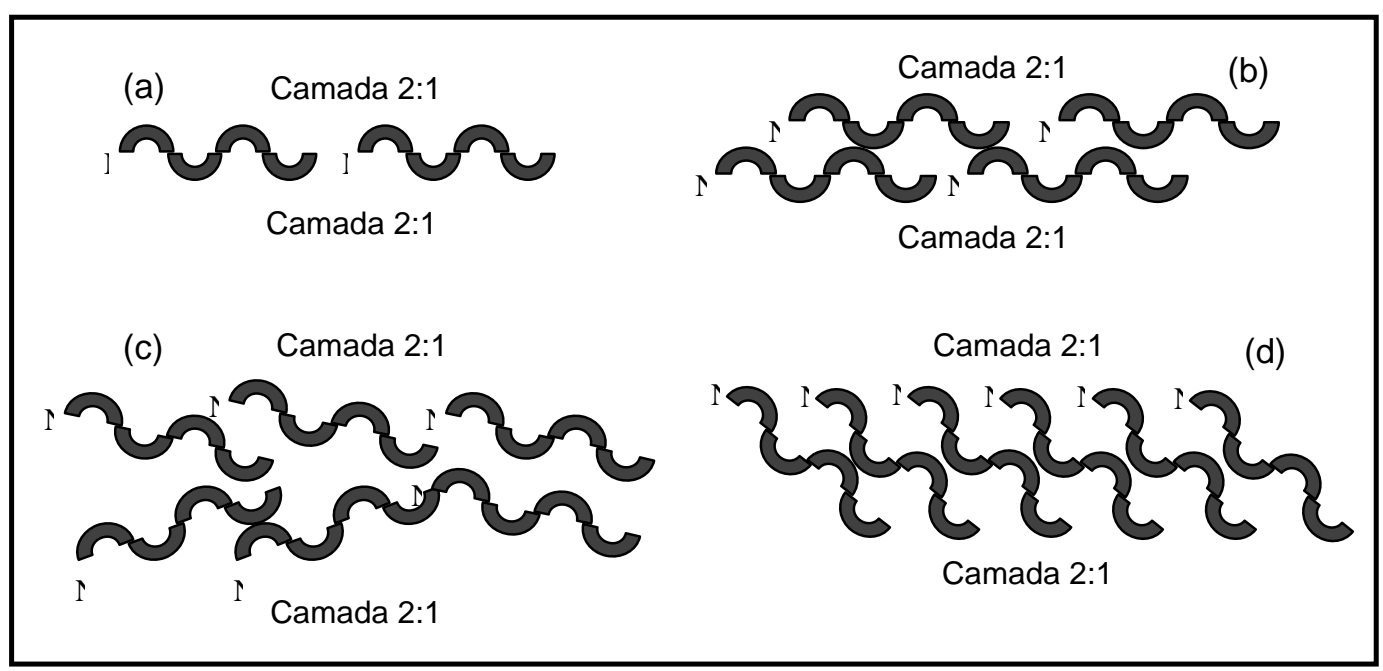

Figura 2.7.2 - Arranjo dos cátions orgânicos na região interlamelar das argilas organofílicas: (a) monocamada, (b) bicamada, (c) camada pseudotrimolecular e (d) complexo parafínico. Adaptado de Ramos Vianna [2005]. 
No Laboratório de Matérias-Primas Particuladas e Sólidos Não Metálicos do Departamento de Engenharia Metalúrgica e de Materiais da Escola Politécnica da Universidade de São Paulo (LMPSol/PMT/EPUSP) tem sido sintetizadas e caracterizadas diversas argilas organofílicas, usando-se várias argilas esmectíticas brasileiras [VALENZUELA DÍAZ, 1994, VALENZUELA DÍAZ, 2001, VALENZUELA DÍAZ; et al., 1998].

As argilas organofílicas vêm ganhando notoriedade, dado estarem sendo utilizadas na obtenção de nanocompósitos bentonitas/polímeros, um novo tipo de material com amplo potencial de uso, principalmente, nas indústrias automotivas e de embalagens [PINNAVAIA; BEAL, 2001]. 
argilasativaçaoquimicaorganofiliza

ãoesmectíticasbentonitasestudoácił

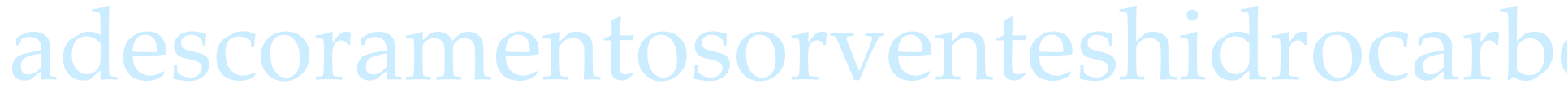

\section{Capítulo 3}

\section{Materiais e métodos}

A seguir serão apresentados os materiais utilizados e a metodologia adotada no desenvolvimento da Tese.

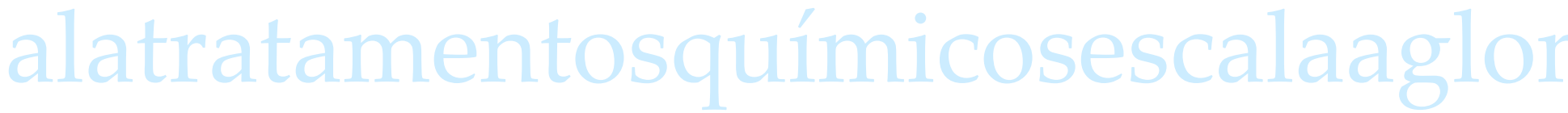

eradoslocalizadasreaçãotempossai quaternáriosespectroscopiadescor: mentoorganofílicastabelasgráficosr etodologiaresultadosativaçãobofer alizaçãoteseartigosespectrofotomet agasolinaclorídricolaboratórioutiliz çãoindústrialcientíficociênciabofeo 


\subsection{Materiais}

\subsubsection{Amostras}

Foram utilizadas quatro amostras de bentonita do tipo Bofe, provenientes da cidade de Boa Vista/PB; fornecidas na forma natural (não beneficiada), por indústria beneficiadora da região, cada uma retirada em depósitos de tipos diferentes e avaliadas pelo Engenheiro da empresa como representativas dos depósitos em questão. Foram fornecidos aproximadamente $2 \mathrm{~kg}$ de cada amostra.

A pedido da empresa, os nomes comerciais das amostras não serão divulgados e as mesmas foram denominadas de:

$>\mathrm{A}$

$>\mathrm{B}$

$>\mathrm{C}$

$\mathrm{D}$

Dado as amostras terem sido fornecidas na forma de fragmentos com diâmetro variando de 1 a $8 \mathrm{~cm}$, inicialmente foram desagregadas em almofariz (não foi necessária a secagem), sendo em seguida moídas em moinho de bola vibratória marca MLW, modelo KM1, até passagem completa em peneira ABNT 200 (abertura $0,074 \mathrm{~mm})$.

\subsubsection{Compostos utilizados}

Hidróxido de sódio, solução aquosa a 50\% *

Acetato de amônio $3 \mathrm{M}$ **

$>$ Fenolftaleína **

$>$ Ácido bórico, solução aquosa a $4 \%$ **

$>$ Ácido clorídrico $0,1 \mathrm{~N}$ **

$>$ Ácido clorídrico $6 \mathrm{M}$ *** 
Carbonato de sódio P.A *

Sais quaternários de amônio (Sal 1: cloreto de hexadecil trimetil amônio, com predominância de $\mathrm{C}_{16}$; Sal 2: cloreto de alquil trimetil amônio, com predominância de $\mathrm{C}_{12}$ e Sal 3: cloreto de cetil piridínio, com predominância de $\mathrm{C}_{17}$. Os sais são produtos comercias e as amostras foram gentilmente fornecidas pela Clariant Brasil)

> Óleo de soja não refinado de empresa beneficiadora de óleo de soja, sendo fornecido como amostra no estágio anterior ao descoramento com argila.

$\mathrm{n}$-Hexano P.A *

Gasolina comercial não aditivada

Diesel comercial não aditivado

Querosene comercial

Tolueno P.A ****

$>$ Álcool etílico P.A

$>$ Álcool metílico P.A *

$>$ Acetona P.A ****

$>$ Água destilada

* - Marca Synth

** - Marca Haloquímica

*** - Marca Vetec

$* * * *$ - Marca Nuclear

$* * * * \star$ - Marca Caal

\subsection{Determinação da Capacidade de Troca de Cátions (CTC)}

Para determinação da Capacidade de Troca de Cátions (CTC) foi utilizado um destilador de Kjeldahl (Figura 3.2.1) da marca Marconi, modelo MA-036Plus, do Laboratório de Matérias-Primas Particuladas e Sólidos Não-Metálicos do Departamento de Engenharia Metalúrgica e de Materiais da Escola Politécnica da Universidade de São Paulo (LMPSol/PMT/EPUSP). 


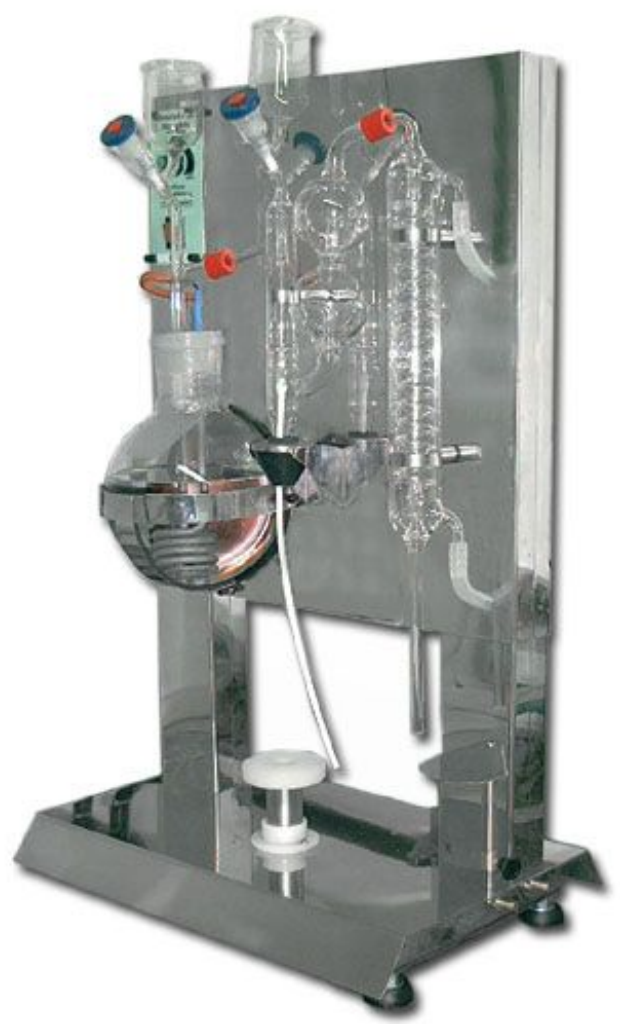

Figura 3.2.1 - Aparelho de Kjeldahl. Adaptado de Botelho [2006].

Inicialmente pesou-se, em balança analítica, 5,0 gramas da amostra que foi transferida para um erlenmeyer que continha $200 \mathrm{~mL}$ de acetato de amônio 3M, em seguida colocou-se o erlenmeyer com a solução em agitador magnético e deixou-se sob agitação constante por 12 horas.

Após este período centrifugou-se para coletar apenas a amostra, que foi lavada com álcool etílico para retirar o excesso de acetato de amônio e centrifugada novamente. O material recolhido foi transferido para um vidro de relógio e permaneceu em estufa à $60^{\circ} \mathrm{C} \pm 5^{\circ} \mathrm{C}$ por 24 horas para secagem.

Após seco, pesou-se em balança analítica 1,5 gramas do material, que foi desagregado manualmente em almofariz e transferido para um frasco de Kjeldahl adicionando-se $50 \mathrm{~mL}$ de água destilada e 3 gotas de fenolftaleína e acoplou-se o frasco no aparelho. O esquema da destilação de Kjeldahl é mostrado na Figura 3.2.2. 


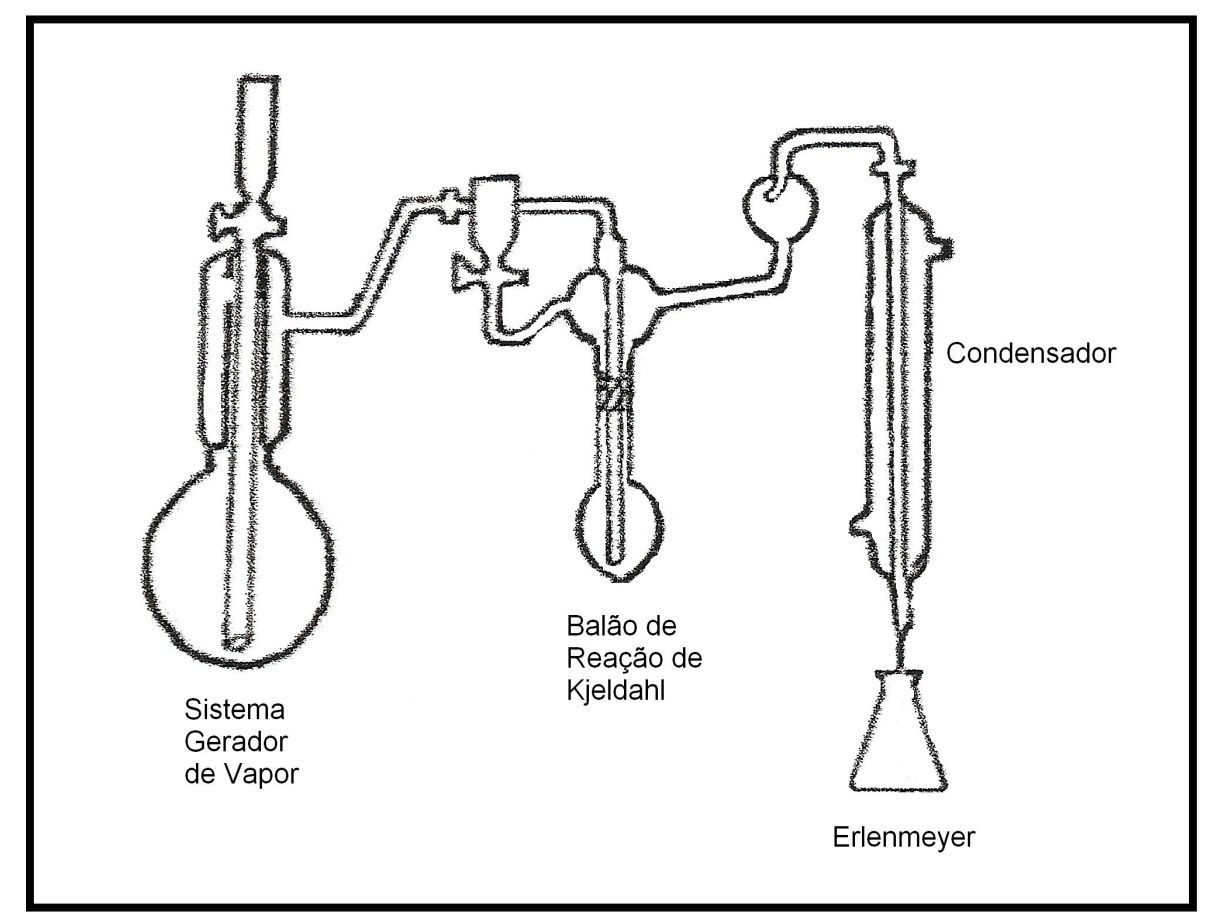

Figura 3.2.2 - Esquema de destilação de Kjeldahl. Adaptado de Botelho [2006].

Adicionou-se hidróxido de sódio a $50 \%$ até a solução contida no frasco de Kjeldahl tornar-se rósea. Após isto, injetou-se vapor ao tubo, ocorrendo a liberação da amônia. $\mathrm{O} \mathrm{NH}$ desprendido é passado por um destilador e é então recebido em um erlenmeyer contendo $50 \mathrm{~mL}$ de ácido bórico a $4 \%$ com indicador misto (vermelho de metila a $0,50 \%$ e verde de bromocresol a $0,75 \%$ em álcool etílico). O tempo de destilação foi de aproximadamente 10 minutos. $\mathrm{O}$ ácido bórico com indicador que, no início apresentava coloração vermelha, adquire cor verde à medida que vai recebendo $\mathrm{NH}_{3}$.

Encerrada a destilação, retirou-se o erlenmeyer do sistema e procedeu-se a titulação da solução com ácido clorídrico $0,1 \mathrm{~N}$ até viragem da coloração, obteve-se novamente a coloração vermelha. Anotou-se então o volume $(\mathrm{em} \mathrm{mL})$ gasto na titulação.

Para a determinação da CTC é utilizada a seguinte expressão:

$$
C T C=\frac{N \times f \times V_{H C l} \times 100}{M}
$$


Onde:

> CTC - Capacidade de Troca de Cátions

$\mathrm{N}$ - normalidade do $\mathrm{HCl}=0,1 \mathrm{~N}$

$>\mathrm{f}-$ fator de conversão do ácido $=1$

$>\mathrm{V}_{\mathrm{HCl}}$ - volume de $\mathrm{HCl}$ gasto na titulação $(\mathrm{mL})$

$>\mathrm{M}=$ massa da amostra $(\mathrm{g})$

\subsection{Parte experimental}

As atividades experimentais envolveram duas etapas. A primeira é o estudo da ativação ácida e a segunda parte é da preparação de argilas organofílicas, descritas a seguir:

\subsection{1 - 1ª parte: Ativação ácida}

\subsubsection{Metodologia}

A Figura 3.3.1.1.1 apresenta o fluxograma da metodologia aplicada na ativação ácida. 


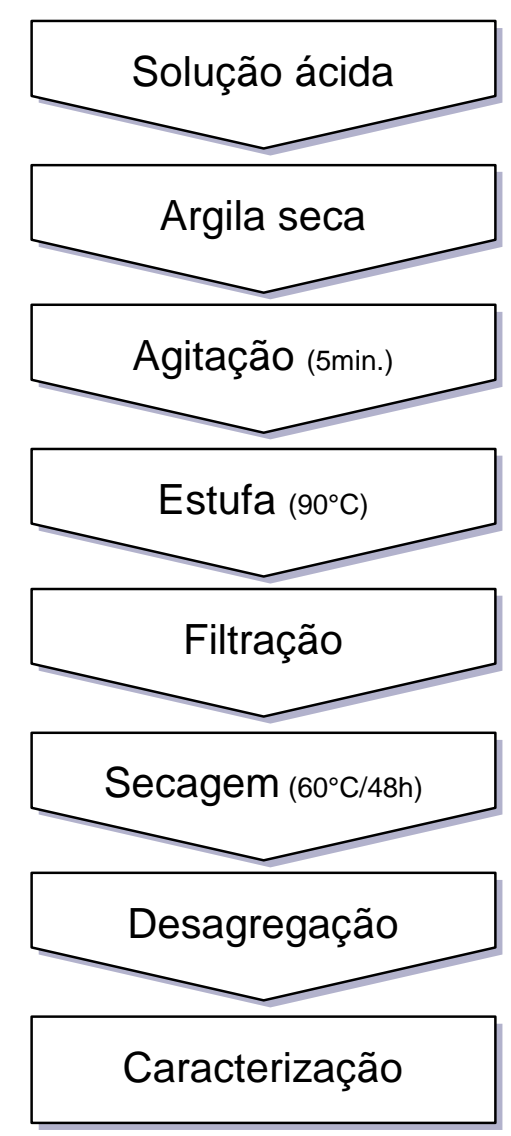

Figura 3.3.1.1.1 - Fluxograma da metodologia da ativação ácida.

A ativação foi efetuada com ácido clorídrico $(\mathrm{HCl})$, e as condições de ataque foram:

Temperatura $=90^{\circ} \mathrm{C}$

Tempo = 1, 2 e 3 horas; 1, 2, 3, 4, 5, 6 e 7 dias

> Concentração do ácido $=6 \mathrm{M}$

Relação massa argila / volume solução $=1 \mathrm{~g} / 10 \mathrm{~mL}$

Inicialmente foram preparadas soluções aquosas 6M com o ácido clorídrico $(\mathrm{HCl})$, a qual foi adicionada sobre a amostra (seca e moída), que estava contida em recipiente de vidro. Em seguida as misturas foram agitadas manualmente, tampouse com tampa de polipropileno e as dispersões foram levadas à estufa à temperatura de $90^{\circ} \mathrm{C} \pm 5^{\circ} \mathrm{C}$, para aquecimento. Após o tempo de reação, as misturas obtidas foram filtradas à vácuo (Funil de Büchner e Kitassato) e lavadas com água destilada 
até que o $\mathrm{pH}$ dos filtrados ficasse em torno do $\mathrm{pH}$ da água utilizada para lavagem. $\mathrm{O}$ material obtido foi seco em estufa à temperatura de $60^{\circ} \mathrm{C} \pm 5^{\circ} \mathrm{C}$. Após 48 horas, os materiais obtidos foram desagregados em almofariz manual e caracterizados.

As condições de realização da ativação ácida foram baseadas em estudo efetuado com uma amostra de argila Brasgel sódica e uma amostra de bentonita de cor verde-lodo, policatiônica, de Boa Vista, Paraíba, no qual se constatou ser mais conveniente adicionar a solução ácida sobre a amostra seca e na forma de pó do que sobre dispersão aquosa, dado que neste último caso os tempos de filtração foram muito longos [VALENZUELA DÍAZ, 1994].

\subsubsection{Teste de descoramento de óleo}

Realizou-se com a amostra ativada o teste de descoramento em óleo de soja, que foi realizado de acordo com o procedimento de $20 \mathrm{~mL}$ descrito por Valenzuela Díaz [2000], e consiste das seguintes etapas:

a) $20 \mathrm{~mL}$ do óleo foram colocados em frasco de vidro e acrescentou-se $0,75 \mathrm{~g}$ de argila, homogeneizando-se com bastão de vidro;

b) colocou-se em estufa a $90^{\circ} \mathrm{C}$ por 48 horas

c) após resfriamento, procedeu-se a leitura de absorbância.

A eficiência do descoramento é dada por: $\left[\left(A_{440}\right.\right.$ óleo impuro $-A_{440}$ óleo puro $) / A_{440}$ óleo impuro] * 100, onde:

> $\mathrm{A}_{440}$ óleo impuro - absorbância do óleo impuro à 440nm.

$>\mathrm{A}_{440}$ óleo puro - absorbância do óleo puro à 440nm.

* 440nm foi escolhida por ser a máxima absorbância.

As amostras de óleo antes e após o descoramento foram analisadas em espectrofotômetro de absorção marca Varian, modelo CARY-50-PROBE, varrendo os comprimentos de onda na faixa de 300 a 700 nanômetros. O equipamento 
pertence ao Laboratório de Fotoquímica do Departamento de Engenharia Química da Escola Politécnica da Universidade de São Paulo (PQI/EPUSP).

Como referência foram utilizadas, neste teste, argilas ativadas comerciais: Tonsil (fornecida pela Süd-Chemie) e Alclor (fornecida pela Alclor) pertencentes à coleção de argilas do LMPSol.

\subsection{2 - 2ª parte: Preparação de argilas organofílicas}

Esta segunda parte do estudo é designada à preparação de argilas organofílicas. As amostras foram submetidas a procedimento de troca cationica por sódio, utilizando-se carbonato de sódio. Partindo-se da amostra sódica, as argilas organofílicas foram obtidas a partir de três sais quaternários de amônio, estes sais possuem um ou dois grupos de hidrocarbonetos de cadeia longa. As amostras preparadas foram denominadas da seguinte maneira:

OA1 - argila A preparada com o sal 1.

> OB1 - argila B preparada com o sal 1.

> OC1 - argila C preparada com o sal 1.

$>$ OD1 - argila D preparada com o sal 1.

e assim sucessivamente (a letra indica a amostra e a numeração o sal).

\subsubsection{Metodologia}

A Figura 3.3.2.1.1 apresenta o fluxograma de preparação. 


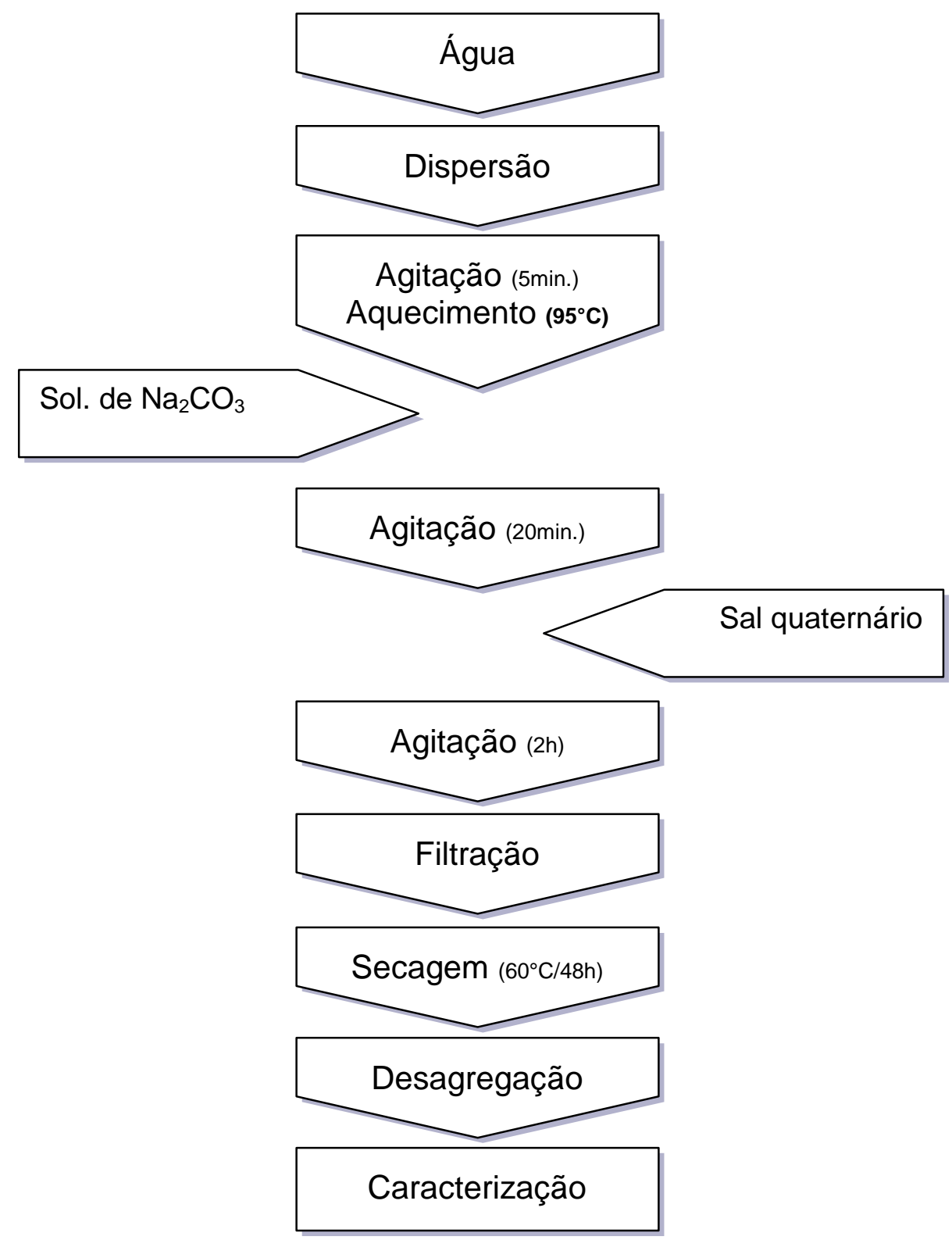

Figura 3.3.2.1.1 - Fluxograma de preparação de argilas organofílicas.

A metodologia de obtenção das argilas organofílicas foi baseada em estudo realizado por Valenzuela Diaz [1994] e modificado por Pereira [2003]. Inicialmente foi preparada uma dispersão aquosa à concentração de $4 \%$ em peso de argila desagregada e moída. A dispersão foi preparada adicionando-se a argila, aos poucos e com agitação mecânica constante, em recipiente de vidro contendo água destilada e após adição da amostra a agitação foi continuada por 20 minutos. Acrescentou-se à dispersão aquosa, solução de carbonato de sódio a $20 \%$, sob agitação constante e aquecimento até 95-97º [ [VALENZUELA DÍAZ, 1994]. 
Após ebulição e resfriamento, agitou-se mecanicamente a mistura e acrescentou-se solução de sal quaternário de amônio na proporção de $80 \mathrm{meq} / 100 \mathrm{~g}$ de argila seca, aos poucos, após adição completa do sal quaternário, continuou-se a agitação por 2 horas e após este período a dispersão foi filtrada em funil de Büchner acoplado a bomba à vácuo, usando-se papel de filtro comum. O material foi lavado sucessivamente com água destilada. Ao término da filtração, o material obtido foi seco em estufa a $60^{\circ} \mathrm{C} \pm 5^{\circ} \mathrm{C}$ por 48 horas e caracterizado.

\subsubsection{Teste de Inchamento}

O teste de inchamento de Foster é utilizado para verificar a afinidade do sal quaternário com as moléculas orgânicas dos solventes e foi realizado segundo Valenzuela Díaz [1994].

O ensaio consistiu em adicionar, lentamente e sem agitar, 1,00 g de argila a $50 \mathrm{~mL}$ do solvente contido em proveta graduada. Após 24 horas de repouso mediuse o volume ocupado pela argila (inchamento sem agitação) e agitou-se o conteúdo da proveta, com bastão de vidro, por 5 minutos. Após 24 horas de repouso, mediuse novamente o volume ocupado pela argila (inchamento com agitação).

Os solventes utilizados neste teste foram: gasolina, diesel, querosene, tolueno, acetona, álcool etílico e álcool metílico.

\subsubsection{Teste de sorção}

O teste de sorção foi baseado nas normas ASTM F716-82 e ASTM F726-99, sendo realizado com hidrocarbonetos derivados do petróleo. Os solventes testados foram: gasolina, querosene, diesel e tolueno.

O teste foi realizado da seguinte maneira: inicialmente pesou-se $1,0 \mathrm{~g}$ da amostra e colocou-se em "cestinha" metálica (construída a partir de tela de aço inox com malha ABNT 200 (abertura 0,075mm)) de peso conhecido, este conjunto permaneceu por 15 minutos em recipiente que continha o solvente. Após este 
período ergueu-se a "cestinha" por 15 segundos e pesou-se o conjunto. A diferença de peso inicial e final indica o que foi sorvido pela amostra.

\subsection{Caracterização}

Caracterizar uma argila, especialmente visando seu uso tecnológico, é conhecer a variabilidade de suas propriedades, o que não é tão simples, pois, é necessário o emprego de técnicas não apenas comuns, como também as mais trabalhosas e as mais sofisticadas [SOUZA SANTOS, 1989].

Todas as técnicas fornecem informações que se completam. Dentre os diversos métodos empregados na caracterização, a seguir serão apresentados os que foram utilizados nesta tese.

\subsubsection{Difração de Raios-X (DRX)}

A Difração de Raios-X (DRX) é a técnica que fornece informações mais amplas, precisas e detalhadas quanto à qualificação, caracterização e quantificação dos constituintes presentes numa argila, além disso, é uma técnica de análise não destrutiva, rápida e muito versátil, tendo apenas o obstáculo de não se poder aplicar a minerais não cristalinos ou com cristalinidade incipiente. Nas argilas o número destes minerais é pouco significativo [GOMES, 1988].

Foi utilizado o método de varredura, que consiste na incidência dos raios-X sobre uma amostra em forma de pó, compactado sobre um suporte. $\mathrm{O}$ aparelho utilizado é da marca Philips X'PERT MPD com radiação Ka do cobre, tensão de $40 \mathrm{KV}$, corrente de 40mA, tamanho do passo de $0,0202 \Theta$ e tempo por passo de 1,000s, pertencente ao Laboratório de Matérias-Primas Particuladas e Sólidos NãoMetálicos do Departamento de Engenharia Metalúrgica e de Materiais da Escola Politécnica da Universidade de São Paulo (LMPSol/PMT/EPUSP). 


\subsubsection{Espectroscopia na Região do Infravermelho}

As bandas de absorção que surgem nos espectros na região do infravermelho de argilas, minerais argilosos ou outros minerais devem-se à excitação das vibrações atômicas sempre que a radiação infravermelha tem a mesma energia ou freqüência destas vibrações, que correspondem quer a movimentos de translação, quer a movimentos de rotação dos átomos ou moléculas [ULLMANN'S, 1986].

Embora o espectro na região do infravermelho seja característico da molécula como um todo, certos grupos de átomos dão origem a bandas que ocorrem na mesma freqüência, independente da estrutura da molécula. É justamente a presença destas bandas características de grupos que permite ao analista a obtenção, através de simples exame do espectro e consulta de tabelas, informações estruturais úteis [ARROYO, 1992].

As posições das bandas nos espectros na região do infravermelho são apresentadas em comprimento de onda, ou número de onda. $O$ mícron $\left(1 \mu=10^{-6} \mathrm{~m}\right)$ costumava ser a unidade habitual para descrever as bandas de absorção na espectrometria na região do infravermelho. Atualmente prefere-se utilizar a unidade número de onda $\left(\mathrm{cm}^{-1}\right.$, centímetro recíproco, centímetro inverso) que é diretamente proporcional à energia. Muitos dos instrumentos mais novos e sofisticados são lineares em $\mathrm{cm}^{-1}$ [SILVERSTEIN; BASSLER; MORRIL, 1989].

As amostras foram analisadas em comprimentos de onda na faixa de 4000 a $400 \mathrm{~cm}^{-1}$, utilizando-se o método da reflectância difusa, através de analisador Espectrômetro FTIR MAGNA 560 ESPS Nicolet, do Laboratório de Processos Cerâmicos do Departamento de Engenharia Metalúrgica e de Materiais da Escola Politécnica da Universidade de São Paulo (LPC/PMT/EPUSP).

\subsubsection{Análises Térmicas: TG, DTG e DTA}

Análise térmica é um termo que abrange um grupo de técnicas nas quais uma propriedade física ou química de uma substância, ou de seus produtos de reação, é monitorada em função do tempo ou temperatura, enquanto a temperatura da 
amostra, sob uma atmosfera específica, é submetida a uma programação controlada [RAMOS VIANNA, 2005].

As análises térmicas formam realizadas em equipamento simultâneo de termogravimetria (TG) e análise térmica diferencial (DTA) da TA Instruments, modelo SDT Q600 do Departamento de Engenharia Química da Escola Politécnica da Universidade de São Paulo (PQI/EPUSP) e as condições de realização da análise foram:

Gás de purga: Nitrogênio.

Vazão do gás: $100 \mathrm{~mL} / \mathrm{min}$.

Taxa de aquecimento: $10^{\circ} \mathrm{C} / \mathrm{min}$.

Temperatura final: $1000^{\circ} \mathrm{C}$.

\subsubsection{Microscopia Eletrônica de Varredura (MEV)}

Nos últimos 15 anos, tem havido um grande desenvolvimento e aperfeiçoamento dos métodos e equipamentos ópticos-eletrônicos usados na caracterização de materiais sólidos, em especial os argilominerais em argilas e solos [SOUZA SANTOS, 1992].

A microscopia eletrônica é a técnica indicada para o estudo das formas dos cristais individuais dos minerais argilosos e permite o exame de superfícies, sendo adequada para o estudo de texturas [GOMES, 1988].

A amostra na forma de pó foi recoberta com uma fina camada de ouro (por ser bom condutor de elétrons) por um metalizador e fixada no porta amostra por uma fita adesiva de carbono. As micrografias foram obtidas no microscópio eletrônico de varredura da marca Philips, modelo XL30 EDAX do Laboratório de Microscopia Eletrônica e de Força Atômica do Departamento de Engenharia Metalúrgica e de Materiais da Escola Politécnica da Universidade de São Paulo (LabMicro/PMT/EPUSP). 


\section{CAPÍTULO 4}

\section{Resultados e discussão}

\section{Argilas Naturais}

O capítulo 4 apresenta os resultados obtidos na caracterização das argilas naturais. 


\subsection{Umidade inicial}

Para determinação da umidade foi utilizada a técnica tradicional (temperatura de $110^{\circ} \mathrm{C} / 24$ horas), também denominada de método direto, onde a água é retirada do produto, geralmente por processo de aquecimento, e o teor de umidade é calculado pela diferença de peso das amostras no início e ao final do processo. Esta diferença corresponde à quantidade de água retirada [PUZZI, 1986].

A Tabela 4.1.1 apresenta os valores de umidade das amostras A, B, C e D.

Tabela 4.1.1 - Umidade das argilas naturais.

\begin{tabular}{c|c}
\hline Amostra & Umidade (\%) \\
\hline A & 6,5 \\
B & 7,1 \\
C & 5,8 \\
D & 8,5 \\
\hline
\end{tabular}

As amostras apresentaram baixos valores de umidade, o qual é benéfico no processamento das mesmas, pois com os valores apresentados, elas ou podem ser submetidas a processos de moagem diretamente ou após serem submetidas a secagens leves e rápidas.

\subsection{Capacidade de troca de cátions (CTC)}

Para determinação da CTC, foi utilizado o método do acetato de amônio realizado em equipamento de Kjeldahl (descrito em 3.2.2) e os resultados da CTC das argilas naturais encontram-se na Tabela 4.2.1. 
Tabela 4.2.1 - Capacidade de troca de cátions (CTC) das argilas naturais.

\begin{tabular}{c|c}
\hline Amostra & CTC (meq/100g) \\
\hline A & 65 \\
B & 65 \\
C & 76 \\
D & 56 \\
\hline
\end{tabular}

As argilas esmectíticas da Paraíba apresentam geralmente valores de CTC entre 50 e 90meq $/ 100 \mathrm{~g}$ de argila [GRIM, 1968]. Os menores valores da faixa indicam que os argilominerais apresentam uma alta quantidade de impurezas ou um baixo nível de substituições isomórficas. Os valores relativamente baixos obtidos deverão servir de guia para futuros estudos, a serem realizados no LMPSol, visando obter argilas sódicas que apresentem altos valores, em água, de inchamento e/ou viscosidades, partindo-se de argilas tipo Bofe.

\subsection{Difração de Raios-X (DRX)}

As Figuras 4.3.1, 4.3.2, 4.3.3 e 4.3.4 apresentam as curvas de difração de raios- $X$, obtidas pelo método do pó, das amostras naturais $A, B, C$ e $D$, respectivamente. 


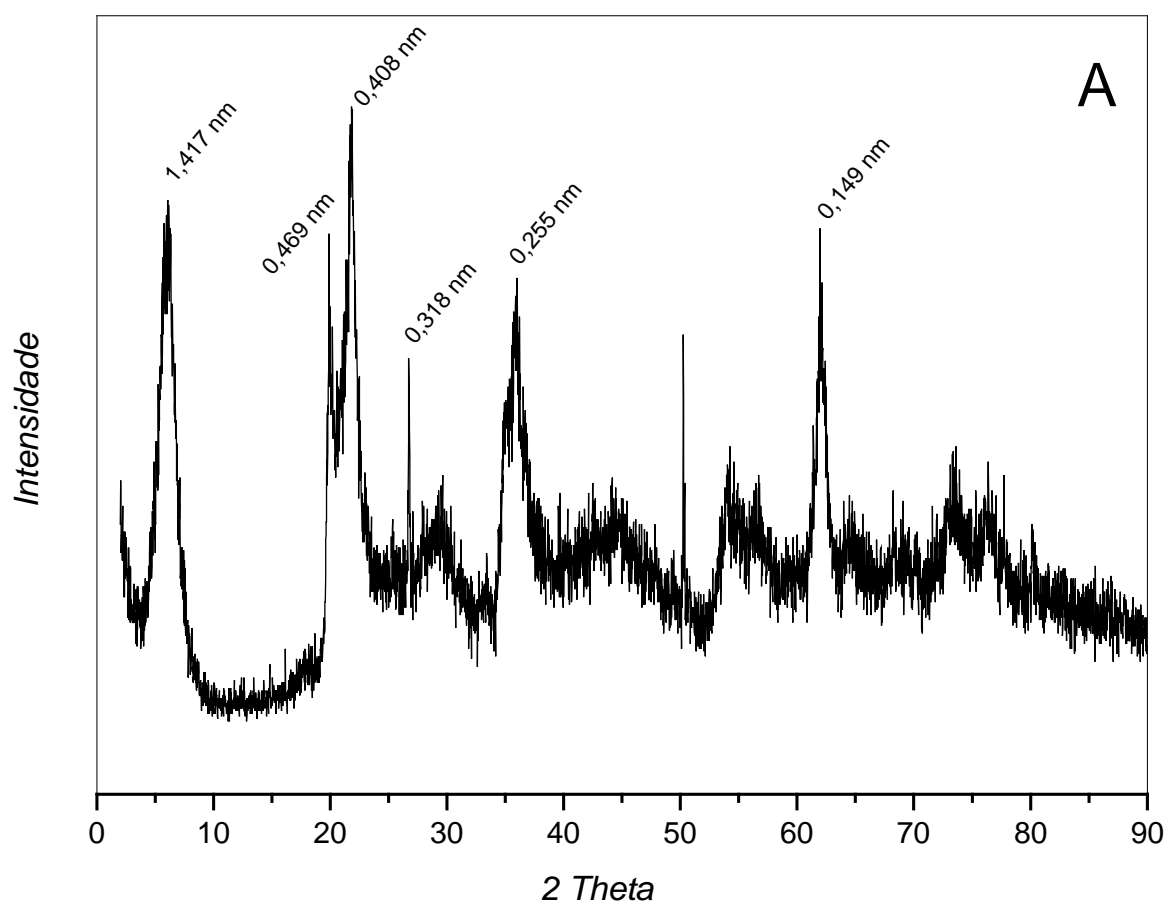

Figura 4.3.1 - Difratograma da amostra A.

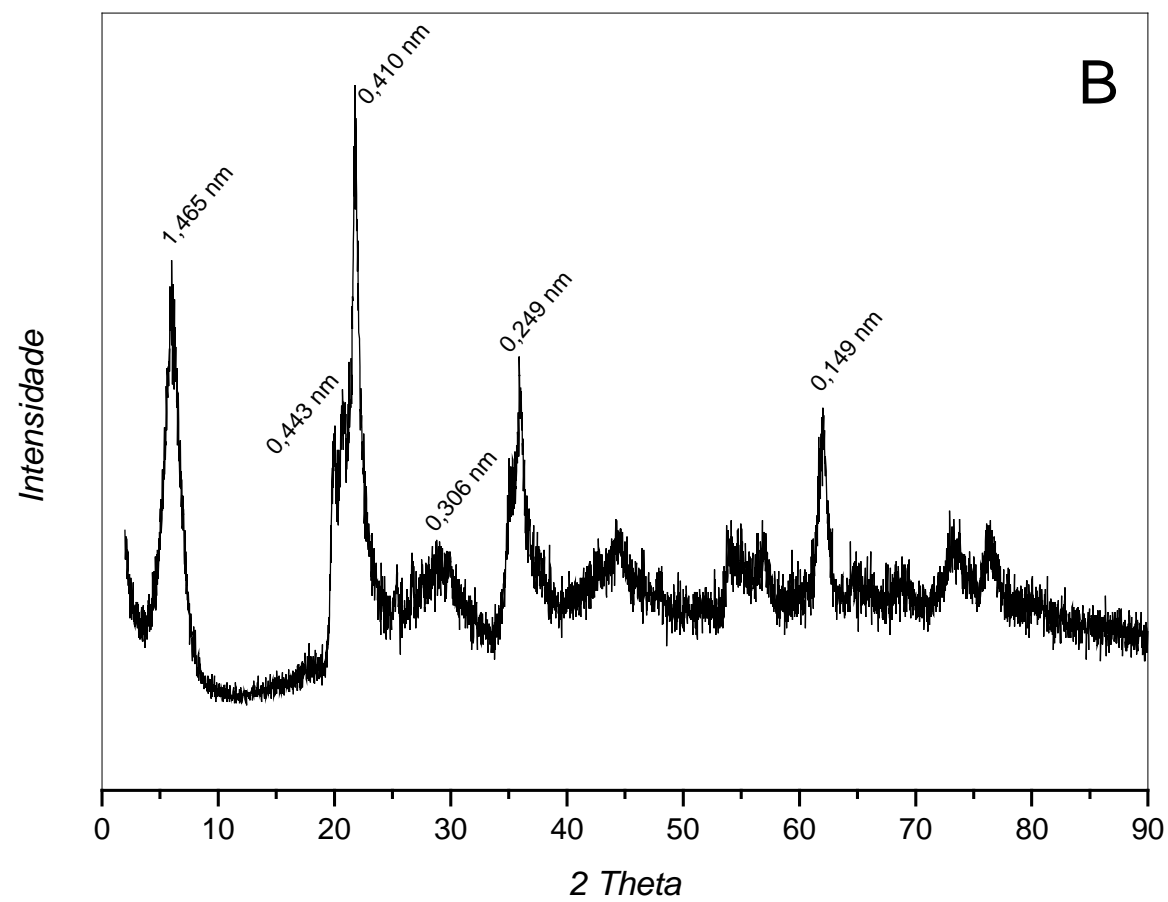

Figura 4.3.2 - Difratograma da amostra B. 


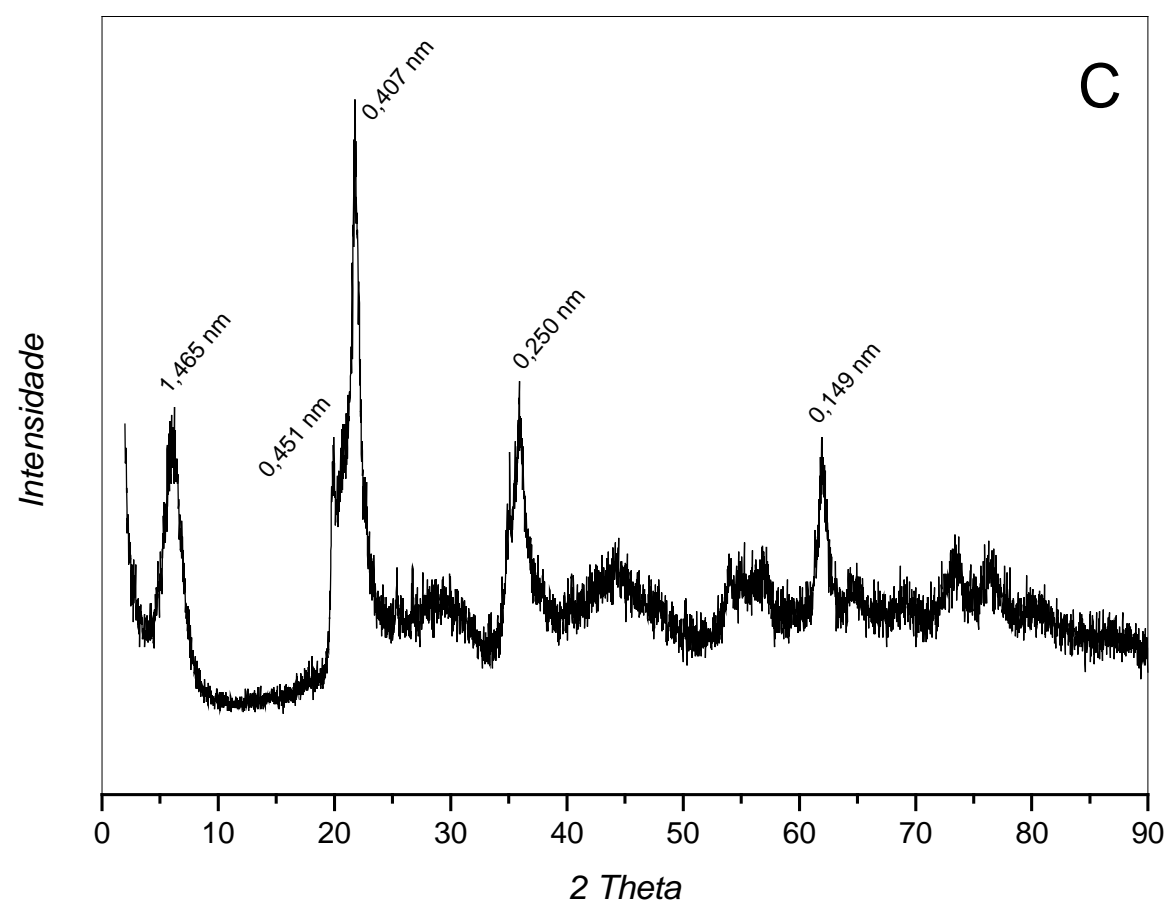

Figura 4.3.3- Difratograma da amostra C.

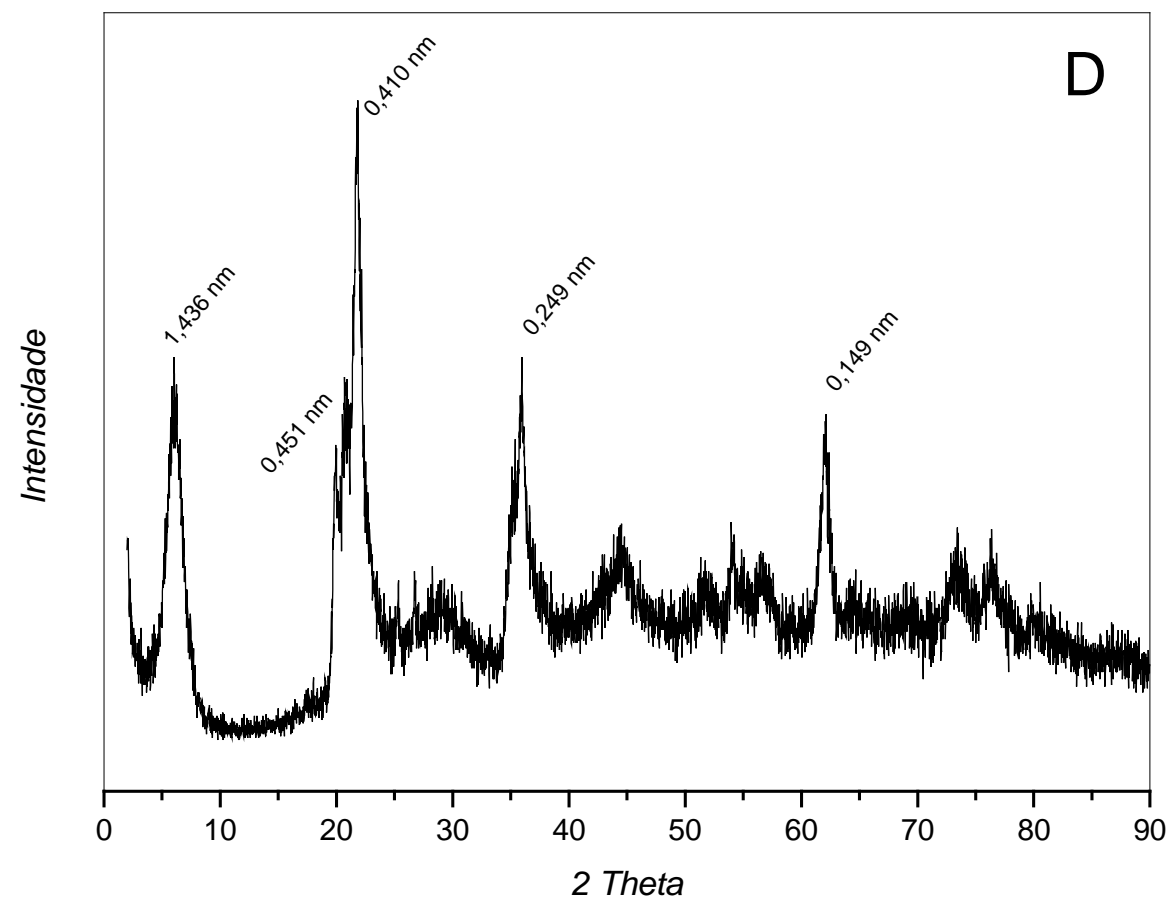

Figura 4.3.4 - Difratograma da amostra D. 
A caracterização das amostras por difração de raios- $X$, visa verificar a existência de minerais acessórios e de argilominerais. Observa-se que as amostras naturais evidenciam a intensidade mais alta dos picos característicos de argilas do tipo esmectítico e se encontram dentro da faixa apresentada pelos argilominerais desse grupo [GOMES, 1988]. As quatro amostras apresentaram o pico correspondente à distância interplanar $\mathrm{d}_{(001)}$ a aproximadamente $1,4 \mathrm{~nm}$, o que evidencia que mesmo tendo sido recolhidas em diferentes depósitos as mesmas, possivelmente, estejam constituídas do mesmo tipo de argilomineral. Nenhuma das quatro amostras apresentou pico na região dos $0,7 \mathrm{~nm}$, não tendo-se, assim argilominerais cauliníticos nas amostras tipo Bofe analisadas. Em nenhuma das quatro amostras foram observados picos a $1,0 \mathrm{~nm}$, o que evidencia a não existência de argilominerais micáceos nas amostras analisadas.

Observa-se a presença de outros picos nas faixas: $0,45 \mathrm{~nm}$ (correspondente ao argilomineral esmectítico); $0,41 \mathrm{~nm}$ (correspondente ao argilomineral esmectítico); $0,32 \mathrm{~nm}$ (correspondente ao quartzo); $0,25 \mathrm{~nm}$ (correspondente ao quartzo) e $0,149 \mathrm{~nm}$ (correspondente à distância basal $\mathrm{d}_{(060)}$ evidenciando que os argilominerais esmectíticos são dioctaédricos [VALENZUELA DÍAZ, 1994]. De uma forma geral os difratogramas das quatro amostras são similares, indicando que mesmo tratando-se de amostras recolhidas em depósitos diferentes, devem pertencer a uma mesma camada geológica.

Pereira et al. [2006] com o objetivo de realizar estudo das propriedades cerâmicas de 2 argilas provenientes da cidade de Boa Vista, Estado da Paraíba, verificaram a existência dos mesmos constituintes encontrados nas argilas deste trabalho, ou seja, picos característicos de argilominerais esmectíticos e outros picos referentes a mineral não esmectítico: como o quartzo.

\subsection{Espectroscopia na Região do Infravermelho (FTIR)}

Os espectros na região do infravermelho das amostras naturais estão apresentados nas Figuras 4.4.1, 4.4.2, 4.4.3 e 4.4.5. 


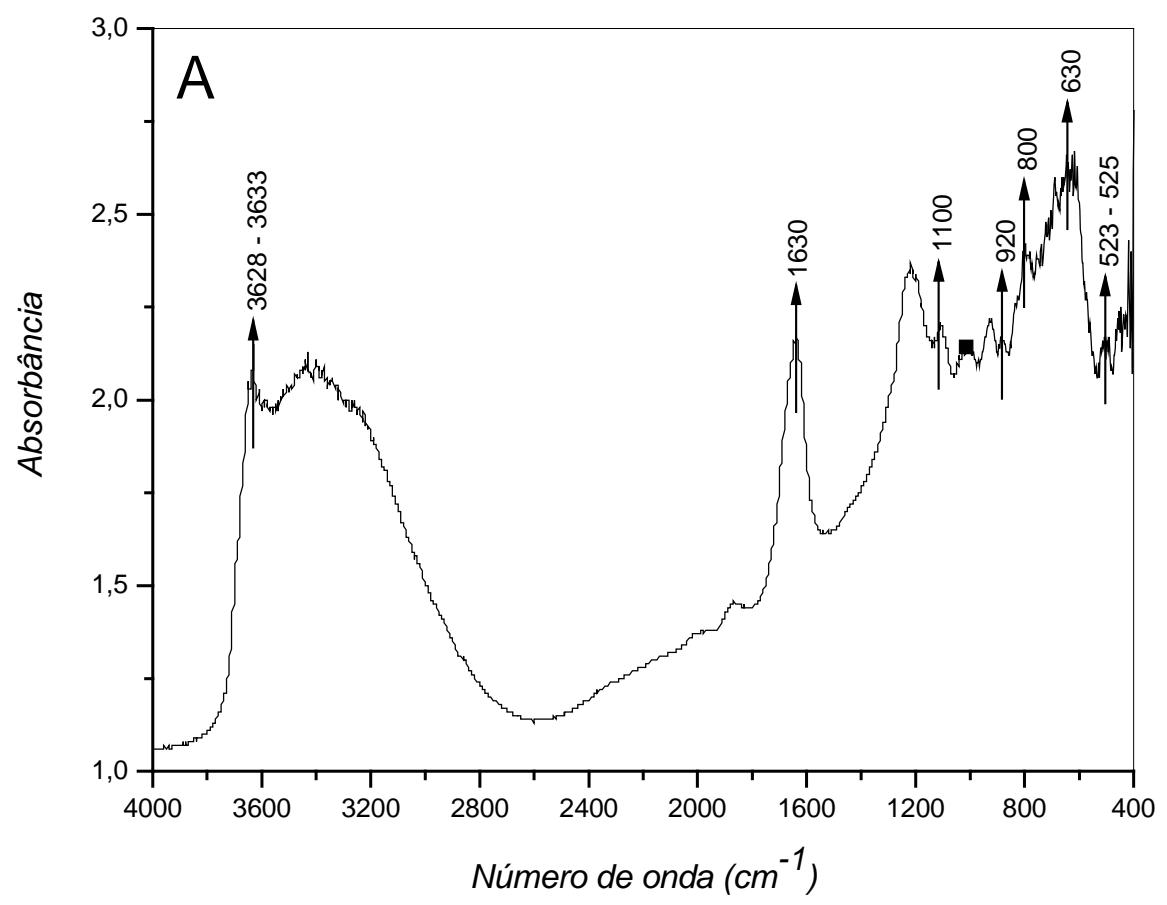

Figura 4.4.1 - Espectroscopia na região do infravermelho da amostra A.

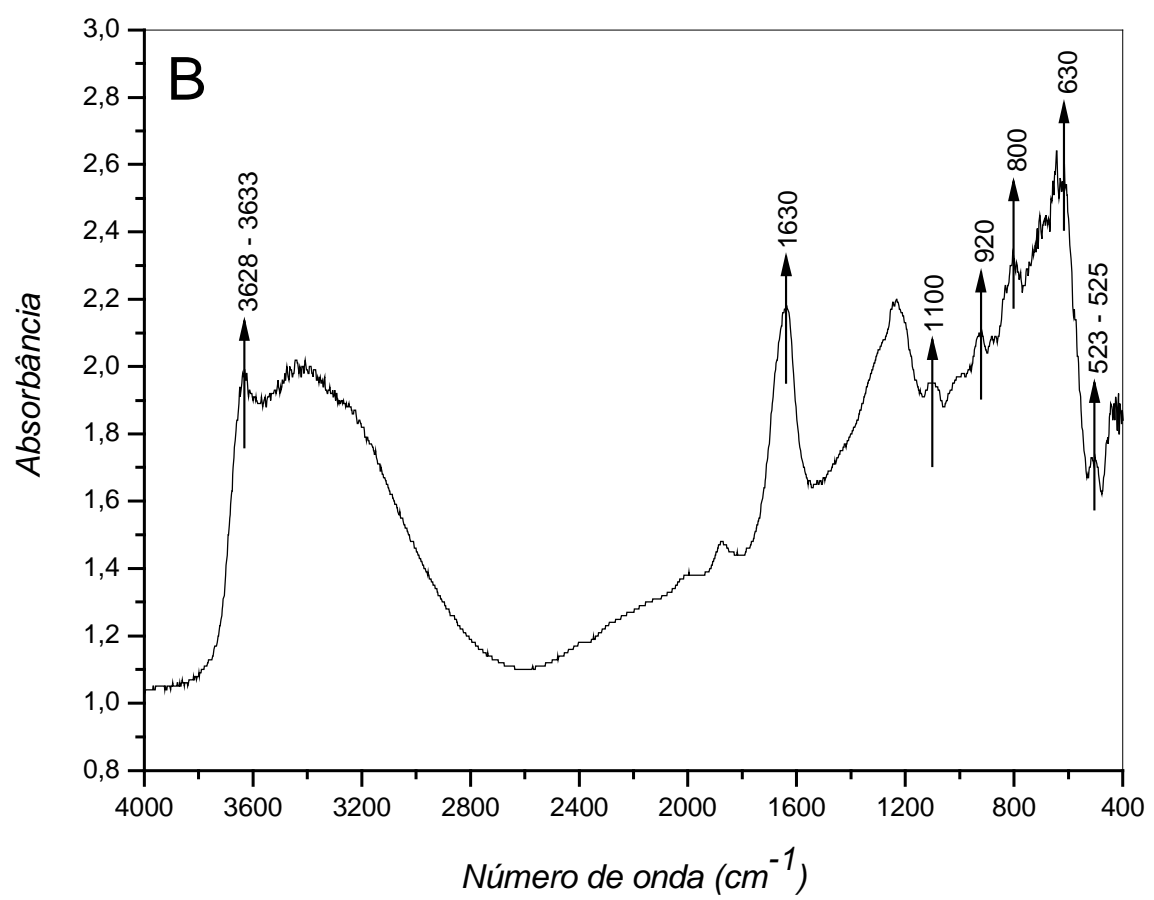

Figura 4.4.2 - Espectroscopia na região do infravermelho da amostra B. 


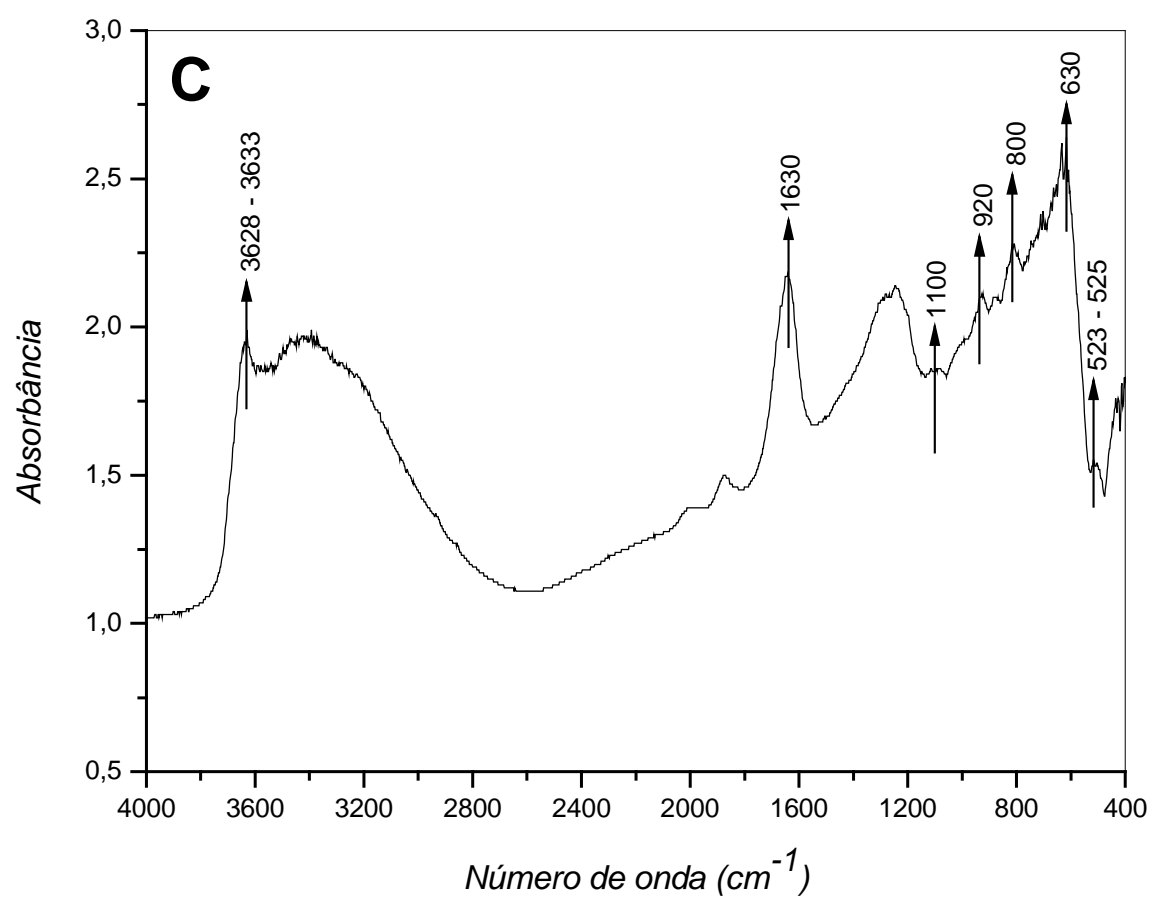

Figura 4.4.3 - Espectroscopia na região do infravermelho da amostra C.

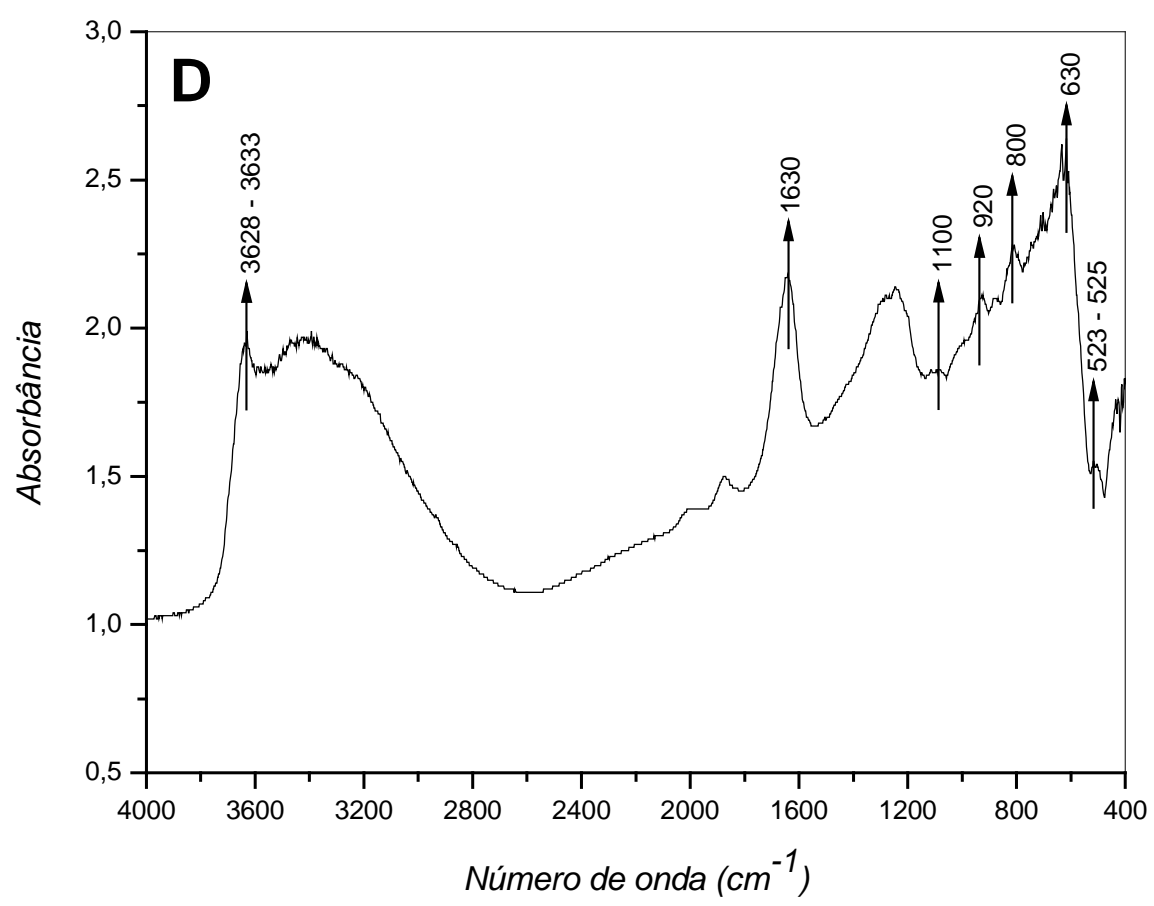

Figura 4.4.4 - Espectroscopia na região do infravermelho da amostra D. 
Nos espectros na região do infravermelho das amostras $A, B, C$ e D, verificase o aparecimento de bandas, que segundo Zhang, et al. [2003] e Bala; Samantaray; Srivastava [2000] são referentes a:

Bandas compreendidas entre $3633-3628 \mathrm{~cm}^{-1}$ e $1630 \mathrm{~cm}^{-1}$ são referentes as vibrações de estiramento do grupo O-H.

> Os picos característicos da ligação Si-O são freqüentes na faixa de 1100 $1040 \mathrm{~cm}^{-1}$ e $523-525 \mathrm{~cm}^{-1}$.

$\mathrm{Na}$ faixa de $630 \mathrm{~cm}^{-1}$ ocorre a ligação Al-O.

As camadas octaédricas são freqüentes nas faixas de $920 \mathrm{~cm}^{-1}, 800 \mathrm{~cm}^{-1} \mathrm{e}$ $525 \mathrm{~cm}^{-1}$.

A presença destes picos, em todas as amostras, indica características de argilas do tipo esmectítico, estando em conformidade com os difratogramas de raios$X$. De uma forma geral as curvas espectográficas na região do infravermelho das quatro amostras são similares, o que indica que mesmo tratando-se de amostras recolhidas em depósitos diferentes, devem pertencer a uma mesma camada geológica.

\subsection{Análises Térmicas: TG, DTG e DTA}

Os resultados das análises térmica das amostras naturais ( $A, B, C$ e D), estão apresentados na Figuras 4.5.1 a 4.5.4. 


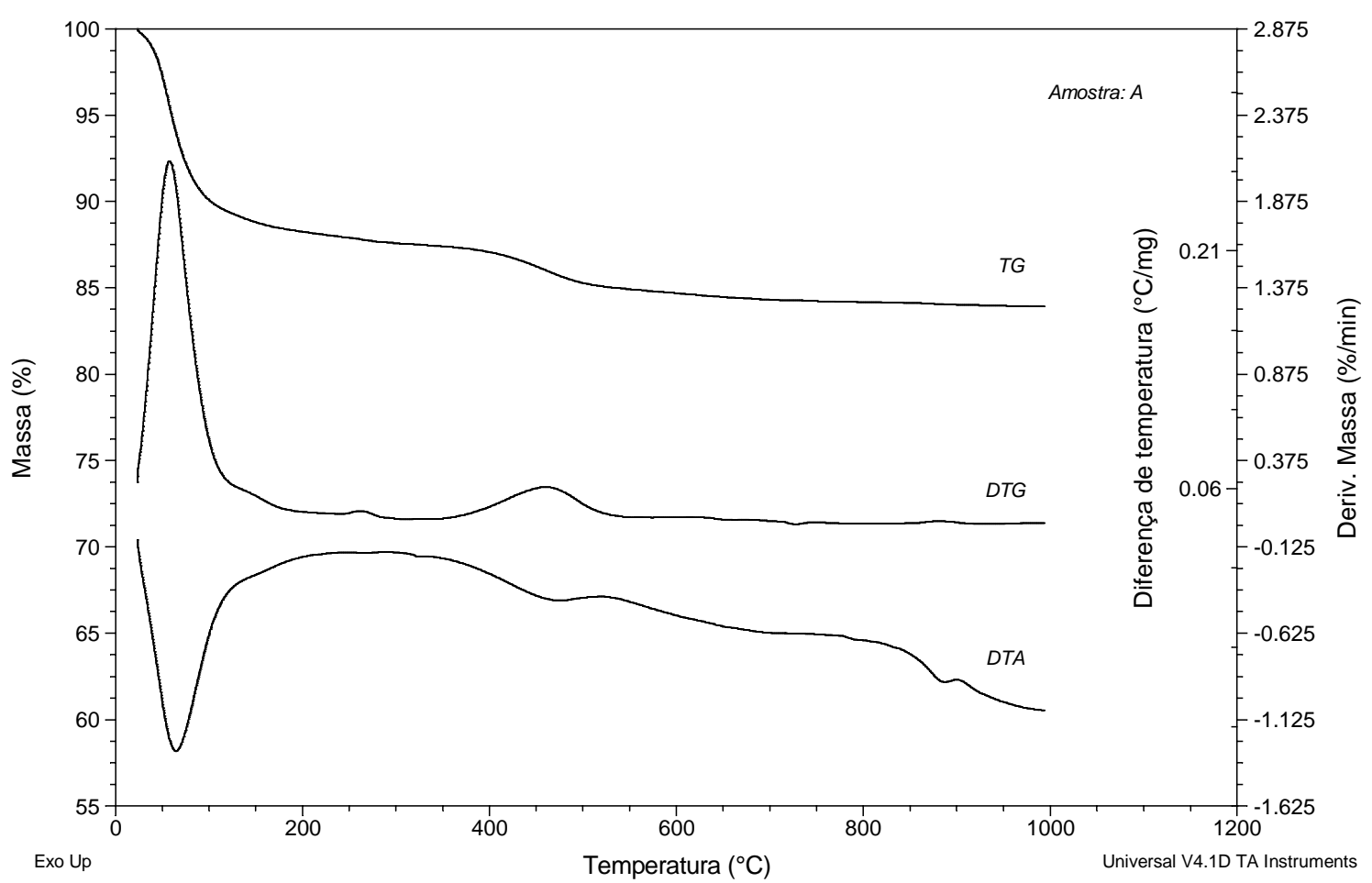

Figura 4.5.1 - Curvas TG, DTG e DTA da amostra A.

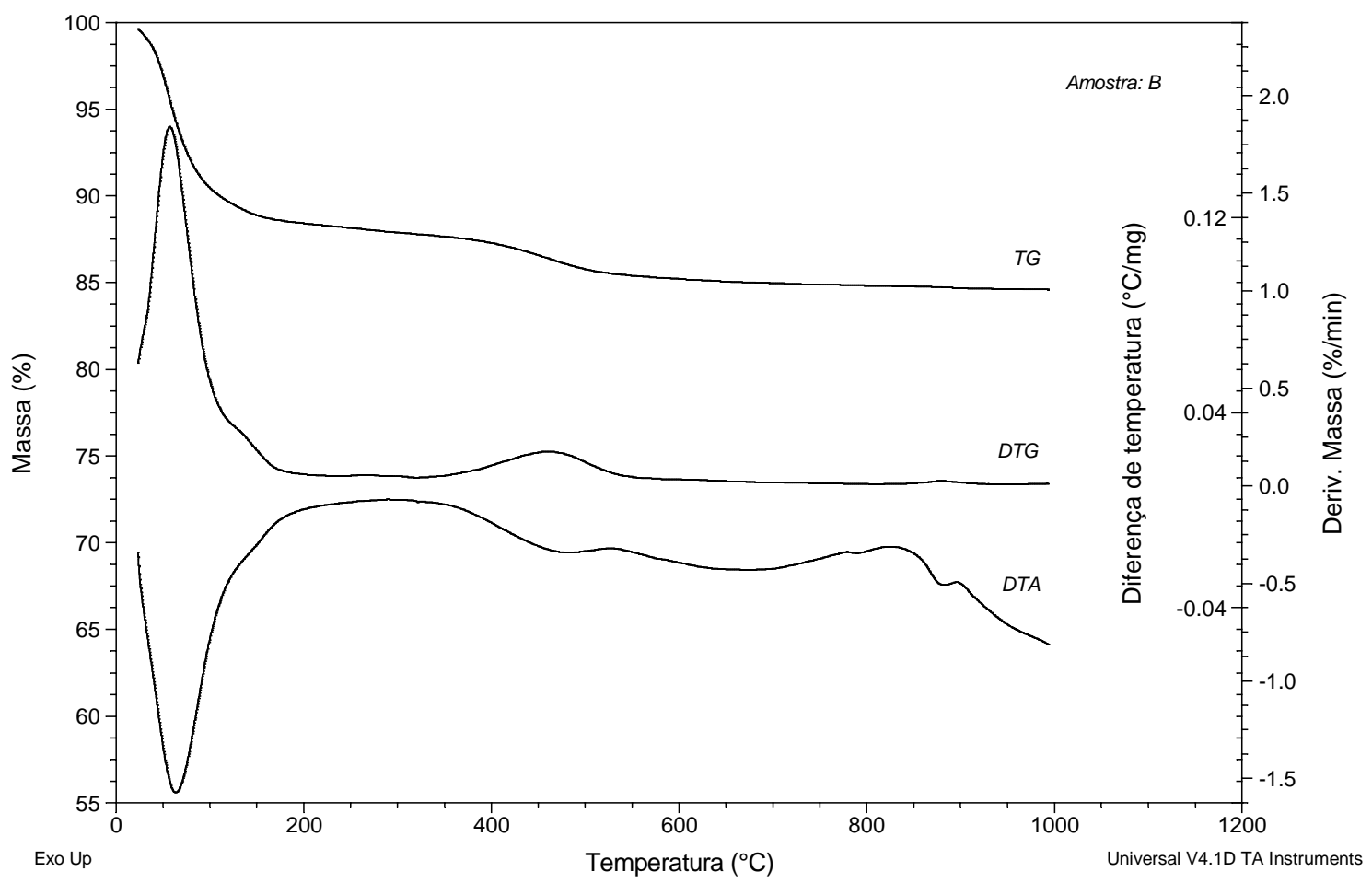

Figura 4.5.2 - Curvas TG, DTG e DTA da amostra B. 


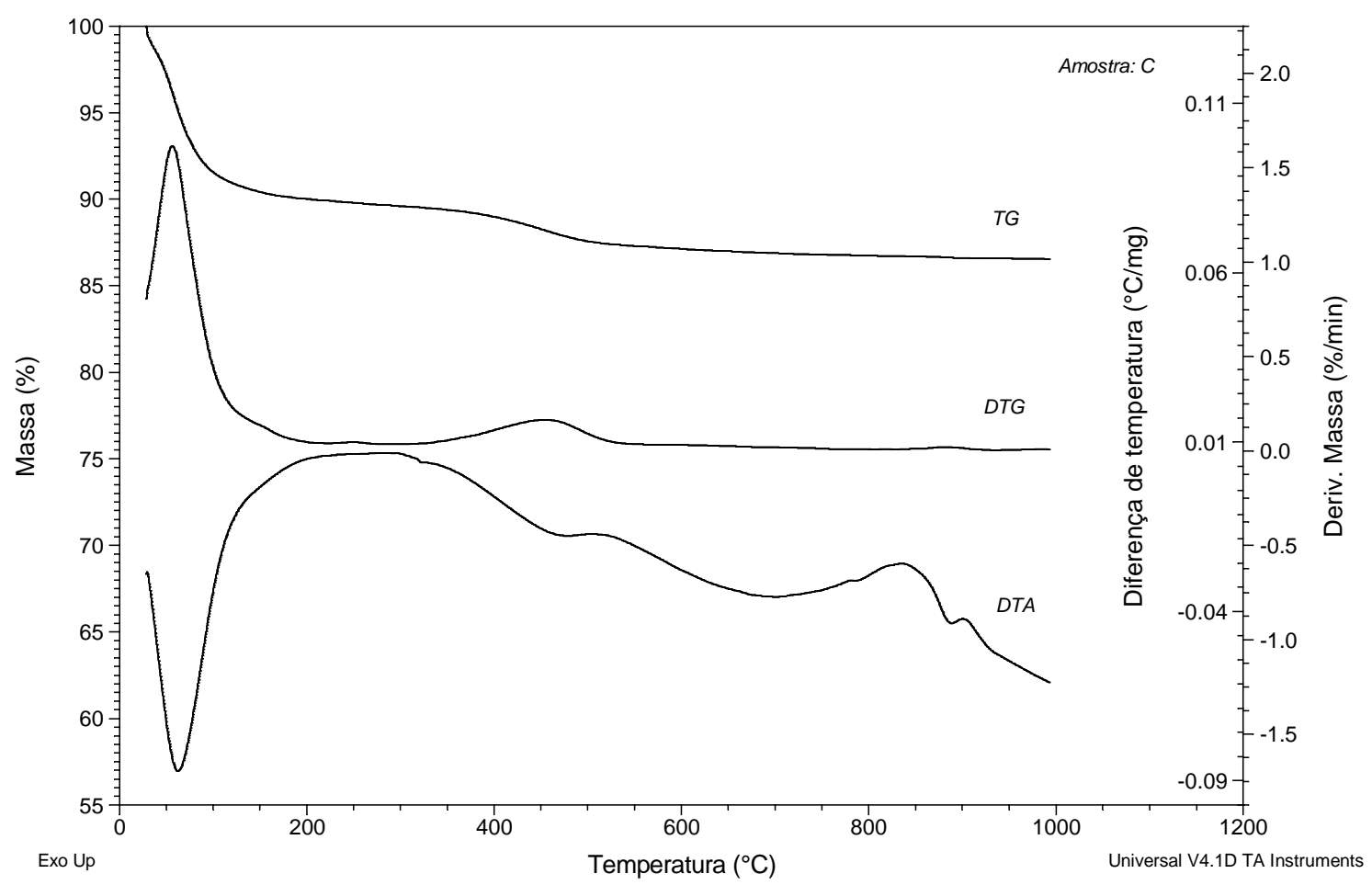

Figura 4.5.3 - Curvas TG, DTG e DTA da amostra C.

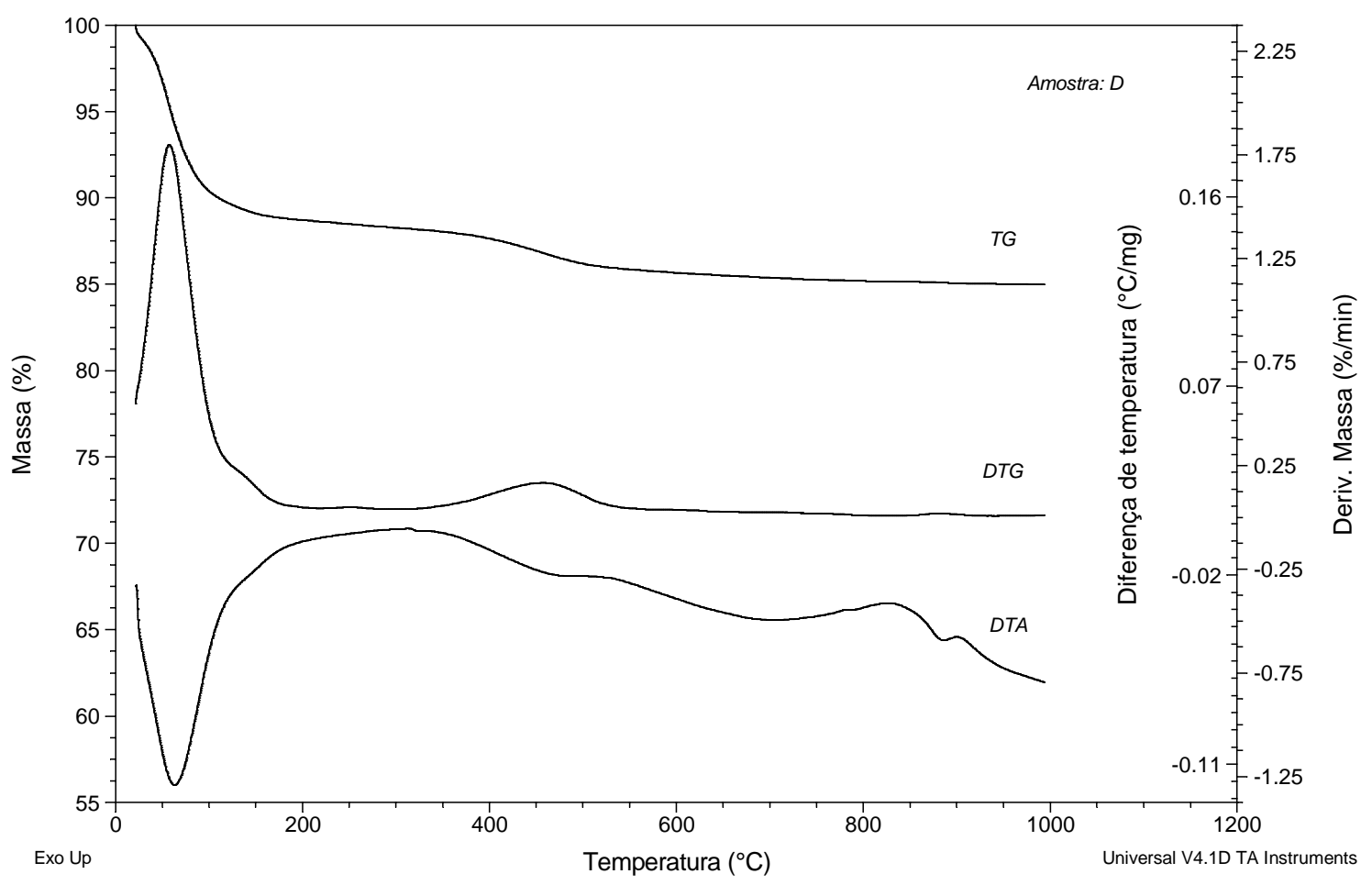

Figura 4.5.4 - Curvas TG, DTG e DTA da amostra D. 
Tabela 4.5.1 - Perdas de massa total das amostras A, B, C e D.

\begin{tabular}{c|c}
\hline Amostra & $\begin{array}{c}\text { Perda de massa total } \\
\text { (\%) }\end{array}$ \\
A & 16,1 \\
B & 15,4 \\
C & 13,5 \\
D & 15,0 \\
\hline
\end{tabular}

As curvas obtidas para as quatro amostras também são similares, o que reforça a indicação de as amostras pertencerem a uma mesma camada geológica. As curvas apresentam uma curva endotérmica de perda de umidade e de água interlamelar que vai da temperatura ambiente a aproximadamente $200^{\circ} \mathrm{C}$. Os picos endotérmicos de desidroxilação aparecem na faixa de $400^{\circ} \mathrm{C}$ a $600^{\circ} \mathrm{C}$ e os picos endo-exotérmicos, característicos dos argilominerais esmectíticos (destruição do reticulado cristalino e formação de quartzo beta a partir da estrutura amorfa criada anteriormente) na faixa de $800^{\circ}$ a $900^{\circ} \mathrm{C}$ [SOUZA SANTOS, 1975].

\subsection{Microscopia Eletrônica de Varredura (MEV)}

As micrografias apresentadas na Figuras 4.6.1, 4.6.2, 4.6.3 e 4.6.4 são referentes às amostras naturais $A, B, C$ e $D$, respectivamente.
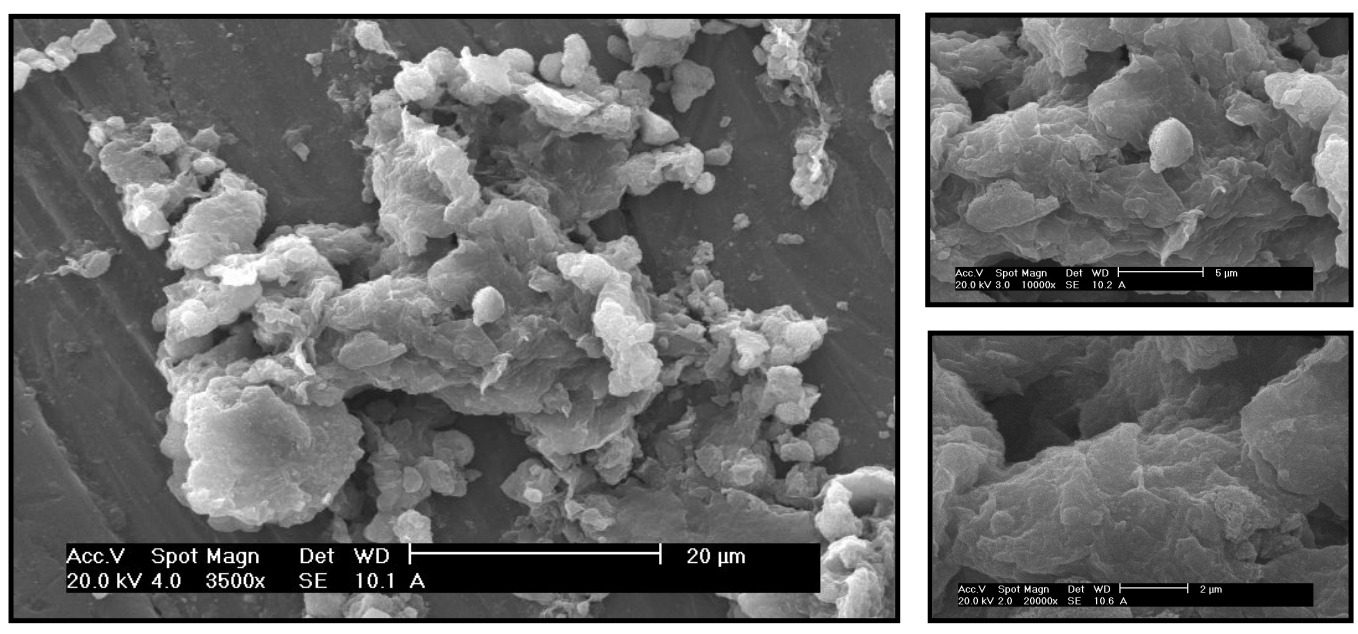

Figura 4.6.1 - Micrografias da amostra A. 

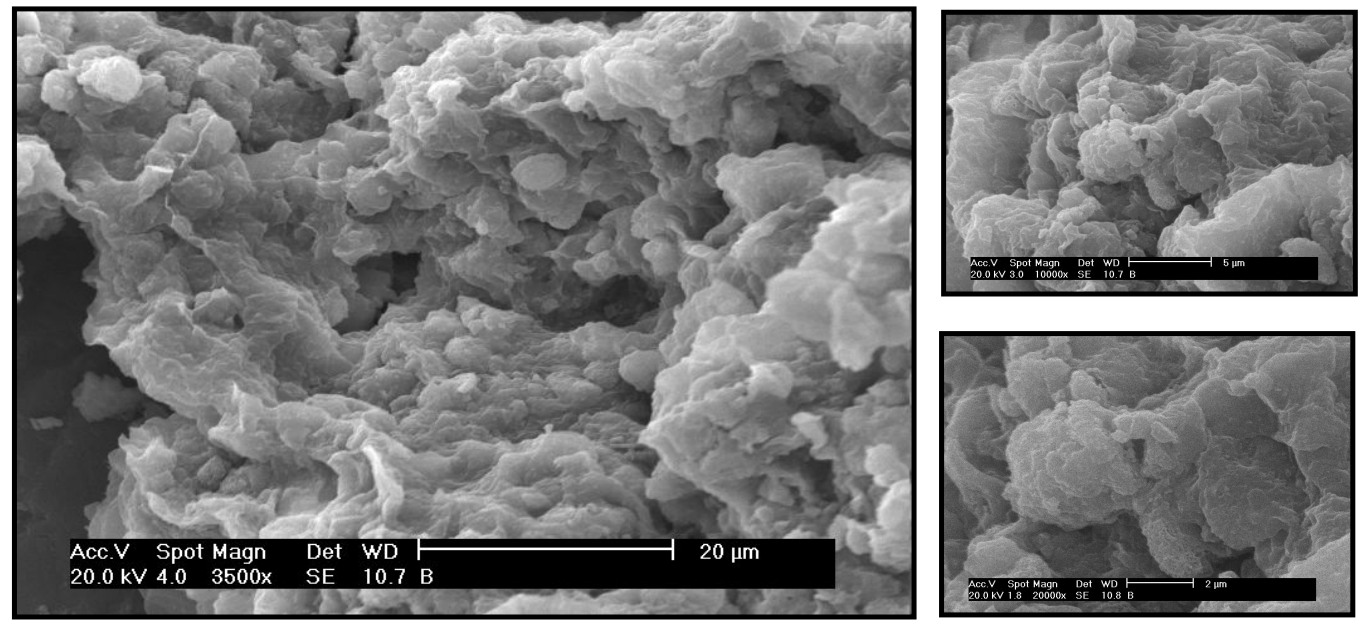

Figura 4.6.2 - Micrografias da amostra B.
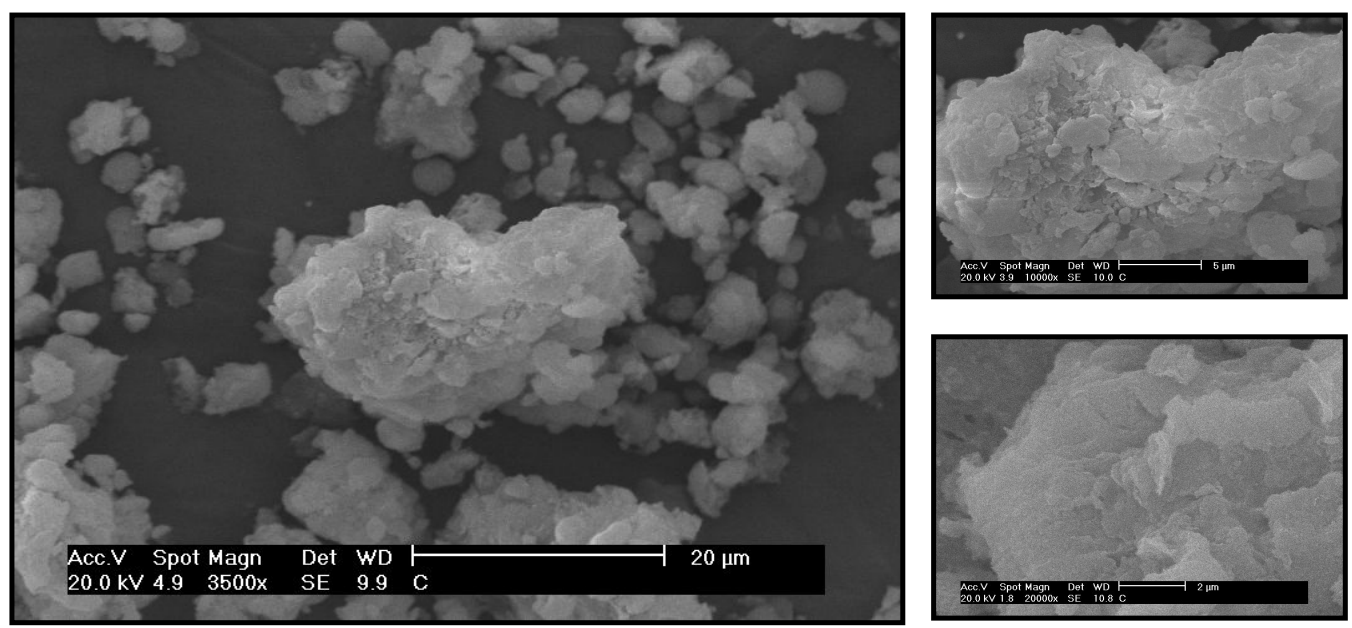

Figura 4.6.3 - Micrografias da amostra C.
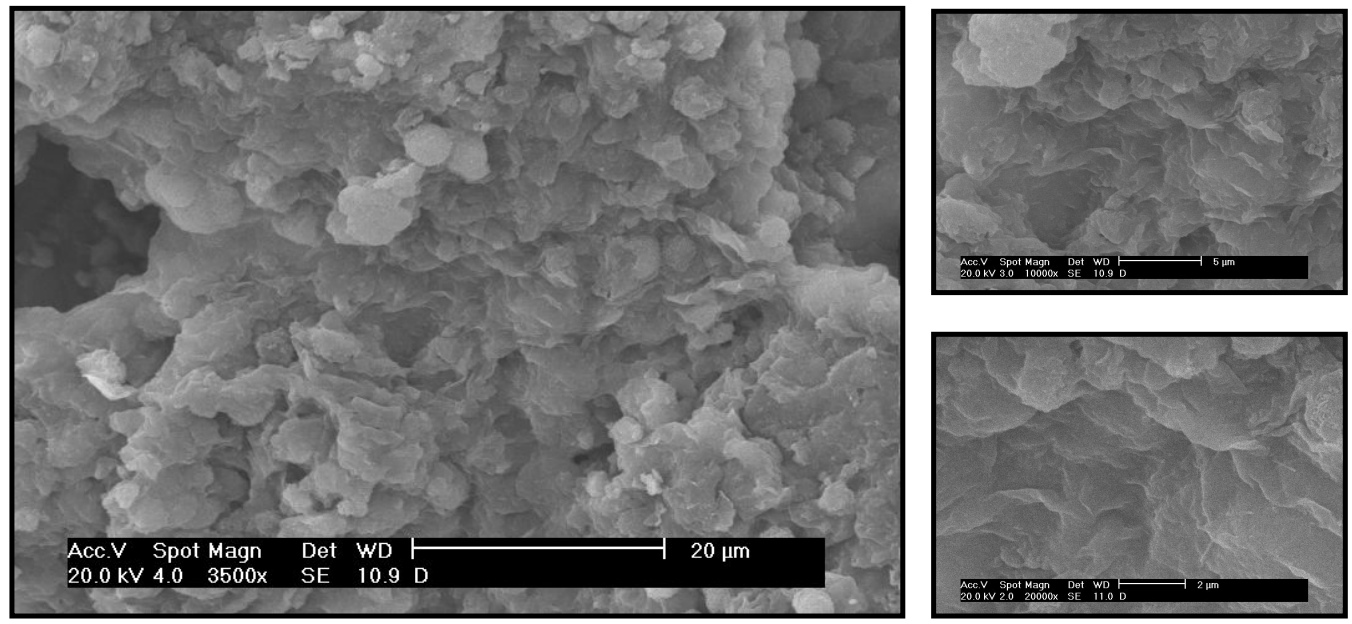

Figura 4.6.4 - Micrografias da amostra D. 
Nas micrografias das amostras naturais $A, B, C$ e D, é possível observar que as partículas lamelares se encontram empilhadas e aglomeradas, formando aglomerados de morfologia irregular e com dimensões variáveis e geralmente maiores que 20 micrômetros, concordando com o comportamento apresentado por Gomes [1988] para argilas deste grupo.

Segundo Neaman; Pelletier; Villieras [2003], uma argila lamelar seca pode ser descrita por três unidades estruturais e pelo arranjo dessas unidades no espaço. A primeira unidade é a camada (partícula cristalina elementar), e no caso das esmectitas, espessura aproximada de 1,0nm e diâmetro entre 1 e $2 \mu \mathrm{m}$. a segunda unidade é o tactóide que é constituído pelo empilhamento das camadas elementares. A terceira unidade é o aglomerado, constituído por vários tactóides.

A amostra $A$ apresentou nas micrografias aglomerados variando em diâmetro, desde aproximadamente $0,7 \mu \mathrm{m}$ até aproximadamente $40 \mu \mathrm{m}$.

A amostra $B$ apresentou nas micrografias aglomerado com diâmetro maior a $68 \mu \mathrm{m}$ formado por lamelas com diâmetros variando aproximadamente entre $0,7 \mu \mathrm{m}$ a $2 \mu \mathrm{m}$.

A amostra $\mathrm{C}$ apresentou nas micrografias aglomerados variando em diâmetro desde aproximadamente $0,7 \mu \mathrm{m}$ até aproximadamente $30 \mu \mathrm{m}$.

A amostra $D$ apresentou nas micrografias aglomerado com diâmetro de maior a $68 \mu \mathrm{m}$ formado por lamelas com diâmetros variando aproximadamente entre $0,7 \mu \mathrm{m}$ a $2 \mu \mathrm{m}$.

As partículas menores, de todas as amostras, foram visualizadas em monitor de computador (17 polegadas), utilizando-se o aumento de 500x fornecido pelo Word ${ }^{\circledR}$.

De forma geral, a partir das observações diretas das micrografias apresentadas nas Figuras 4.6.1 a 4.6.4, verifica-se que o material é constituído de aglomerados de perfil irregular de contorno bem definidos, com diâmetro variando de $0,7 \mu \mathrm{m}$ até aproximadamente $40 \mu \mathrm{m}$. 


\section{CAPÍTULO 5}

\section{Resultados e discussão Ativação Ácida}

Neste capítulo, serão apresentados os resultados obtidos no estudo da ativação ácida. 


\subsection{Difração de Raios-X (DRX)}

As Figuras 5.1.1, 5.1.2 e 5.1.3 apresentam os difratogramas das amostras A, $\mathrm{B}, \mathrm{C}$ e D ativadas com tempo de reação de 1 hora.

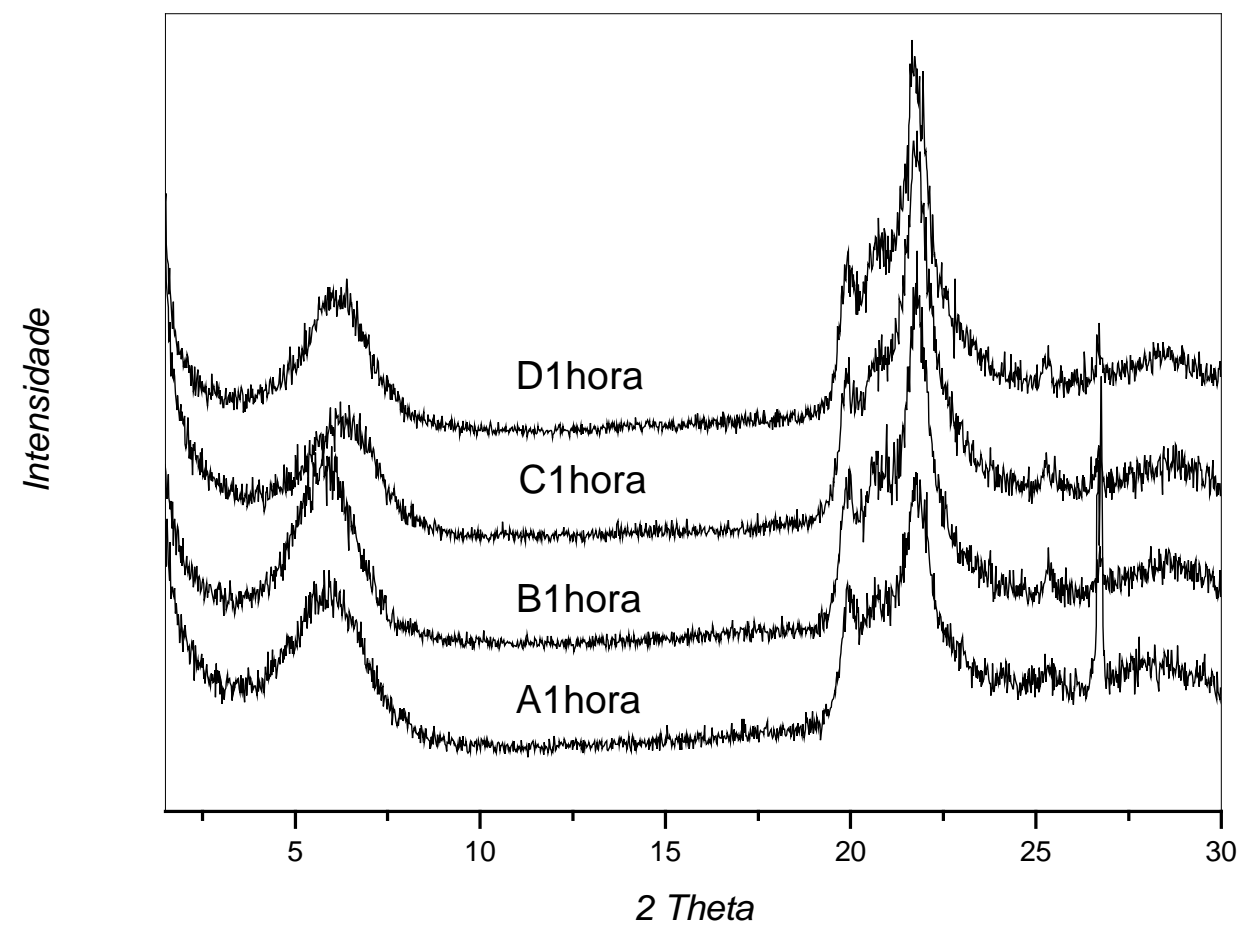

Figura 5.1.1 - Difratogramas das amostras A, B, C e D ativadas com ácido clorídrico e tempo de reação de 1 hora. 


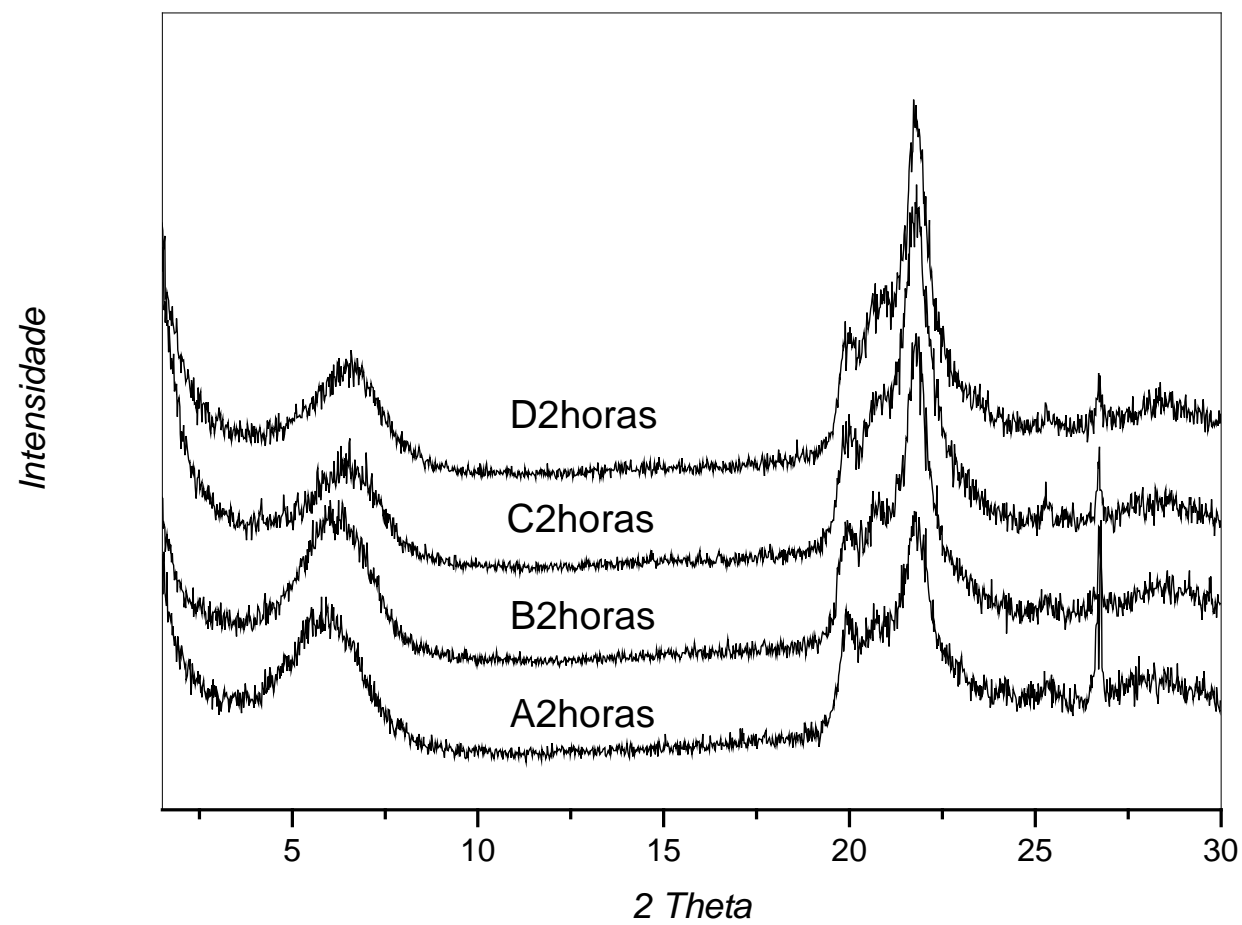

Figura 5.1.2 - Difratogramas das amostras A, B, C e D ativadas com ácido clorídrico e tempo de reação de 2 horas.

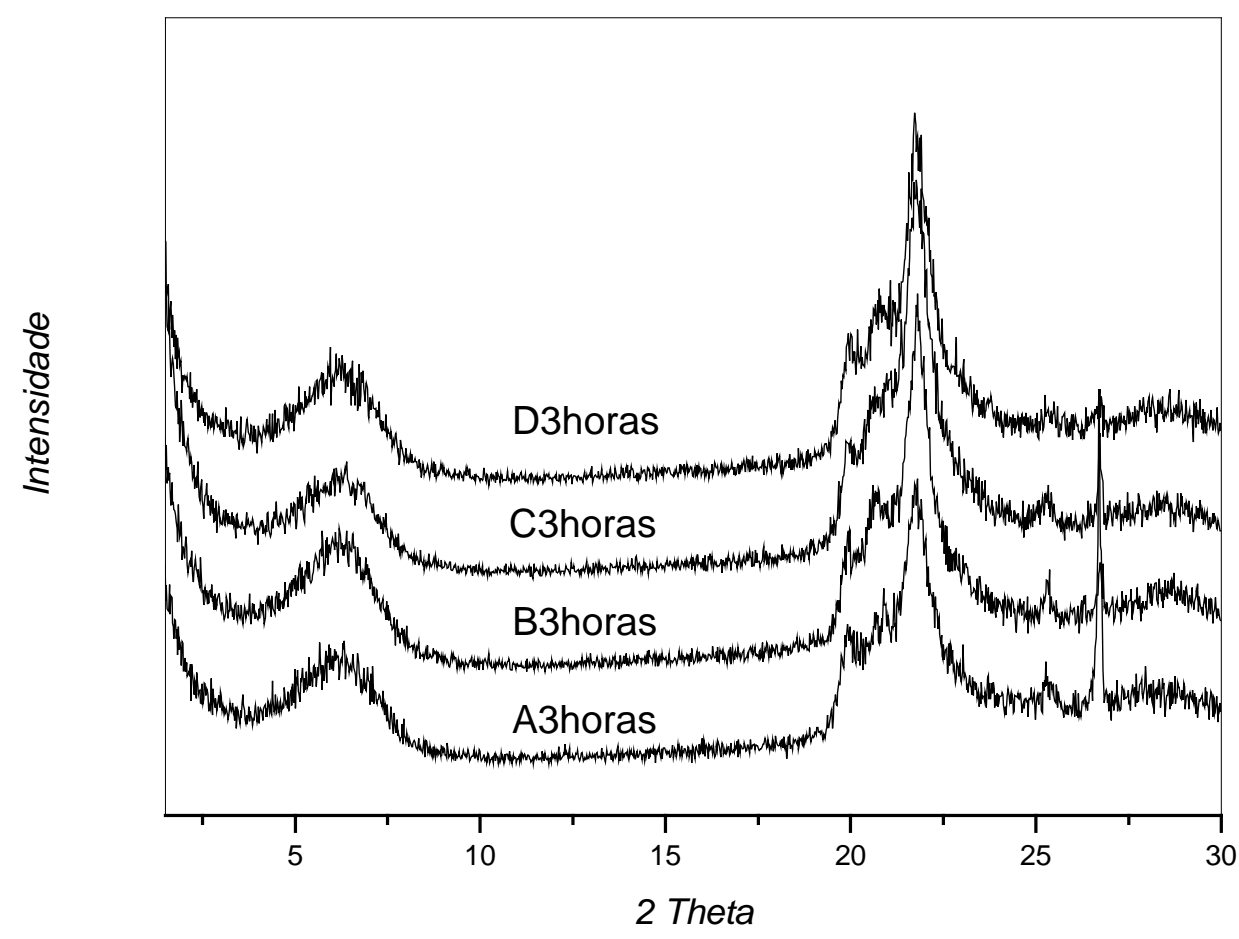

Figura 5.1.3 - Difratogramas das amostras A, B, C e D ativadas com ácido clorídrico e tempo de reação de 3 horas. 
Os difratogramas apresentados nas Figuras acima evidenciam a intensidade mais alta dos picos característicos dessas argilas, que apresentam predominantemente a montmorilonita como argilomineral.

A manutenção desses picos, porém com uma pequena diminuição na intensidade em relação à amostra sem tratamento, nas amostras atacadas por 1, $2 \mathrm{e}$ 3 horas, indica que o tratamento não provocou danos substanciais nas camadas octaédricas dos argilominerais. A Tabela 5.1.1 apresenta os valores das distâncias interlamelares das amostras estudadas.

Tabela 5.1.1 - Distâncias interlamelares das amostras A, B, C e D ativadas com tempos de reação de 1, 2 e 3 horas.

\begin{tabular}{c|c}
\hline Amostra & $\begin{array}{c}\text { Distância interlamelar } \mathbf{n m} \\
\left(\mathbf{d}_{\text {o01 }}\right)\end{array}$ \\
\hline A1hora & 1,441 \\
B1hora & 1,413 \\
C1hora & 1,489 \\
D1hora & 1,474 \\
& \\
A2horas & 1,401 \\
B2horas & 1,369 \\
C2horas & 1,399 \\
A2horas & 1,474 \\
& \\
A3horas & 1,413 \\
B3horas & 1,426 \\
C3horas & 1,426 \\
D3horas & 1,426 \\
\hline
\end{tabular}

Um dos fatores que muitos autores citam [DOMBROWSKY; HENDERSON, 1997, GRIM, 1968] é que, quando se aumenta a intensidade do tratamento ácido a intensidade do pico característico diminui, fato provocado pela alteração da estrutura cristalina e seguido pela dissolução das folhas octaédricas e tetraédricas [VALENZUELA DÍAZ; SOUZA SANTOS, 2001, TKAC; KOMANDEL, 1994, VALENZUELA DÍAZ; SOUZA SANTOS, 1991].

Para verificar esta ocorrência, realizou-se com todas as amostras a ativação pelo período de 1, 2, 3, 4, 5, 6 e 7 dias e os resultados foram acompanhados pela Difração de Raios-X e Espectroscopia na Região do Infravermelho, apresentado nas Figuras 5.1 .4 a 5.1 .7 e 5.2.2. 


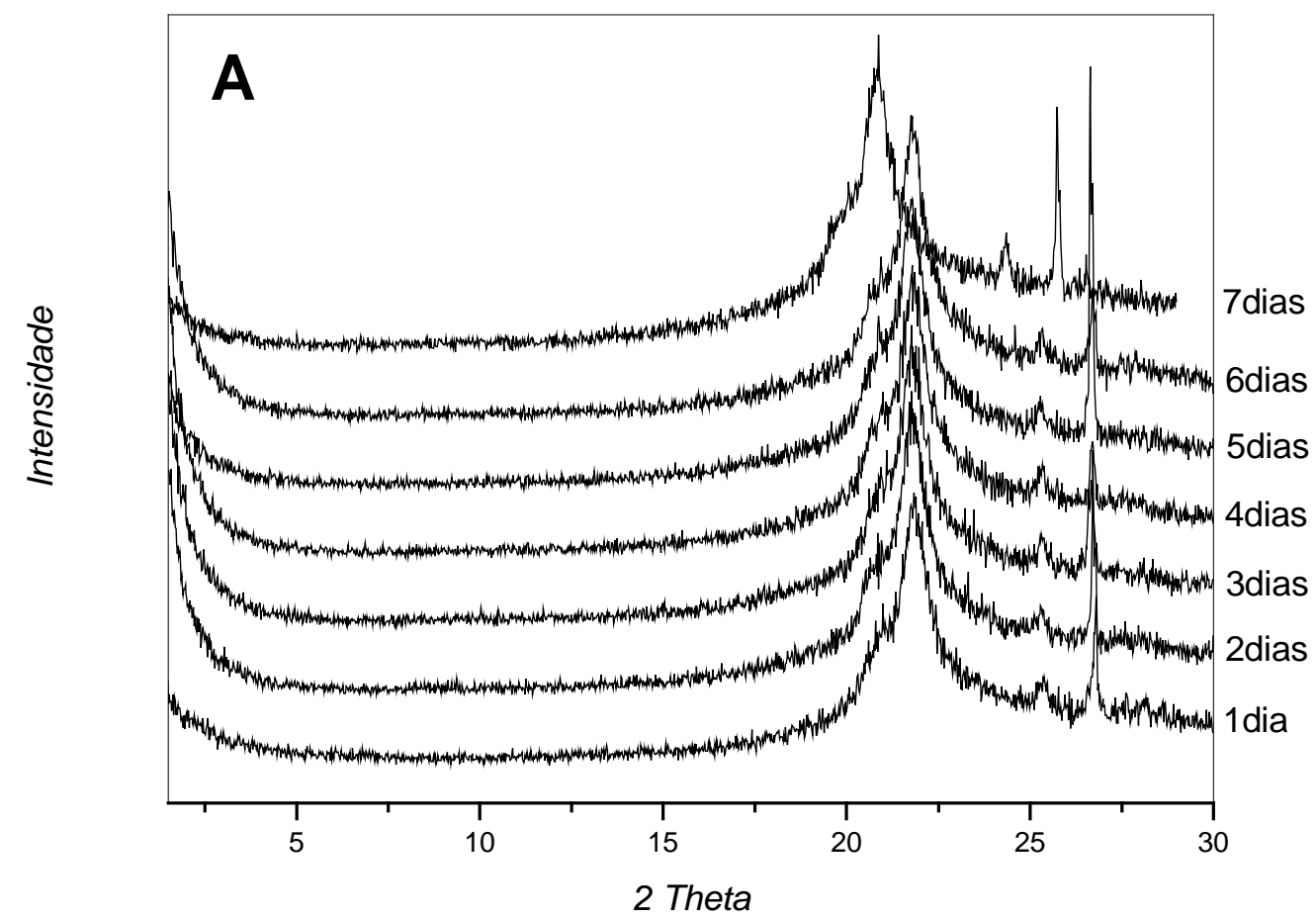

Figura 5.1.4 - Difratogramas da amostra A ativada com ácido clorídrico e tempo de reação de 1, 2, 3, 4, 5, 6 e 7 dias.

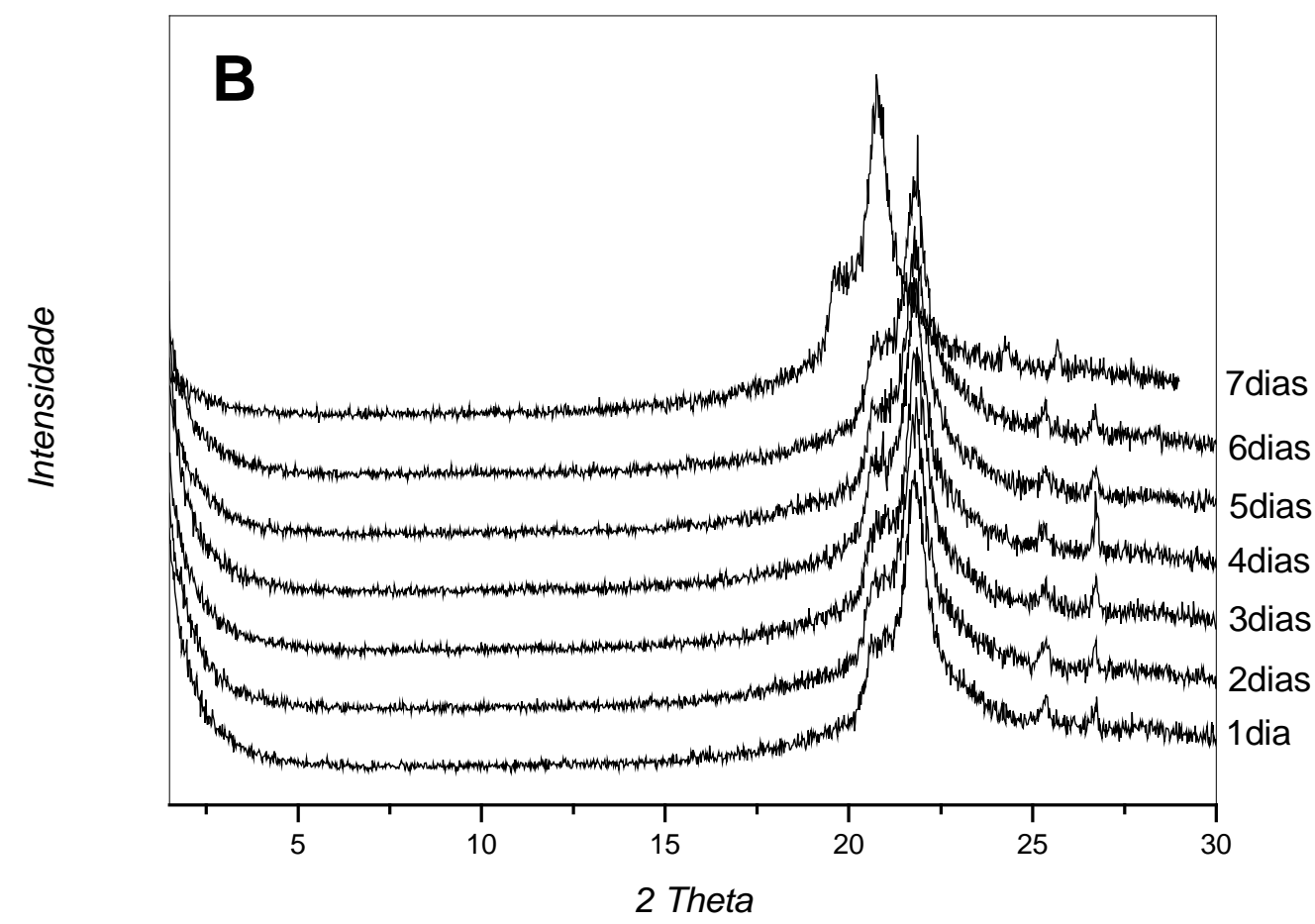

Figura 5.1.5 - Difratogramas da amostra B ativada com ácido clorídrico e tempo de reação de 1, 2, 3, 4, 5, 6 e 7 dias. 


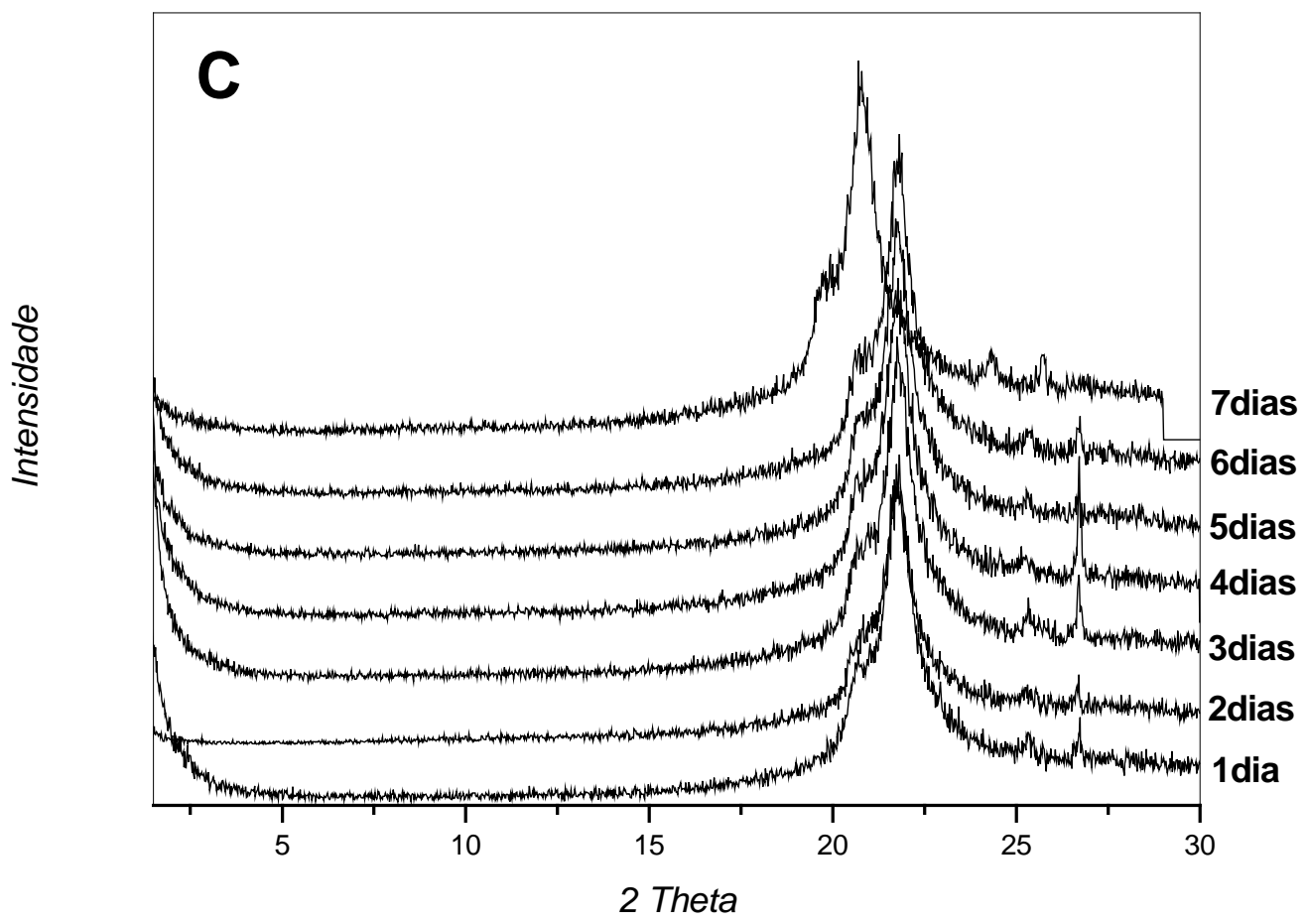

Figura 5.1.6 - Difratogramas da amostra $C$ ativada com ácido clorídrico e tempo de reação de 1, 2, 3, 4, 5, 6 e 7 dias.

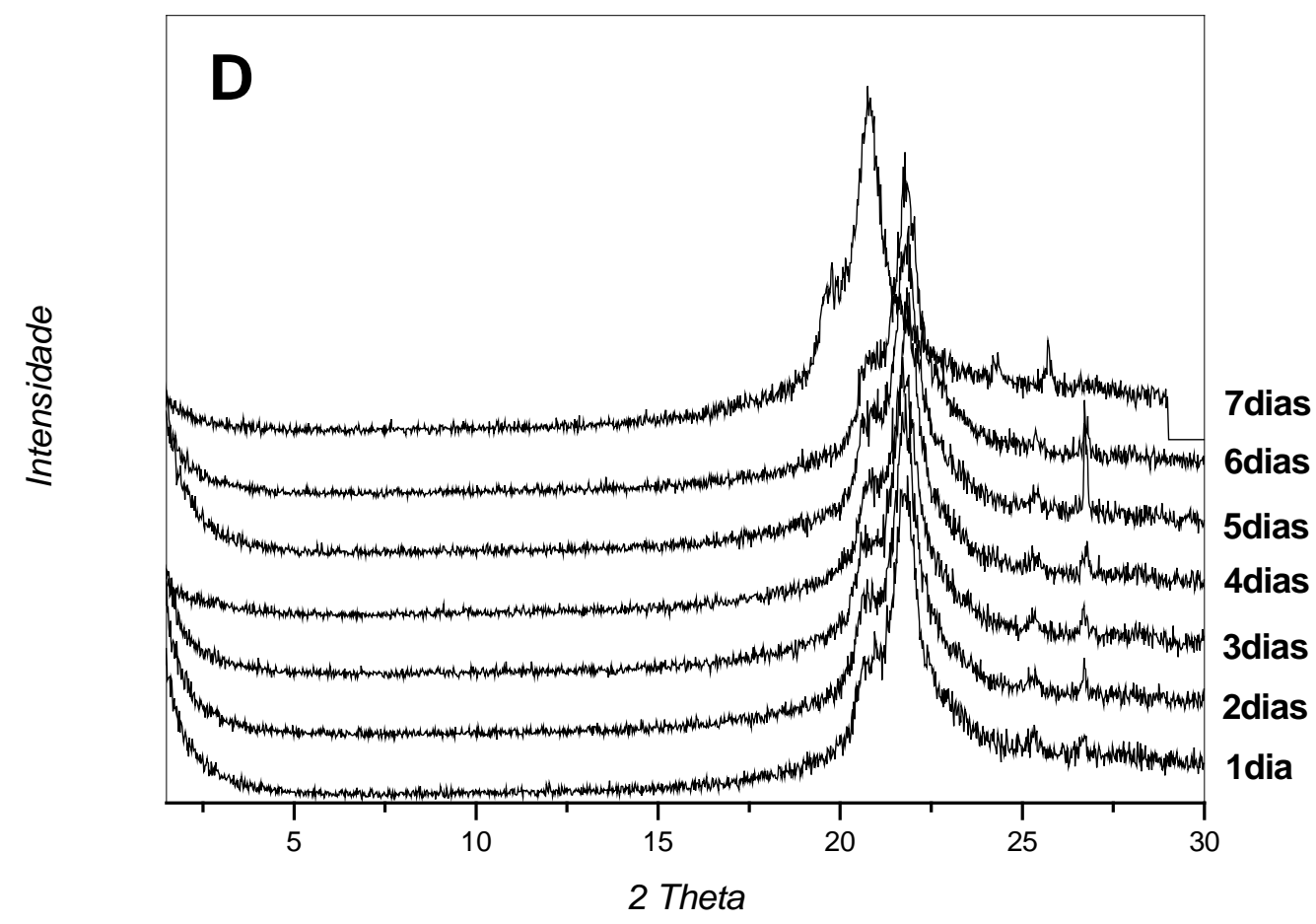

Figura 5.1.7 - Difratogramas da amostra $D$ ativada com ácido clorídrico e tempo de reação de 1, 2, 3, 4, 5, 6 e 7 dias. 
Observa-se que com o aumento do tempo de reação, em todas as amostras, não se apresenta o pico característico deste tipo de argila, ou seja, o tratamento ácido nestas condições promove destruição acentuada das camadas do argilomineral esmectítico, estando de acordo com Dombrowsky; Henderson [1997] e Grim [1968].

Rodrigues; Pereira; Valenzuela Díaz [2006] verificaram que o tempo de reação de 7 dias, na ativação ácida de uma argila esmectítica, utilizando ácido clorídrico, também causou danos acentuados a estrutura do argilomineral esmectítico.

\subsection{Espectroscopia na Região do Infravermelho (FTIR)}

As Figura 5.2.1, 5.2.2 e 5.2.3 apresentam os espectros na região do infravermelho das amostras ativas com tempo de reação de 1, 2 e 3 horas.

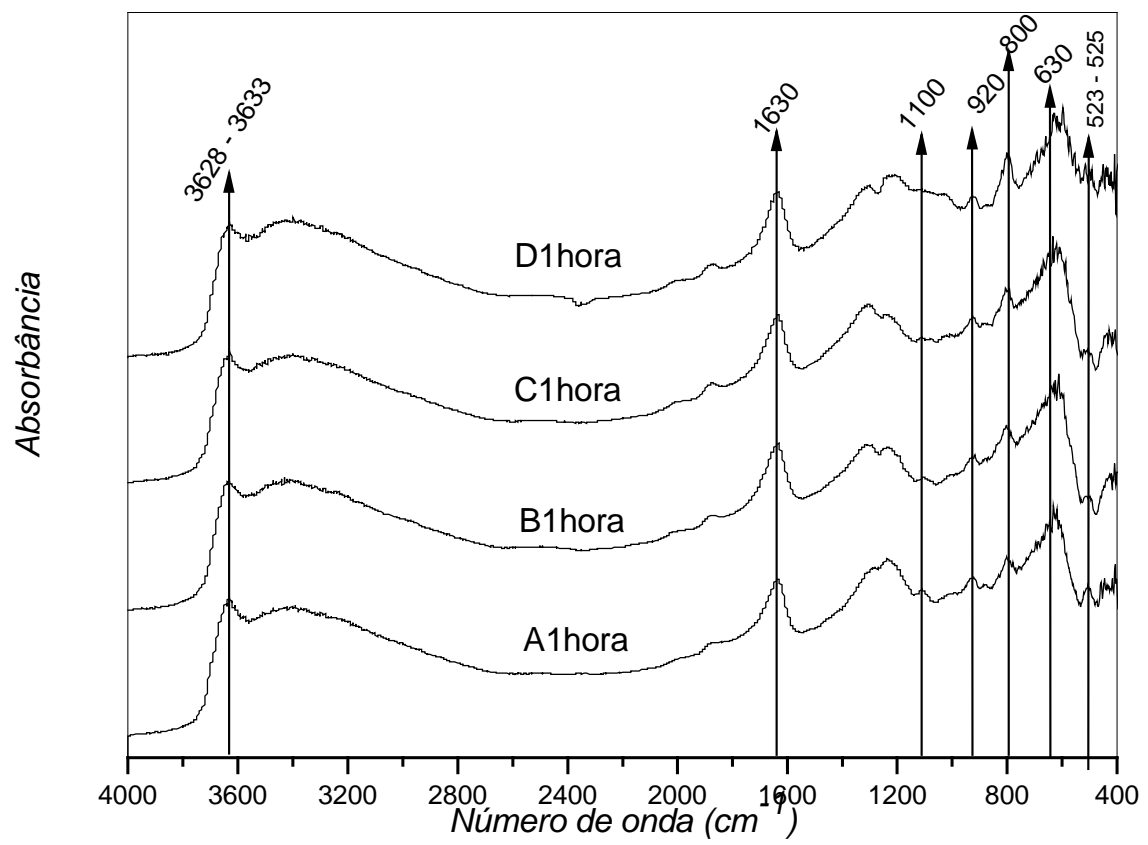

Figura 5.2.1 - Espectroscopia na região do infravermelho das amostras A, B, C e D ativadas com tempo de reação de 1 hora. 


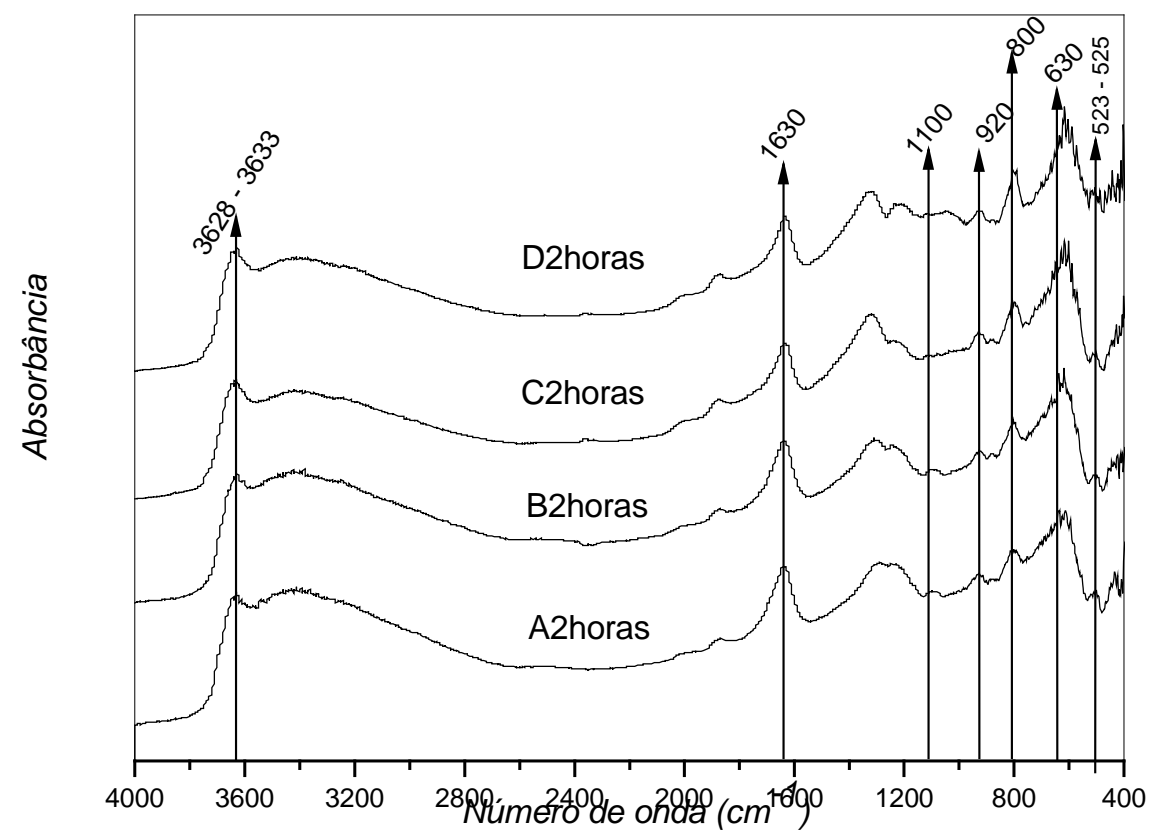

Figura 5.2.2 - Espectroscopia na região do infravermelho das amostras A, B, C e D ativadas com tempo de reação de 2 horas.

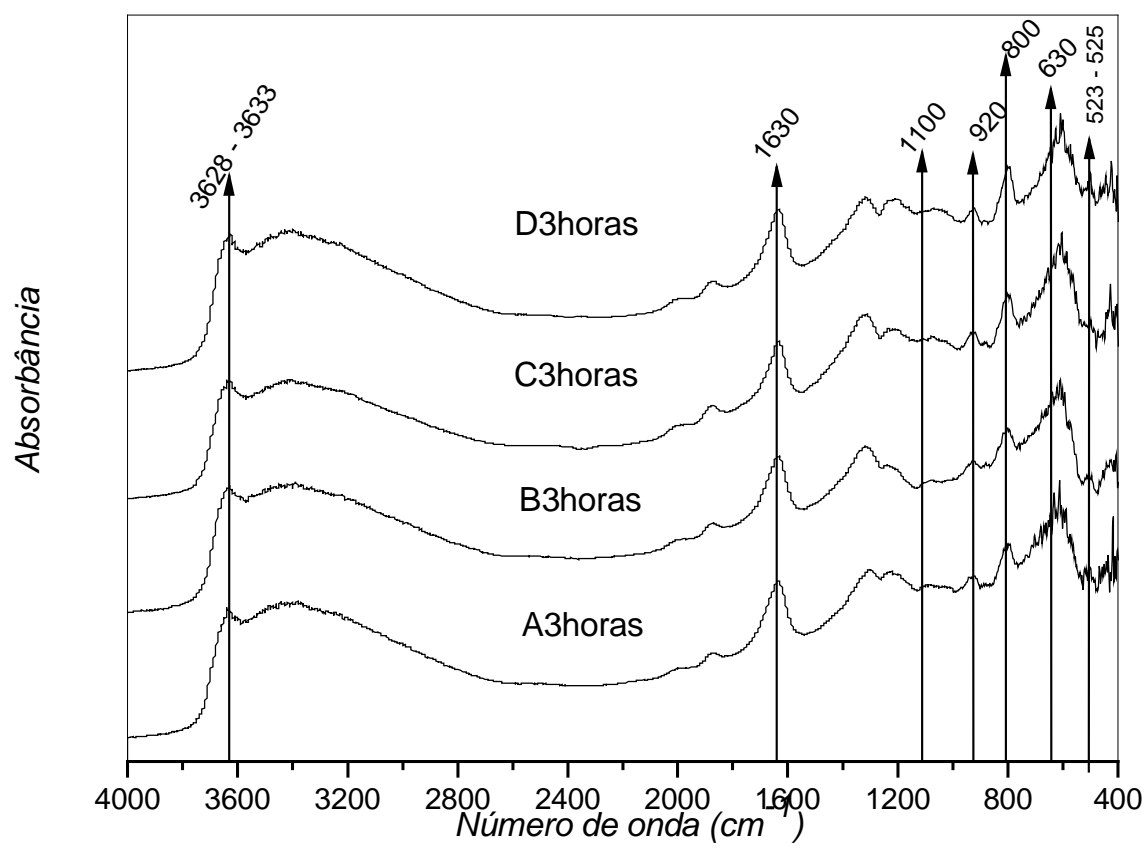

Figura 5.2.3 - Espectroscopia na região do infravermelho das amostras A, B, C e D ativadas com tempo de reação de 3 horas. 
Como comentado no item 4.4 (Capítulo 4: Resultados e discussão - Argilas naturais), verifica-se nas amostras ativadas com tempo de reação de 1, 2 e 3 horas bandas compreendidas na faixa entre $3633-3628 \mathrm{~cm}^{-1}$ e $1630 \mathrm{~cm}^{-1}$ (característicos do grupo O-H); $1100 \mathrm{~cm}^{-1}$ e $523-525 \mathrm{~cm}^{-1}$ (característicos da ligação Si-O); $630 \mathrm{~cm}^{-1}$ (característico da ligação Al-O) e $920 \mathrm{~cm}^{-1}, 800 \mathrm{~cm}^{-1}$ (característicos das camadas octaédricas). Estando em conformidade com os difratogramas de raios- $\mathrm{X}$, indicando que o tratamento com estes tempos de reação não provocam danos à estrutura do argilomineral.

As Figuras 5.2.4 a 5.2.10 apresentam os espectros na região do infravermelho para as amostras atacadas com tempo de reação de 1, 2, 3, 4, 5, 6 e 7 dias.

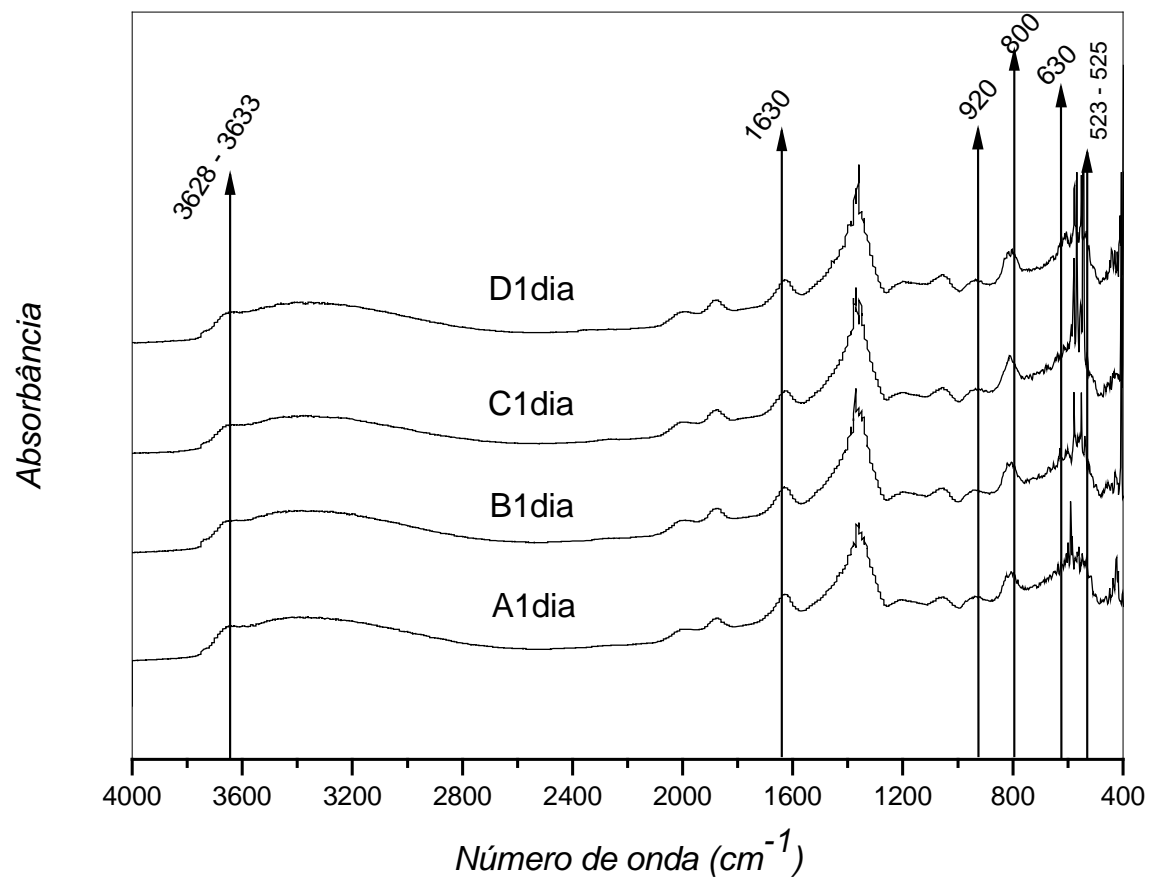

Figura 5.2.4 - Espectroscopia na região do infravermelho das amostras A, B, C e D ativadas com tempo de reação de 1 dia. 


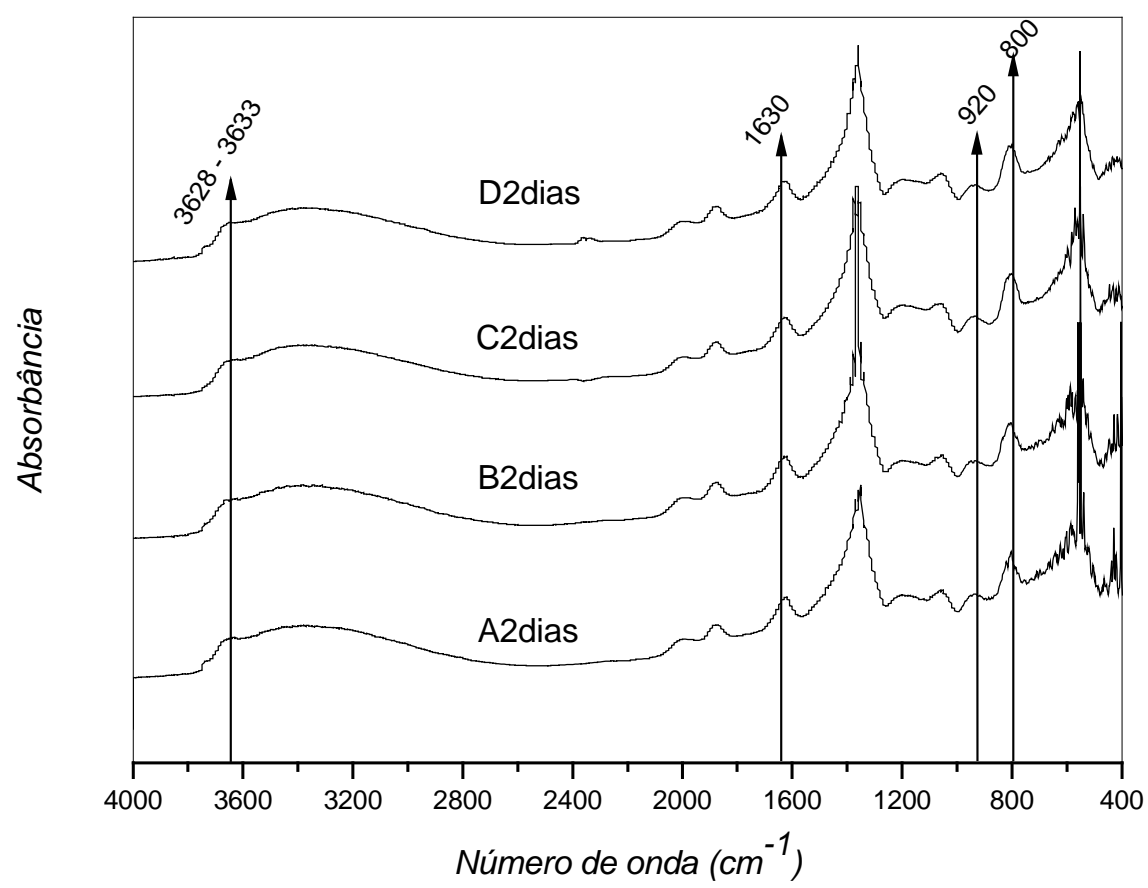

Figura 5.2.5 - Espectroscopia na região do infravermelho das amostras A, B, C e D ativadas com tempo de reação de 2 dias.

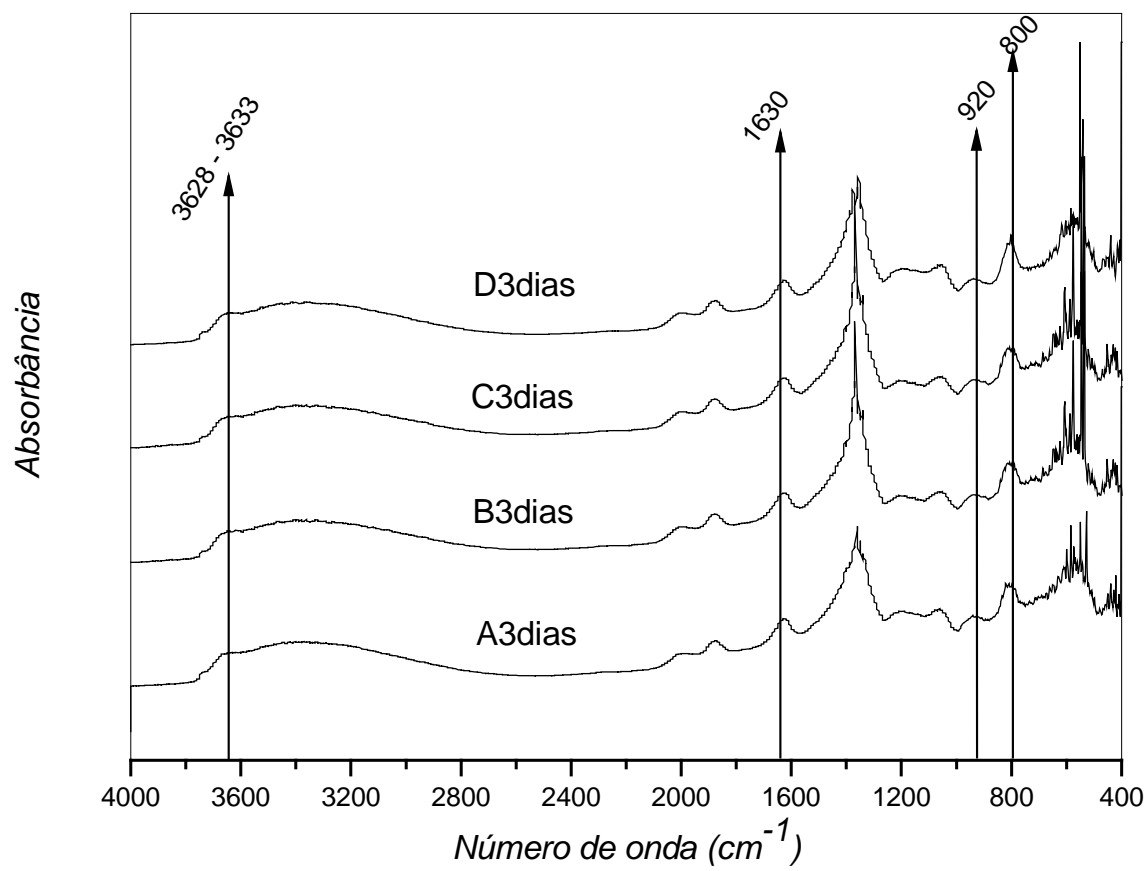

Figura 5.2.6 - Espectroscopia na região do infravermelho das amostras A, B, C e D ativadas com tempo de reação de 3 dias. 


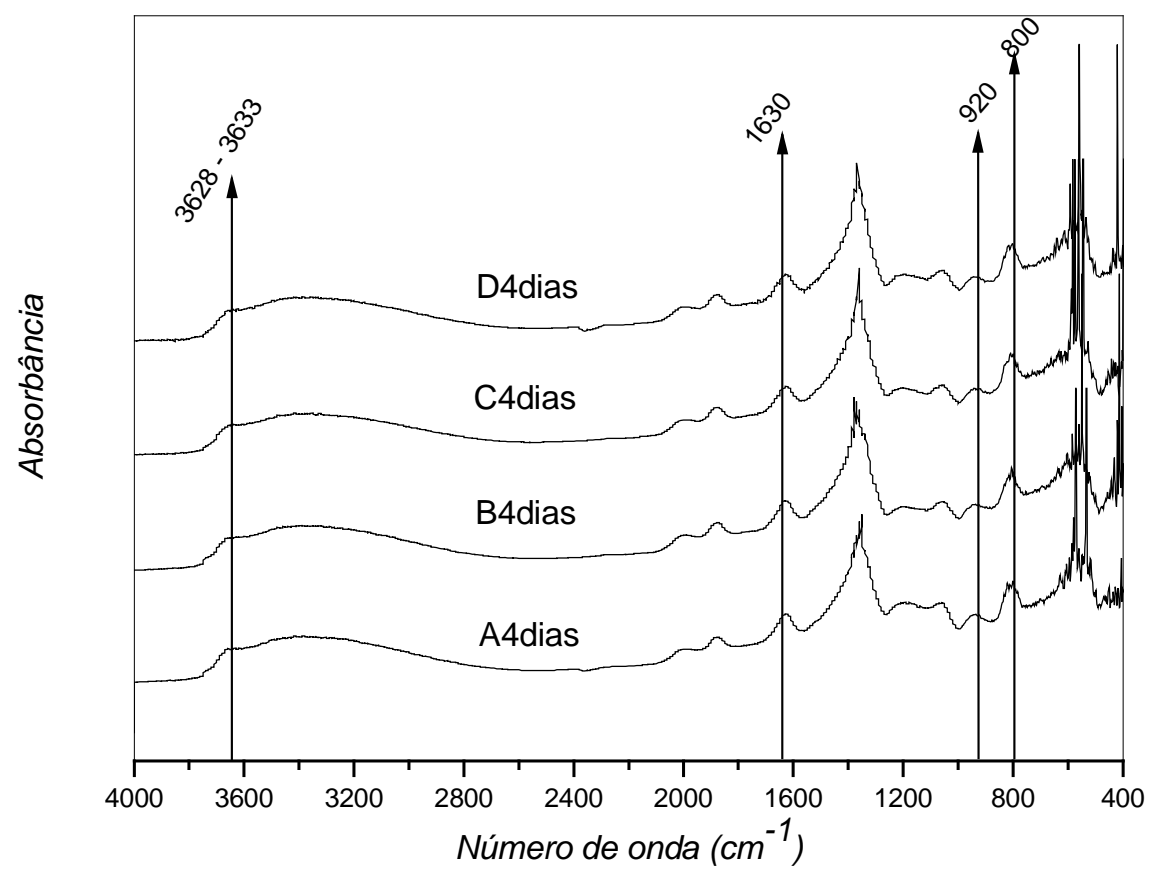

Figura 5.2.7 - Espectroscopia na região do infravermelho das amostras A, B, C e D ativadas com tempo de reação de 4 dias.

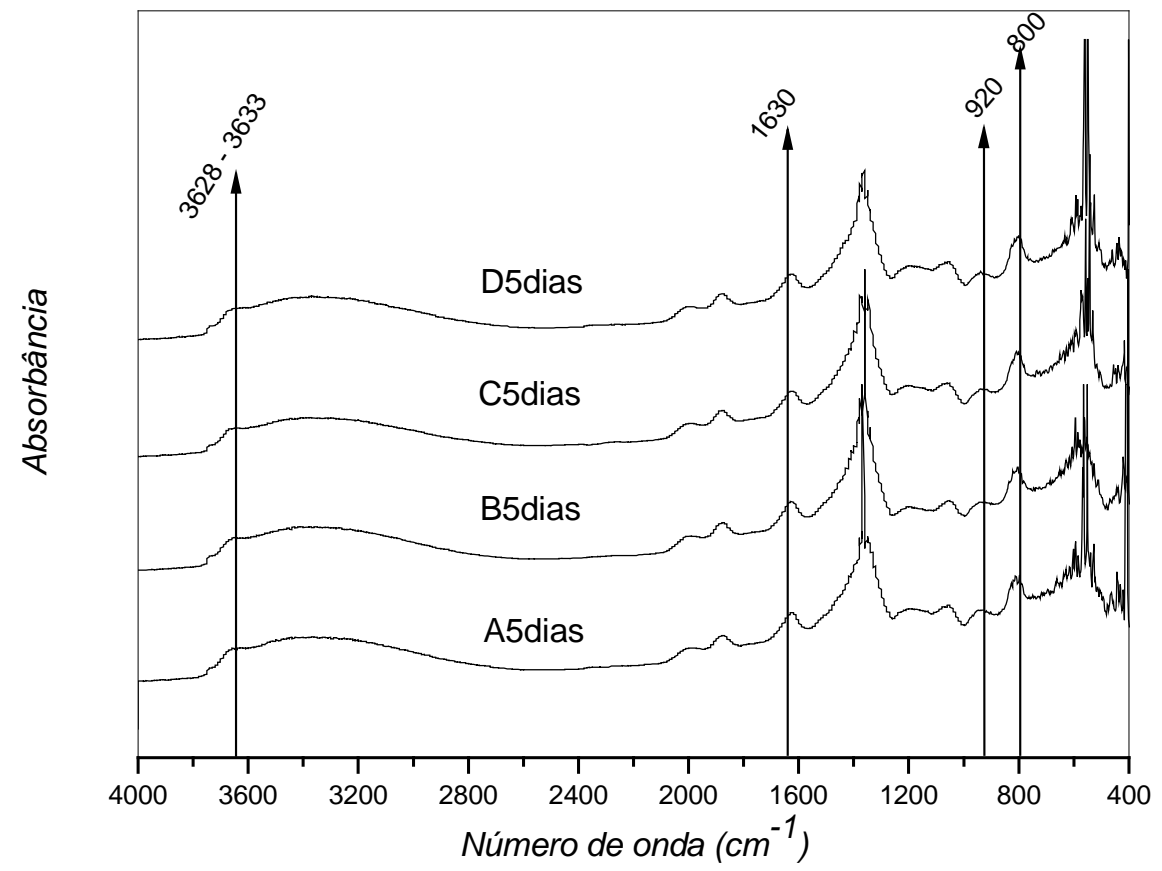

Figura 5.2.8 - Espectroscopia na região do infravermelho das amostras A, B, C e D ativadas com tempo de reação de 5 dias. 


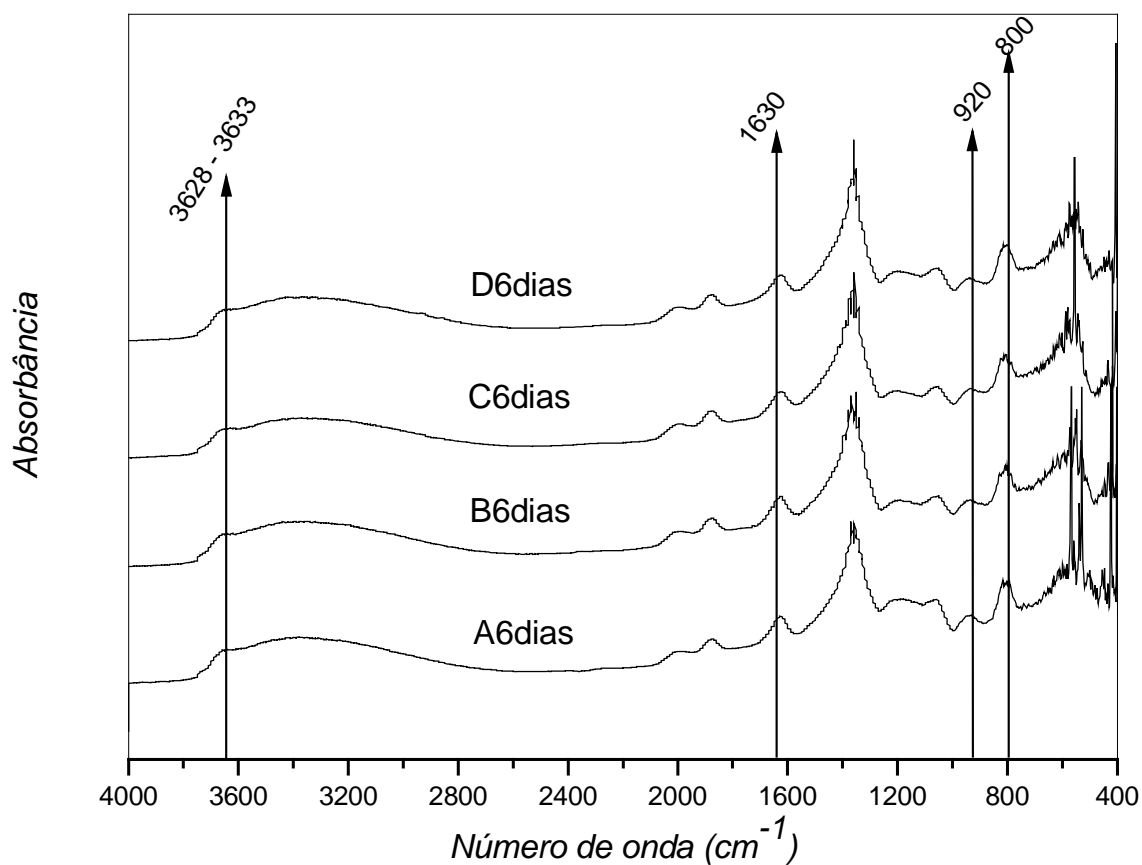

Figura 5.2.9 - Espectroscopia na região do infravermelho das amostras A, B, C e D ativadas com tempo de reação de 6 dias.

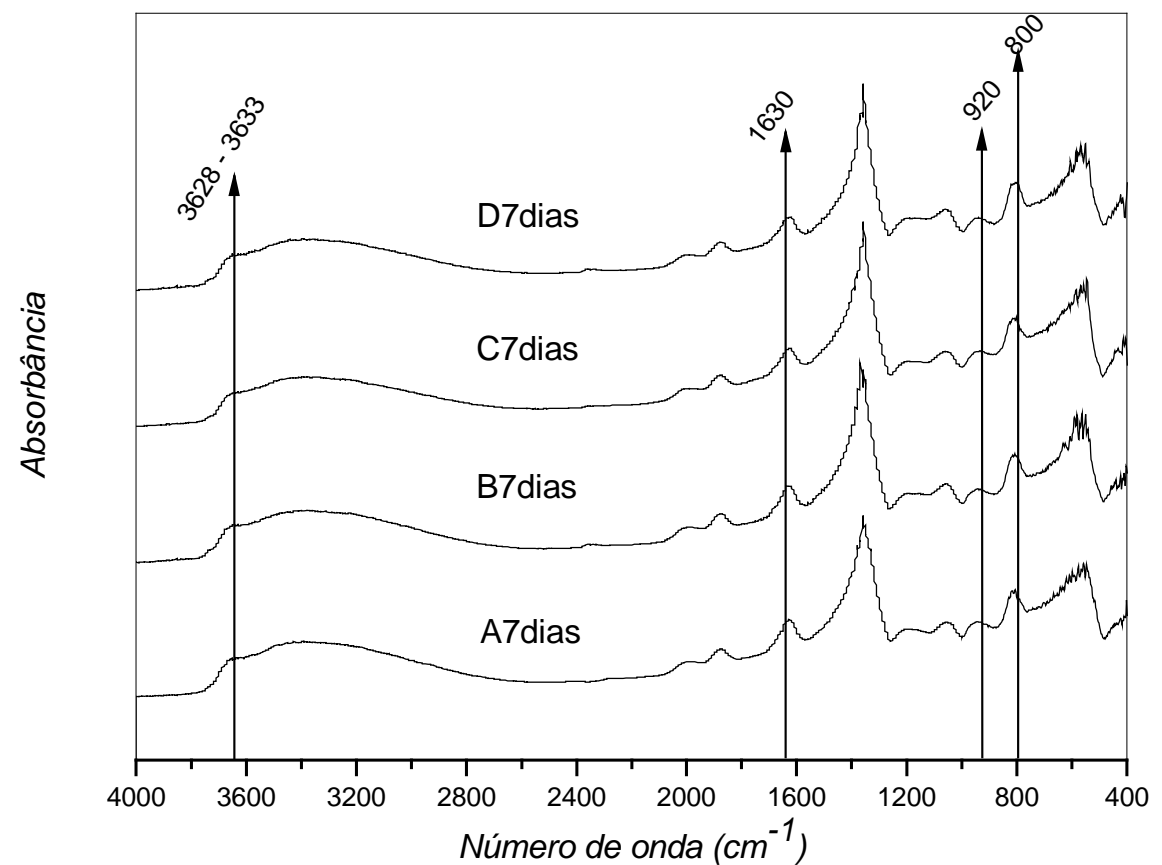

Figura 5.2.10 - Espectroscopia na região do infravermelho das amostras A, B, C e D ativadas com tempo de reação de 7 dias. 
Observa-se que a intensidade dos picos característicos diminuiu com a intensidade do tratamento e alguns desapareceram, indicando que o tratamento foi severo, estando este resultado também em conformidade com a difração de raios- $X$.

\subsection{Análises Térmicas: TG, DTG e DTA}

Os resultados das análises térmicas das amostras ativadas, com tempo de reação de 1, 2 e 3 horas, estão apresentados na Figuras 4.3.1 a 4.3.6.

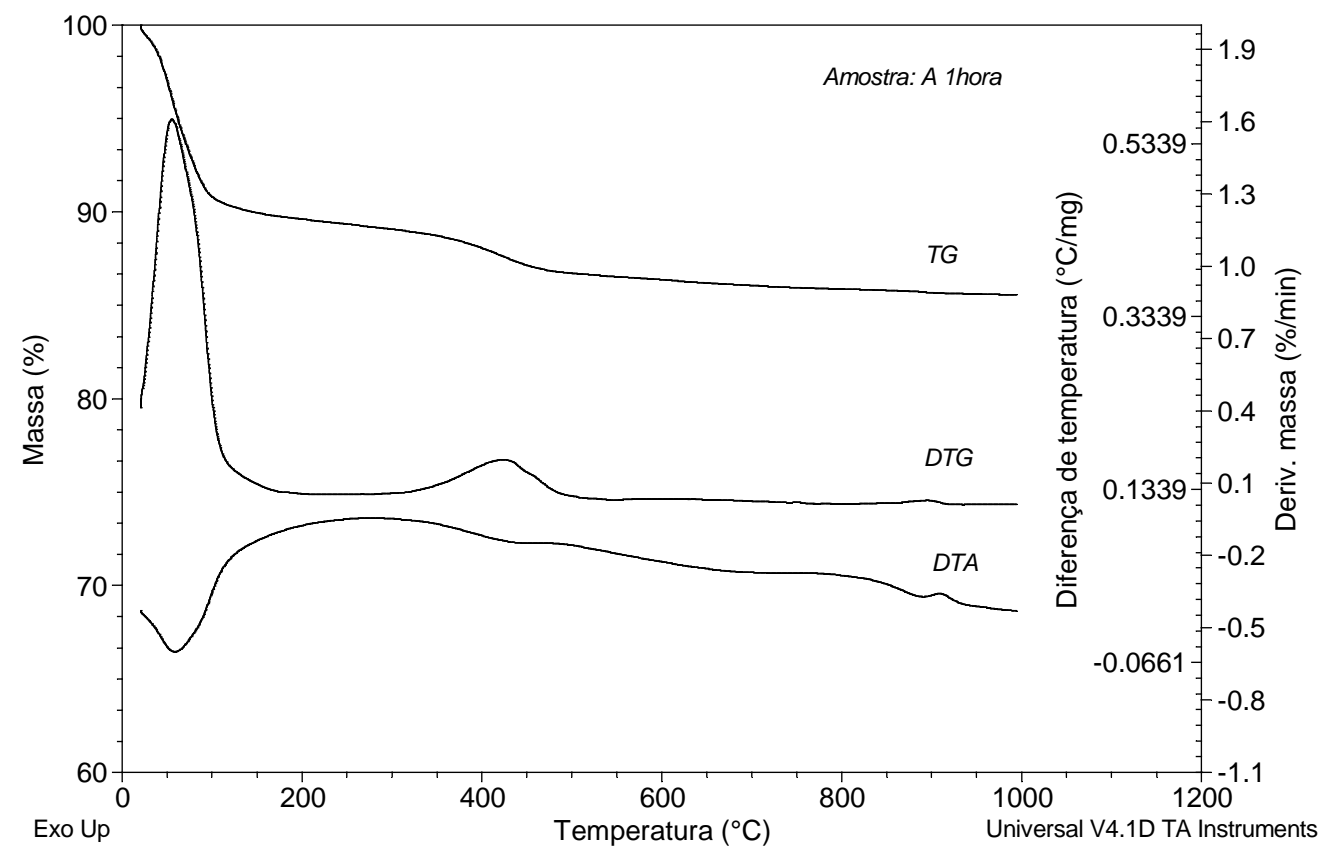

Figura 5.3.1 - Curvas TG, DTG e DTA da amostra A, ativada com tempo de reação de 1 hora. 


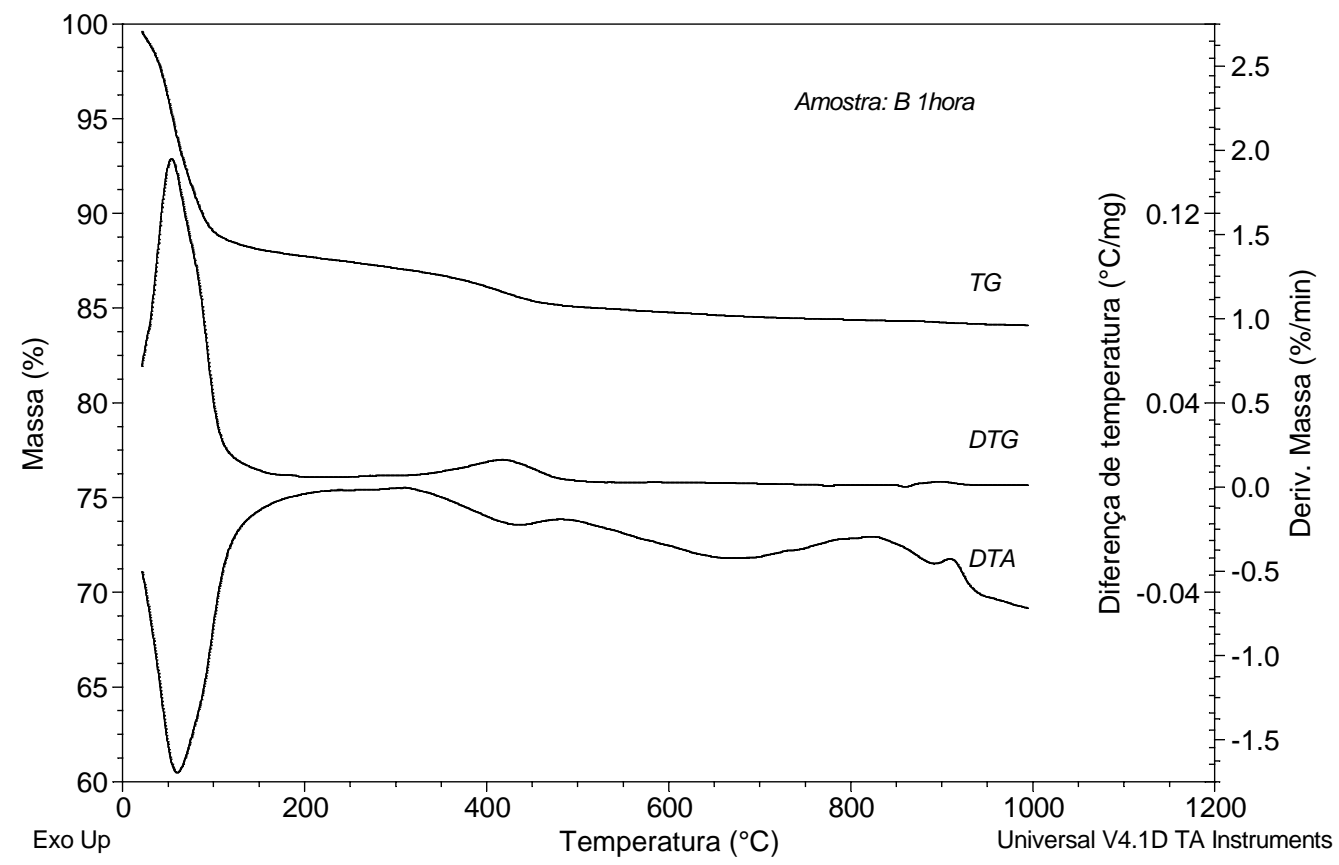

Figura 5.3.2 - Curvas TG, DTG e DTA da amostra B, ativada com tempo de reação de 1 hora.

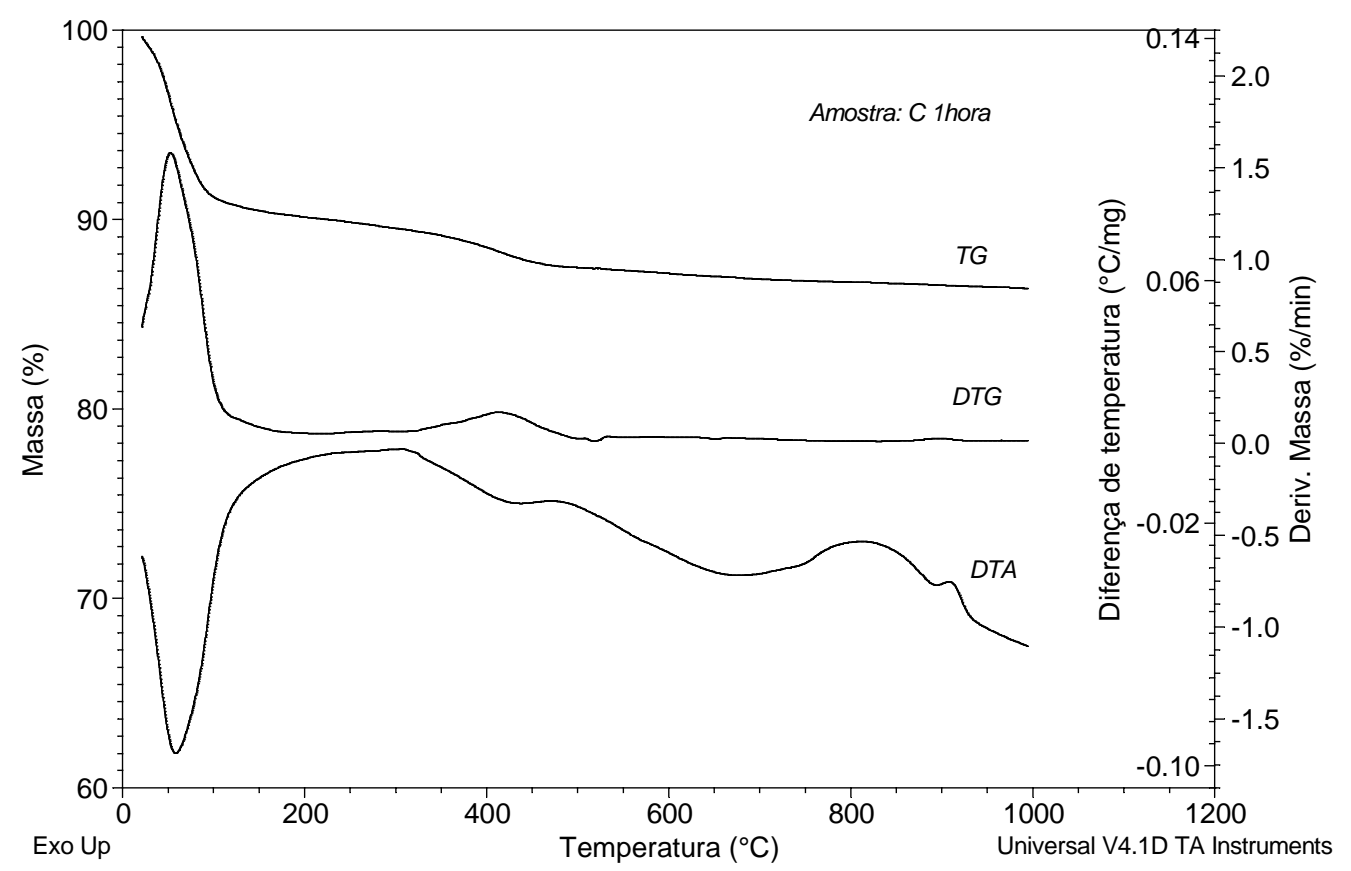

Figura 5.3.3 - Curvas TG, DTG e DTA da amostra C, ativada com tempo de reação de 1 hora. 


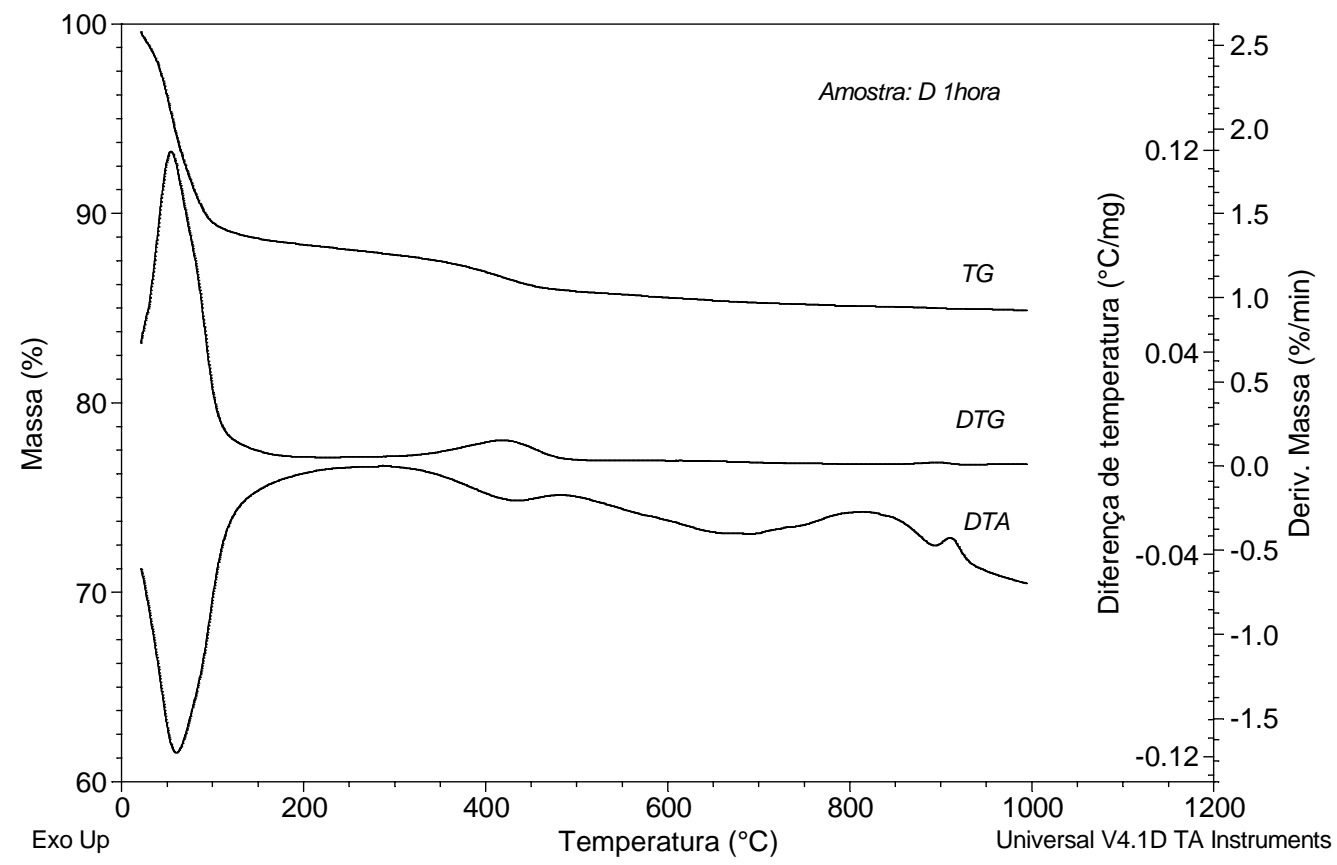

Figura 5.3.4 - Curvas TG, DTG e DTA da amostra D, ativada com tempo de reação de 1 hora.

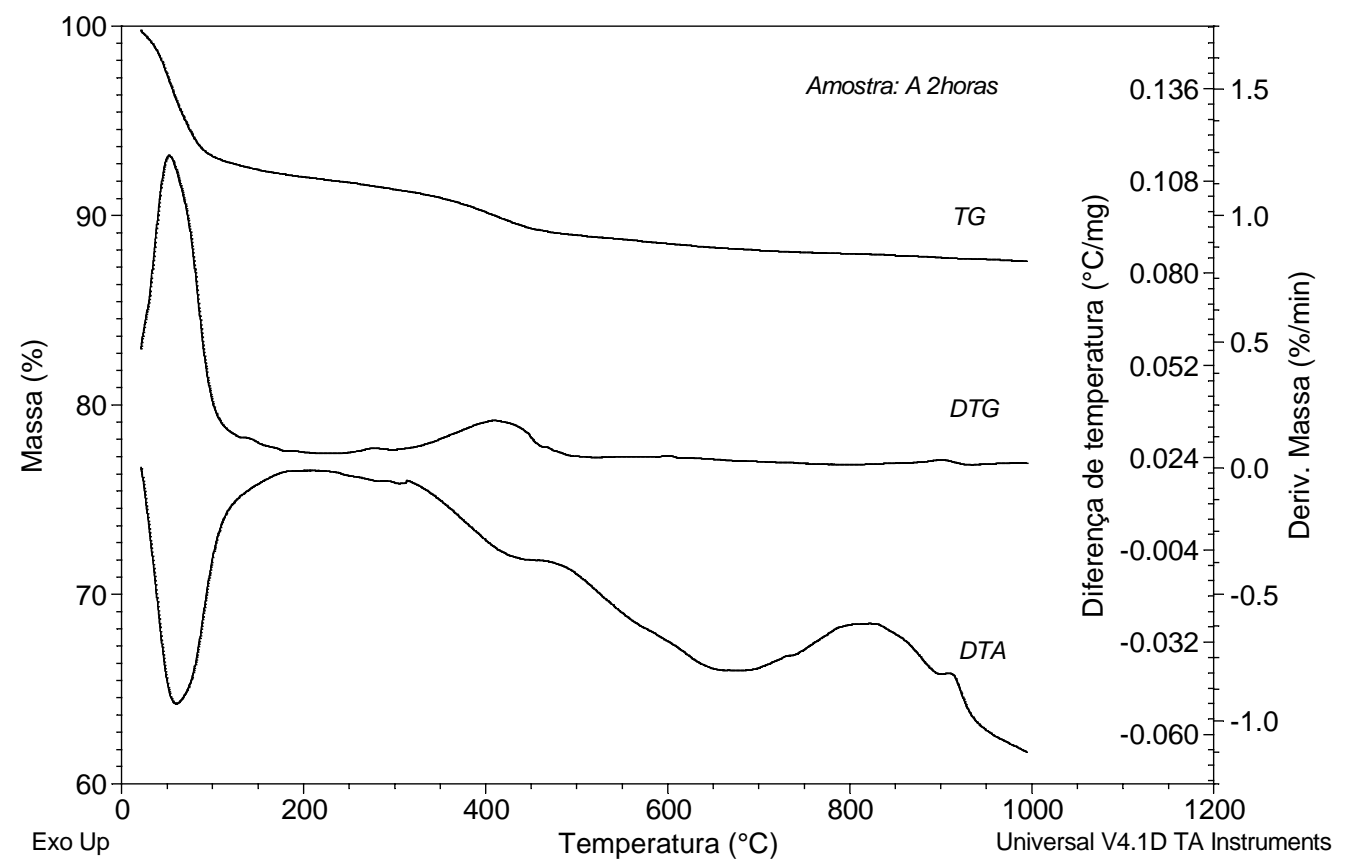

Figura 5.3.5 - Curvas TG, DTG e DTA da amostra A, ativada com tempo de reação de 2 horas. 


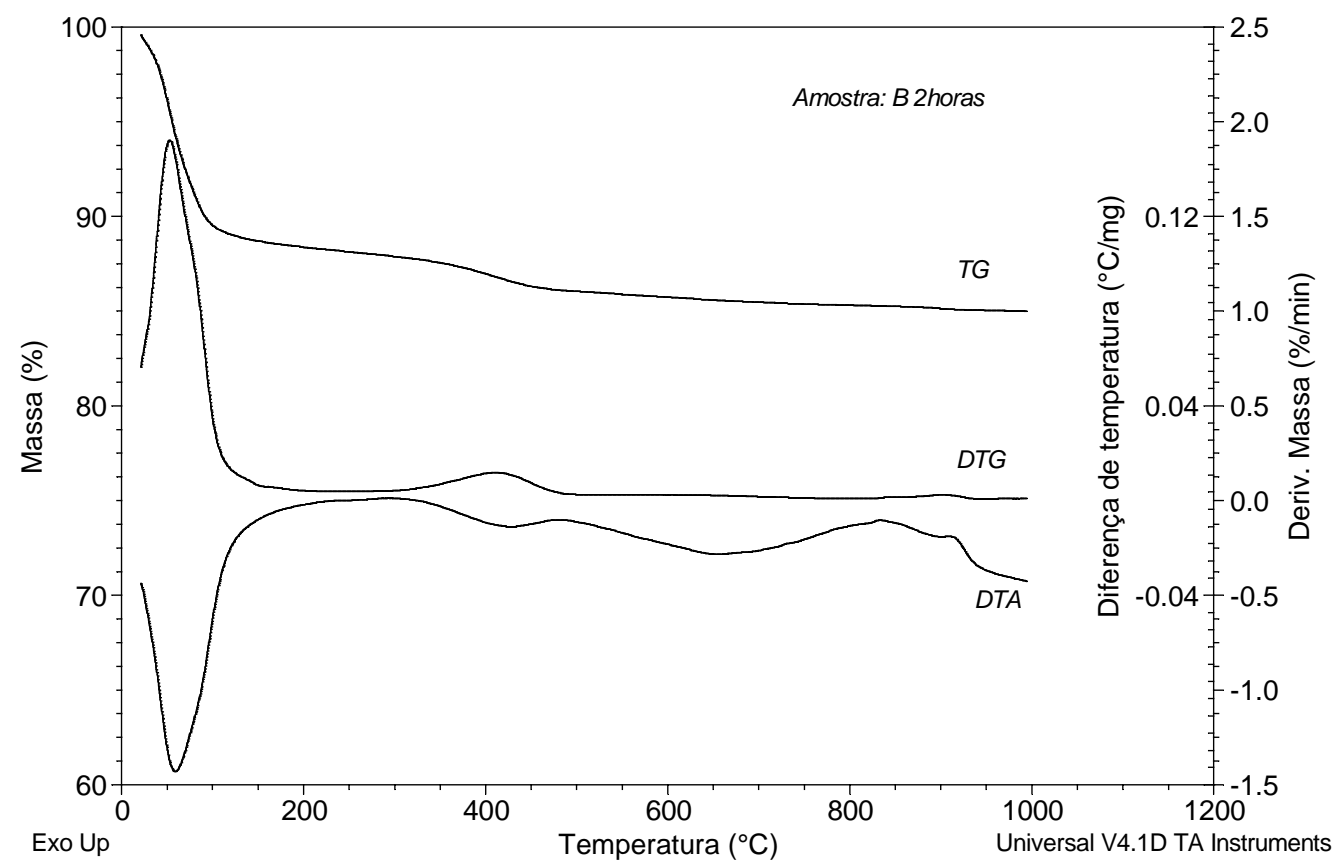

Figura 5.3.6 - Curvas TG, DTG e DTA da amostra B, ativada com tempo de reação de 2 horas.

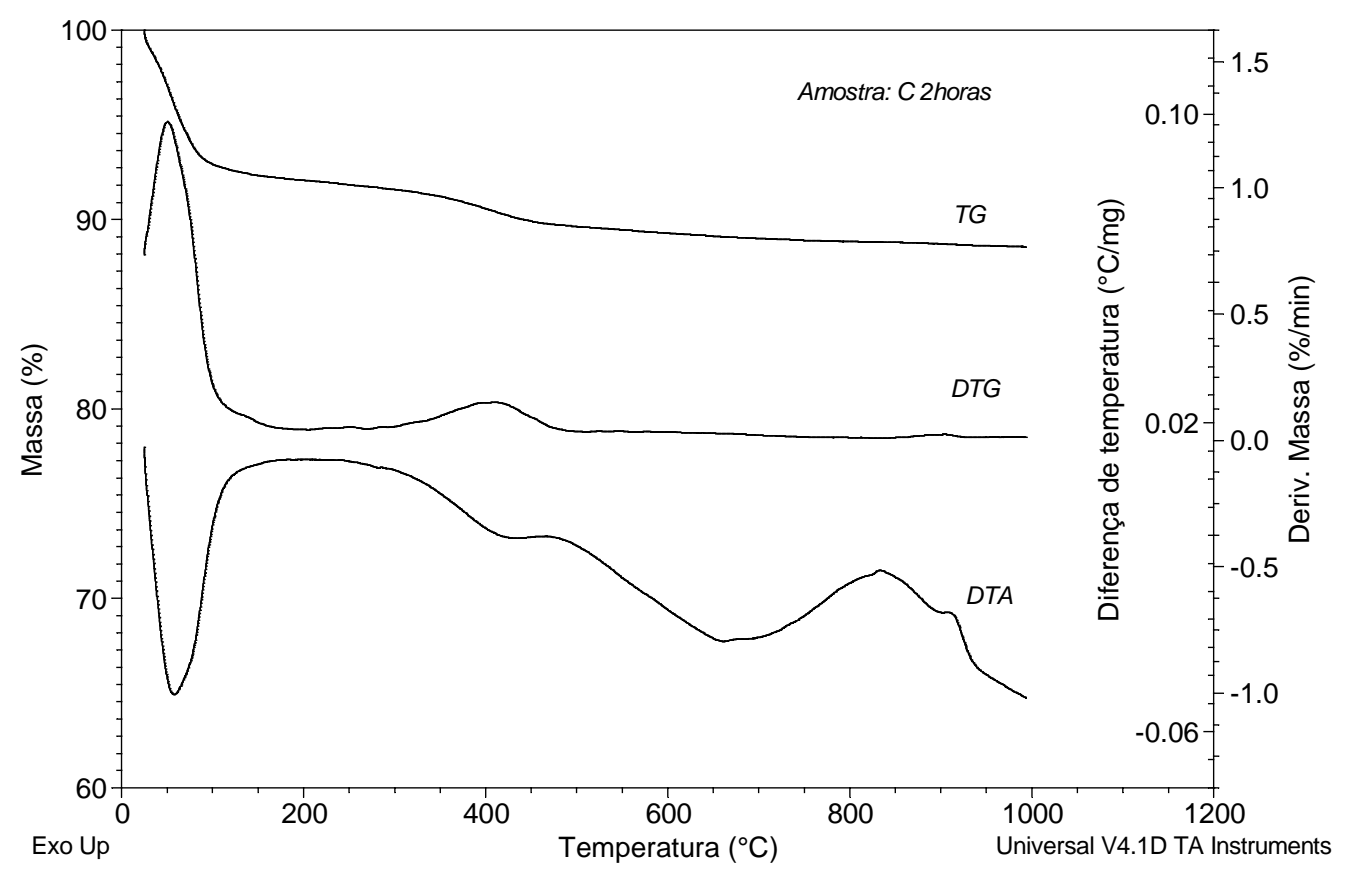

Figura 5.3.7 - Curvas TG, DTG e DTA da amostra C, ativada com tempo de reação de 2 horas. 


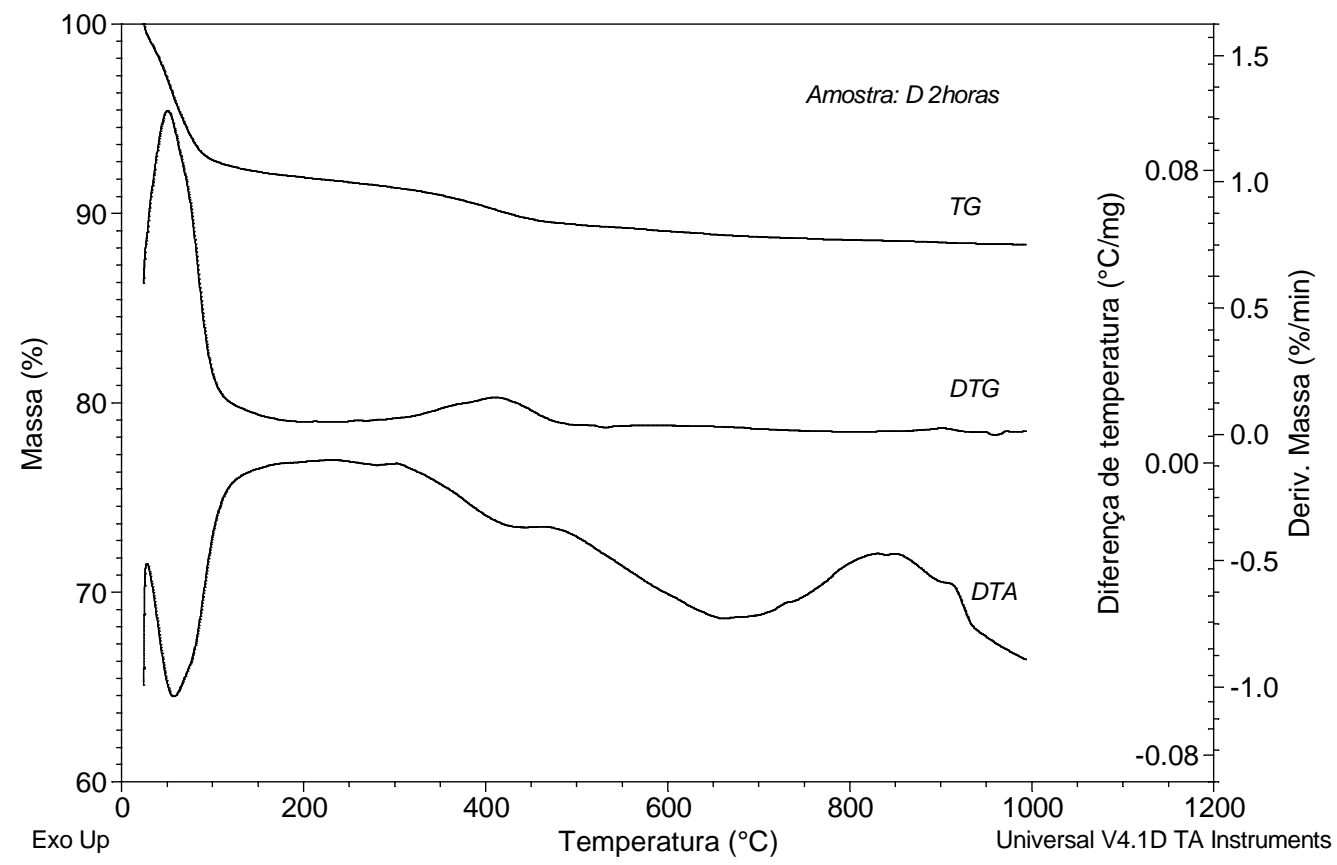

Figura 5.3.8 - Curvas TG, DTG e DTA da amostra D, ativada com tempo de reação de 2 horas.

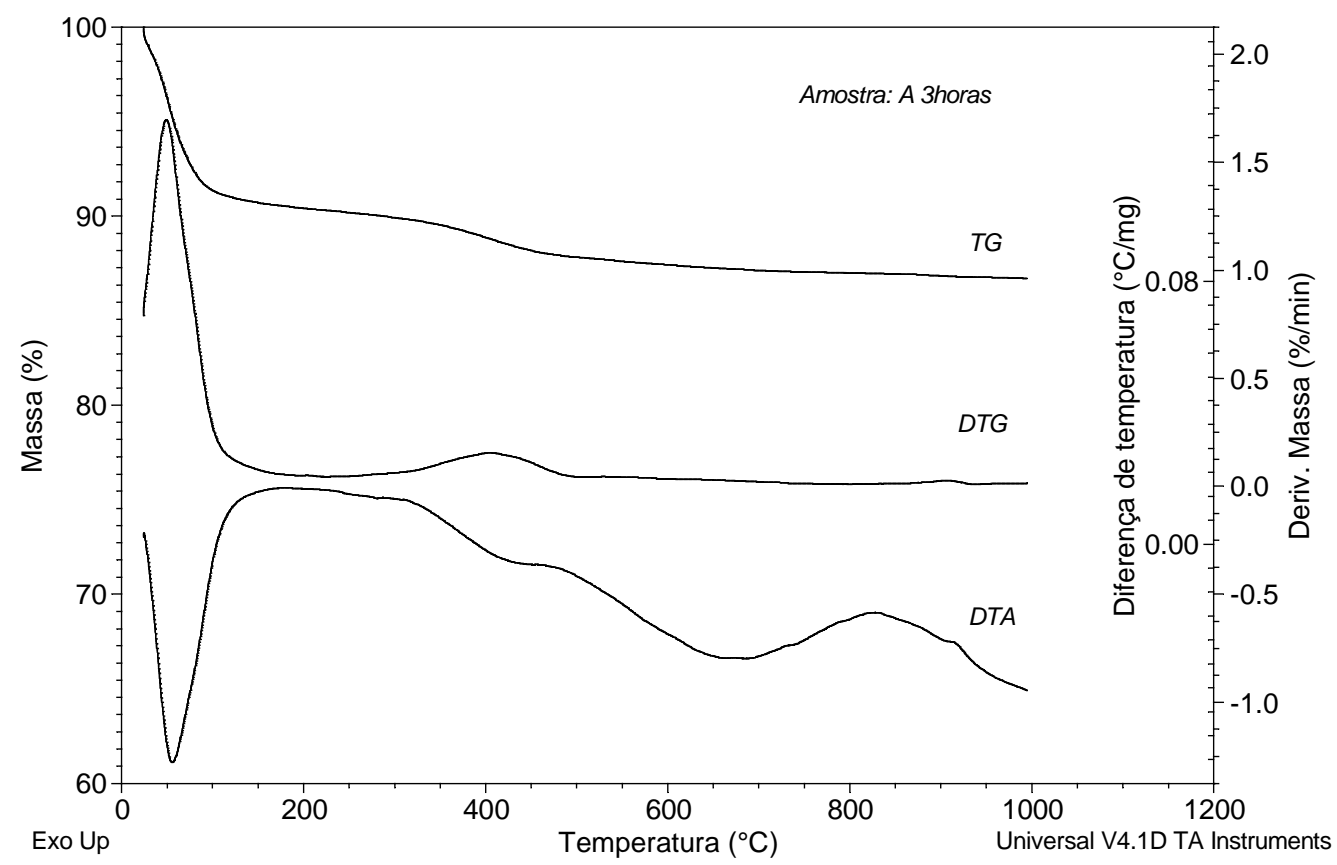

Figura 5.3.9 - Curvas TG, DTG e DTA da amostra A, ativada com tempo de reação de 3 horas. 


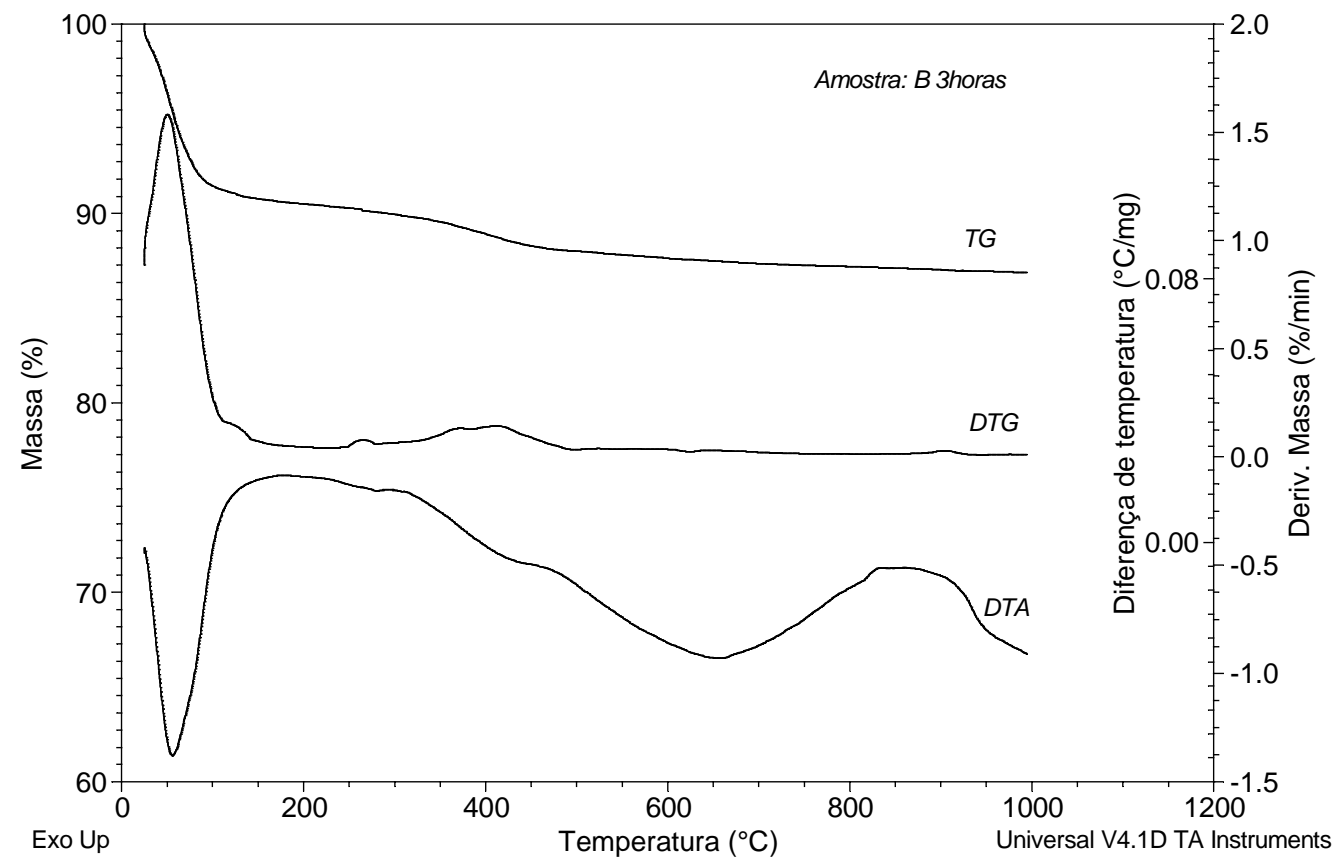

Figura 5.3.10 - Curvas TG, DTG e DTA da amostra B, ativada com tempo de reação de 3 horas.

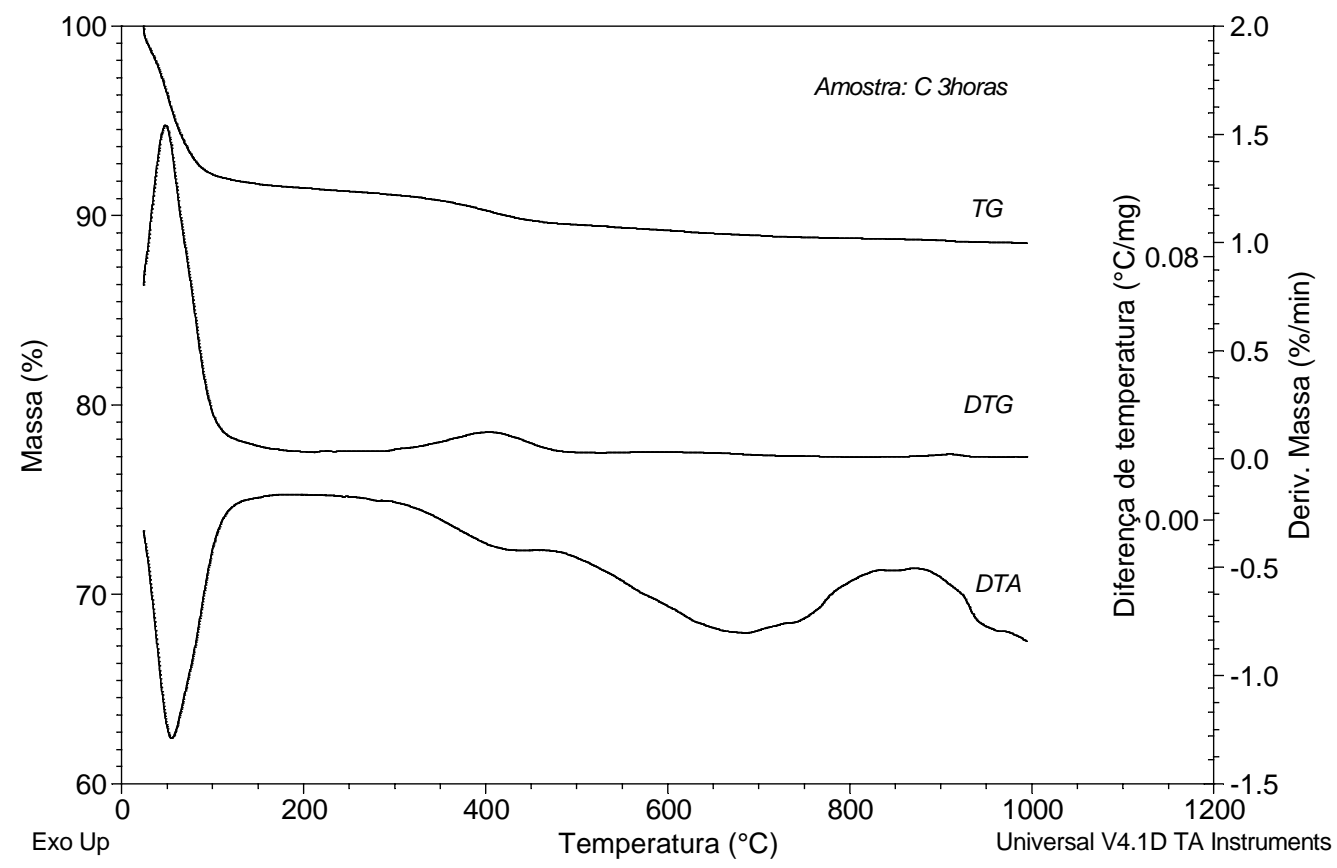

Figura 5.3.11 - Curvas TG, DTG e DTA da amostra C, ativada com tempo de reação de 3 horas. 


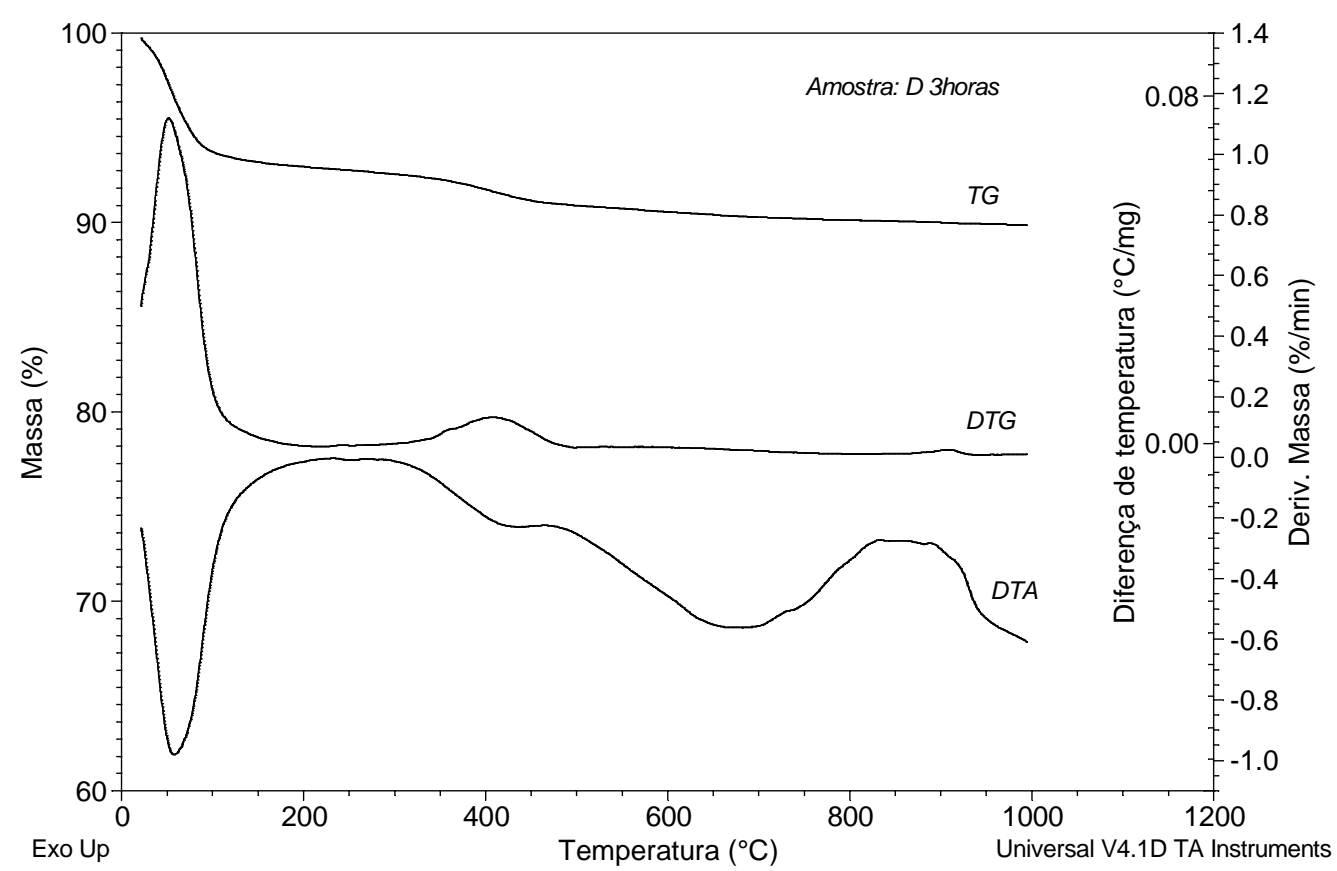

Figura 5.3.12 - Curvas TG, DTG e DTA da amostra D, ativada com tempo de reação de 3 horas.

Tabela 5.3.1 - Perdas de massa total das argilas ativadas A, B, C e D, com tempo de reação de 1,2 e 3 horas.

\begin{tabular}{c|c}
\hline Amostra & $\begin{array}{c}\text { Perda de massa total } \\
\text { (\%) }\end{array}$ \\
\hline A1hora & 14,4 \\
B1hora & 15,4 \\
C1hora & 13,6 \\
D1hora & 15,0 \\
& \\
A2horas & 11,9 \\
B2horas & 11,1 \\
C2horas & 11,4 \\
A2horas & 11,4 \\
& \\
A3horas & 13,2 \\
B3horas & 13,0 \\
C3horas & 11,4 \\
D3horas & 9,9 \\
\hline
\end{tabular}

Os valores de perda de massa total estão apresentados na Tabela 5.3.1, observa-se que estes variaram entre 9,9\% e 15,4\%. Em relação a amostra natural, verificou-se que as amostras ativadas com os tempos de reação de 1, 2 e 3 horas apresentaram perda de massa um pouco inferior. 


\subsection{Descoramento}

Este teste não foi realizado com as amostras ativadas com tempos de reação superiores aos de 1, 2 e 3 horas, visto que, nestes casos, foi realizado apenas o estudo para verificar o comportamento estrutural das amostras.

O teste de descoramento foi realizado em óleo de soja, segundo metodologia utilizada por Valenzuela Díaz e Souza Santos [2000] e visa verificar a eficiência da argila tratada no descoramento deste óleo. As Tabelas 5.4.1 e 5.4.2 apresentam os resultados do teste.

Tabela 5.4.1 - Porcentagem de descoramento de óleo de soja das amostras naturais e comerciais.

\begin{tabular}{|c|c|c|}
\hline Amostra & Absorbância & $\begin{array}{c}\text { Eficiência } \\
(\%)\end{array}$ \\
\hline \multicolumn{3}{|l|}{ Naturais } \\
\hline$A$ & 0,08 & 75,2 \\
\hline B & 0,09 & 73,3 \\
\hline $\mathrm{C}$ & 0,10 & 68,7 \\
\hline D & 0,09 & 73,3 \\
\hline \multicolumn{3}{|l|}{ Comerciais } \\
\hline Tonsil & 0,12 & 63,6 \\
\hline Alclor & 0,13 & 60,4 \\
\hline
\end{tabular}

Tabela 5.4.2 - Porcentagem de descoramento de óleo de soja das amostras A, B, C e D ativadas com os tempos de reação de 1, 2 e 3 horas.

\begin{tabular}{c|c|c}
\hline Amostra & Absorbância & $\begin{array}{c}\text { Eficiência } \\
\text { (\%) }\end{array}$ \\
\hline A1hora & 0,14 & 58,5 \\
B1hora & 0,08 & 74,8 \\
C1hora & 0,12 & 74,7 \\
D1hora & 0,12 & 63,0 \\
& & \\
A2horas & 0,13 & 60,8 \\
B2horas & 0,12 & 63,0 \\
C2horas & 0,13 & 61,4
\end{tabular}




\begin{tabular}{c|c|c} 
A2horas & 0,14 & 58,3 \\
& & \\
A3horas & 0,08 & 77,0 \\
B3horas & 0,09 & 71,6 \\
C3horas & 0,08 & 74,7 \\
D3horas & 0,07 & 77,9 \\
\hline \multicolumn{2}{c}{${ }^{*}$ A absorbância medida do óleo de soja foi de 0,33}
\end{tabular}

A determinação do descoramento de óleo de soja foi feita através da avaliação da cor por métodos ópticos em espectrofotômetro e a eficiência foi dada pela equação descrita no item: 3.3.1.2. Teste de descoramento de óleo (Capítulo 3 Materiais e métodos).

A absorbância do óleo descorado pelas amostras testadas é comparada com a absorbância do mesmo óleo descorado por 2 argilas de referência: Tonsil e Alclor. Quanto menor a absorbância melhor será seu descoramento, com isso observamos que:

a) As amostras naturais apresentam eficiência no descoramento de 68,7 a $75,3 \%$

b) As amostras comerciais Tonsil e Alclor apresentaram eficiência de 63,6 e $60,4 \%$, respectivamente.

c) As amostras ativadas com tempo de reação de 1 hora apresentaram resultados variando de 58,5 a $74,8 \%$.

d) As amostras ativadas com tempo de reação de 2 horas apresentaram eficiência que variou entre 58,3 a $63 \%$.

e) As amostras ativadas com tempo de reação de 3 horas apresentaram resultados que variam entre 71,6 e $77,9 \%$.

Com estes resultados é possível verificar que a amostra sem tratamento apresentou alta eficiência no descoramento, comportando-se como Terra Fuller, que são argilas montmoriloníticas ou paligorsquíticas que, em estado natural, possuem poder descorante apreciável para óleos orgânicos, especialmente óleos vegetais, sendo que estas argilas foram utilizadas durante muito tempo como descorantes na indústria do petróleo [SOUZA SANTOS, 1989]. 
Verificou-se que, para as amostras ativadas, os melhores resultados de descoramento foram apresentados para as amostras ativadas com tempo de reação de 3 horas, porém, valores muito parecidos foram obtidos com as argilas ativadas por 1 hora.

Verifica-se ainda que todas as amostras, tanto naturais quanto ativadas, apresentaram poder descorante consideravelmente maior que os obtidos pelas argilas comerciais Tonsil e Alclor, as quais são consideradas como argilas ativadas de alta qualidade pelas indústrias, a nível mundial, usuárias de processos de descoramento.

Em estudo realizado por Pereira [2003] com argila proveniente do Estado da Paraíba, foi verificado que a mesma, com e sem tratamento ácido, apresentou poder descorante, no mesmo óleo.

Morgado [1998], também realizou estudo sobre ativação ácida com argila proveniente de Santa Catarina e verificou no teste de descoramento de óleo que a amostra estudada, sem tratamento, apresentou poder descorante em óleo de soja, girassol e milho.

Visando verificar a eficiência no descoramento de óleos de soja e milho, Pereira et al. [2004] realizou tratamento ácido com ácido clorídrico e sulfúrico em argila esmectítica da Paraíba. Neste estudo, os autores utilizaram condições similares as desta Tese, porém as amostras ativadas com os dois ácidos, em relação as estudadas neste trabalho de Tese, apresentaram eficiência no descoramento do óleo de milho e baixa eficiência no descoramento do óleo de soja. 


\section{CAPÍTULO 6}

\section{Resultados e discussão Argilas Organofílicas}

No capítulo 6 serão apresentados e discutidos os resultados obtidos no estudo da organofilização. 


\subsection{Difração de Raios-X (DRX)}

Na Figura 6.1.1 estão apresentados os difratogramas de raios- $X$ das amostras A, B, C e D tratadas com o sal quaternário 1.
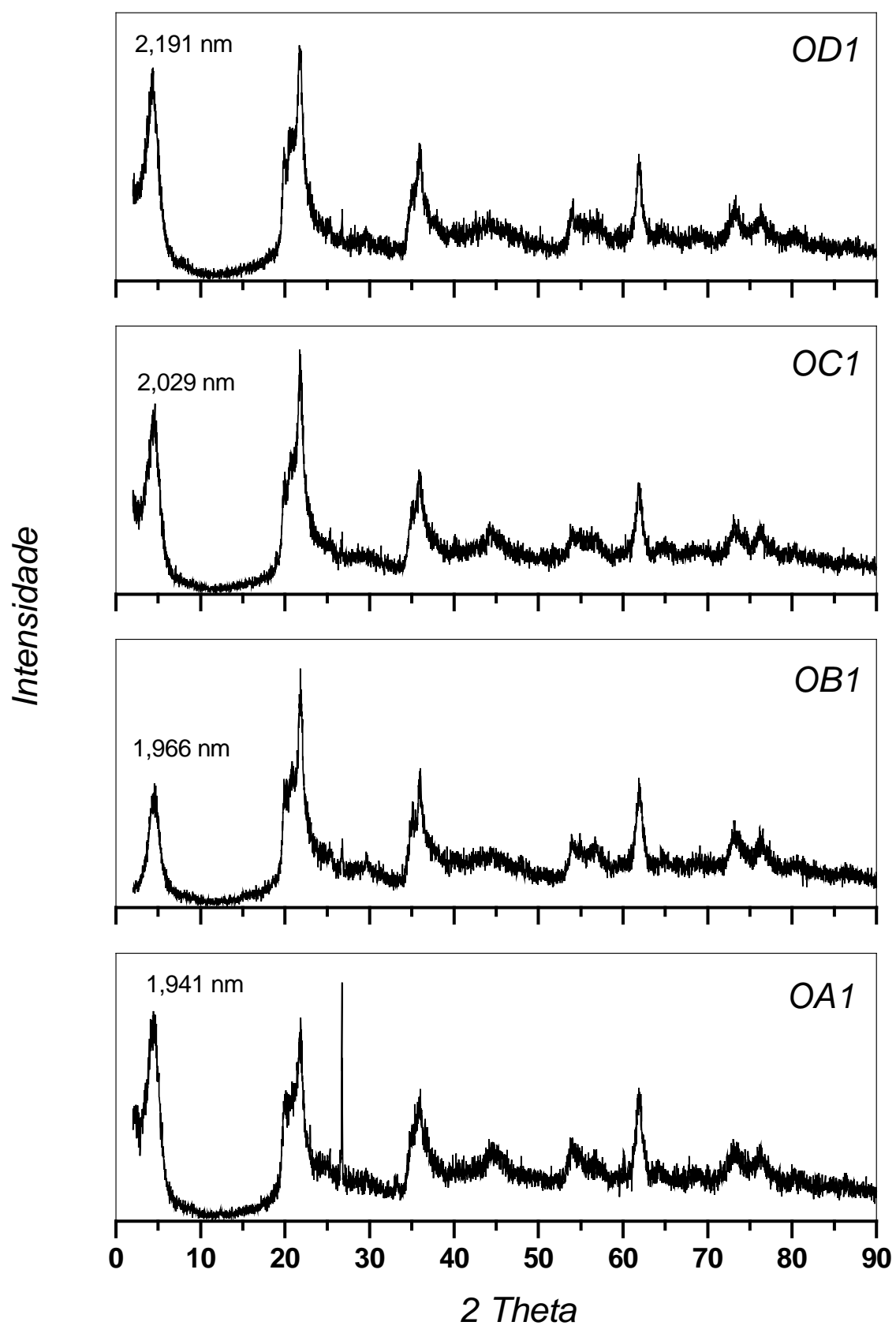

Figura 6.1.1 - Difratogramas das amostras A, B, C e D tratadas com sal quaternário 1. 
Observa-se nos difratogramas que os resultados de espaçamento basal $\left(\mathrm{d}_{001}\right)$ das amostras tratadas com o sal quaternário 1 são de: $1,94 \mathrm{~nm}$ para amostra $A$; $1,96 \mathrm{~nm}$ para amostra $B ; 2,03 \mathrm{~nm}$ para amostra $C$ e a amostra $D$ apresentou espaçamento de $2,19 \mathrm{~nm}$.

Em relação à amostra natural (Figura 4.1.1), estes apresentaram aumento na $\mathrm{d}_{001}$, indicando que o cátion quaternário foi intercalado nas camadas interlamelares da argila. De acordo com Lagaly [1982] e Jaynes e Boyd [1991], estas argilas indicam existência de bicamada e camada pseudotrimolecular.

A Figura 6.1.2 apresenta os difratogramas de raios- $X$ das amostras $A, B, C$ e D tratadas com o sal quaternário 2. 


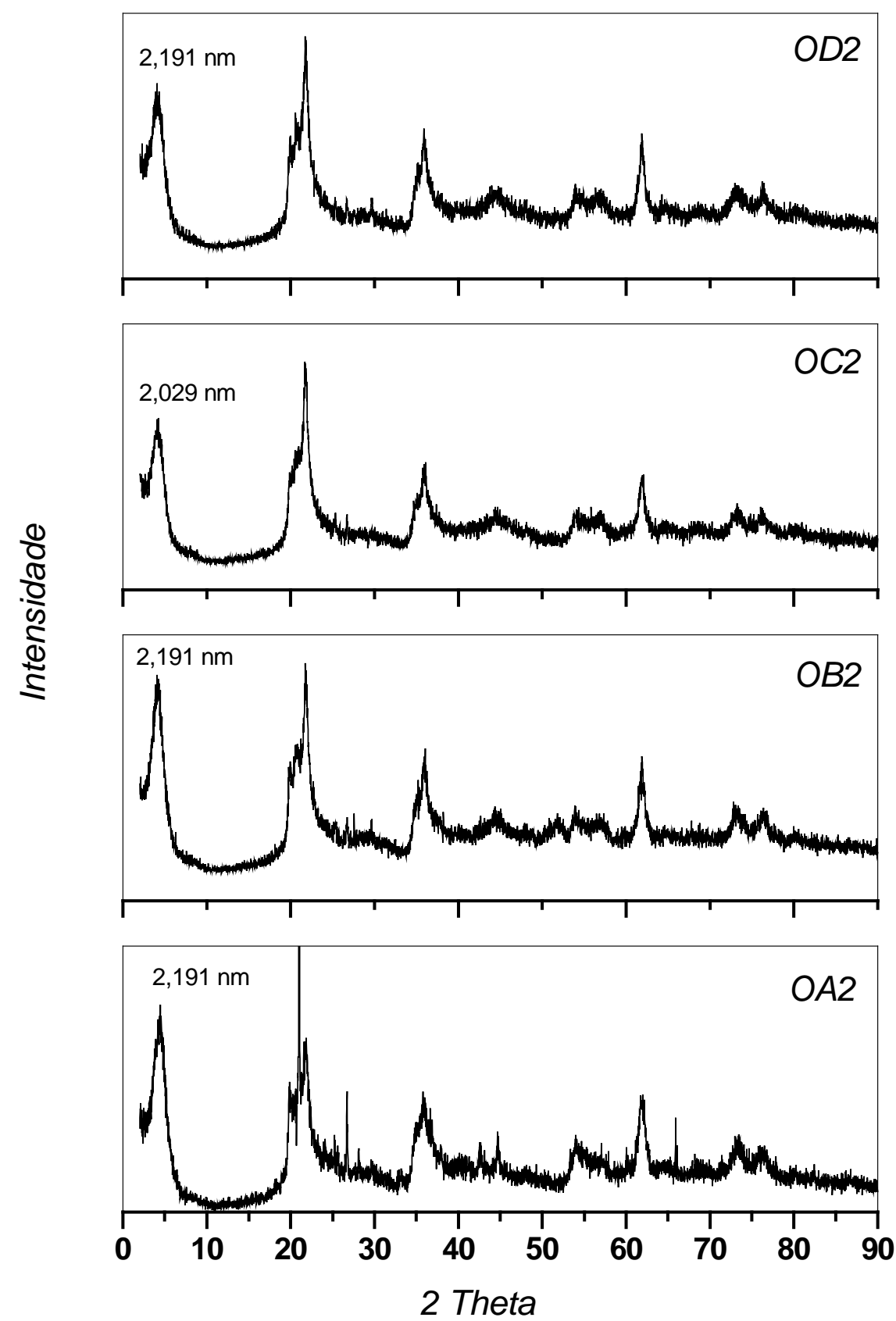

Figura 6.1.2 - Difratogramas das amostras A, B, C e D tratadas com sal quaternário 2.

Observa-se na Figura 6.1.2 que as amostras A, B, C e D, apresentaram espaçamento basal, respectivamente, de: 2,19nm; 2,19nm; 2,03nm e 2,19nm. Verifica-se que, em relação ao sal 1, estas amostras apresentaram espaçamento basal superior e formação de camada pseudotrimolecular [LAGALY, 1982; JAYNES e BOYD, 1991]. 
Na Figura 6.1.3 apresentam-se os difratogramas de raios- $X$ das amostras $A$, B, C e D tratadas com o sal quaternário 3.
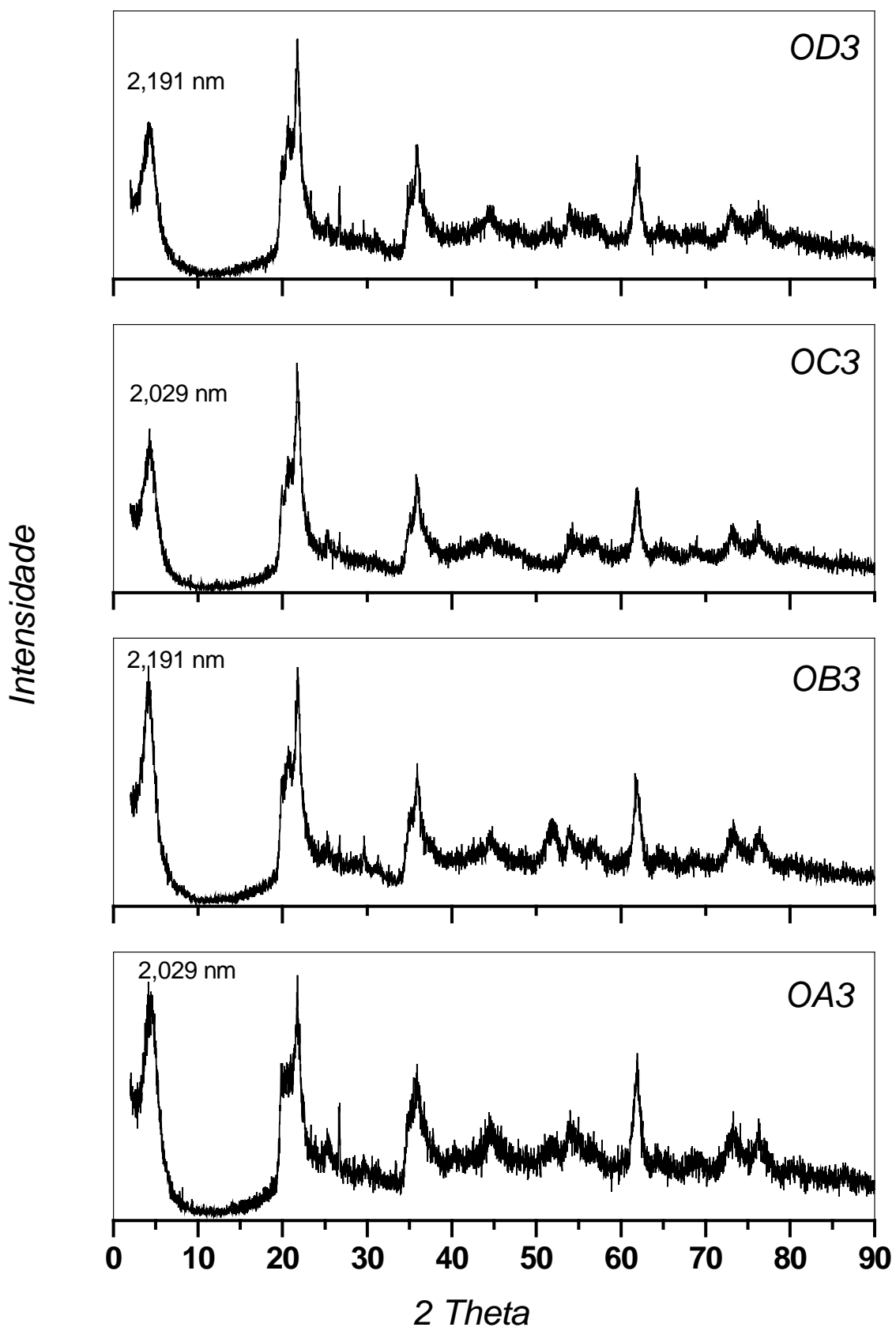

Figura 6.1.3 - Difratogramas das amostras A, B, C e D tratadas com sal quaternário 3. 
Observa-se nos difratogramas que as amostras tratadas com 0 sal quaternário 3 , apresentaram comportamento idêntico às amostras tratadas com o sal 2 e praticamente o mesmo valor de espaçamento basal.

Utilizando a mesma metodologia deste trabalho, Pereira; Rodrigues; Valenzuela Díaz [2007] e Pereira et al. [2004], verificaram que a proposta de uma metodologia que diminua o tempo de preparação foi efetuado com sucesso no sentido de obter-se materiais estruturalmente similares.

\subsection{Espectroscopia na Região do Infravermelho (FTIR)}

As Figuras 6.2.1, 6.2.2 e 6.2.3 apresentam os espectros na região do infravermelho das amostras $A, B, C$ e $D$ tratadas com os sais 1,2 e 3 , respectivamente.

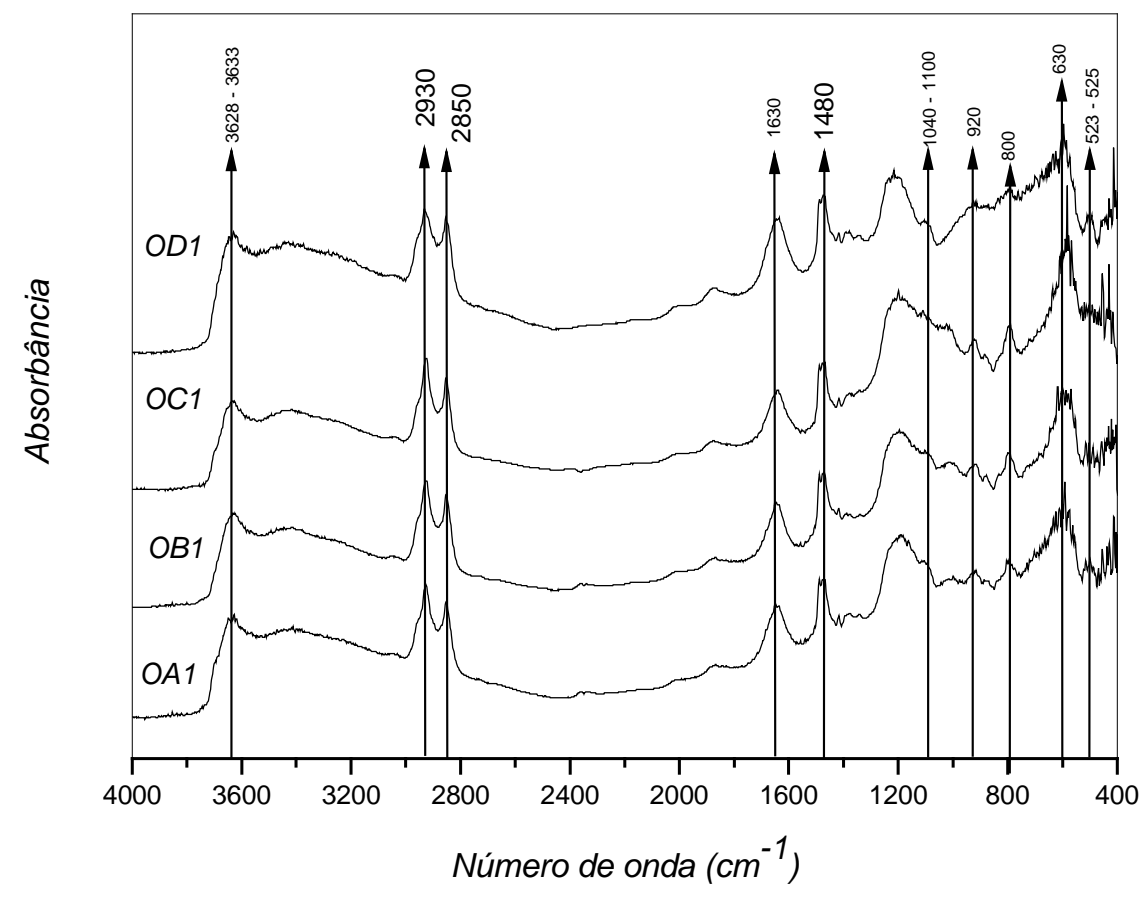

Figura 6.2.1 - Espectros na região do infravermelho das amostras A, B, C e D tratadas com sal quaternário 1. 


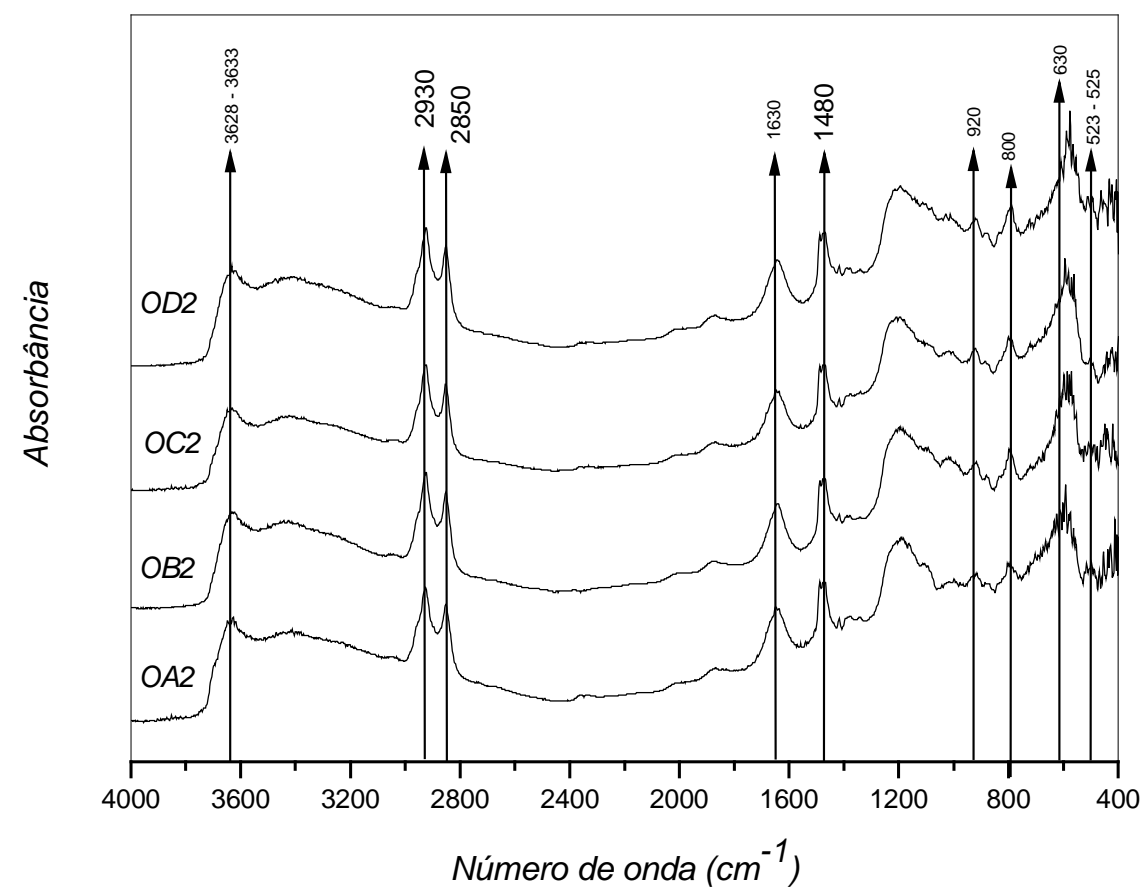

Figura 6.2.2 - Espectros na região do infravermelho das amostras A, B, C e D tratadas com sal quaternário 2 .

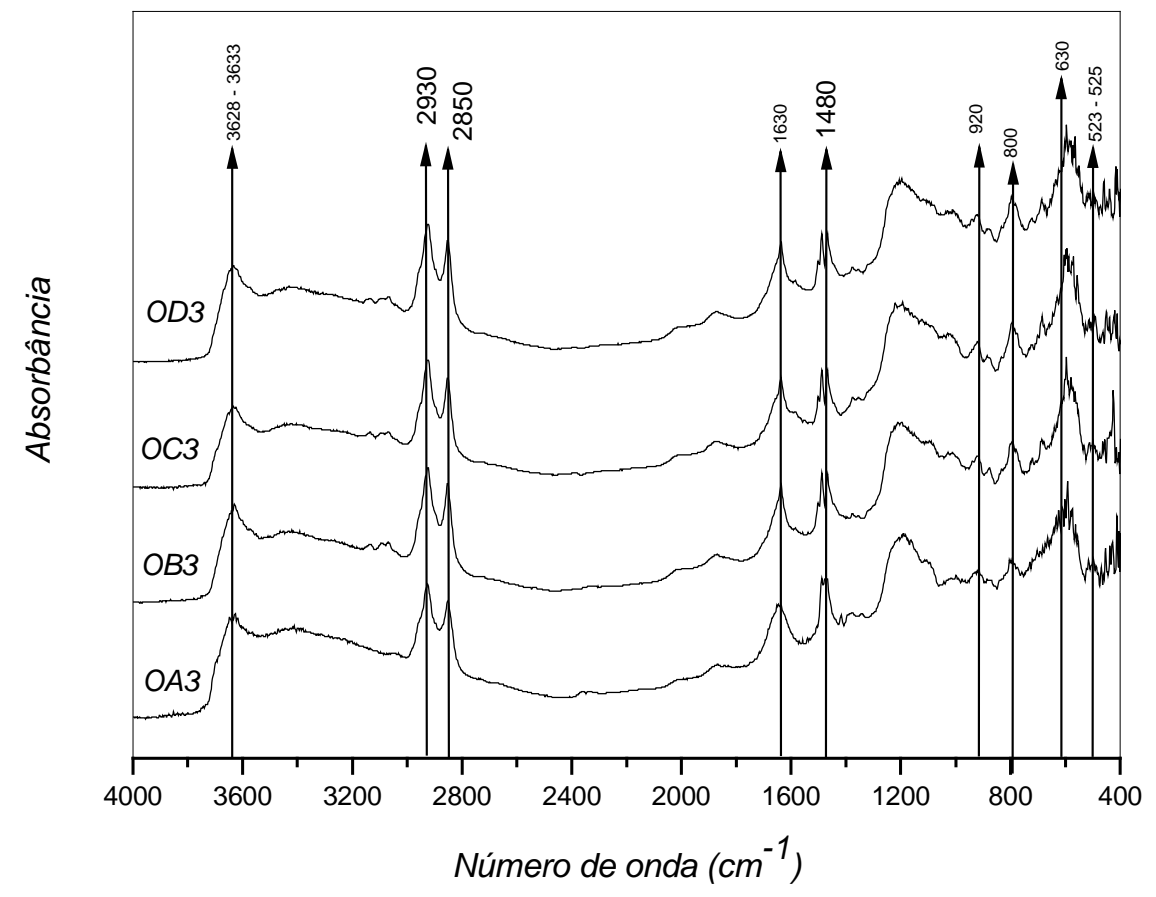

Figura 6.2.3 - Espectros na região do infravermelho das amostras A, B, C e D tratadas com sal quaternário 3 . 
As Figuras 6.2.1, 6.2.2 e 6.2.3 apresentam espectros na região do infravermelho das amostras tratadas com os sais quaternários na mesma faixa de absorção do comprimento de onda, independente do sal utilizado.

De acordo com Bala; Samantaray; Srivastava [2000] e Zhang et al. [2003], os picos que se encontram na faixa de $3628-3630 \mathrm{~cm}^{-1}$, indicam a presença de ligação $\mathrm{O}-\mathrm{H}$. As bandas nas faixas de $930-800 \mathrm{~cm}^{-1}, 630 \mathrm{~cm}^{-1}$ e $523-525 \mathrm{~cm}^{-1}$, são característicos das camadas octaédricas, ligações Al-O e ligações Si-O, respectivamente. Estes picos e bandas também estão presentes na amostra sem tratamento e isto indica que a estrutura, das mesmas, foi mantida.

O par de bandas nas faixas de $2850-2930 \mathrm{~cm}^{-1}$ são referentes a presença do grupo $\mathrm{CH}_{2}$ e o grupo $\mathrm{CH}_{3}$ ocorre na faixa de $1480 \mathrm{~cm}^{-1}$ [RAMOS VIANNA, et al., 2002], indicando assim a presença do cátion do sal quaternário.

\subsection{Análises Térmicas: TG, DTG e DTA}

As principais diferenças no comportamento térmico das argilas organofílicas são que a curva de TG mostra uma menor perda de água livre e/ou adsorvida que a argila original, bem como novo estágio de perda de massa devido à combustão da matéria orgânica, que fica caracterizado por pico exotérmico na curva DTA [YARIV; CROSS, 2002].

Segundo Yariv [2004] as curvas das análises térmicas de argilas organofílicas usualmente apresentam três regiões principais:

a. Região de secagem e desidratação, onde a água livre e/ou adsorvida é perdida, caracterizada por pico exotérmico na DTA, que ocorre no mesmo intervalo de temperatura no qual a argila natural é seca e desidratada, geralmente abaixo de $200^{\circ} \mathrm{C}$.

b. Região da pirólise da matéria orgânica, usualmente acima dos $200^{\circ} \mathrm{C}$, cujo efeito térmico mostrado pela curva DTA depende do tipo de gás de purga e das características dos orgânicos presentes na argila organofílica. Em atmosfera inerte, usualmente apenas picos 
endotérmicos são mostrados nas curvas DTAs, devido a volatilização e/ou decomposição durante a pirólise.

c. A terceira região mostra a desidroxilação da estrutura, a qual é caracterizada por pico endotérmico na curva DTA, ao qual usualmente seguem-se picos exotérmicos, devido às etapas de incineração do material carbonoso residual formado no estágio prévio da pirólise dos orgânicos.

As Figuras 6.3.1, 6.3.2, 6.3.3 e 6.3.4, mostram as curvas TG, DTG e DTA das argilas $A, B, C$ e $D$ tratadas com o sal quaternário 1.

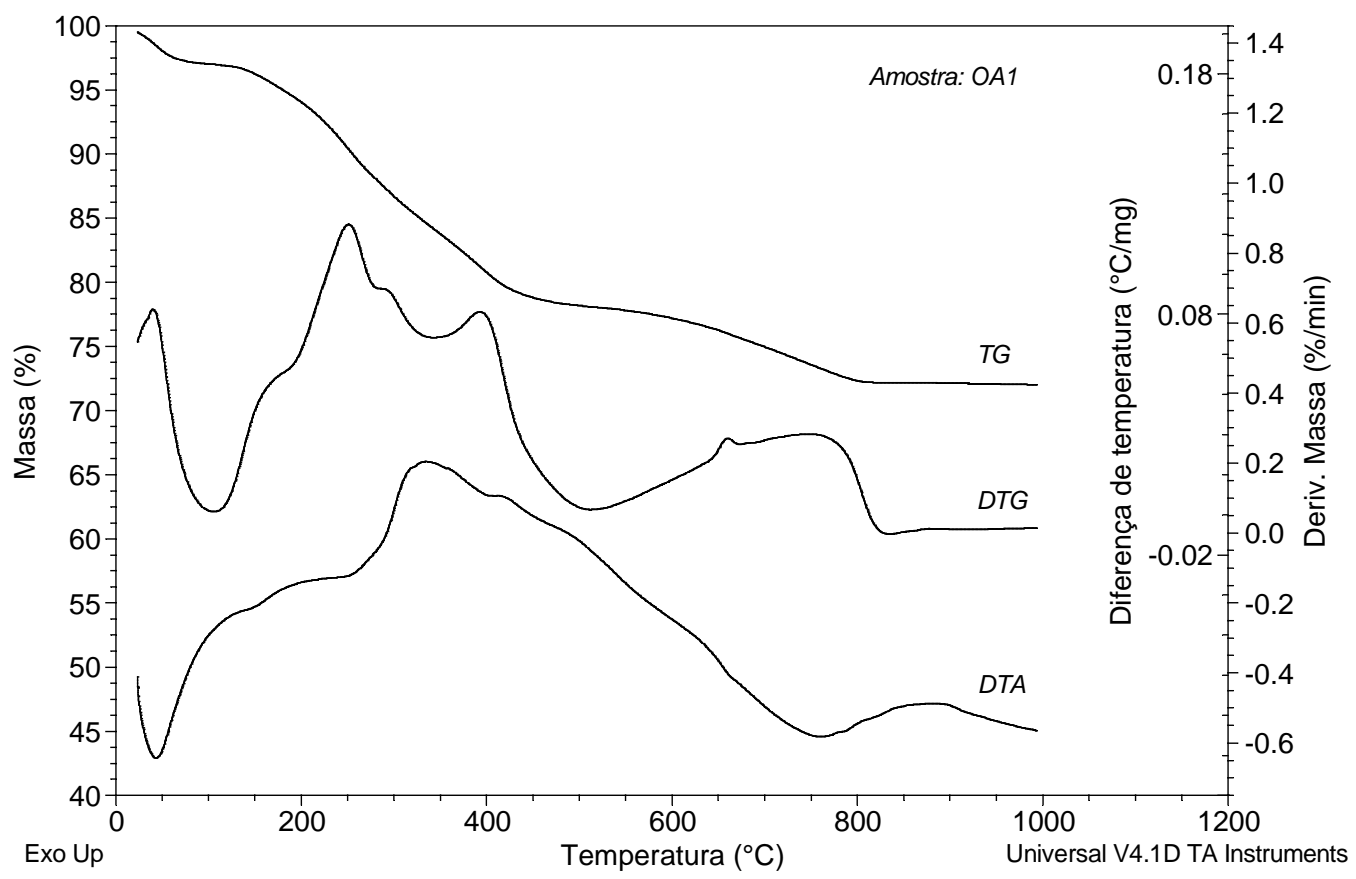

Figura 6.3.1 - Curvas TG, DTG e DTA da amostra A tratada com o sal quaternário 1. 


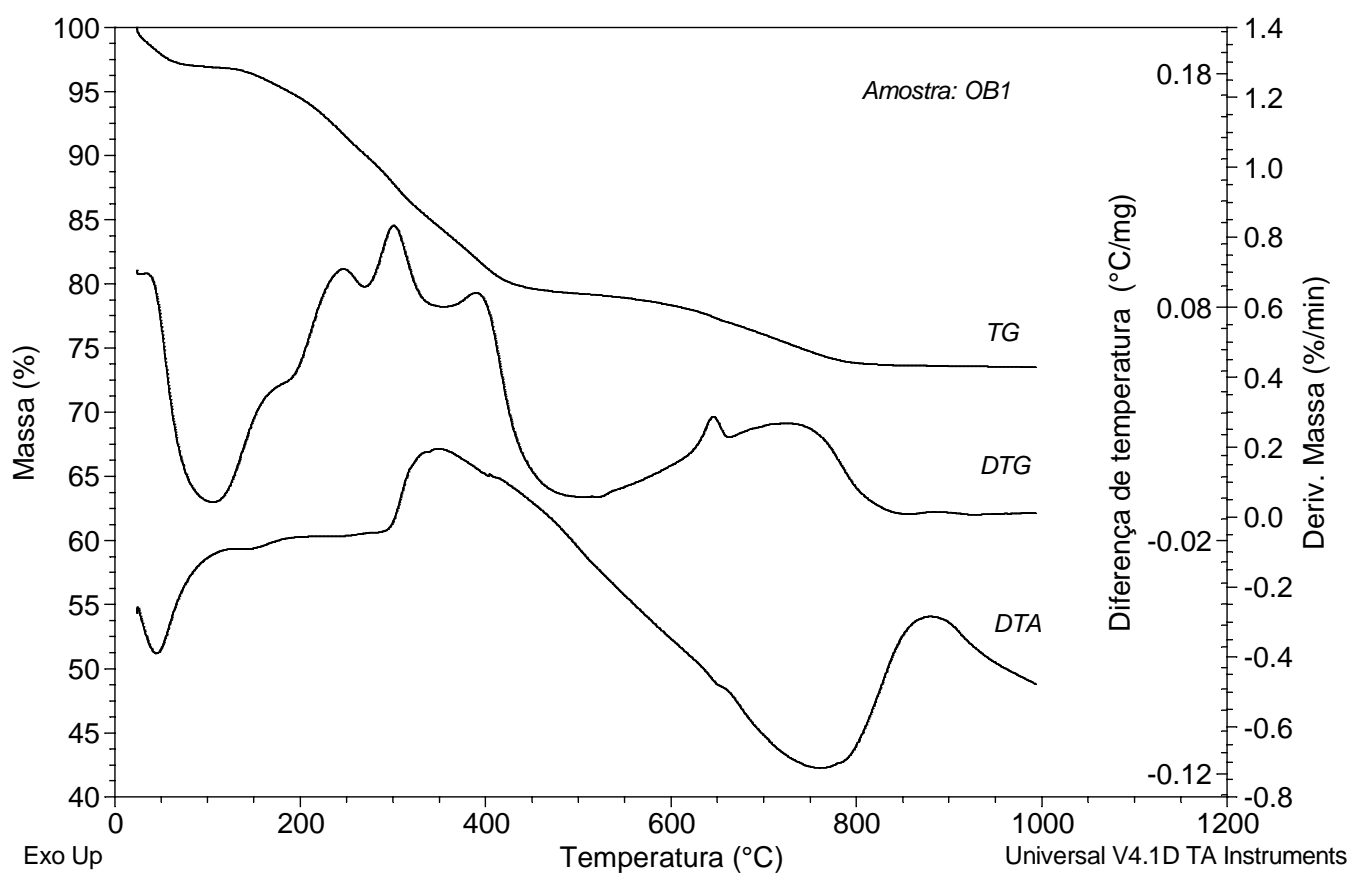

Figura 6.3.2 - Curvas TG, DTG e DTA da amostra B tratada com o sal quaternário 1.

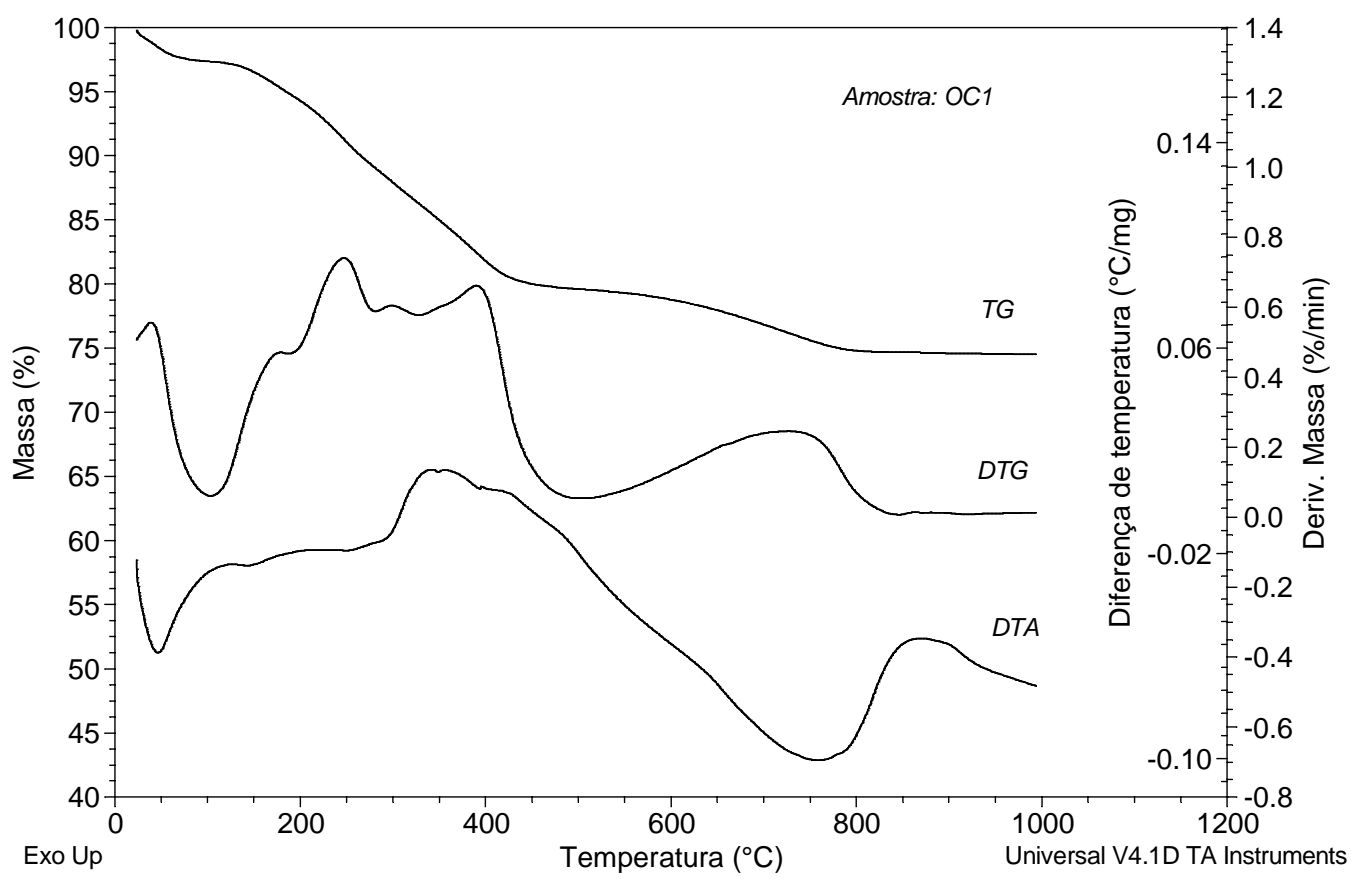

Figura 6.3.3 - Curvas TG, DTG e DTA da amostra C tratada com o sal quaternário 1. 


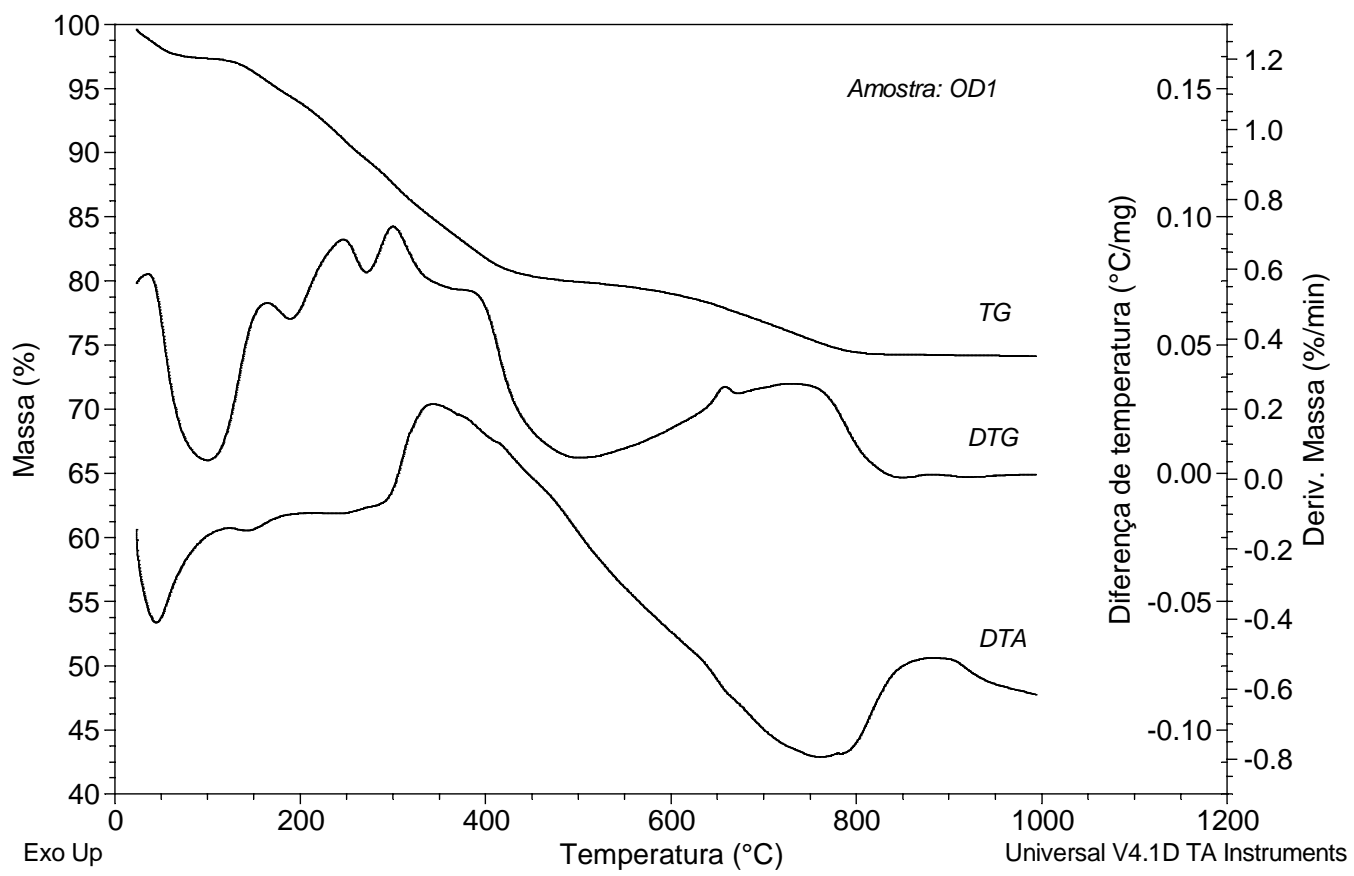

Figura 6.3.4 - Curvas TG, DTG e DTA da amostra D tratada com o sal quaternário 1.

As Figuras 6.3.5, 6.3.6, 6.3.7 e 6.3.8, mostram as curvas TG, DTG e DTA das argilas $A, B, C$ e $D$ tratadas com o sal quaternário 2 .

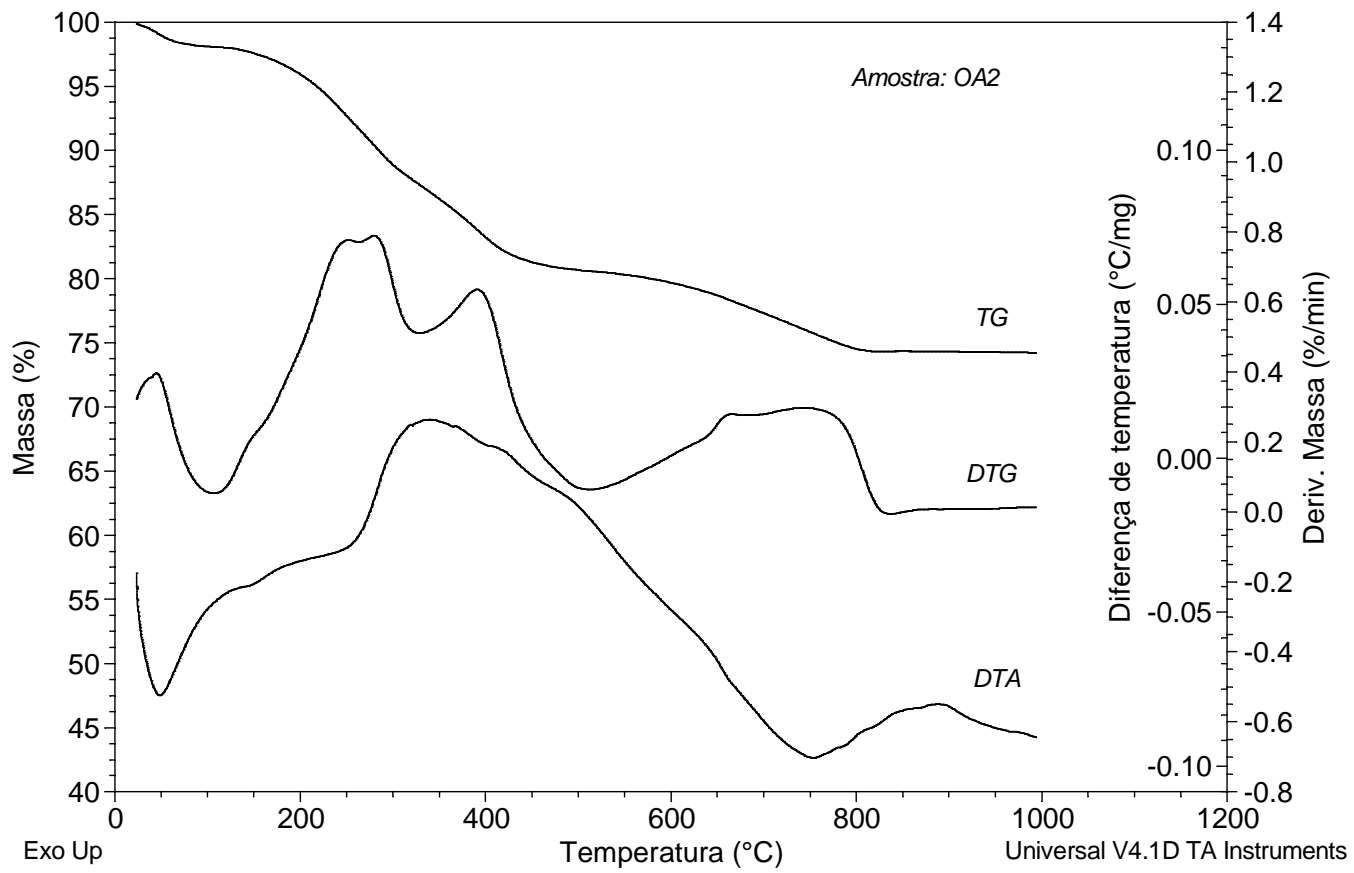

Figura 6.3.5 - Curvas TG, DTG e DTA da amostra A tratada com o sal quaternário 2. 


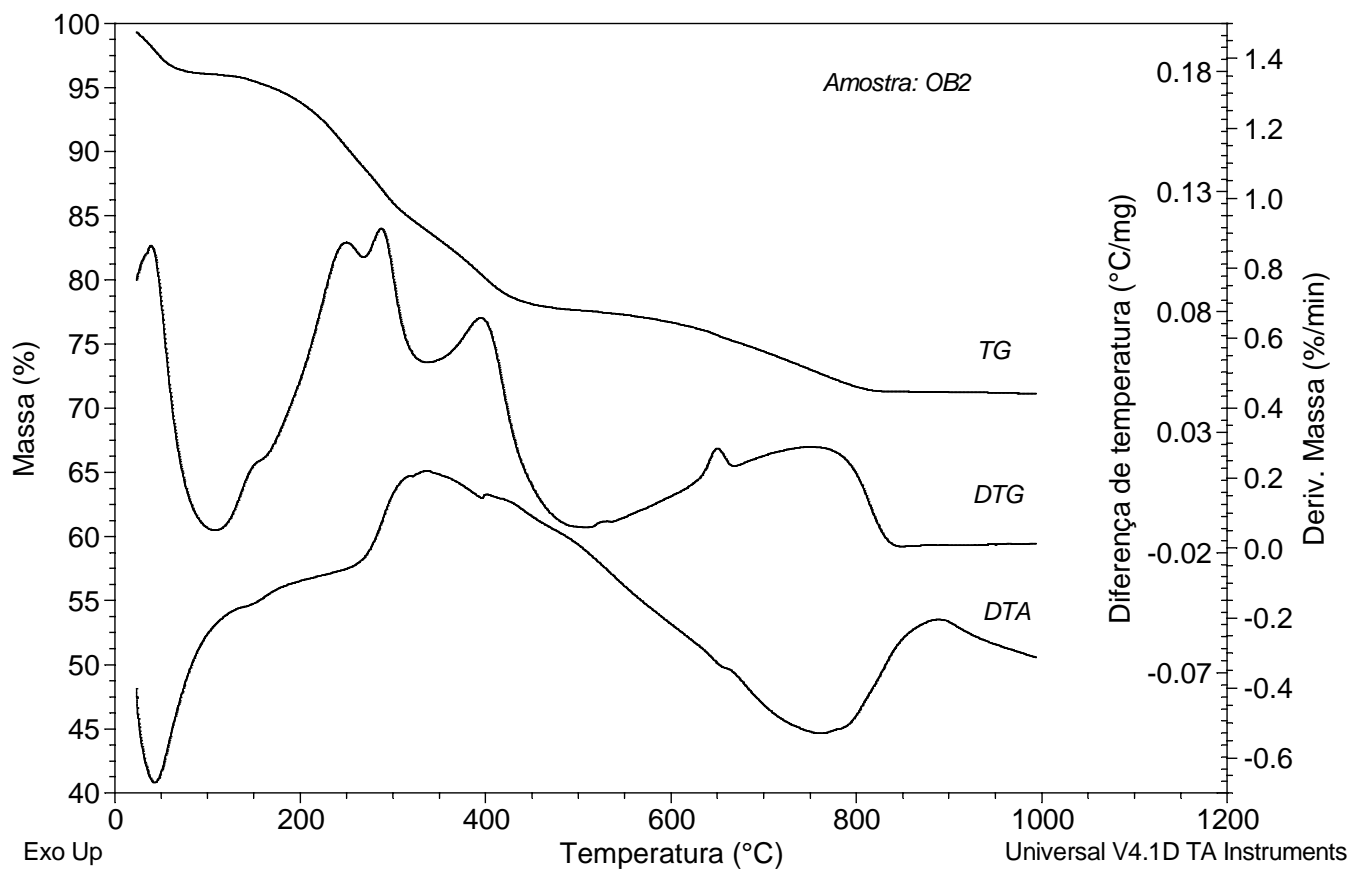

Figura 6.3.6 - Curvas TG, DTG e DTA da amostra B tratada com o sal quaternário 2.

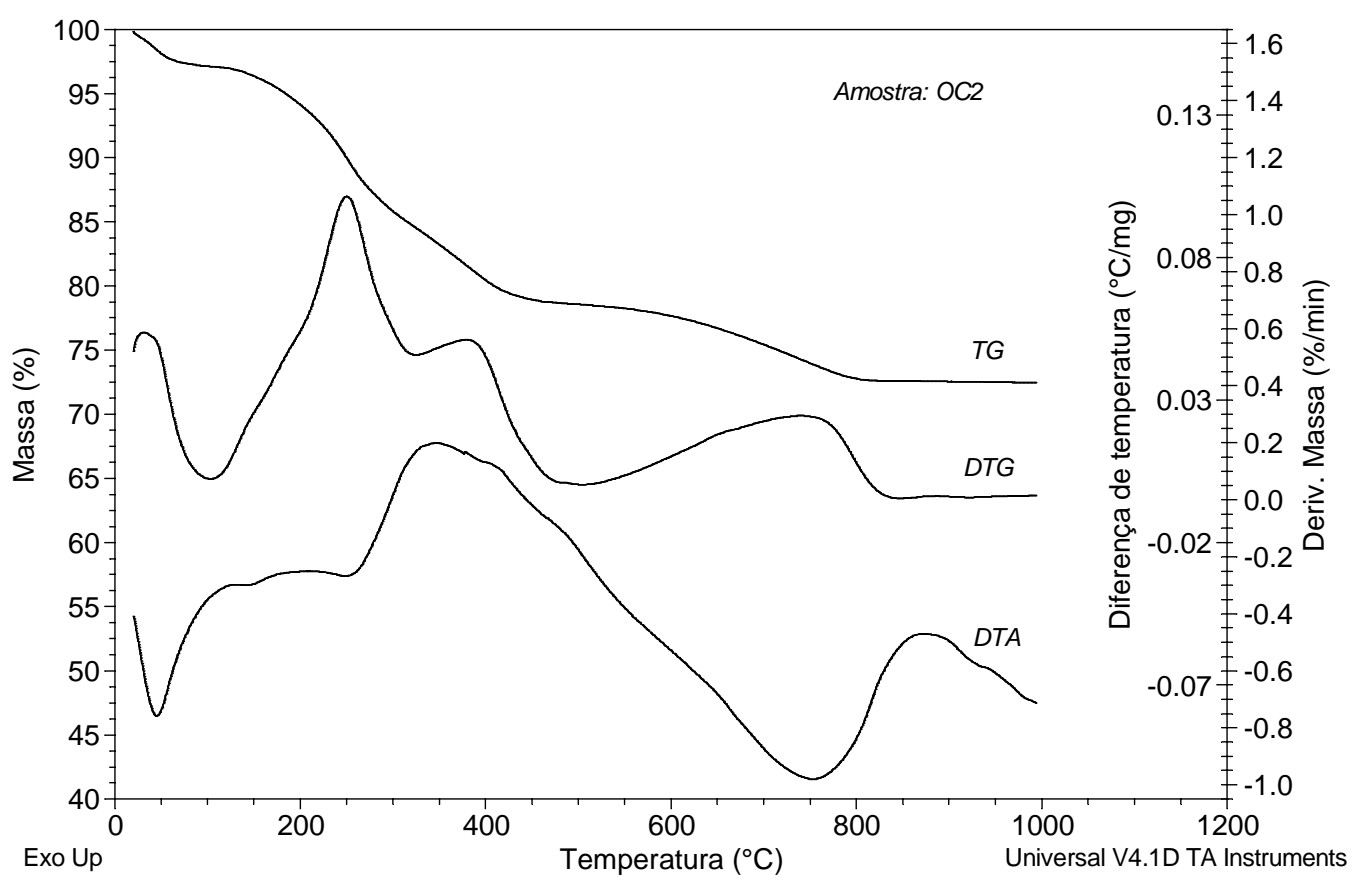

Figura 6.3.7 - Curvas TG, DTG e DTA da amostra C tratada com o sal quaternário 2. 


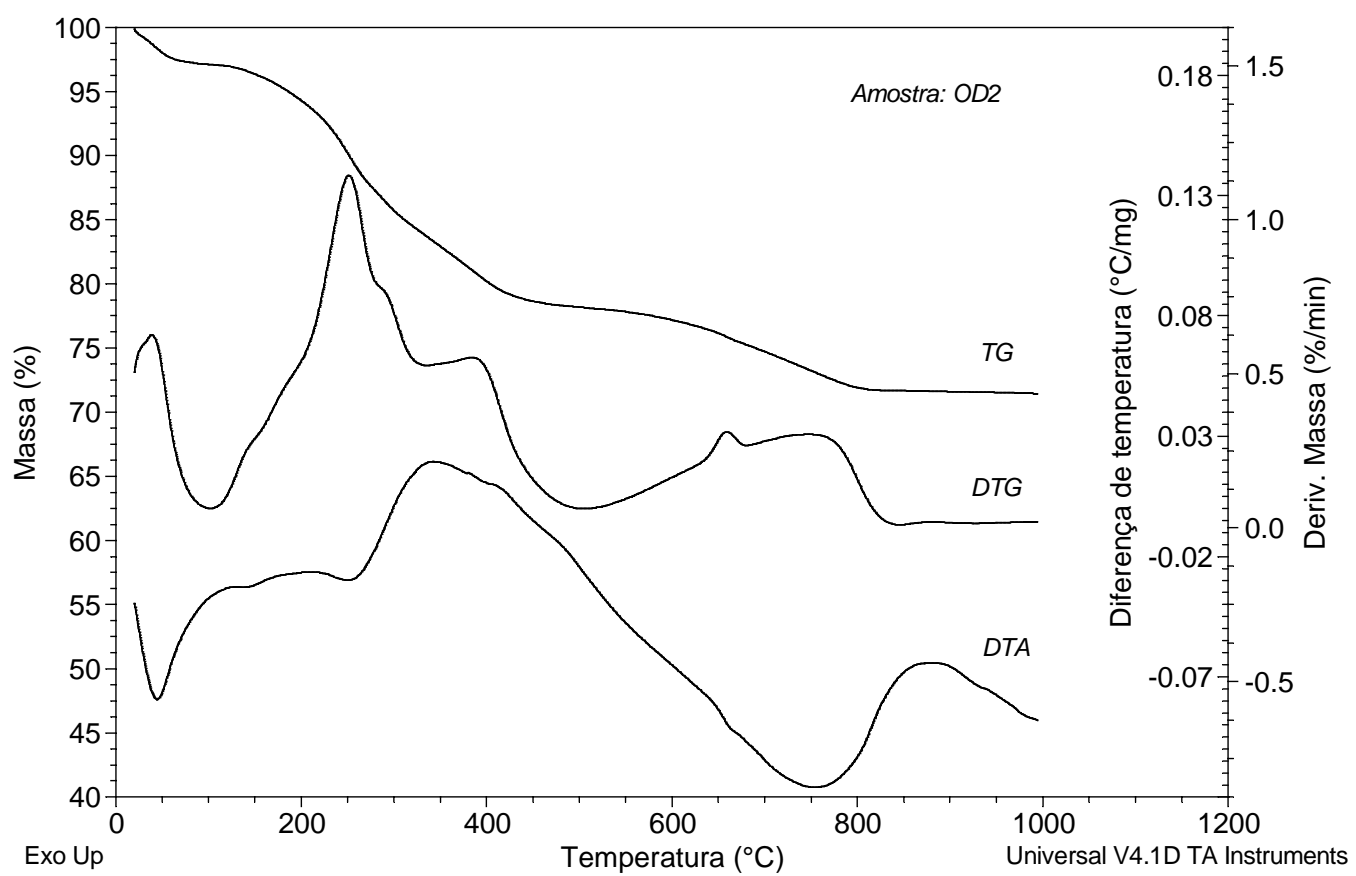

Figura 6.3.8 - Curvas TG, DTG e DTA da amostra D tratada com o sal quaternário 2.

As Figuras 6.3.9, 6.3.10, 6.3.11 e 6.3.12, mostram as curvas TG, DTG e DTA das argilas $A, B, C$ e $D$ tratadas com o sal quaternário 3 .

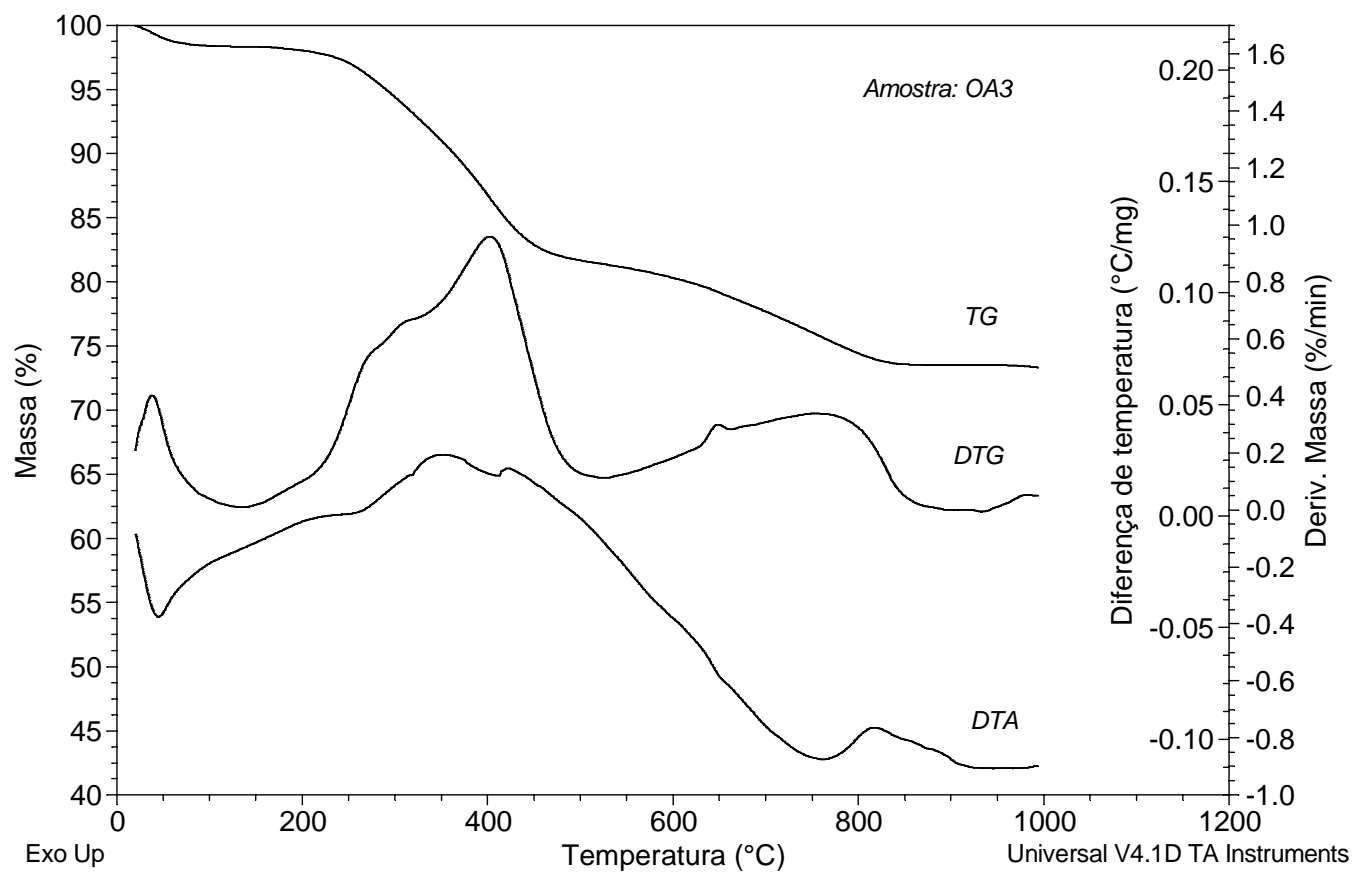

Figura 6.3.9 - Curvas TG, DTG e DTA da amostra A tratada com o sal quaternário 3. 


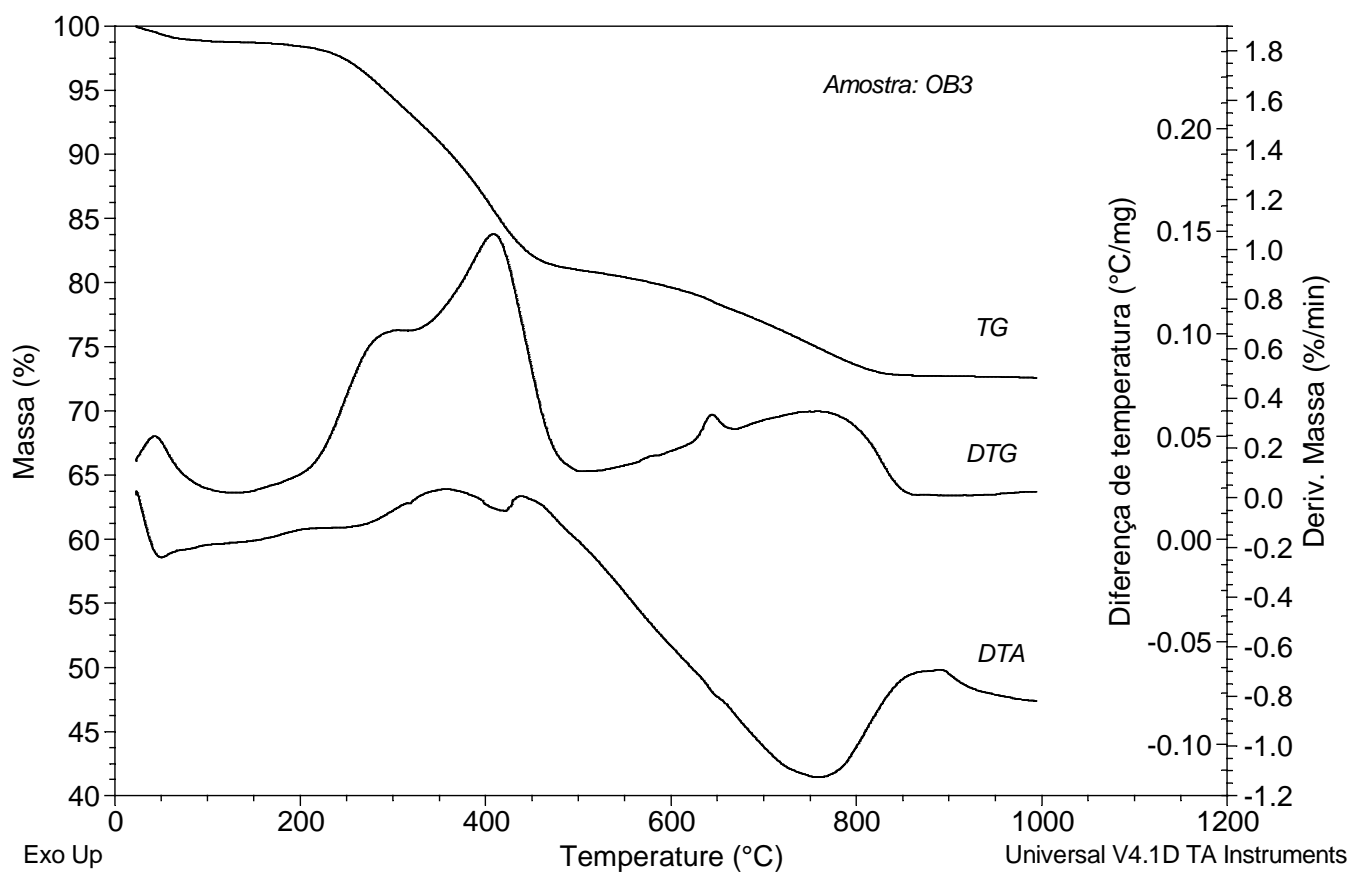

Figura 6.3.10 - Curvas TG, DTG e DTA da amostra B tratada com o sal quaternário 3.

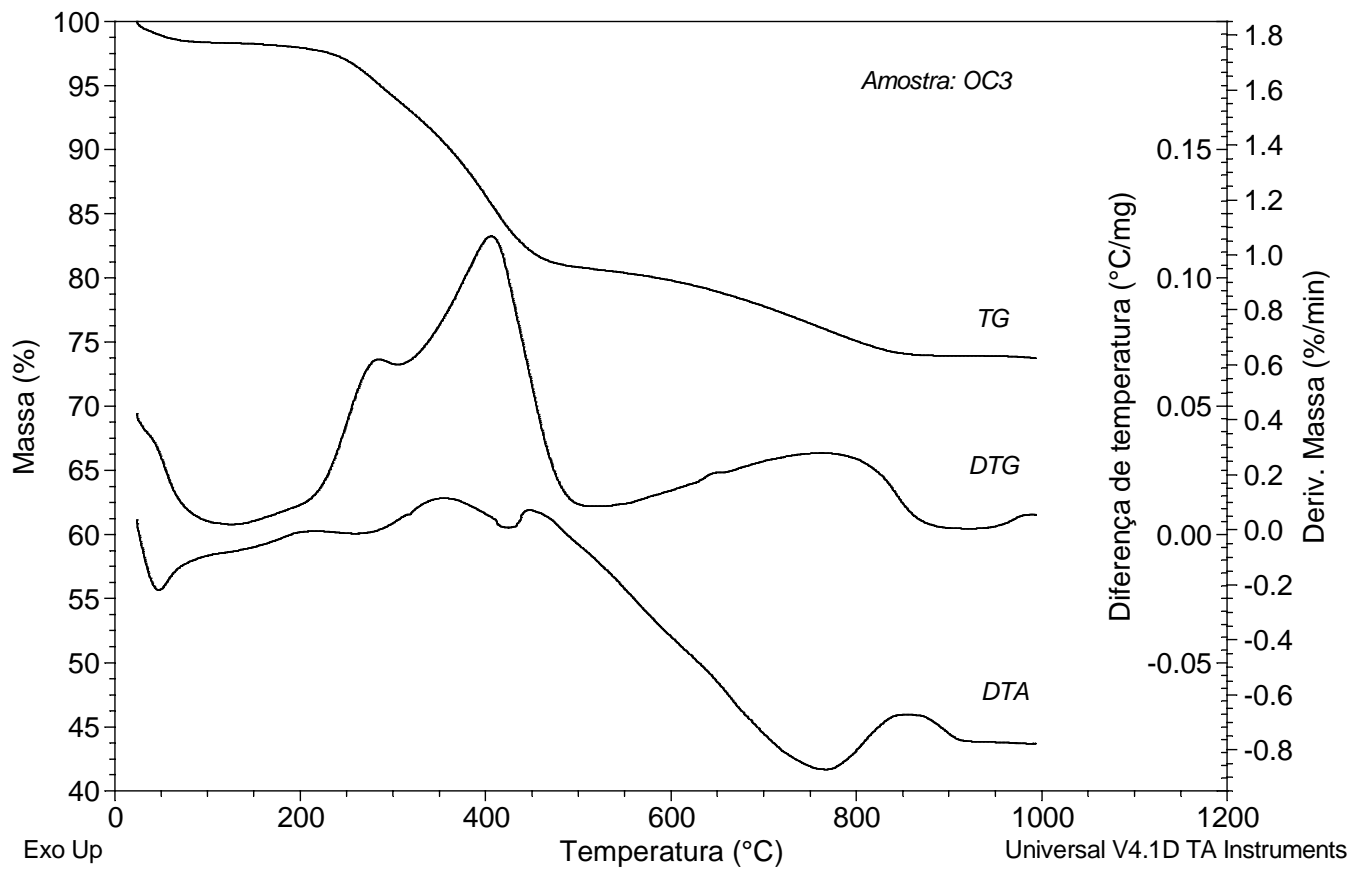

Figura 6.3.11 - Curvas TG, DTG e DTA da amostra C tratada com o sal quaternário 3. 


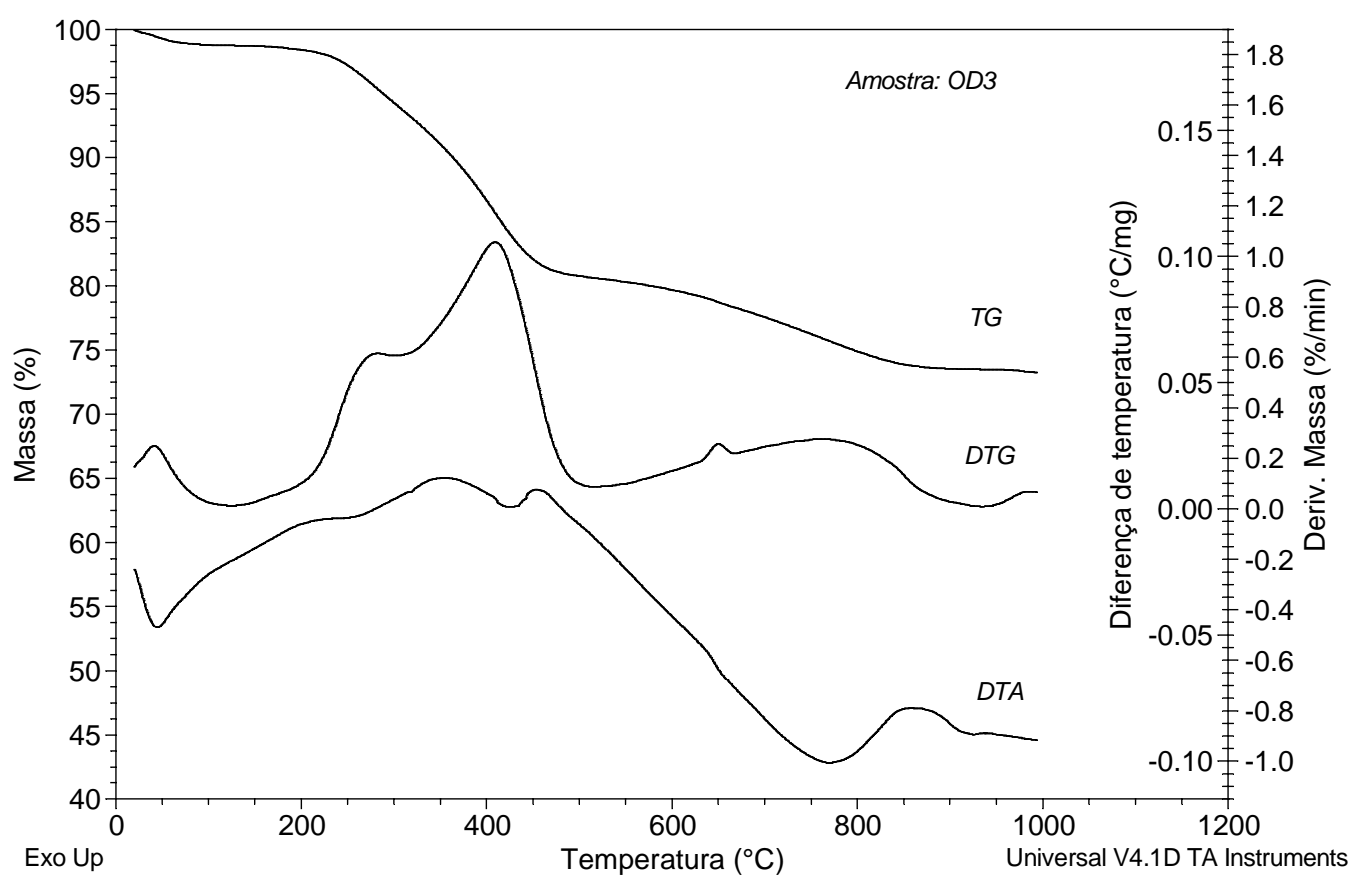

Figura 6.3.12 - Curvas TG, DTG e DTA da amostra D tratada com o sal quaternário 3.

$\mathrm{Na}$ Tabela 6.3.1 estão apresentados os valores de perda de massa, os quais variaram entre $25,5 \%$ e $28,7 \%$, o que indica (calculando-se as perdas de massa das argilas de partida e as quantidades de sal adicionadas) uma retenção maior a 70\% dos cátions orgânicos na preparação das argilas organofílicas. Caso a lavagem à qual foram submetidas no processamento tivesse retirado de forma expressiva a matéria orgânica os valores obtidos de perda de massa seriam substancialmente menores, isto é, próximos aos das argilas de partida.

Analisando-se as curvas de DTG ou de DTA ou ambas, observa-se, para as diversas argilas organofílicas obtidas, uma fase inicial de perda de umidade até aproximadamente $200^{\circ} \mathrm{C}$. A perda de matéria orgânica (eventos exotérmicos nas curvas de DTA), aproximadamente entre $200^{\circ} \mathrm{C}$ e $400^{\circ} \mathrm{C}$, é apresentada geralmente por mais de um pico, o que indica possivelmente que as cadeias dos sais quaternários de amônio se posicionaram em mais de uma posição preferencial em relação à superfície dos argilominerais. A perda de hidroxilas e possível pico exotérmico de recristalizações a altas temperaturas aparecem na faixa entre $400^{\circ} \mathrm{C}$ e $900^{\circ} \mathrm{C}$, sendo as interpretações difíceis de efetuar dada a queda das linhas de base nos ensaios de DTA [DWECK; BÜCHLER; CARTLEDGE, 2001]. 
Tabela 6.3.1 - Perdas de massa total das argilas organofílicas A, B, C e D obtidas com os sais quaternários 1,2 e 3 .

\begin{tabular}{|c|c|}
\hline Amostra & $\begin{array}{c}\text { Perda de massa total } \\
\text { (\%) }\end{array}$ \\
\hline \multicolumn{2}{|c|}{ Obtidas com sal 1 } \\
\hline A & 27,9 \\
B & 26,5 \\
C & 25,5 \\
D & 25,9 \\
\hline Obtidas com sal 2 \\
\hline A & 25,8 \\
B & 28,7 \\
C & 27,5 \\
D & 28,5 \\
\hline Obtidas com sal 3 \\
\hline A & 26,7 \\
B & 27,4 \\
C & 26,3 \\
D & 26,7 \\
\hline
\end{tabular}

\subsection{Microscopia Eletrônica de Varredura (MEV)}

Com o intuito de verificar a morfologia das amostras, obtiveram-se micrografias eletrônicas de varredura, que estão apresentadas nas Figuras 6.4.1 e 6.4.2, devido a problemas operacionais, unicamente foram obtidas micrografias para as argilas preparadas com os sais 1 e 2 . 

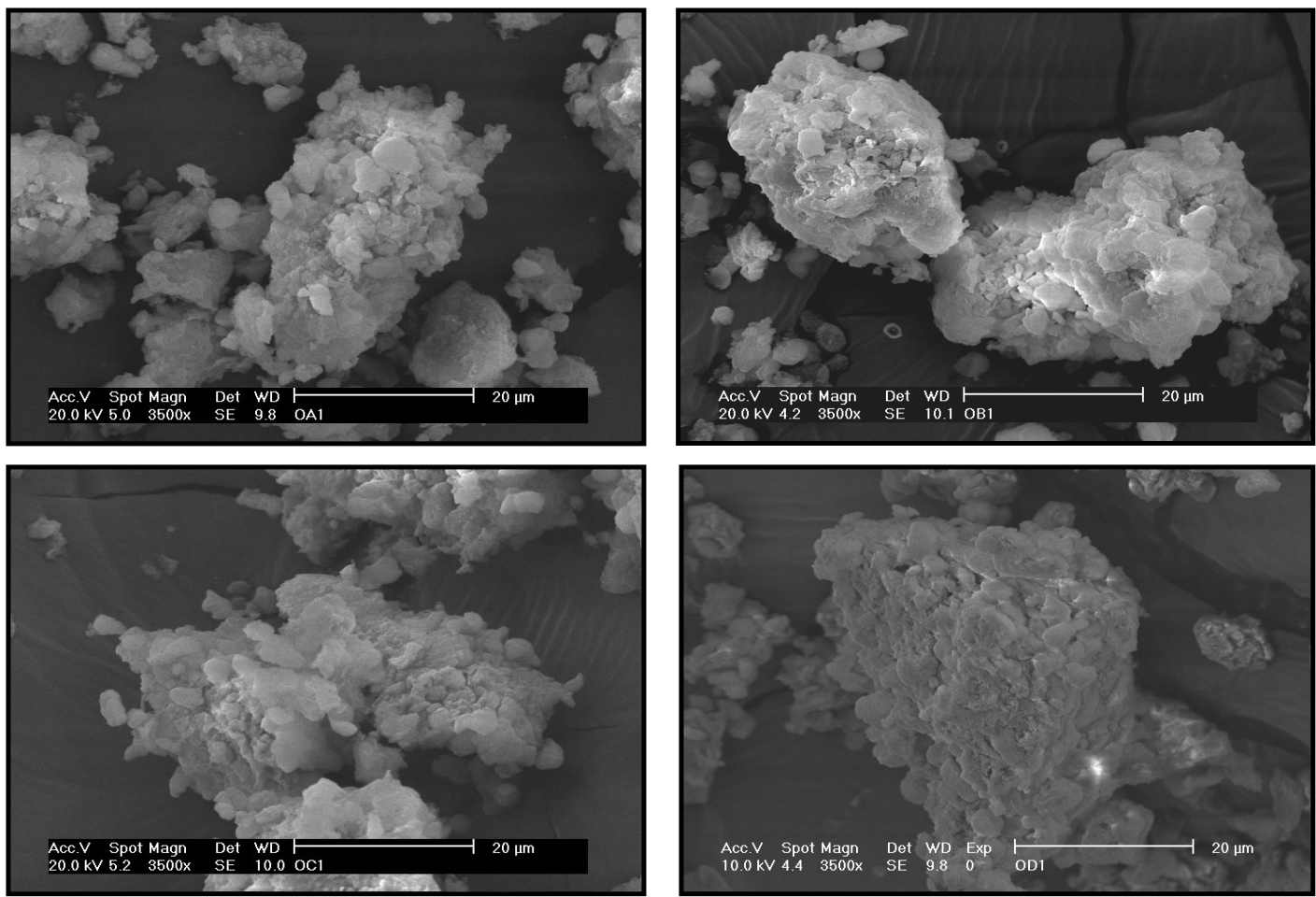

Figura 6.4.1 - Micrografias das amostras A, B, C e D, obtidas com sal quaternário 1.
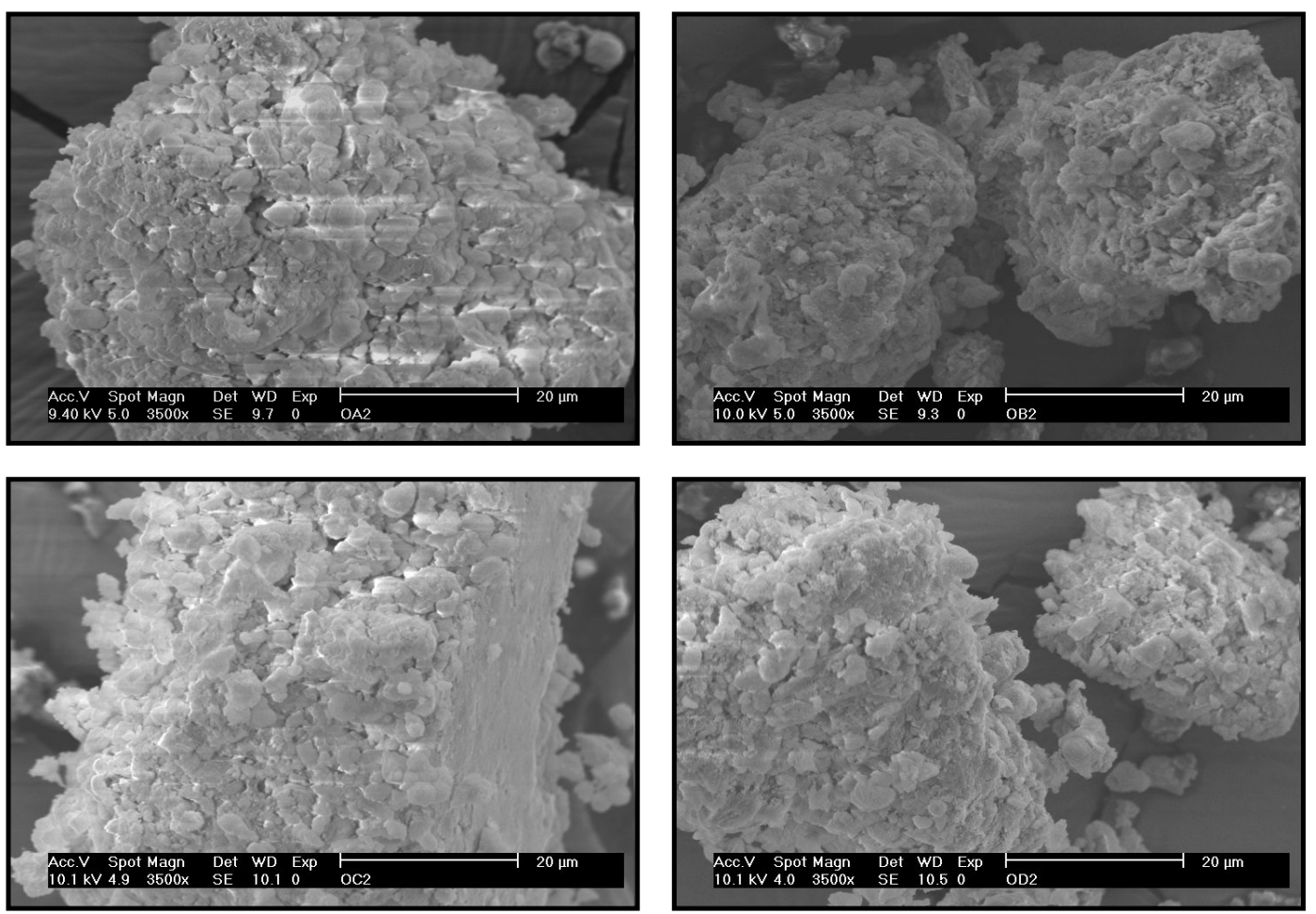

Figura 6.4.2 - Micrografias das amostras A, B, C e D, obtidas com sal quaternário 2. 
As argilas organofílicas obtidas a partir do sal 1 apresentam partículas elementares lamelares com diâmetro de aproximadamente 1 micrometro e dispostas umas sobre as outras, formando aglomerados com dimensões entre, aproximadamente, 20 e 30 micrometros. As obtidas a partir do sal 2 também apresentam partículas elementares com diâmetros da ordem de 1 micrometro e aglomeradas em partículas mas sendo estas partículas maiores que as obtidas com o sal 1 e tendo diâmetros aproximadamente entre 45 e 70 micrometros. As partículas observadas nas amostras preparadas com o sal 2 quando comparadas com as obtidas a partir do sal 1, além de maiores, apresentam um aspecto mais compacto e menos poroso.

\subsection{Inchamento de Foster (IF)}

A metodologia do teste de inchamento está descrita no item 3.3.2.2. De acordo com Valenzuela Díaz [1994] e devido aos diversos trabalhos que vêm sendo efetuados no Laboratório de Matérias-Primas Particuladas e Sólidos Não Metálicos da Escola Politécnica da Universidade de São Paulo (LMPSol/EPUSP) [PEREIRA et al. 2004; PEREIRA; RODRIGUES; VALENZUELA DIAZ, 2007, RAMOS VIANNA, 2005; PEREIRA et al., 2005, VIEIRA JOSÉ et al., 2002, BOTELHO et al., 2007, PEREIRA, 2003], foram adotas as seguintes considerações (Tabela 6.5.1) para o teste de inchamento de Foster:

Tabela 6.5.1 - Considerações adotadas no LMPSol para o teste de inchamento de Foster.

\begin{tabular}{cc}
\hline Inchamento & Faixa \\
\hline Não-inchamento & Igual ou inferior a $2 \mathrm{~mL} / \mathrm{g}$ \\
Baixo & 3 a $5 \mathrm{~mL} / \mathrm{g}$ \\
Médio & 6 a $8 \mathrm{~mL} / \mathrm{g}$ \\
Alto & Acima de $8 \mathrm{~mL} / \mathrm{g}$ \\
\hline
\end{tabular}

As Figuras 6.5.1 e 6.5.2, apresentam os resultados do teste de inchamento de Foster, sem agitação e com agitação, respectivamente. 


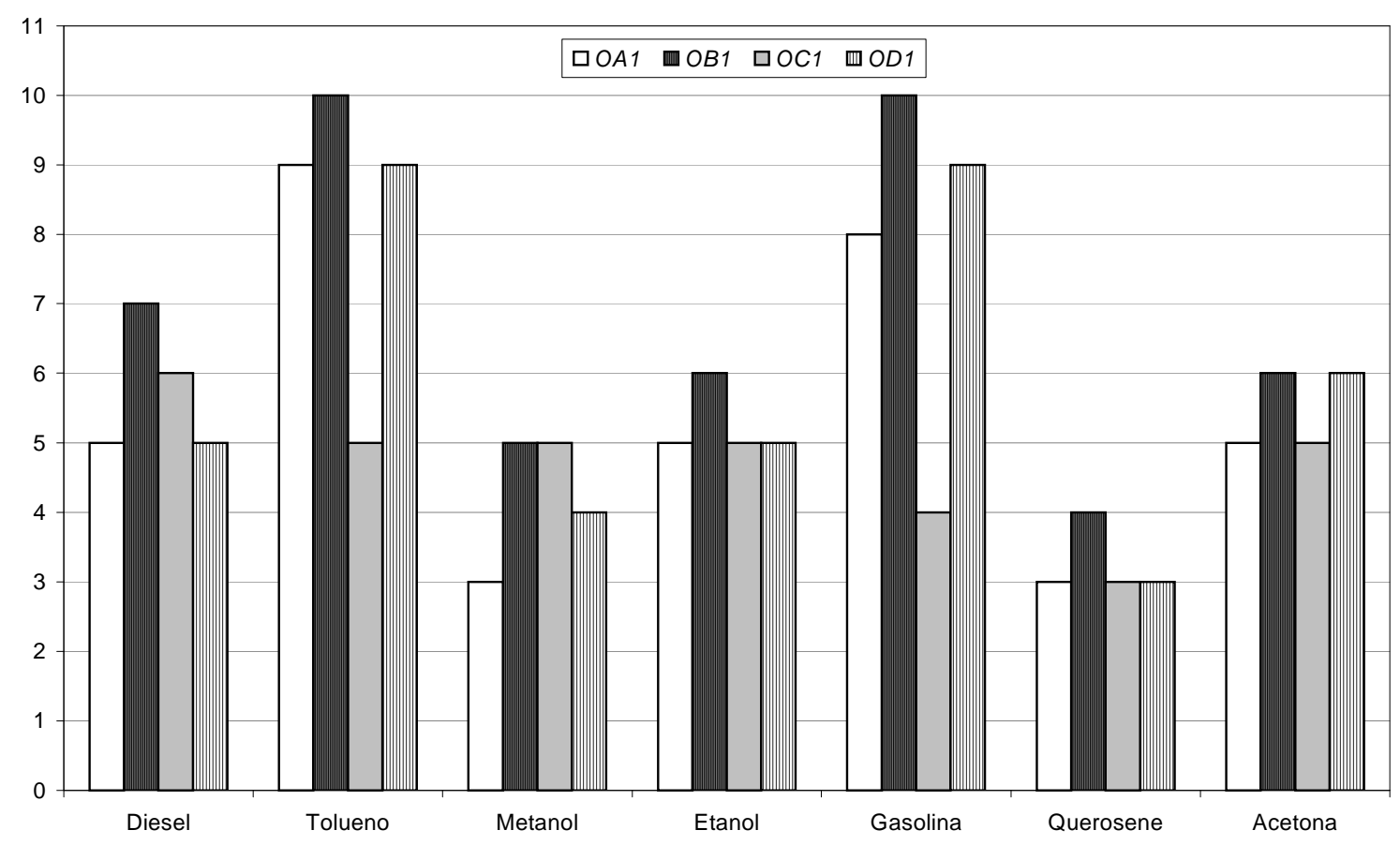

Figura 6.5.1 - Inchamento de Foster, sem agitação, das amostras A, B, C e D tratadas com o sal quaternário 1.

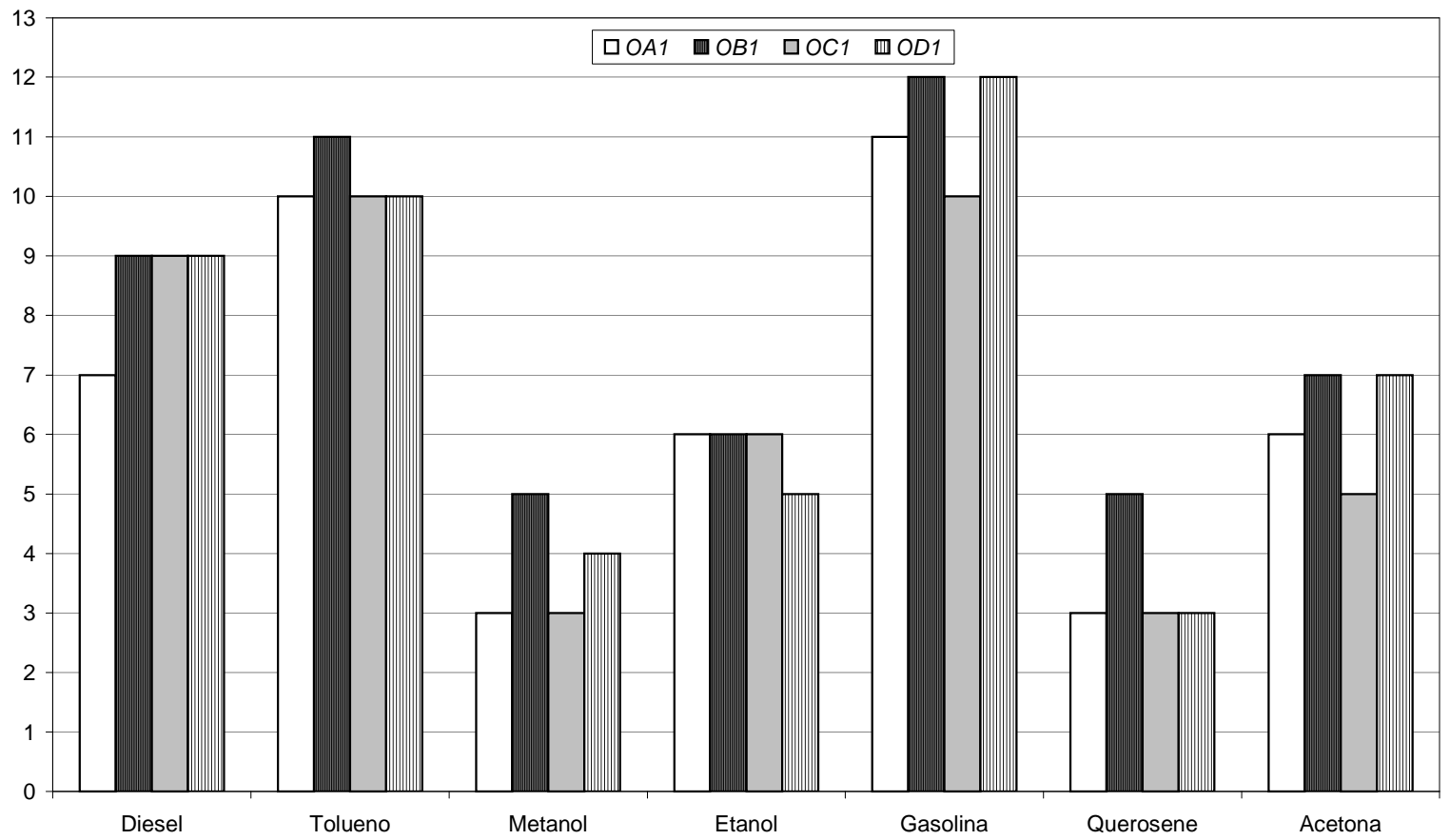

Figura 6.5.2 - Inchamento de Foster, com agitação, das amostras A, B, C e D tratadas com o sal quaternário 1. 
Observam-se, pelos resultados apresentados nas Figuras 6.5.1 e 6.5.2, no teste de inchamento das amostras preparadas com o sal quaternário 1 , em relação a Tabela 6.5.1, que:

1) A argila A apresentou comportamento:

a) baixo inchamento nos solventes: diesel (sem agitação), metanol (sem e com agitação), etanol (sem e com agitação), querosene (sem e com agitação) e acetona (sem e com agitação).

b) médio inchamento em gasolina (sem e com agitação) e diesel (com agitação).

c) alto inchamento em tolueno (sem e com agitação).

2) A amostra B apresentou o seguinte:

a) baixo inchamento, sem e com agitação, nos solventes: metanol e querosene.

b) médio inchamento, sem e com agitação, em diesel, etanol e acetona.

c) alto inchamento, sem e com agitação, em tolueno e gasolina.

3) A amostra $C$ apresentou-se da seguinte maneira:

a) baixo inchamento nos solventes: tolueno, etanol e gasolina (sem agitação); metanol e acetona (sem e com agitação) e querosene (com agitação).

b) médio inchamento em diesel (sem agitação) e etanol (com agitação).

c) alto inchamento em diesel, gasolina e tolueno (com agitação) e querosene (sem agitação).

4) A amostra D apresentou os seguintes inchamentos:

a) baixo inchamento nos solventes: etanol, metanol, querosene (sem e com agitação); diesel (sem agitação).

b) médio inchamento em acetona (sem e com agitação).

c) alto inchamento em gasolina e tolueno (sem e com agitação) e diesel (com agitação).

Os resultados do teste de inchamento de Foster, sem agitação e com agitação, estão apresentados na Figuras 6.5.3 e 6.5.4. 


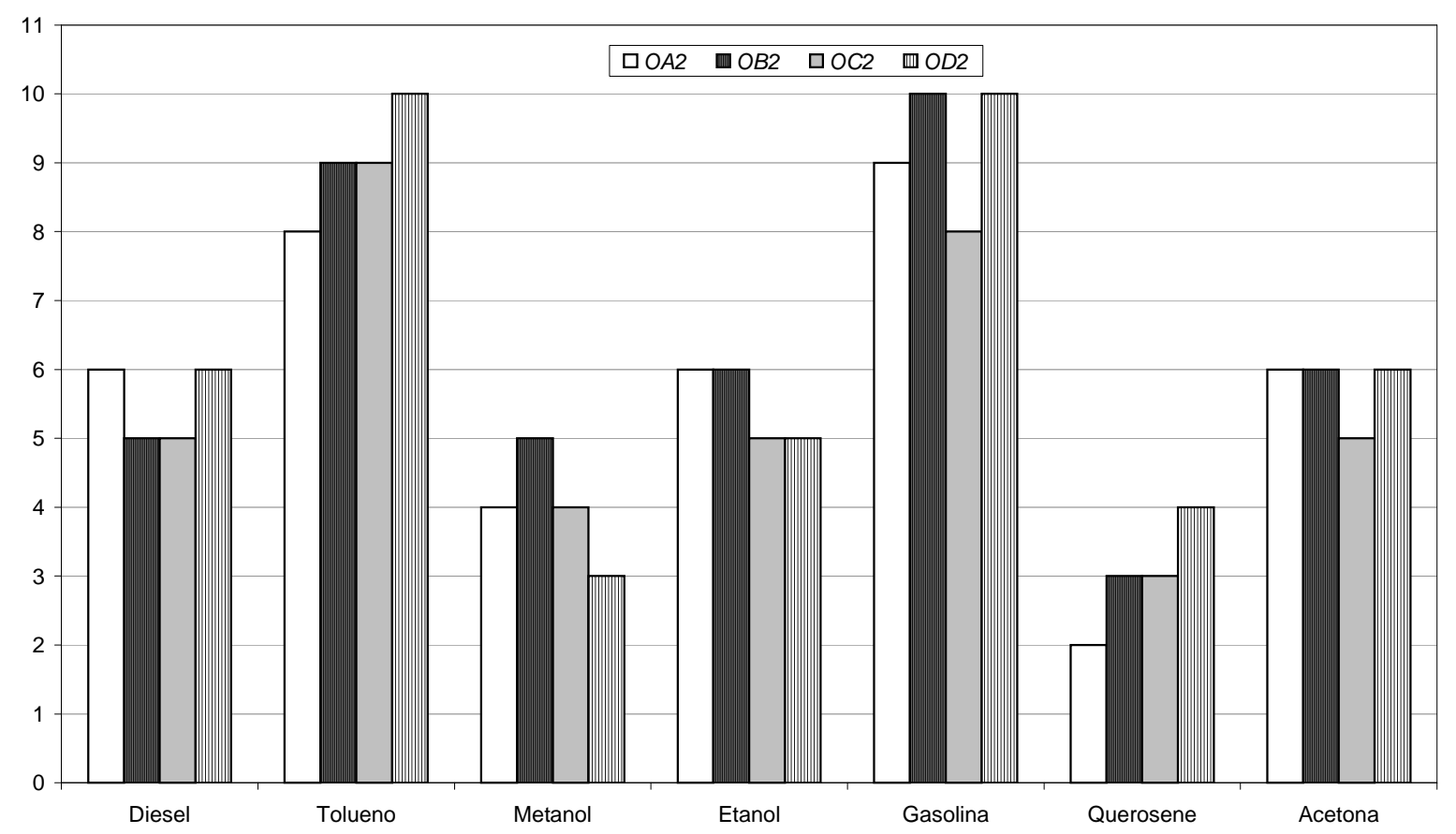

Figura 6.5.3 - Inchamento de Foster, sem agitação, das amostras A, B, C e D tratadas com o sal quaternário 2.

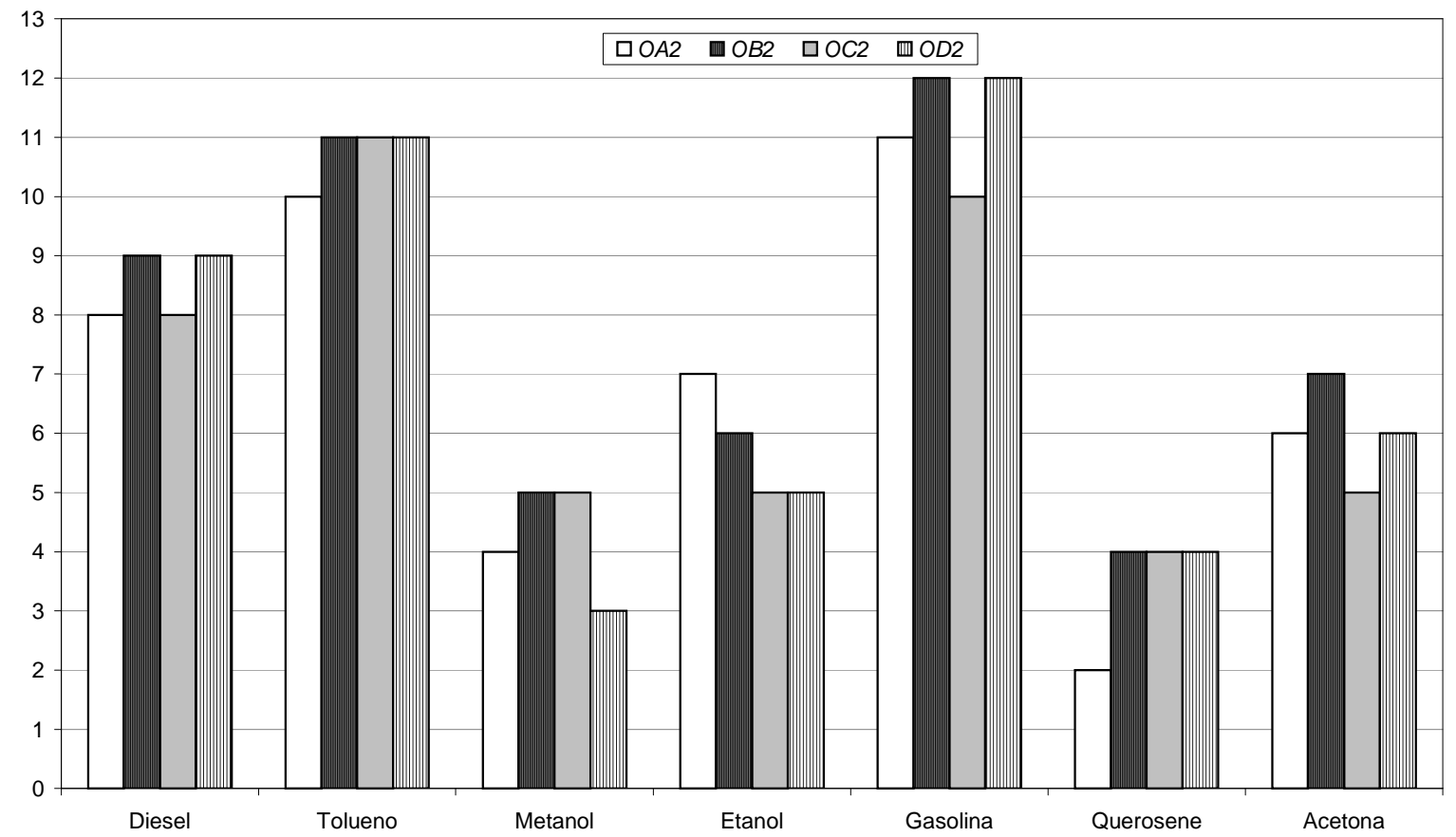

Figura 6.5.4 - Inchamento de Foster, com agitação, das amostras A, B, C e D tratadas com o sal quaternário 2. 
A partir destes resultados de inchamento em solventes orgânicos das amostras preparadas com o sal quaternário 2, em relação a Tabela 6.5.1, observase que:

1) $O$ comportamento da argila $A$ foi:

a) não-inchamento em querosene (sem e com agitação).

b) baixo inchamento nos solventes: metanol (sem e com agitação).

c) médio inchamento em diesel (sem e com agitação), tolueno (sem agitação), etanol (sem e com agitação) e acetona (sem e com agitação).

d) alto inchamento em tolueno (com agitação), gasolina (sem e com agitação).

2) Em relação a amostra $B$, foi apresentado os seguintes comportamentos:

a) baixo inchamento nos solventes: diesel (sem agitação), metanol (sem e com agitação) e querosene (sem e com agitação).

b) médio inchamento, sem e com agitação, em etanol e acetona.

c) alto inchamento, sem e com agitação, em tolueno e gasolina e diesel (com agitação).

3) Os resultados para amostra $C$ foram:

a) baixo inchamento, sem e com agitação, nos solventes: metanol, etanol e querosene e diesel (sem agitação).

b) médio inchamento em diesel (com agitação), gasolina (sem agitação) e acetona (sem e com agitação).

c) alto inchamento em gasolina (com agitação) e tolueno (sem e com agitação).

4) Os inchamentos apresentados pela amostra $D$ foram os seguintes:

a) baixo inchamento nos solventes: metanol, etanol e querosene (sem e com agitação).

b) médio inchamento em acetona (sem e com agitação) e diesel (sem agitação).

c) alto inchamento em gasolina e tolueno (sem e com agitação) e diesel (com agitação). 
O teste de inchamento das amostras preparadas com 0 sal quaternário 3 estão apresentados na Figuras 6.5.5 e 6.5.6.

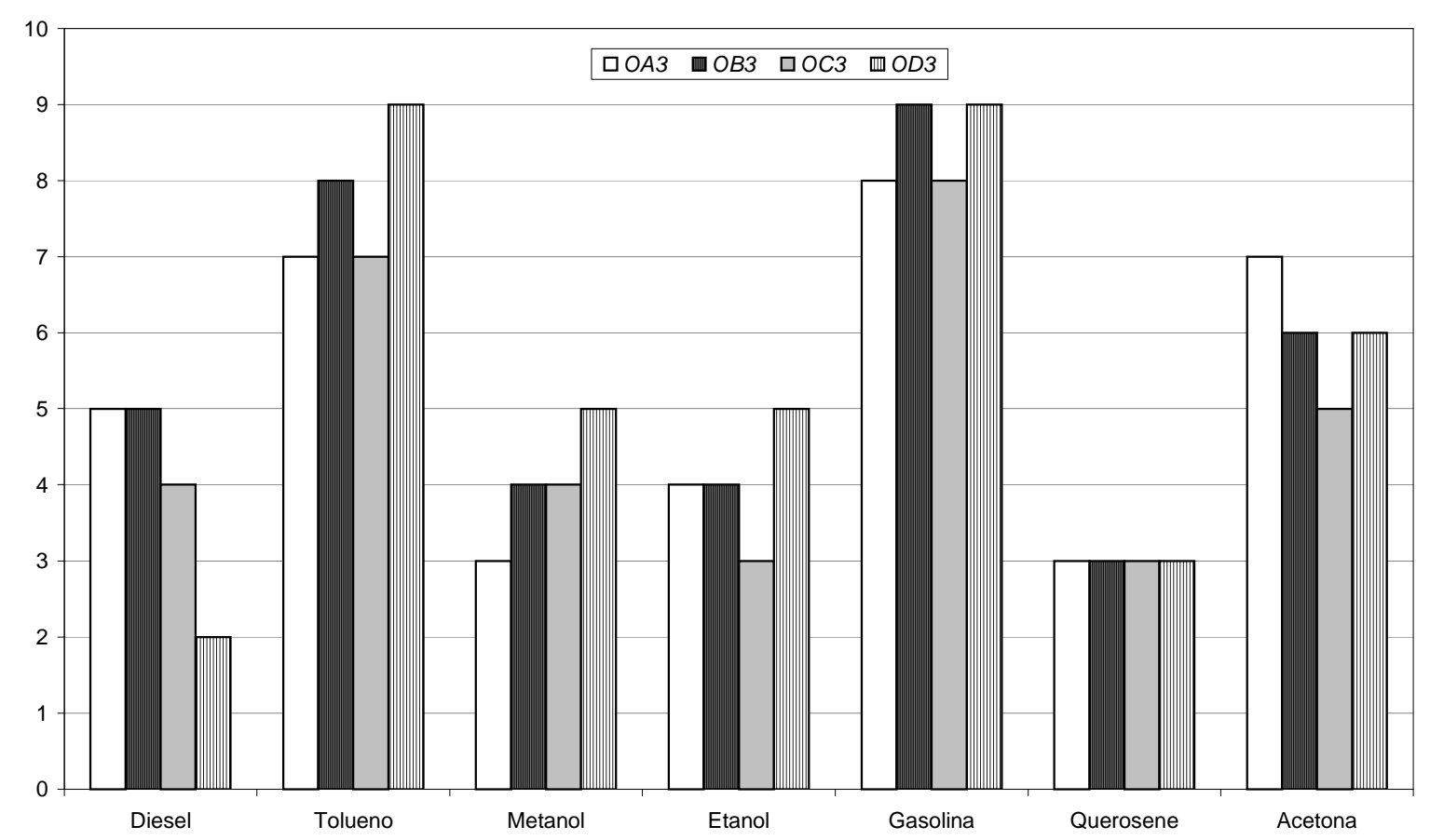

Figura 6.5.5 - Inchamento de Foster, sem agitação, das amostras A, B, C e D tratadas com o sal quaternário 3.

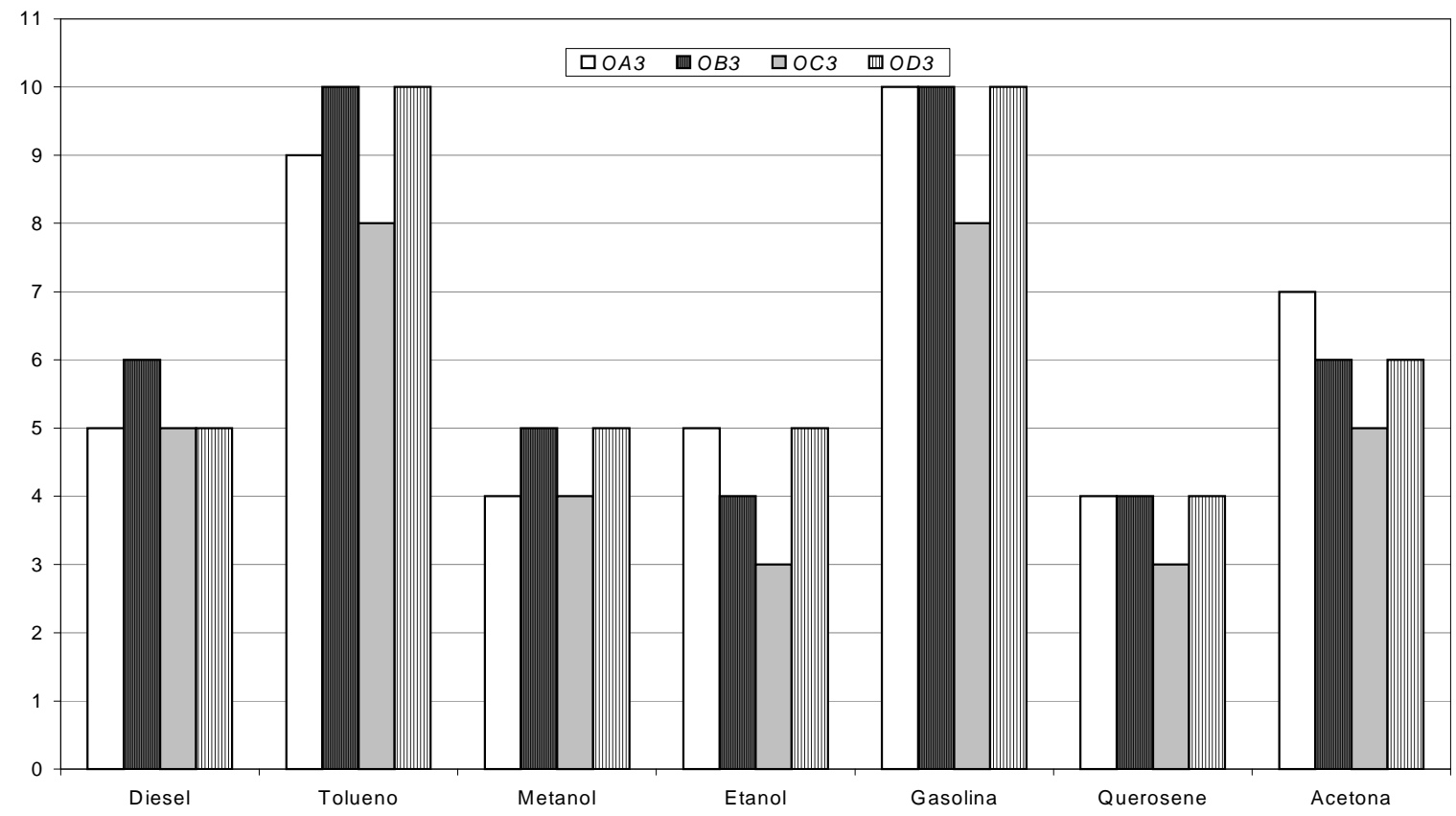

Figura 6.5.6 - Inchamento de Foster, com agitação, das amostras A, B, C e D tratadas com o sal quaternário 3. 
A partir dos resultados, de inchamento, apresentados pelas amostras obtidas com o sal quaternário 3, em relação a Tabela 6.5.1, temos que:

1) A argila A obteve:

a) baixo inchamento em: diesel, metanol, etanol e querosene (sem e com agitação).

b) médio inchamento em tolueno e gasolina (sem agitação) e acetona (sem e com agitação).

c) alto inchamento em gasolina e tolueno (com agitação).

2) A amostra B apresentou os seguintes comportamentos:

a) baixo inchamento nos solventes: metanol, etanol e querosene (sem e com agitação) e diesel (sem agitação).

b) médio inchamento, sem e com agitação, em acetona, diesel (com agitação) e tolueno (sem agitação).

c) alto inchamento, sem e com agitação, em gasolina e tolueno (com agitação).

3) Para amostra C obteve-se:

a) baixo inchamento, sem e com agitação, nos solventes: diesel, metanol, etanol, querosene e acetona.

b) médio inchamento, sem e com agitação, nos solventes: tolueno e gasolina.

4) No caso da amostra $D$, temos os seguintes inchamentos:

a) não-inchamento em diesel (sem agitação).

b) baixo inchamento nos solventes: metanol, etanol e querosene (sem e com agitação) e diesel (com agitação).

c) médio inchamento em acetona (sem e com agitação).

d) alto inchamento em tolueno e gasolina (sem e com agitação).

De acordo com os resultados apresentados nas Figuras 6.5.3, 6.5.4 e 6.5.6, observamos que apenas 2 amostras não apresentaram inchamento, que foram: $A$, obtida com sal 2 no solvente querosene e a amostra $D$, obtida com o sal 3 no solvente diesel. 
Pelos resultados dos testes de inchamento em solventes, observa-se que unicamente com metanol não foram obtidas amostras com ao menos inchamentos médios. Com acetona e etanol algumas amostras obtiveram inchamentos médios. Com querosene a amostra OC1 obteve inchamento elevado e em diesel, tolueno e gasolina diversas das amostras preparadas apresentaram alto inchamento.

Segundo Gomes [1988], a adsorção ou interação depende da estrutura e propriedade do poluente assim como da natureza dos minerais argilosos e dos seus cátions de troca e pode processar-se de acordo com os seguintes mecanismos:

a) Adsorção preferencial dos cátions orgânicos aos cátions inorgânicos, por motivo das maiores dimensões e dos elevados pesos moleculares dos cátions orgânicos.

b) Protonação de compostos orgânicos, adsorvidos nas superfícies dos minerais argilosos, embora neutros ao $\mathrm{pH}$ ambiente.

c) Coordenação ou íon-dipolo que se verifica em compostos com N, S e O que têm pares de elétrons que podem ser cedidos a cátions de troca eletrofílicos, formando complexos nas superfícies dos minerais argilosos.

d) Ligação hidrogênio que pode atuar de três modos distintos: entre moléculas de água que solvatam cátions e grupos funcionais como o grupo carbonilo de certas moléculas orgânicas; entre grupos funcionais como o grupo amino e oxigênio situado em superfícies exteriores dos minerais argilosos ou entre duas moléculas de espécies orgânicas adsorvidas nos minerais argilosos.

Valenzuela Díaz [1994] utilizou em sua tese uma amostra de mesmo tipo das utilizadas nesta tese, denominada de Róseo Bofe. Ao compararmos os resultados obtidos pelo autor, verificamos que, com amostra de mesmo tipo que as utilizadas nesta tese, também apresentaram os melhores inchamentos em tolueno.

Pereira [2003] realizou estudo de obtenção de argilas organofílicas, em seus resultados de inchamento de Foster, utilizando o sal 1 desta tese, verificou que a amostra apresentou comportamento similar, ou seja, os maiores inchamentos foram para os solventes gasolina e tolueno e os mais baixos em metanol e etanol.

Botelho et al. [2007] preparou argilas organofílicas a partir de argila importada para obtenção de nanocompósitos poliméricos e realizou com estas amostras modificadas teste de inchamento de Foster em diversos solventes orgânicos, dentre estes solventes foi utilizado 0 tolueno. Seus resultados demonstraram comportamento similar aos obtidos neste trabalho de inchamento em tolueno. 
Gonzaga et al. [2007] preparou argila organofílica a partir de argila do tipo Bofe e método de preparação similar ao realizado nesta Tese e obteve altos valores de inchamento, de acordo com a Tabela 6.5.1, em gasolina.

Comportamento também semelhante com os obtidos nesta tese foi apresentado por Ramos Vianna [2005], que desenvolveu argilas organofílicas para remediação de áreas contaminadas, verificou nos testes de inchamento de Foster que os melhores resultados, independente do método de preparação utilizado, foram nos solventes: gasolina, tolueno, etilbenzeno e xilenos.

\subsection{Sorção}

Moléculas orgânicas são hidrofóbicas e, portanto, sem afinidade para as superfícies hidrofílicas dos minerais argilosos, mas o caráter hidrofílico dos minerais argilosos pode ser alterado para hidrofóbico e organofílico se os cátions inorgânicos trocáveis forem substituídos por cátions orgânicos. Tudo isto sugere que nos sistemas naturais, os complexos argila - moléculas orgânicas podem atuar como meios adsorventes para alguns compostos orgânicos poluentes [GOMES, 1988].

Os resultados de sorção das amostras A, B, C e D obtidas com os sais quaternários 1, 2 e 3, estão apresentados nas Figuras 6.6.1, 6.6.2 e 6.6.3, respectivamente. 


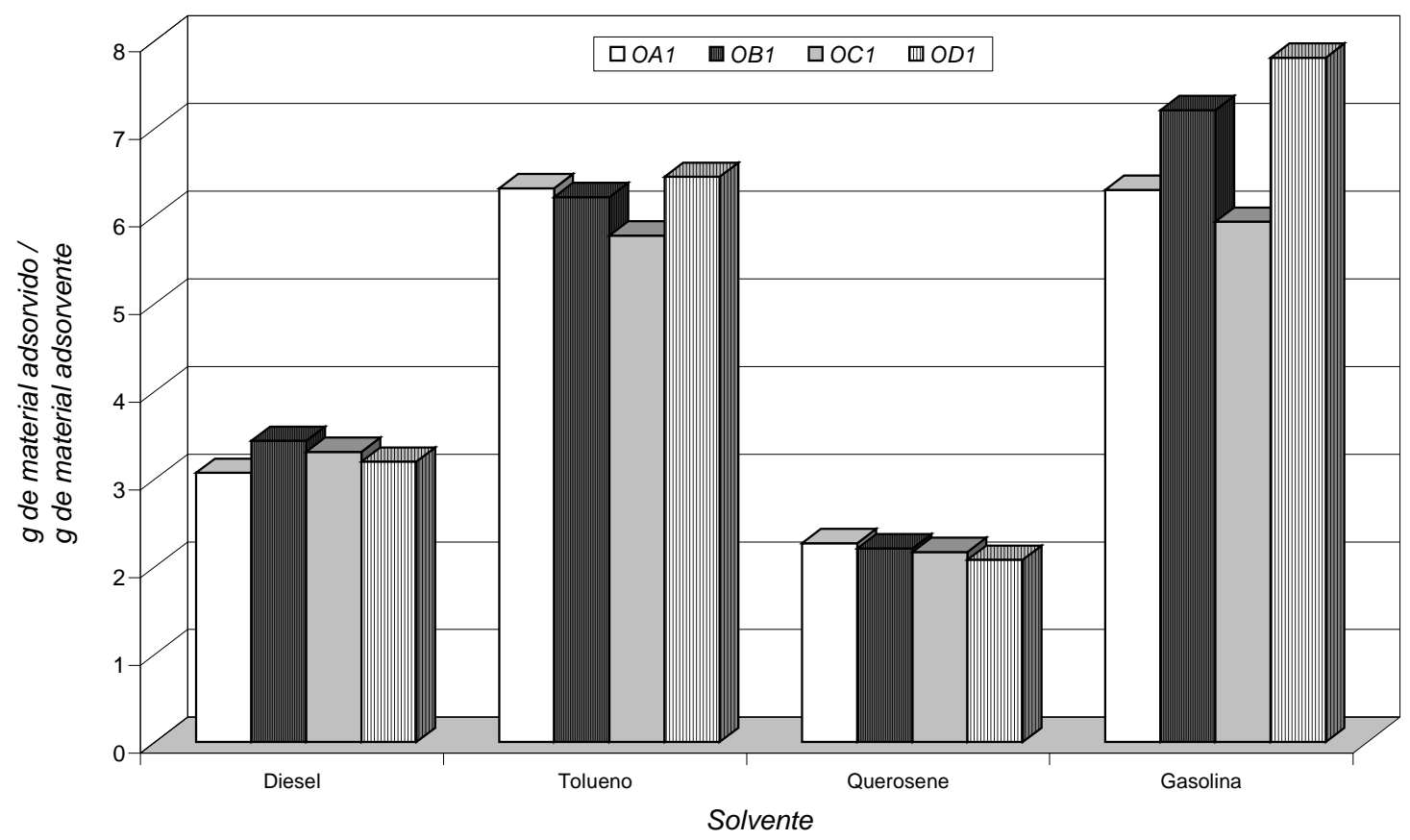

Figura 6.6.1 - Sorção das amostras A, B, C e D tratadas com o sal quaternário 1.

Com os resultados apresentados na Figura 6.6.1 para o teste de sorção das amostras preparadas com o sal 1, verifica-se:

1) Amostra A sorveu: querosene < diesel < tolueno < gasolina.

2) Amostra B sorveu: querosene < diesel < tolueno < gasolina.

3) Amostra $C$ sorveu: querosene $<$ diesel $<$ tolueno < gasolina.

4) Amostra D sorveu: querosene < diesel < tolueno < gasolina. 


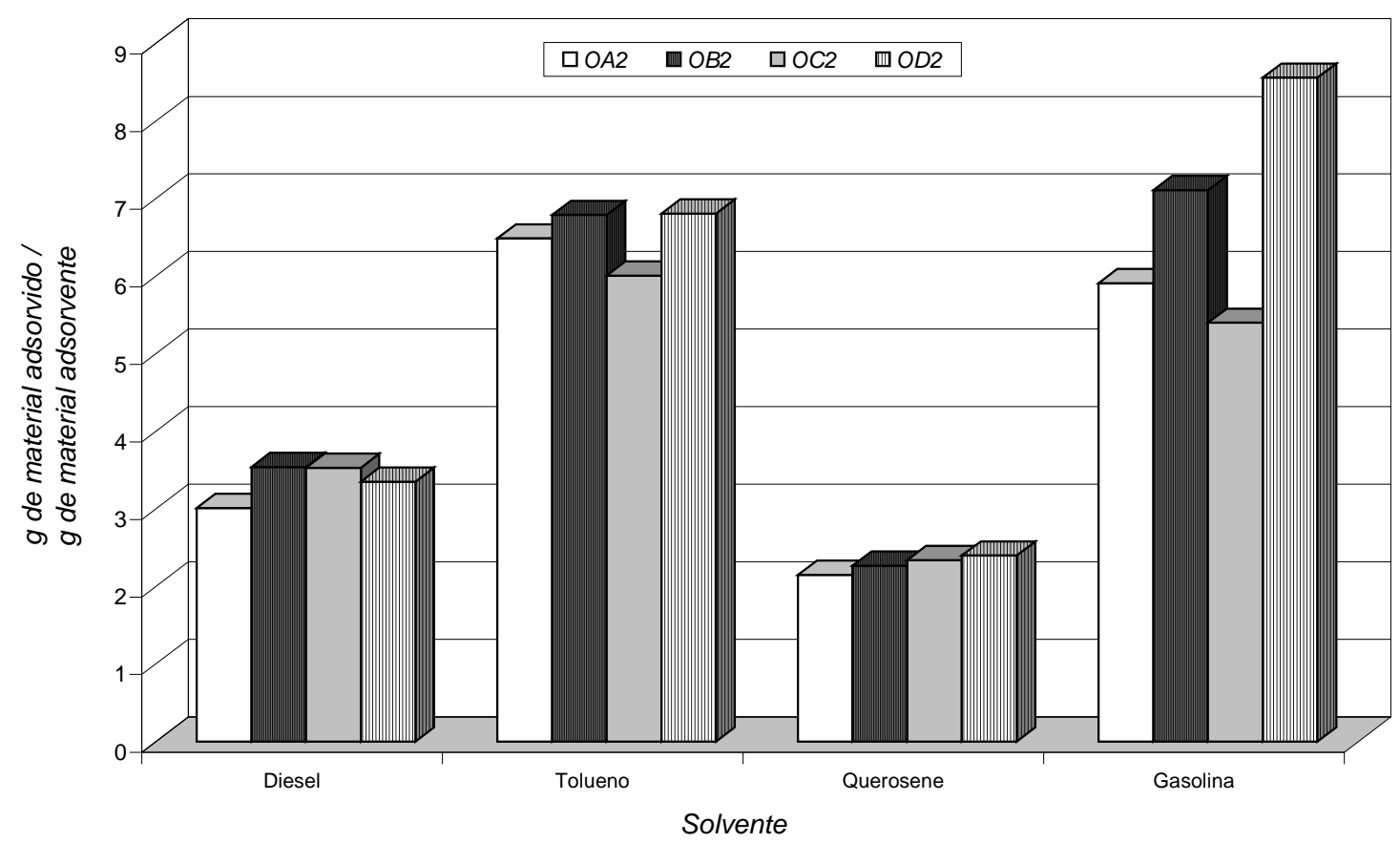

Figura 6.6.2 - Sorção das amostras A, B, C e D tratadas com o sal quaternário 2.

Os resultados apresentados na Figura 6.6.2 indicam que as amostras preparadas com o sal 2:

1) Amostra A sorveu: querosene < diesel < gasolina < tolueno.

2) Amostra B sorveu: querosene < diesel < tolueno < gasolina.

3) Amostra C sorveu: querosene < diesel < gasolina < tolueno.

4) Amostra D sorveu: querosene < diesel < tolueno < gasolina. 


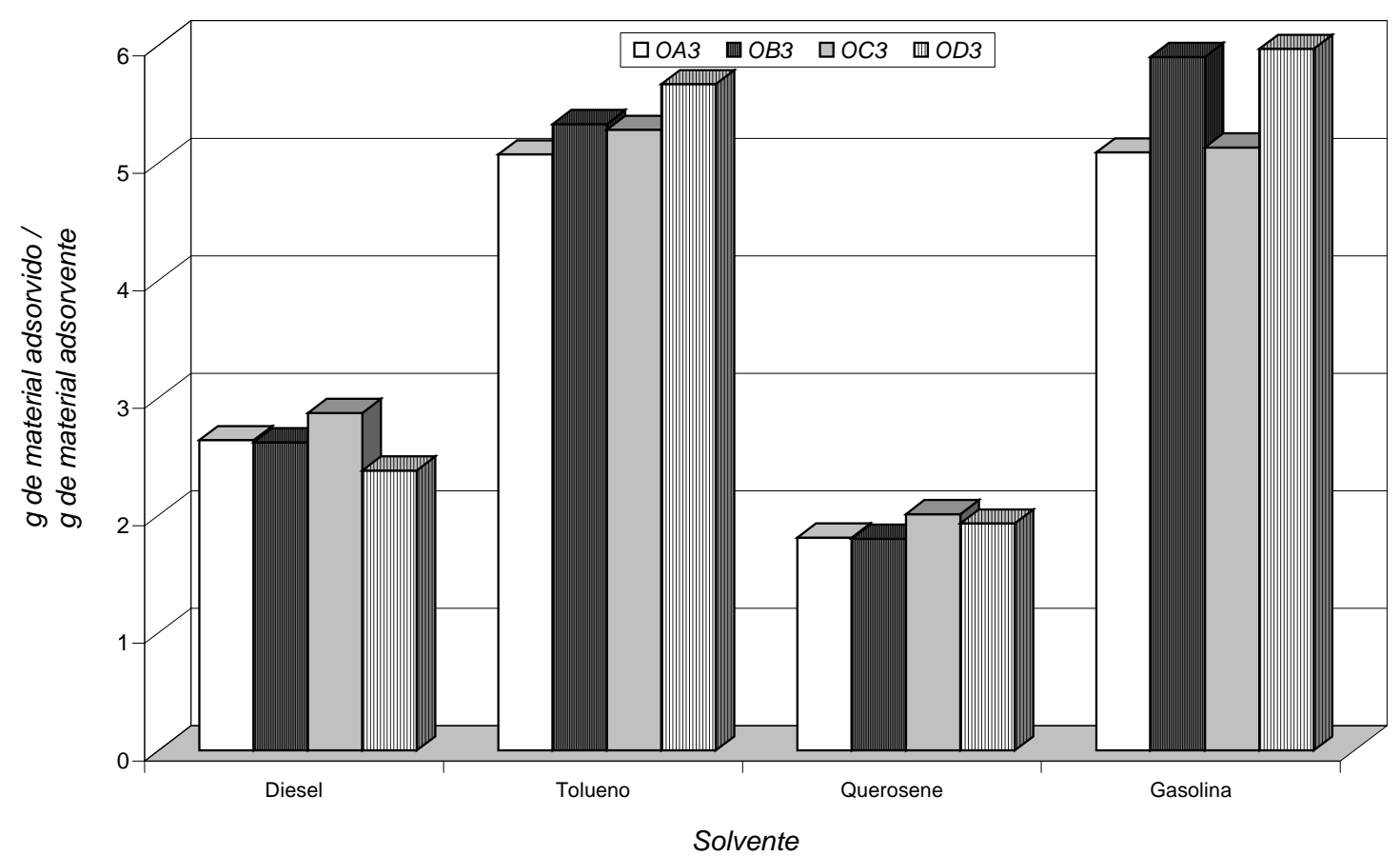

Figura 6.6.3 - Sorção das amostras A, B, C e D tratadas com o sal quaternário 3.

De acordo com os resultados apresentados na Figura 6.6.3, verificamos que:

1) Amostra A sorveu: querosene $<$ diesel $<$ tolueno < gasolina.

2) Amostra B sorveu: querosene $<$ diesel $<$ tolueno < gasolina.

3) Amostra C sorveu: querosene < diesel < gasolina < tolueno.

4) Amostra D sorveu: querosene $<$ diesel $<$ tolueno < gasolina.

Observa-se nestes resultados que todas as amostras, independente do sal utilizado na obtenção das argilas organofílicas, apresentaram comportamento similar na sorção. Observamos ainda, que algumas sorveram melhor gasolina e outras tolueno, porém estes valores foram muito próximos. Este teste apresentou conformidade com o teste de inchamento de Foster, no qual os melhores resultados ficaram nos solventes gasolina e tolueno.

Comportamento similar foi obtido por Pereira [2003], que realizou teste de sorção em diversos solventes orgânicos, como: gasolina, querosene, diesel, etanol, metanol, tolueno, acetona e Varsol (solvente comercial à base de óleos minerais). Verificou os melhores resultados em tolueno e gasolina e os menos favoráveis em querosene e Varsol. 
Ramos Vianna [2005] e Ramos Vianna et al. [2004] realizaram teste de sorção com argilas organofílicas preparadas por métodos tradicionais e adaptados aos tradicionais e verificou que estas apresentaram potencial de uso em uma variedade de aplicações em tecnologias do meio ambiente.

Pereira et al. [2005], preparam argila organofílica a partir de argila esmectítica policatiônica proveniente da Paraíba com objetivo de sorver hidrocarbonetos derivados do petróleo e verificaram que o material obtido apresentou bons resultados de sorção em gasolina e tolueno. 
argilasativaçãoquimicaorganofiliza ãoesmectíticasbentonitasestudoáci adescoramentosorventeshidrocarb
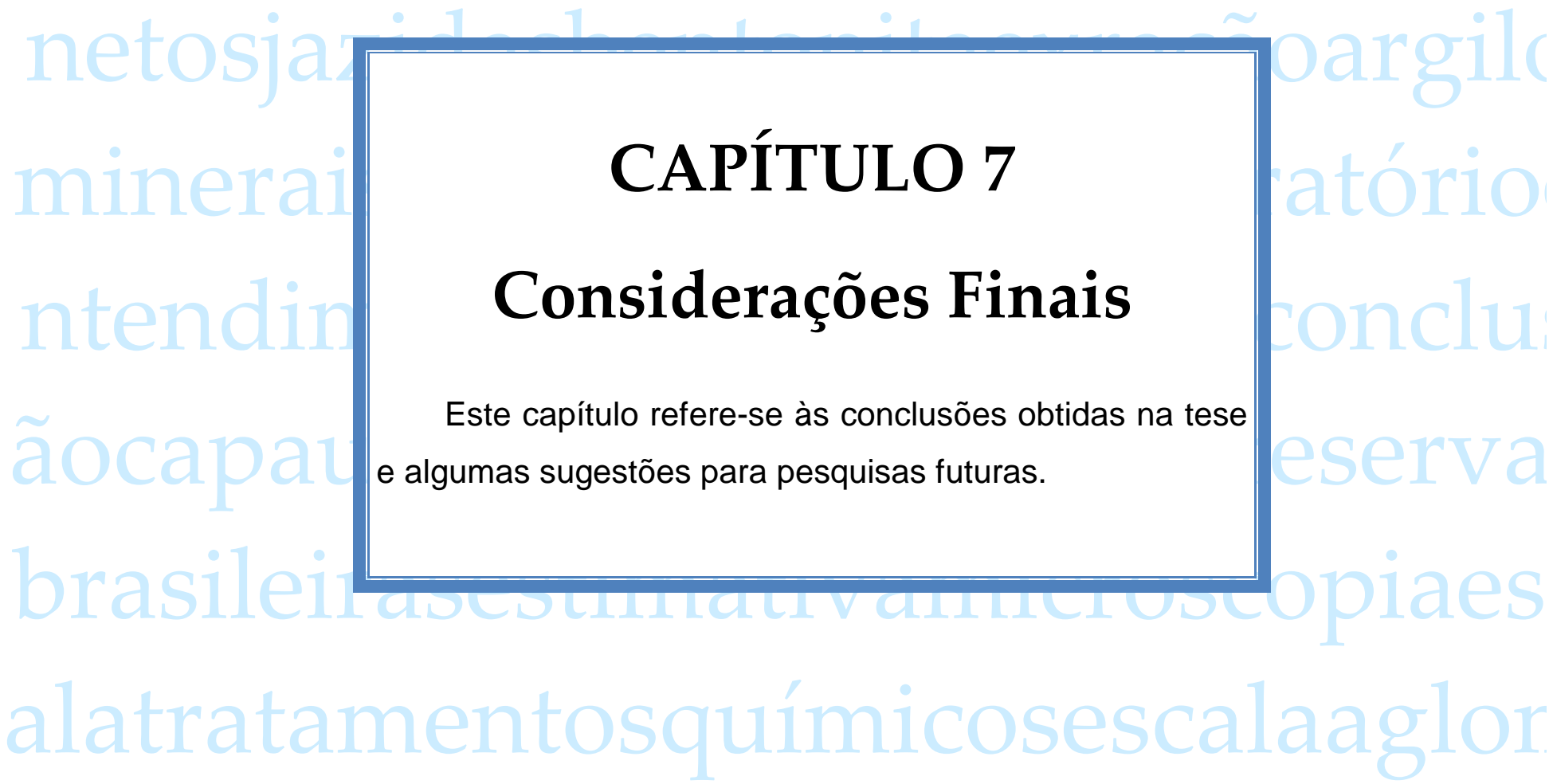
eradoslocalizadasrea çãotempossai. quaternáriosespectroscopiadescora mentoorganofílicastabelasgráficosir etodologiaresultadosa tivaçãob ofer alizaçãoteseartigosespectrofotomet agasolinaclorídricolab oratórioutiliz çãoindústrialcientífico ciên ciab ofeo 


\subsection{Conclusões}

O estudo desenvolvido para realização desta tese, que foi dividida em duas partes: Ativação ácida e obtenção de argilas organofílicas, a partir de argilas do tipo Bofe, provenientes do Estado da Paraíba, nos permite concluir que:

\subsubsection{Argila natural}

1. Observou-se que as amostras utilizadas apresentaram, em sua composição, a predominância do argilomineral esmectítico e que a CTC ficou na faixa apresentada por argilas deste tipo.

2. Os espectros na região do infravermelho apresentam conformidade com os difratogramas de raios- $X$, no qual foram registradas composição referentes às camadas do argilomineral esmectítico.

3. De uma forma geral, de acordo com os difratogramas de raios-X e as curvas espectográficas na região do infravermelho, verifica-se que as quatro amostras são similares, o que indica que mesmo tratando-se de amostras recolhidas em depósitos diferentes, devem pertencer a uma mesma camada geológica.

4. Por análises térmicas, verificou-se perdas de massa na faixa esperada para argilas esmectíticas da região de Boa Vista, Paraíba.

5. Através das micrografias observou-se que as argilas esmectíticas estudadas apresentam tamanho e forma característica de argilas deste grupo. 


\subsubsection{Ativação ácida}

1. A partir dos difratogramas de raios-X e dos espectros na região do infravermelho, observou-se que para os tempos de reação de 1, 2 e 3 horas, usando-se ácido clorídrico, não causou danos aparentes à estrutura do argilomineral.

2. Utilizando-se o mesmo ácido e aumentando-se os tempos de reação para 1 , 2, 3, 4, 5, 6 e 7 dias, observou-se que a estrutura das argilas ficou comprometida, sendo destruída.

3. Para o descoramento de óleo de soja, verificou-se que a amostra natural obteve eficiência muito parecida com as argilas ativadas, sendo que os melhores resultados foram das amostras ativadas com tempo de reação de 1 e 3 horas.

4. As amostras estudadas, na sua forma natural sem ataque ácido, apresentaram poder de descoramento de óleo de soja superior ao de argilas ativadas comerciais de renome internacional, tendo assim comportamento de terras fuller. As amostras apresentam assim amplo potencial de uso como argilas descorantes, sendo que seu custo de processamento deve ser baixo comparado com o das amostras que necessitam ser ativadas com ácidos para adquirir poder descorante.

\subsubsection{Argilas organofílicas}

1. Através das técnicas de difração de raios-X e dos espectros na região do infravermelho, foi possível verificar a efetiva intercalação do cátion do sal quaternário de amônio na estrutura da amostra estudada, independente do sal utilizado. 
2. Não foram observadas diferenças significativas entre as micrografias dos materiais obtidos.

3. Os resultados obtidos indicam que as argilas organofílicas preparadas apresentam alto potencial de uso em fluidos de perfuração à base de óleos, em lubrificantes para altas temperaturas e em diversas indústrias que lidam com solventes similares aos testados.

4. As amostras obtidas apresentaram eficiência na sorção de gasolina e tolueno, tendo assim os materiais obtidos, alto potencial de uso como sorventes de hidrocarbonetos.

5. Os elevados valores de sorção em tolueno e gasolina (entre $5 \mathrm{~g} / \mathrm{g}$ e $8 \mathrm{~g} / \mathrm{g}$ ) dos diversos materiais preparados indicam um alto potencial de uso como sorventes de óleos e hidrocarbonetos e substâncias similares.

\subsection{Sugestões para pesquisas futuras}

Algumas sugestões para pesquisas futuras são:

\subsubsection{Ativação ácida}

1. Verificar o poder descorante das amostras ativadas, nas condições utilizadas nesta tese, em outros óleos vegetais, como milho e mamona.

2. Realizar o estudo de ativação, nas mesmas condições utilizadas nesta tese, utilizando-se o ácido sulfúrico e, com $\mathrm{HCl}$ e $\mathrm{H}_{2} \mathrm{SO}_{4}$ e tempos de reação entre 3 horas e 1 dia. 


\subsubsection{Argilas organofílicas}

1. Utilizar as amostras deste estudo na obtenção de argilas organofílicas a partir de outros sais quaternários, realizando o teste de sorção com os mesmos solventes.

2. Realizar estudo utilizando os sais desta tese em outras amostras de argilas.

3. Estudar a possibilidade do uso destas na obtenção de nanocompósitos poliméricos. 
argilasativaçãoquímica organ otiliza ãoesmectíticasbentonitasestudoácic adescoramentosorventeshidrocarbr

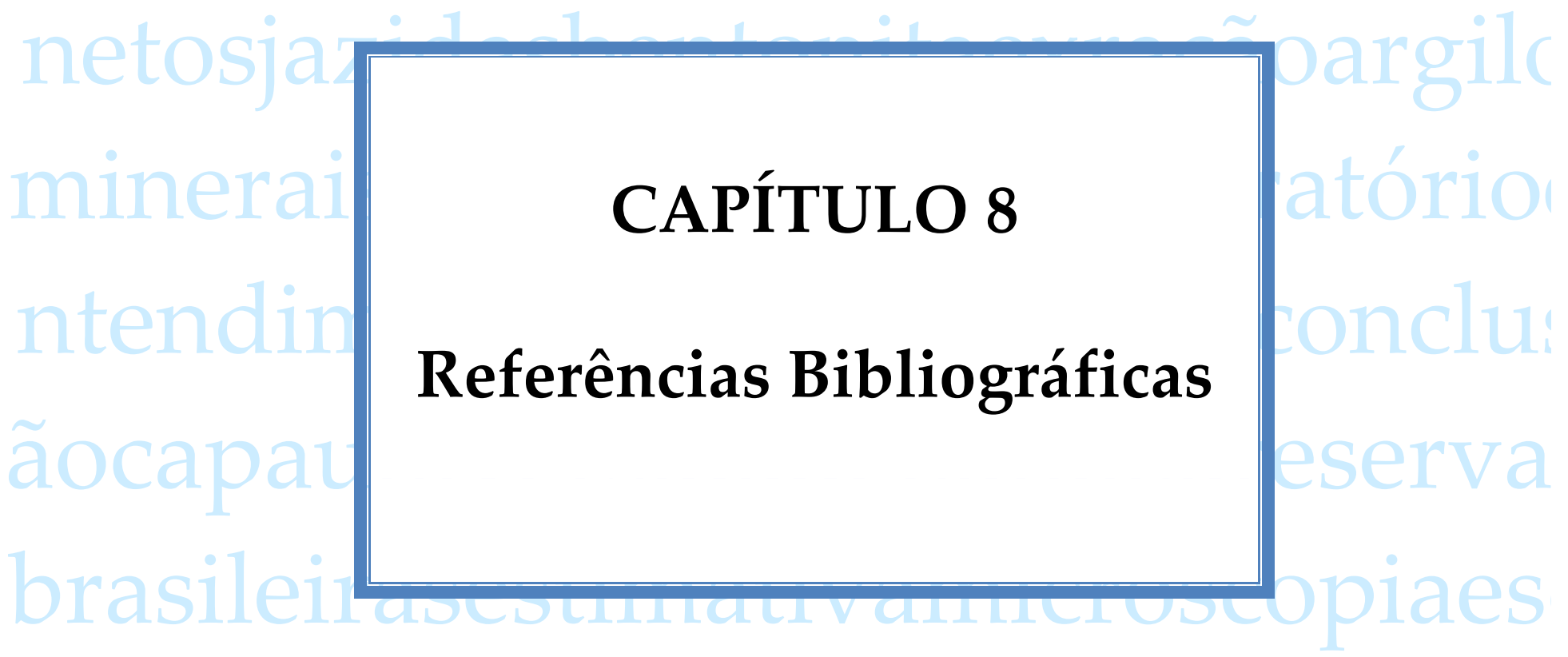

alatratamentosquímicosescalaaglor eradoslocalizadasreaçãotempossaí quaternáriosespectroscopiadescorc mentoorganofílicastabelasgráficosn etodologiaresultadosativaçãobofer alizaçãoteseartigosespectrofotomet: agasolinaclorídricolaboratórioutiliz çãoindústrialcientíficociênciab ofeo ganofílicatoluenodescoramentotérr 


\section{REFERÊNCIAS BIBLIOGRÁFICAS}

ABREU, L. D. V. de. Estudo da pilarização, com alumina, de argilas esmectíticas brasileiras. Dissertação (Mestrado), Departamento de Engenharia Química da Escola Politécnica da Universidade de São Paulo, São Paulo, 135p., 1997.

ABREU, S. F. Recursos minerais do Brasil, Ed. Edgard Blücher, $2^{\underline{a}}$ ed., V. 1, São Paulo-SP, 324p., 1973.

ARROYO, P. A. Caracterização e avaliação de zeólitas Y ultraestáveis contendo zinco. Dissertação (Mestrado), Coordenação dos Programas de Pós-Graduação em Engenharia, Universidade Federal do Rio de Janeiro, 158p., 1992.

BALA, P.; SAMATARAY, B. K.; SRIVASTAVA, S. K. Synthesis and characterization of Na-montmorillonite-alkylammonium intercalation compounds. Materials Research Bulletin, v. 35, p. 1717-1724, 2000.

BARAÚNA, O. S. Argilas esmectíticas do nordeste brasileiro. Anais do II Congresso Brasileiro de Engenharia de Minas, 2, 667-698, 1993.

BOTELHO, K. T. Síntese de argilas organofílicas e sua incorporação em polimerização in situ para obtenção de nanocompósitos antichamas de poliestireno. Dissertação (Mestrado), Departamento de Engenharia Química e Engenharia de Alimentos da Universidade Federal de Santa Catarina, FlorianópolisSC, 68p., 2006.

BOTELHO, K. T.; PEREIRA, K. R. O.; WIEBECK, H.; VALENZUELA DÍAZ, F. R.; SOUZA SANTOS, P. Synthesis and characterization of organophilic clay to use in polystyrene-clay nanocomposite. Program and Proceedings the Polymer Processing Society, $23^{\text {rd }}$ Annual Meeting, 2007.

CHRISTIDIS, G. E.; SCOTT, P. W.; DUNHAM, A. C. Acid activation and bleaching capacity of bentonites from the island of Milos and Chios, Aegean, Greece. Applied Clay Science, v. 12, p. 329-347, 1997.

CLARKE, G. M. Special Clays. Ind. Miner., v. 216, p. 25-51, 1985.

DANA, J. D. Manual de mineralogia. Livros Técnicos e Científicos, Rio de Janeiro, 642p., 1969. 
Departamento Nacional de Produção Mineral (DNPM). Bentonita. Sumário Mineral Brasileiro, 2001.

DOMBROWSKY, T.; HENDERSON, J. Acid activation of montmorillonite: methods, mechanisms and applications. Abstracts of the $11^{\text {th }}$ International Clay Conference, Carleton University, Ottawa, p. A23, 1997.

DWECK, J; BÜCHLER, P. M.; CARTLEDGE, F. K. The effect of different bentonitas on cement hydration during solidification/stabilization of tannery wastes. Journal of Thermal Analysis and Calorimetry, v. 64, p. 1011-1016, 2001.

FRANCA, V. V.; BÜCHLER, P. M. Organoclays as adsorbents of organic compounds in residues. Anais do $12^{\circ}$ Congresso Brasileiro de Engenharia Química (CD-Rom), Porto Alegre-RS, 1998.

GOMES, C. F. Argilas: o que são e para que servem. $1^{\text {a }}$ edição, Fundação Calouste Gulbenkian, Lisboa, 457p., 1988.

GONZAGA, A. C.; SOUSA, B. V. de; PEREIRA, K. R. O.; VALENZUELA DÍAZ, F. R.; NEVES, G. A.; SANTANA, L. N. L.; RODRIGUES, M. G.; Preparação de argila organofílica a partir de bentonitas do Estado da Paraíba. Mens Agitat, v. 2, n. 2, p. 37-42, 2007.

GRIM, R. E. Applied clay mineralogy. New York, McGraw-Hill Book Co., 1962.

GRIM, R. E. Clay mineralogy. McGraw-Hill Book Co., New York, 1953.

GRIM, R. E. Clay mineralogy. McGraw-Hill Book Co., New York, $2^{\text {nd }}$ ed., 1968.

JAYNES, W. F.; BOYD, S. A. Clay mineral type and organic compound sorption by hexadecyltrimethylammonium-exchange clays. Soil Science of American Journal, v. 55, p. 43-48, 1991.

LABA, D. Rheological properties of cosmetics and toiletries. New York: Editora Marcel Deker, 1993.

LAGALY, G. Layer charge heterogeneity in vermiculites. Clays and Clay Minerals, v. 30, p. 215-222, 1982. 
LIRA FILHO, D. P. de. Perfil analítico da bentonita. Ministério das Minas e Energia, Departamento Nacional da Produção Mineral (DNPM), boletim n. 4, 33p., 1973.

MACKENZIE, R. C. The classification and nomenclature of clay minerals. Clays Min. Bull. v. 4, p. 52, 1959.

MOORE, D. M.; REYNOLDS Jr., R. C. X-ray diffraction and the identification and analysis of clay minerals. Oxford University Press, 332p., 1989.

MORGADO, A. F. Caracterização e propriedades tecnológicas de uma argila esmectítica de Santa Catarina. Tese (doutorado), Departamento de Engenharia Química da Escola Politécnica da Universidade de São Paulo, São Paulo-SP, 181p., 1998.

OLIVEIRA, M. L. de. Bentonita. Departamento Nacional de Produção Mineral (DNPM), DNPM/SEDE, p. 41-42. 2004.

PEREIRA, K. R. O. Ativação ácida e preparação de argilas organofílicas partindo-se de argila esmectítica proveniente do Estado da Paraíba. Dissertação (Mestrado), Programa de Pós-Graduação em Engenharia Química da Universidade Federal de Campina Grande, Campina Grande-PB, 92p., 2003.

PEREIRA, K. R. O.; HANNA, R. A.; RAMOS VIANNA, M. M. G.; PINTO, C. A.; RODRIGUES, M. G.; VALENZUELA DÍAZ, F. R. Brazilian organoclays as nanostructured sorbents of petroleum-derived hydrocarbons. Materials Research, v. 8, n. 1, p. 77-80, 2005.

PEREIRA, K. R. O.; KOZIEVITCH, V. de F. J..; RODRIGUES, M. G.; VALENZUELA DÍAZ, F. R. Argila ativada com ácidos clorídrico e sulfúrico para descoramento de óleos de soja e milho. Anais do XV Congresso Brasileiro de Engenharia Química (CD-Rom), Curitiba-PR, 2004.

PEREIRA, K. R. O.; RAMOS VIANNA, M. M. G.; RODRIGUES, M. G.; VALENZUELA DÍAZ, F. R. Adsorção de alguns poluentes orgânicos em argilas organofílicas. Anais do XVI Congresso Brasileiro de Ciências e Engenharia dos Materiais (CDRom), Porto Alegre-RS, 2004.

PEREIRA, K. R. O.; RAMOS VIANNA, M. M. G.; RODRIGUES, M. G.; VALENZUELA DÍAZ, F. R. Comparação no uso de 2 métodos para obtenção de argilas organofílicas. Anais do XV Congresso Brasileiro de Engenharia Química (CD-Rom), Curitiba-PR, 2004. 
PEREIRA, K. R. O.; RODRIGUES, M. G.; VALENZUELA DÍAZ, F. R. Síntese e caracterização de argilas organofílicas: comparação no uso de dois métodos. Revista Eletrônica de Materiais e Processos, v. 2.2, p. 01-08, 2007.

PEREIRA, K. R. O.; SILVA, A. A.; MIYAHARA, R. Y.; RODRIGUES, M. G.; TOFFOLI, S. M.; VALENZUELA DÍAZ, F. R. Estudo das propriedades cerâmicas de argilas paraibanas - Bentonitas Chocolate e Aço I. Anais do 50ํㅡㄹ Congresso Brasileiro de Cerâmica (CD-Rom), Blumenau-SC, p. 01-10, 2006.

PINNAVAIA, T. J; BEAL, G. W. Polymer-Clay Nanocomposites. John Wiley, New York, 2001.

PINTO, C. A. Estabilização por solidificação em cimento do resíduo do curtimento do couro contendo cromo. Dissertação (Mestrado), Departamento de Engenharia Química da Escola Politécnica da Universidade de São Paulo, São Paulo-SP, 90p., 2001.

PRAKASH, K.; JASRA, R. V.; BHAT, T. S. G. Evolution of porosity and surface acidity in montmorillonite clay on acid activation. Ind. Eng. Chem., v. 34, p. 1440-1448, 1995.

PUZZI, D. Abastecimento e armazenagem de grãos. Campinas, Instituto Campineiro de Ensino Agrícola, 603p., 1986.

RAMOS, R. R. Estudo de algumas propriedades reológicas e teores de carbonato e bicarbonato após cura em câmara úmida e autoclave de três argilas esmectíticas tratadas com carbonato de sódio da localidade de bravo, distrito de Boa Vista, município de Campina Grande, Paraíba. Dissertação (Mestrado), Programa de Pós-Graduação em Engenharia Química, Universidade Federal da Paraíba, Campina Grande-PB, 237p. 1985.

RAMOS VIANNA, M. M. G. Desenvolvimento de argilas organofílicas visando a remediação de áreas contaminadas por componentes da gasolina. Tese (Doutorado), Departamento de Engenharia Química da Escola Politécnica da Universidade de São Paulo, São Paulo-SP, 133p., 2005.

RAMOS VIANNA, M. M. G. Estudo em escala de laboratório da adsorção de componentes orgânicos do vinhoto em argila organofílica. Dissertação (Mestrado), Departamento de Engenharia Química da Escola Politécnica da Universidade de São Paulo, São Paulo-SP, 89p., 2001. 
RAMOS VIANNA, M. M. G.; VIEIRA JOSÉ, C. L.; PINTO, C. A.; BÜCHLER, P. M.; VALENZUELA DÍAZ, F. R. Preparação de duas argilas organofílicas visando seu uso como sorventes de hidrocarbonetos. Anais do 46을 Congresso Brasileiro de Cerâmica (CD-Rom), São Paulo-SP, p. 1860-1871, 2002.

RAMOS VIANNA, M. M. G.; PINTO, C. A.; KOZIEVITCH, V. F. J.; PEREIRA, K. R. O.; VALENZUELA DÍAZ, F. R.; DWECK, J.; BÜCHLER, P. M.; Sorption of organoclays in some organic components of gasoline. Anais do XV Congresso Brasileiro de Engenharia Química (CD-Rom), Curitiba-PR, 2004.

RODRIGUES, M. G.; PEREIRA, K. R. O.; VALENZUELA DÍAZ, F. R. Obtenção e caracterização de materiais argilosos quimicamente ativados para utilização em catálise. Cerâmica, n. 52, p. 260-263, 2006.

SHARMASARKAR, S.; JAYNES, W. F.; VANCE, G. F. BTEX sorption by montmorillonite organo-clays: TMPA, ADAM, HDTMA. Water air and soil pollution, v. 119, n. 1-4, p. 257-273, 2000.

SHENG, G. Y.; BOYD, S. A. Relation of water and neutral organic compounds in the interlayers of mixed $\mathrm{Ca}$ /trimethylphenylammonium-smectites. Clays and Clay Minerals, v. 46, p. 10-17, 1998.

SILVA, A. A.; MENEZES, R. R.; RODRIGUES, M. G. F.; PEREIRA, K. R. de O.; OLIVEIRA, A. M. V. Efeito da natureza do ácido $\mathrm{HCl}$ e $\mathrm{H}_{2} \mathrm{SO}_{4}$ na argila esmectítica chocolate, Boa Vista, PB, Brasil, Anais do 46ํㅡㄹ Congresso Brasileiro de Cerâmica (CD-Rom), São Paulo-SP, 2002.

SILVA SANTOS, R. J. da; MARINHO, R. M. M.; PONTES, L. R. A.; SUDÉRIO, V. M. Caracterização da cerâmica vermelha do Triângulo Crajubar, Anais do $45^{\circ}$ Congresso Brasileiro de Cerâmica (CD-Rom), Florianópolis-SC, 2001.

SILVERSTEIN, R. M.; BASSLER, G. C.; MORRILL, T. C. Identificação espectrométrica de compostos orgânicos. Guanabara Koogan S. A., Rio de Janeiro-RJ, 299p., 1989.

SOUZA SANTOS, P. de. Ciência e tecnologia de argilas. Ed. Edgard Blücher Ltda., São Paulo-SP, v. 1, 2ª ed., 408p., 1989.

SOUZA SANTOS, P. de. Ciência e tecnologia de argilas. Ed. Edgard Blücher Ltda., São Paulo-SP, v. 2, 2ª ed., 408p., 1992. 
SOUZA SANTOS, P. de. Ciência e tecnologia de argilas. Ed. Edgard Blücher Ltda., São Paulo-SP, v. 3, 2ª ed., 1992.

SOUZA SANTOS, P. de. Tecnologia de argilas, aplicada às argilas brasileiras, Ed. Edgard Blücher Ltda., São Paulo-SP, v. 1, 340p., 1975.

SOUZA SANTOS, P. de. Tecnologia de argilas, aplicada às argilas brasileiras, Ed. Edgard Blücher Ltda., São Paulo-SP, v. 3, 1975.

SOUZA SANTOS, P. de. Tecnologia de argilas. Ed. Edgard Blücher Ltda., São Paulo-SP, v. 2, 1975.

Standard Test Method for Sorbent Performance of Adsorbents - Designation: F72699.

Standard Methods of Testing Sorbent Performance of Absorbents - Designation: F716-82 (Reapproved 1993).

TATUM, J. P. Industrial application of surfactants. Edited by O. R. Karsa, Royal Society of Chemistry, London, 1987.

TKAC, P.; KOMADEL, D. M. Acid treated montmorillonites: a study ${ }^{28} \mathrm{Si}$ and ${ }^{27} \mathbf{A l}$, MAS-NMR. Clay Minerals, v. 29, p. 11-19, 1994.

ULLMANN'S. Encyclopedia of industrial chemistry. v. A7, $5^{\text {th }}$ ed., 1986.

VALENZUELA DÍAZ, F. R. Obtenção de argilas organofílicas partindo-se de argila esmectítica e do sal quaternário de amônio "ARQUAD 2HT-75", Anais do $43^{\circ}$ Congresso Brasileiro de Cerâmica (CD-Rom), Florianópolis-SC, p. 43201-43213, 1999.

VALENZUELA DÍAZ, F. R. Preparação a nível de laboratório de algumas argilas esmectíticas organofílicas. Tese (Doutorado), Departamento de Engenharia Química da Escola Politécnica da Universidade de São Paulo, São Paulo-SP, 256p., 1994.

VALENZUELA DÍAZ, F. R. Preparation of organophilic clays from a Brazilian smectitic clay. Key Engineering Materials, v. 189-191, p. 203-207, 2001. 
VALENZUELA DÍAZ, F. R.; MOURÃO, W. S. B.; VIEIRA COELHO, A. C.; SOUZA SANTOS, $P$. de. Obtenção de algumas argilas organofílicas; influência da concentração das dispersões aquosas de partida. Anais do $12^{\circ}$ Congresso Brasileiro de Engenharia Química (CD-Rom), Porto Alegre-RS, 1998.

VALENZUELA DÍAZ, F. R.; SOUZA SANTOS, P. de. Caracterização de amostras comerciais de argilas ativadas com ácidos. Parte 1. DRX e descoramento de óleo de soja. Anais do 44ํㅡㄹ Congresso Brasileiro de Cerâmica (CD-Rom), São Pedro-SP, p. 04501-04510, 2000.

VALENZUELA DÍAZ, F. R.; SOUZA SANTOS, P. Efeito do ataque ácido, da ordem de adição dos reagentes e do tipo de cátion interlamelar em esmectitas $I$. Distribuição de poros por porosimetria de mercúrio. Cerâmica, 37, p. 70-75, anexo 29, 1991.

VALENZUELA DÍAZ, F. R.; SOUZA SANTOS, P. de. Studies on the acid activation of Brazilian smectitic clays. Química Nova, v. 24, n.ำ 3, p. 345-353, 2001.

VALENZUELA DÍAZ, F. R.; SOUZA SANTOS, P. de; SOUZA SANTOS, H. A importância das argilas industriais brasileiras. Química Industrial, v. 42, p. 33-37, 1992.a.

VALENZUELA DÍAZ, F. R.; SOUZA SANTOS, P. de; SOUZA SANTOS, H. A importância das argilas industriais brasileiras. Química Industrial, v. 44, p. 31-37, 1992.b.

VIEIRA JOSÉ, C. L.; PINTO, C. A.; VALENZUELA DÍAZ, F. R.; BÜCHLER, P. M. Sintetização de argilas organofílicas visando seu uso no controle ambiental de resíduos de fenol. Anais do 46ํㅡㄹ Congresso Brasileiro de Cerâmica (CD-Rom), São Paulo-SP, p. 1685-1695, 2002.

YARIV, S. The role of charcoal on DTA curves of organo-clay complexes: an overview. Applied Clay Science, v. 24, p. 225-236, 2004.

YARIV, S.; CROSS, H. Organo-clay complexes and interaction. 1ed. v.1, Nova lorque, Marcel Dekker, Inc., 2002.

ZHANG, W, A.; CHEN, D. Z; XU, H. Y.; SHEN, X. F.; FANG, Y. E. Influence of four different types of organophilic clay on the morphology and thermal properties of polystyrene/clay nanocomposites prepared by using the $\square$-ray irradiation technique. European Polymer Journal, v. 39, p. 2323-2328, 2003. 
ZHANG, Z. Z.; SPARKS, D. L.; SCRIVNER, N. C. Sorption and desorption of quaternary amine cations on clays. Environmental Science \& Technology, v. 27, n. 8, p. 1625-1631, 1993. 